\title{
DWPF WASTE FORM COMPLIANCE PLAN (DRAFT REVISION) (U)
}

\author{
by \\ M. J. Plodinec and S. L. Marra \\ Westinghouse Savannah River Company \\ Savannah River Site \\ Aiken, South Carolina 29808
}

\section{DISCLAIMER}

This is a Technical Report

\begin{abstract}
This report was prepared as an account of work sponsored by an agency of the United Stetes Government. Neither the United States Government nor any agency thereof, nor any of their employees, makes any warranty, express or implied, or assumes any legal liability or responsibility for the accuracy, completeness, or usefulness of any information, apparatus, product, or process disclosed, or represents that its use would not infringe privately owned rights. Reference herein to any specific commercial product, process, or service by trade name, trademark, manufacturer, or otherwise does not necessarily constitute or imply its endorsement, recommendation, or favoring by the United States Government or any agency thereof. The views and opinions of authors expressed herein do not necessarily state or reflect those of the United States Government or any agency thereof.
\end{abstract}

This report was prepared in connection with work done under Contract No. DE-AC09-89SR 18035 with the U.S. Department of Energy. By acceptance of this report the publisher and/or recipient acknowledges the U.S. Government's right to retain a nonexclusive, royalty-free license in and to any copyright covering this report, along with the right to reproduce and to authorize others to reproduce all or part of the copyrighted report.

\section{MASTER}




\section{Waste Form Compliance Plan}

for the DWPF -

Revision 1

Draft for the Technical Review Group 
PART TITLE: INTRODUCTION

NSRC- SNA $4-5$

Part 1

Item 100

Page 1 of 3

Date: $7 / 9$ :

Revision $1 \mathrm{H}$

ITEM TITLE: WASTE ACCEPTANCE PROCESS

The Department of Energy currently has over 100 million liters of high-level radioactive waste in storage at the Savannah River site (SRS). These wastes, which are generated during the production of nuclear materials for defense needs, have been stored as alkaline slurries in large carbon-steel tanks since the mid-1950's. This has proven to be a safe and effective way of isolating the hazardous radionuclides from the environment.

However, while storage of liquid waste has been safe and effective, it has required continuous monitoring, and periodic construction and retirement of waste tanks. In the late 1970's, the Department of Energy recognized that there were significant safety and cost advantages associated with immobilizing the high-level waste in a stable solid form. Several alternative waste forms were evaluated in terms of product quality and reliability of fabrication. This evaluation led to a decision to build the Defense waste Processing Eacility (DWPE) at SRS to convert the easily dispersed liquid waste to borosilicate glass. In accordance with the NEPA (National Environmental Policy Act) process, an Environmental. Impact statement was prepared for the facility, as well. as an Environmental Assessment of the alternative waste forms, and issuance of a Record of Decision (in December, 1982) on the waste form. This Record of Decision was endorsed by the Environmental Protection Agency, several independent review groups, and the $\mathrm{Nu}-$ clear Regulatory Commission (NRC).

The Nuclear waste Policy Act of 1982 mandated that all high-level waste would be sent to a federal repository for disposal. In 1985, the president ratified a decision made by the secretary of Energy to send defense high-level waste, including the canistered wast a forms from the DWPE, to a civilian repository. The Department of Energy, recognizing that start-up of the DWPE would considerably precede licensing of a repository, instituted a waste Acceptance Process to ensure that these canistered waste forms would be acceptable for eventual disposal at a federal repository.

As part of the Waste Acceptance Process, the Department of Energy's Office of Civilian Radioactive Waste Management created the Waste Acceptance Committee (WAC) which was responsible for defining the requirements which canistered waste forms would have to meet to be compatible with any of the media then being considered 
WSRC $-\operatorname{SN4} 4-5$

Part 1

Item 100

Eage 2 of 3

Date: $7 / 91$

PART TITLE: INTRODUCTION

Revision $1 \mathrm{~A}$

ITEM TITLE: WASTE ACCEPTANCE PROCESS

for the first repository. The WAC, with representatives from the repository projects and the waste form producers, developed the Waste Acceptance Preliminary Specifications (WAPS) which identified these requirements. The specifications are periodically re-vised as the repository program proceeds, and as the DWPE process is further optimized. It is anticipated that the specifications will not become final until after non-radioactive testing is completed in the DWPE.

The WAPS are divided into four sections dealing with the waste form (borosilicate glass), the canister, the canistered waste form, and quality assurance of waste Acceptance Process activities. The DWPE is required to document its compliance with the WAPS in the Waste Form Compliance Plan (WCP), the Waste Form Qualification Report (WQR), in the Production Records, and in the Shipping and Storage Records. The current version of the WAPS is contained in Appendix 1.100.1, for reference.

The Waste Form Compliance Blan (WCP) provides general information about the DWPE process and product, and a detailed description of the methods and programs by which the DWPF will demonstrate compliance with each specification in the WAPS.

The Waste Form Qualification Report (WQR) is a compilation of the results of those testing and analysis programs identified in the WCP. The common objective of those programs is to confirm the DWPE's ability to produce an acceptable product. Thus, the WQR provides detailed evidence that the DWPE product will be in compliance with each specification, and thereby compatible with candidate repository environments. Parts of the WQR will be used to gain approval for startup of the DWPE, and may be used in licensing of a repository containing DWPE canistered waste forms.

The WQR is being prepared in a phased manner. Initial draft sections, primarily those summarizing research and development activities performed for the DWPE by the Savannah River Laboratory (SRL), are being issued for review and comment as soon as they are prepared. A first draft addressing each of the WAPS is currently scheduled for completion prior to the initiation of non-radioactive testing in the DWPE. At the completion of the non-radioactive testing program, and before the initiation of radioactive op- 
PART TITLE: INTRODUCTION

WSRC-SW 4-6

Part 1

Item 100

Page 3 of 3

Late: $7 / 31$

Revision $1 \mathrm{~A}$

ITEM TITLE: WASTE ACCEPTANCE PROCESS

erations, the DWPE will issue a dra:t WQR summarizing all of the information available, including the information from the nonradioactive testing in the DWPF. However, it is anticipated that some parts of the WQR (for example, a report on level detection by gamma emission from the canister) will not be completed until after the start of radioactive operations. Thus, work on the WQR will continue even after facility startup.

The Production Records, and the Shipping and storage Records, are documents that describe the contents and characteristics of specific individual canistered waste forms. Prepared and maintained by the DWPE, these documents will summarize the entire production history of each canistered waste form, including canister fabrication, canister filling with glass, sealing of the filled canister, storage of the canistered waste form at SRS, and loading into a shipping cask. Thus, these records will be the primary documentary evidence of the acceptability of individual canistered waste forms. 
WSRC-STS-b

Part 1

Item 200

Page 1 oE 1:

Date: $8 / 9$ :

Revision 19

\section{PART TITLE: INTRODUCTION}

ITEM TITLE: OVERVIEW OE THE WASTE FORM COMPLIANCE PLAN

According to the Waste Acceptance Preliminary Specifications (see Appendix 1.100.1), this document, "he DWPE Waste Form Compliance Plan (WCP), is to provide a detailed description of the methods by which the DWPE will demonstrate compliance with each specification in the WAPS.

The overall strategy for complying with the WAPS is to assure the quality of the product by a combination of component specifications and process controls. Many of the specifications in the WAPS require that the canister and waste form be well-characterized before the DWPE begins production of actual waste forms. The research and development activities related to characterization of the waste form and the canister are described in the WCP. other specifications address canistered waste forms produced during radioactive operation. The strategy for compliance with these specifications is to demonstrate that the DWPE product will be acceptable over the range of anticipated chemical compositions and operating conditions.

The WCP has been prepared for the DWPE by the Savannah River Laboratory (SRL). The WCP is reviewed and accepted by the DWPE, before issue. The WCP is issued and maintained by the DWRE, and revised as necessary. The first version of the WCP was prepared in 1986, and has been updated periodically since that time. The previous (3/90) version of the WCP was the first to undergo independent technical review by DOE's Technical Review Group (TRG). This group, with joint sponsorship and participation by DOE's offices of Civilian Radioactive Waste Management, and Environmental Restoration and Waste Management, is responsible for independently assessing the technical adequacy of the WCP, and other waste Acceptance process documeits.

The WCP is organized in a Part and Item format to facilitate review of individual sections. The revision number found in the heading of each page indicates the revision number of that particular item. The Table uf Contents is revised each time any other section is revised. The revision number of the Table of contents constitutes the revision number of the entire document.

Eollowing this Introduction, Part 2 briefly describes the DWPE process. The remaining parts are organized around the four sec- 
WSRC-SW $4-5$

Part 1

Item 200

Page 2 of 11

Date: $8 / 91$

Revision $1 \mathrm{~B}$

PART TITLE: INTRODUCTION

ITEM TITLE: OVERVIEW OF THE WASTE EORM COMPLIANCE PLAN

tions of the waste Acceptance Preliminary Specifications: waste form, canister, canistered waste form, and quality assurance. Within each part, each WAPS specification is addressed as a separate item. For each specification, the statement of requirements from the WAPS and the corresponding rationale are presented first in bold-face type, verbatim. This is followed by sections detailing the compliance strategy, implementation of that strategy, and required documentation.

The compliance strategy section is a general description of the strategy, or management plan, to demonstrate compliance with the particular specification. This is supplemented by a logic diagram which depicts the plan of action to satisfy the specification. The set of activities depicted in the diagrams constitutes the set of Waste Acceptance Process activities for that specification. The intended mode of documentation of the planned activities is indicated on the diagram by the symbols used. A key is provided in Figure 1.200.1. The organization assigned zesponsibility for completing each task on the diagram is also indicated. The DWPE has overall responsibility for the implementation of the waste Eorm Compliance Plan.

The documentation section briefly summarizes how compliance with the specification will be documented. The collection of these documentation sections constitutes a definition of the content of the WQR, the Production Records, and the Shipping and Storage Records. Appendix 1.200 .1 contains a description of the content of the Production Records, and Appendix 1.200 .2 contains a description of the content of the Shipping and Storage Records, as required by the WAPS.

A plan for a comprehensive test program has been developed, covering all aspects of facility startup. One of the primary objectives of the plan is to demonstrate that the facility will be able to satisfy the WAPS. The testing program, called the DWPE startup Test Program, requires development of detailed test plans and procedures for each of the activities. The test plans and procedures are reviewed and approved by a Joint Test Group (JTG), who ensure that the tests to be performed will meet requirements, in a technically defensible manner. The Joint Test Group has representatives from the facility's startup, technical, quality, production, 


WSRC-SW4-5
Part 1
Item 200
Eage 3 of 11
Date: $8 / 91$
Revision 1B

PART TITLE: INTRODUCTION

ITEM TITLE: OVERVIEW OF THE WASTE EORM COMPLIANCE PLAN

and works engineering organizations, as well as from the project Management organization (design function), and SRL (technical bases). The Department of Energy also has full membership on the JTG.

After performance of each test, the JTG will review the test results for technical correctness. The tests to be carried out as part of the DWPE Startup Test Program are identified in Table' 1.200.1. The table highlights those which will provide the detailed evidence of the DWPE's ability to comply with the WAPS. These results will be included in the Waste Form Qualification Report.

Those portions of the DWPE Startup Test Program which will be carried out before radioactive operations begin, and which will demonstrate integrated operation of the facility to produce an acceptable product are called the DWPF Qualification Runs. The Qualification Runs will be of great importance for demonstrating compliance, because during this period the methods and control strategies for DWPF operation will be implemented and tested. A summary of DWPE Qualification Runs activities relevant to the raste Acceptance Process is included as Appendix 1.200.3.

In general, precise identification of some of the activities necessary to demonstrate compliance with a given specification will depend on the results of previous actions. It will be the responsibility of the organization assigned to carry out any task in the WCP to identify further actions for each specification, and to determine whether the results of the task necessitate changes in the compliance strategy (see Part 6, Item 200). SRS-DWPE (with SRL's assistance) will assign responsibilities for these new tasks as they are identified.

As recognized in the Introduction of the Waste Acceptance Preliminary specifications, some individual canistered waste forms may not comply with the specifications in every respect. For these cases, DWPE will identify non-conformances and propose a course of action to allow final disposal. This will be submitted to DOESavannah River Operations office (DOE-SR) for review, as outlined in Part 6, Item 300. DOE-SR is responsible for development of procedures governing communications with, and review by, other organizations in DOE and/or other government organizations. It is 


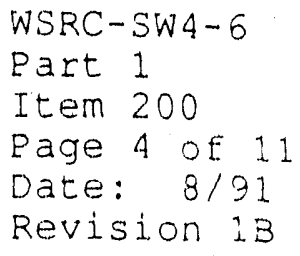

PART TITLE: INTRODUCTION

ITEM TITLE: OVERVIEN OE THE WASTE EORM COMPLIANCE PLAN

anticipated ti.it they will gain the consent of other affected organizations before approving proposed dispositions of non-conforming canistered waste forms.

It is also anticipated that the WCP may require revision after approval by DOE-SR, for example when the preliminary specifications become more finalized, or when significant DWPE process changes are made. Revisions will be made as necessary to the appropriato Item of the WCP and submitted to DOE-SR for review, as outlined in Part 6, Item 200. DOE-SR is responsible for development of procedures governing communications with, and review by, other organizations within DOE, and/or other government organizations. 


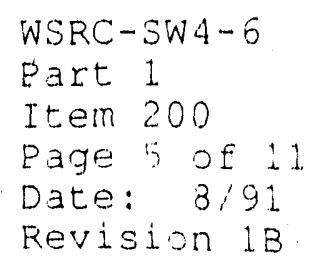

Table 1.200.1 DWPE Startup Test Program - Test Index

Tests which have significant Waste Acceptance Process components are indicated in boldface.

Test Number
DWPE-EA-01.0
DWIE-EA-02.0
DWPE-EA-03.0
DWPE-EA-04.0
DWPE-EA-05.0
DWPE-EA-06.0
DWPE-EA-07.0
DWPE-EA-08.0
DWPE-EA-09.0
DWPE-EA-10.0
DWPE-EA-11.0
DWPE-EA-12.0

DWPF $-F A-13.0$

DWPF-WP -14.0
Test Title

Shielding Integrity

HVAC Testing

Emergency Power Supply T'esting

Process Vessels Erosion/Corrosion Studies

Melter Erosion Study

Automation Software Eunctional Testing

integrated Distributed Control system Test

Integrated Operation with Water

HEME/HEPA Dissolution Test

MFT Start-up with Simulated Feed

Melter Start-up

\section{Inner Canister Closure, Repair, Leak Testing}

During this test, the Inner Canister Closure process will be demonstrated, including formation of the seal, testing of the seal, and the process for forming a repair seal.

Melter Characterization with Composite reed

The primary purpose of this test is to flush the melter, in preparation for the start of the Qualification Runs. The last three canisters produced will be extensively characterized to provide a baseline for the next campaign.

\section{Malter Characterization with Doped Feed}

This test will accomplish two purposes. Eirst, it will provide data which will allow the DWPF to characterize the flow of material rough the melter for normal small changes in feed composition. A non-radioactive dopant will be added to the feed and its in-growth in the glass product followed. Second, the results of this test will demonstrate the DWPF's ability to maintain a consistent product 
WSRC-SW $4-5$

Part 1

Item. 200

Page 6 of 11

Date: $8 / 91$

Revision $1 \mathrm{~B}$

Table 1.200.1 DWPE startup Test Program - Test Index (CONTINUED). Tests which have significant. Waste Acceptance Process components are indicated in boldface.

DWPF-WP -15.0

- during normal small changes in feed composition. This test will also provide canisters for the testing required to meet specifications 2.2 , and 3.1 3.5 of the WAPS.

\section{Melter Chajacterization with Low Viscosity Feed}

This test will accomplish two purposes. First, it will provide data which will allow the DWPE to characterize the flow of material through the melter for large changes in feed composition, which lead to low glass viscosity and high glass density. A simulated Purex waste will be used as the feed and its in-growth in the glass product followed. second, the results of this test will demonstrate the DWPF's ability to maintain a consistent product during large changes in feed composition, which lead to low glass viscosity and high glass density. This test will also provide canisters for the testing required to meet specifications 2.2 , and 3.1 3.5 of the WAPS. During this campaign one of the canisters will be filled through the melter drain valve (DWPE-EA-43).

DWPE-WP-16.0 Melter Characterization with High Viscosity Feed

This test will accomplish two purposes. First, it will provide data which will allow the DWPE to characterize the flow of material through the melter for large changes in feed composition, which lead to high glass viscosity and low glass density. A simulated HM waste will be used as the feed and its in-growth in the glass product followed. Second, the results of this test will demonstrate the DWPE's ability to maintain a consistent product during large changes in feed composition, which lead to high glass viscosity and low glass density. This test will also provide canisters for the testing required to meet specifications 2.2 , and 3.1 3.5 of the WAPS. During this campaign part of one of the canisters will be filled through the melter drain valve (DWPF-EA-43). 


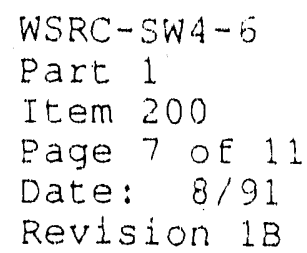

Table.1.200.1 DWPE Startup Test Program - Test Index (CONTINUED). Tests which have significant Waste Acceptance Process components are indicated in boldface.

DWPF - WP -17.0

\section{Melter Characterization with Mercury in Initial} Fead

This test will accomplish three purposes. Eirst, it wlll provide data which will allow the DWPF to characterize the flow of material through the melter for large changes in feed composition, going from high glass viscosity and low glass density to the levels of these properties expected for the initial feed to the DWPE. A simulated Batch 1 waste will be used as the reed and its in-growth in the glass product followed. Second, the results of this test will demonstrate the DWPE's ability to maintain a consistent product during large changes in feed composition, going from high glass viscosity and low glass density to the levels of these properties expected for the initial feed to the DWPE. Third, this test will prepare the facility to begin radioactive operations. This test will also provide canisters for the testing required to. meet specifications 2.2, and 3.1-3.5 of the WAPS. During this campaign part of one of the canisters will be filled through the melter drain valve (DWPE-EA-43).

DWPE-FA-18.0 Melter Characterization with Radioactive Spike

DWPF $-W P-19.0$ Remote Process Sampling Test

During this test, the precision and accuracy of the DWPF sampling and analytical systems for determination of the chemical composition will be characterized.

DWPE-FA-20.0

\section{Transition to Radioactive Operation}

During this test, the DWPE will begin introducing waste from the SRS Tank Earms into the facility, in a controlled manner. The precision and accuracy of the determination of the radionuclide inventory will be determined.

DWPF-WP-21.0

\section{Canister Free volume}

During this test, both the gamma and neutron level 


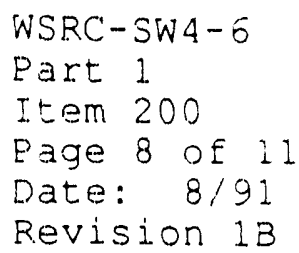

Table 1.200.1 DWEE Startup Test Program - Test Index (CONTINUED). Tests which have significant Waste Acceptance Process components are indicated in boldface.

DWPE $-W P-22.0$

DWPE-WP $-23,0$

DWPE $-W P-24.0$

DWPE-VN-25.0 detection systems will be calibrated and tested. The neutron system will be used routinely throughout the Qualification Runs, the gamma system will. not be tested until gamma-emitting material is introduced into the facility (DWPE-EA-20).

\section{Canister rree Liguid and Pressure}

Canisters filled throughout the Qualification Runs will be sampled to determine whether they contain any foreign materials, especially liquids, and to determine the internal pressure after canister closure.

\section{Canister Temperature Profile Measurement}

During this test, canister cooling temperatures will be measured under several conaitions:

- canisters filled on the melter pour turntable according to reference conditions.

- canisters filled on the melter pour turntable according to reference conditions, and then placed into insulated storage (simulating a likely process upset.).

- canisters filled on the drain turntable according to reference conditions.

In addition, the temperature measurement system of the Glass Waste Storage Building will also be measured.

\section{Canister Welding Párametric study}

The purpose of this test is to develop the envelope of cperating parameters (force, current, time) for the DWPE welder. A statistical experimental design approach will be used to define an operating win-dow. Welds will be characterized according to their leak rates, burst strengths, and microstructures.

\section{Canistar Bandling a Decontamination Systems}

The decontamination process and its controls will 


$$
\begin{aligned}
& \text { WSRC-SW4-6 } \\
& \text { Part } 1 \\
& \text { Item } 200 \\
& \text { Page } 9 \text { of } 11 \\
& \text { Date: } 8 / 91 \\
& \text { Revision 1B }
\end{aligned}
$$
Table 1.200.1 DWPE Startup Test Zrogram - Test Inde:: (CONTINUED). Tests which have significant Waste Acceptance Pro- cess components are indicated in boldface.

$\begin{array}{ll}\text { DWPE-VN-26.0 } & \text { Main Process Cell Crane \& Controls } \\ \text { DWPE-VN-27.0 } & \text { DWTT \& Waste Transfer Eacilities } \\ \text { DWPE-VN-28.0 } & \text { Chemical Waste Treatment \& Catch Tanks } \\ \text { DWPE-EA-29.0 } & \text { Cold Chemical Feeds } \\ \text { DWPE-EA-30.0 } & \text { Process Vessel Vent system }\end{array}$

\section{DWPE-VN-31.0 Canister Transport \& Storage}

As part of this test, measurements of weights and overall dimensions of filled canisters from several of the Qualification Runs will be performed.

DWEE-VN-32.0 Melter Electrical systems

\section{DWPE-FA-33.0 Welder Systems}

This test will demonstrate the ability of the DWPF to routinely produce acceptable welds by operating within the envelope of conditions identified as part of DWPE-WP-24. The repair welding process will also be demonstrated.

DWPE-VN-34.0 Compressed Air Systems

DWPE-EA-35.0 SRAT Operation

DWPE-TA-36.0 SME Operation

As part of this test, control of the composition of the feed using the product Composition Control. System will be demonstrated.

DWPE-FA-37.0 Precipitate Process Operation

DWPE-FA-38.0 Off-Gas System Operation

DWPE-WP-39.0 Glass Sampling Test

This process will demonstrate the ability of the DWPE to r utinely take glass samples from the stream of nolten glass entering the canister. In addition, the ability of SRI to characterize those samples for the DWPF will also be demonstrated. 


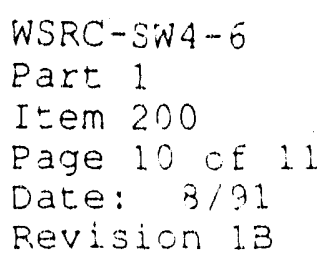

Tabie 1.200.1 DWPE Startup Test Program - Test Index (CONTINUEC). Tests which have significant waste Acceptance Process components are indicated in boldface.

DWPE-VN-40.0

\section{Process Information Management System}

As a part of this test, the DWPE will demonstrate the ability to collect and archive the detailed records of glass production. The ability to gerierate the Production Records will also be demonstrated.

DWPE-VN-41.0 Fire \& Explosion Detection and Protection System(S)

\section{DWPE-FA-42.0 Glass Removal from Canister}

This test will demonstrate the ability of the DWPE to remove any glass adhering to the outside of the canister after filling.

\section{DWPF-EA-43.0 Melter Drain Valve Testing}

This test will demonstrate the DWPE's ability to fill a canister through the melter drain valve. The temperature profile of such canisters will be determined as part of DWPE-WP-23.

DWPE-EA-44.0 HVAC - EOS, Control, Analytical Facilities and Computer Rooms

DWPE-VN-45.0 Electric System Distribution Test 


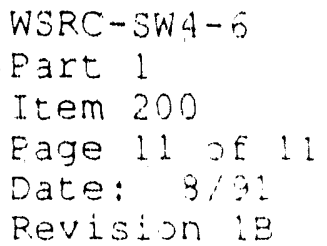

Elgure 1.200 .1 Symbol key for logic diagrams
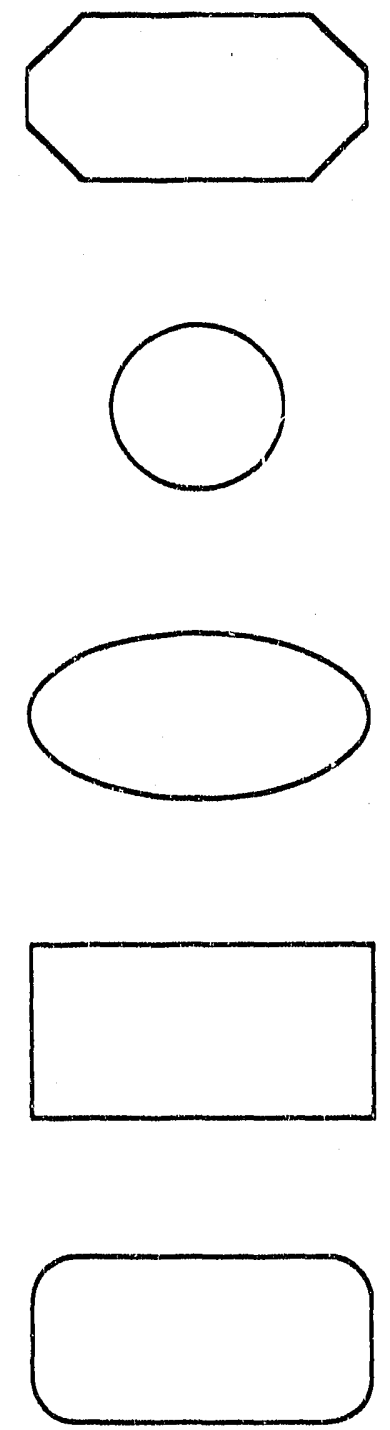

Tasks to be documented in the Waste Eorm Qualification Report.

DWPE HOt

Tasks to be documented in the Production Records.

Tasks following DWPE Hot Startup to be documented in the shipping and storage Records

All other Waste Acceptance Process tasks. 
PART TITLE: INTRODUCTION

ITEM TITLE: GLOSSARY

\section{Acauracy}

As used in the Waste Form Compliance Plan (WCP), accurac' $y^{\prime}$ refers to the ability of a measurement system to reproduce the value of a known standard. The difference between the mean of a number of measurements of a standard, and the accepted value of the measurement for that standard is a measure of the accuracy.

Batahes (see Eigure 1.300.1)

\section{Rrecess Batch}

A portion of the macro-batch that passes through each process vessel; its composition changes because of heels in the tanks. Approximately 30 process batches comprise a macrobatch. The vitrification process is controlled at this level.

\section{Macro-batch}

In the SRS Tank Farm, the feed to the DWPF will remain relatively constant for extended periods of time. The sludge portion of the waste will change every two to three years, while the soluble waste will change every four months. Thus, the feed from the Tank Farm to the DWPE will be relatively constant over a period of about four months at a time. This constant feed to the DWPE constitutes a macro-batch. A macro-batch will yield $\sim 120$ canisters.

\section{MET (Maltar Faed Tank) Batch}

The contents of the Melter Feed Tank constitute an MFT batch. This includes the material transferred from the SME and the heel that was already in the MET. Therefore, the composition of the MET batch may differ slightly from the SME batch and it has a variable volume. The $\mathrm{MFT}$ ? latch is sampled for reporting purposes. One MET batch wili yield an average of four canisters.

\section{Rrecipitate Batch}




WSRC-3WA-5
Part 1
Item 300
Page 2
Date: $8 / 9$
Revision :

PART TITLE: INTRODUCTION

ITEM TITLE: GLOSSARY

The precipitate is prepared in the tank farm for delivery to the DWPE in 1,000,000 gallon batches. For Tank Earm processing purposes, $1 / 6$ of this batch will be delivered to the D'NPE -every 4 months (flowsheet rate) to make up the macrobatch. The 1/6 of the batch sent to the DWPE is replaced to keep the precipitate batch in the tank farm at 1,000,000 gallons; therefore, the composition of the precipitate will change very slowly even from macro-batch lo macro-batch.

\section{Sludge Batch}

The sludge is prepared in the tank farm for delivery to the DWPE in 700,000 gallon batches. This sludge batch will supply the DWPE with material for two to three years.

\section{SMg (Slurey Mix Evaporator) Batch}

The contents of the Slurry Mix Evaporator (SME) constitute a SME batch. This includes the material transferred from the SRAT as well as the heel remaining in the SME. The SME is the point where DWPE will exercise primary control of the glass product.

\section{Refense Waste Processing Facilitity (DKRF)}

The Defense Waste processing Eacility is the facility where waste from the Savannah River Site's Tank Farms is immobilized in borosilicate glass, in preparation for shipment to the repository.

\section{Design-basis glass}

The design-basis glass for the DWPE refers to the glass composition assumed for design of the DWPE facility. This composition was used to develop physical, radiochemical and chemical data for design of the DWPE. It is based on an early (ca. 1980) set of assumptions about nuclear fuels production and waste generation at. the Savannah River Site. The design-basis glass composition and its set of properties are exemplars of the types of data which will be used to satisfy specifications requiring projections of DWPE glass compositions and properties. The waste composition assumed for the design-basis glass (design-basis waste) represents 
EART TITLE: INTRODUCTION

ITEM TITLE: GLOSSARY

an expected maximum of radiation-related properties, such as dose rate and heat generation. The current design-basis glass composition is that designated "Blend" in Table 3.100.1.

\section{DHPR Stantup Tesk Rrogram}

The DWPE will carry out a comprehensive program to test all systems in the DWPE whici are important to health, safety, environmental protection, and product quality. This program is called the DWPE startup Test Program. It includes all of the nonradioactive testing in the facility, as well as testing which occurs after the start of radioactive operations. A summary of the DWPF Startup Test Program is included in Table 1.200.1. Those parts of the program most relevant to aaceptance of the DWPE product are summarized in Appendix 1.200.3.

\section{End of canister coeling after filding}

Decontamination of the canistered waste form in the Canister Decontamination cell is not allowed until the canister temperature is below $100^{\circ} \mathrm{C}$. This limit is to prevent generation of steam during decontamination using an aqueous frit slurry. Thus, the initiation of decontamination in the Canister Decontamination Cell provides a convenient definition of the end of cooling after filling.

\section{Erit}

Glass-forming chemicals will be added to SRS waste in the DWPE in the form of a pre-melted granular glass product. This material, called frit, makes up about. $64 \%$ of the DWPE glass composition.

\section{Glass Wagte storage Buiddino (GissB)}

After canisters are filled, decontaminated, and welded closed, they will be stored in the GWSB until shipment to a repository.

\section{Inner Canister Closure (ICC).}

After the canister is filled with glass, it revolves away fon a turntable) from the melter pour spout, and is temporarily sealed. 


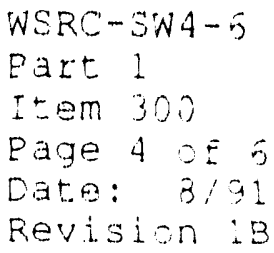

PART TITIE: INTRODUCTION

ITEM TITLE: GLOSSARY

This temporary seal, which is shrink-fit into the top of the canister, is calied the inner canister closure. Its purpose is to prevent water (or other foreign materials) from entering the canister between the filling operation and the time when the canister is welded closed, particularly during decontamination.

\section{Rrecioitate Hydrolysis Aoueous (PHA)}

The soluble portion of SRS waste will be treated in the Tank Farm with sodium tetrapherylborate and sodium titanate to remove radioactive cesium and the trace amounts of strontium and plutonium it convains. In the DWPE, most of the organic content of the tetraphenylborate salt will be removed from the precipitate by hydrclysis with formic acid. The aqueous fraction of the hydrolysis process, or PHA material, will be mixed with the sludge and frit to produce melter feed.

\section{Brecigion}

As used in the WCP, precision refers to the ability of a measurement system to reproduce a measurement repeatedly. The standard deviation (or relative standard deviation) is a measure of the precision of a measurement system.

\section{Rroduction Records (PR)}

The Production Records are documents that describe the contents and important characteristics of DWPE canistered waste forms. They are specific to individual canistered waste forms. They are not the detailed records of the production of each canistered waste form, but summarize those records, and provide the means to retrieve them, if necessary.

\section{Projected alassas}

The Waste Acceptance Preliminary Specifications require that the DWPF project the range of glass compositions, and other properties, to be produced in the DWPE. The projected glasses represent both extreme points in that range of compositions (based on possible variations in waste composition, processing equipment performance, and process instrumentation and analysis), and more central 
NSRC- $3 N_{4}^{4}-5$

Part i

Item 300

Page 5 of

Dée: $3: 91$

Revision :a

PART TITLE: " INTRODUCTION

ITEM TITLE: GLOSSARY

points (compositions expected to be actualiy produced). The pr:jected glasses will be used for qualification testing of the DNPE product.

\section{Oualification Runs (OB)}

Before the DWPE begins radioactive operations, the integrated operation of the processing equipment will be extensively tested as part of the DWPE Startup Test Program. The Qualification Runs will be directed toward demonstrating the ability of the DNPE process and facility to comply with the waste Acceptance Preliminary specifications. The Qualification Runs are summarized in Appendix $1.20 ? .3$.

\section{Sludge}

The insoluble portion of SRS waste is referred to as sludge. The sludge consists primarily of hydroxides and hydrous oxides of iron, aluminum, and manganese, and contains essentially a: - of the long-lived radionuclides in the waste.

\section{Supedier Surveid lance Representativa}

As part of procurement of important items, such as the canister, inspections will be made at the manufacturer's location, to verify that specifications are being met during fabrication. Supplier Surveillance Representatives are the individuals who perform this service for the DWPE.

\section{Tank Fanm}

Currently, SRS high-level radioactive waste is stored in large (up to 5,000,000 L) carbon-steel tanks on site. The areas containing these tanks are known as the Tank Earms.

\section{Haste Acceptance Process activities}

Waste Acceptance Process activities are those activities which will be performed by or for the DWPE to establish the acceptability of DWPE canistered waste forms. The Waste Acceptance Process activities are identified and described in the waste Form Compliance Plan. 


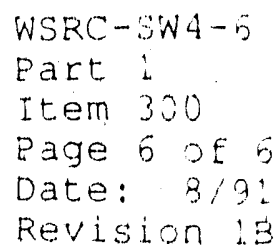

Eigure 1.300.1 DWPE Production Batches

$1 / 6$ of batch feeds DWPF for $\sim 4$ months

Feeds DWPF for -2.5 years

PRECIPITATE BATCH
IN TANK FARM,
$1,000,000$ GALLONS

MACROBATCH

Equals precipitate + sludge until one of those leeds changes; yields $\sim 30$ process batches and $\sim 120$ canisters.

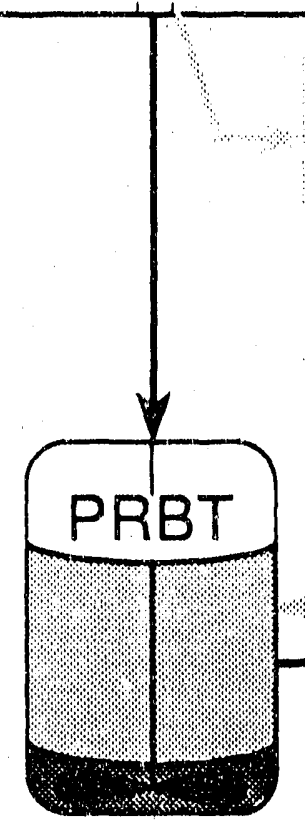

\section{PROCESS BATCH}

A portion of the macrobatch that passes through each process vessel: its composition will change because of heels in the tanks.

\begin{tabular}{l}
\hline SLUDGE BATCH \\
IN TANK FARM, \\
700,000 GALLONS
\end{tabular}

Ol heels in the lanks.

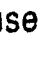

\&

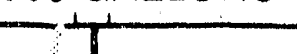




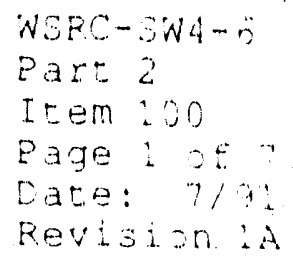

PART TITLE: DWEE PROCESS DESCRIPTION

ITEM TITLE: OVERVIEW OE DWEE PROCESS

Intreduction

At tha Savannah River Site (SRS) in Aiken, South Carolina, the residue of over thirty years of reprocess.ng of irradiated nuclear fuels for national defense purposes is currently stored in carbon steel tanks. In the Defense waste processing Facility (DWPE), the SRS high-level radloactive waste (HLW) will be converted from an alkaline slurry to a durable borosilicate glass. Descriptions of the DWPE and its mission have appeared in the open technical 1iterature (see references at the end of this section). An overview of the DWPE process is presented here, with emphasis on the production of canistered waste forms. A diagram of the waste immobilization process is shown in Eigure 2.100.1.

Waste erocessing

Waste Precessing in Tank Earms.

The SRS waste is currently stored on site in carbon steel tanks and exists in three forms: sludge, salt solution, and saltcake (formed through concentration of salt solution). The sludge, comprising approximately 10 volo of the stored waste, consists primarily of precipitates of the hydroxides of iron, aluminum, and manganese. The salt (saltcake and salt solution) is largely sodium nitrate, sodium nitrite, sodium aluminate, and sodium hydroxide. The sludge contains most of the radioactivity in the waste, including smali amounts of actinides not recovered in the reprocessing plants, and most of the fission products, except for cesium-137. The salt fraction contains most (ca. 958) of the cesium-137.

The salt (saltcake and salt solution) is decontaminated for disposal as low-level waste by removing the radionuclides by precipitation and sorption. Dissolved saltcake and salt solutions are pumped to an existing waste tank in the Tank Farm for pretreatment. Here a solution of sodium tetraphenylborate is added. Insoluble salts of $\mathrm{K}, \mathrm{Cs}$, and $\mathrm{NH}_{4}$ (if present) form a tetraphenylborate precipitate. At the same time, a small amount of sodium titanate slurry is added to adsorb residual $\mathrm{Sr}$ and $\mathrm{Pu}$ in the salt solution. 
WSRC $-S W 4-6$

Part 2

Item 100

Page 2 of 7

Date: $7 / 91$

Revision $1 \mathrm{~A}$

\section{PART TITLE: DWPE PROCESS DESCRIRTION \\ ITEM TITLE: OVERVIEW OE DWEE PROCESS}

The precipitate slurry is concentrated by continuous filtration, washed to a low soluble salt level, and pumped to the DWPE, After further processing, the concentrated radionuclides from the salt solution are immobilized in borosilicate glass (see below). The decontaminated salt solution is blended with portland cement, slag, and flyash in a separate faclilty for disp:sal as low-level waste (saltstone process).

Sludge waste is also pretreated in existing waste storage tanks. The object is to dissolve soluble, nonradioactive, ingredients, such as aluminum, so that they may be processed with the salt solution into low-level waste rather than into the more costly highlevel waste glass. High-aluminum sludges are leached with excess caustic to dissolve about $75 \%$ of the hydrated alumina and reduce the volume of this type of sludge by about 50\%. All types of sludge are washed with water to reduce the soluble salt content of the sludge slurry. Current plans are to accumulate about $2500 \mathrm{~m}^{3}$ of washed sludge slurry, and then to use the batch of sludge siurry as feed to the DWPF. Each batch of sludge will supply the DWPE for two to three years of operation.

\section{Preciotiate Processing}

Within the vitrification building, tetraphenylborate salts are further processed to remove most of the organic material. About 90 of the phenyl groups of the tetraphenylborate salts are removed by a formic acid hydrolysis process. The aqueous product contains the cesium and other cations from the tetraphenylborate salts as soluble formate salts. The aqueous product also contains boric acid, excess formic acid, and about loo of the original phenyl groups in water-soluble forms (such as phenol and phenylboric acta). The aqueous product and the insoluble titanate with adsorbed radionuclides are collected and fed to the sludge Receipt and Adjustment Tank (SRAT) prior to vitrification.

\section{Sludge Processing and Adjustment}

The washed sludge slurry and the precipitate hydrolysis product are mixed together in the SRAT. Formic actd is also added to the SRAT which reduces mercury (a minor component of the sludge) to the elemental state. The formic acid also reduces the yield 
WSRC-SW4-6

Part 2

Item 100

Page 3 of 7

Date: $7 / 31$

Revision $1 \mathrm{~A}$

PART TITLE: DWPE RROCESS DESCRIPTION

ITEM TITLE: OVERVIEW OF DWPE PROCESS

stress of the slurry, and provides a reductant to the melt which minlmizes foaming. The mercury is steam distilled from the siluriy and eventually recovered in reusable, metallic form.

Waste Eorm Eroduction

Melter Feed preparation

The slurry is then transferred to the Slurry Mix Evaporator (SME) where premelted and sized borosilicate glass frit is added. Approximately $2 / 3$ of the necessary frit is pumped directly to the SME. The remaining $1 / 3$ of the frtt is first used for canister decontamination (frit blasting), and then is added to the SME. The Erit-waste-formate slurry is then concentrated to about 45 wto total solids by bolling. This mixture is transferred to the Melter Feed Tank (MFT), which delivers feed to the melter.

\section{Melter operation}

Vitrification of SRS waste is accomplished in a slurry-fed, Jouleheated melter (Elgure 2.100.2). The feed slurry is introduced from the top of the melter. It forms a crust, or cold cap, on the surface of the melt pool as the water evaporates from the feed slurry, and is removed via the off-gas system. Two pairs of diametrically opposed electrodes supply electric power directly to the melt. The nominal glass temperature berieath the cold cap is $1150^{\circ} \mathrm{C}$, but varies throughout the melter. The cold cap melts from the bottom and forms the borosilicate waste glass matrix. For a nominal pour rate of $100 \mathrm{~kg} / \mathrm{hr}$, and a nominal glass melt weight of $6500 \mathrm{~kg}$ in the melter, the residence time in the meiter is about 65 hours. The dome of the melter contains four pairs of metal resistance ild heaters that are used to provide the heat for startup, as well as supplemental heat during glass production.

\section{Canister Eduling}

Glass is normaliy removed from near the bottom of the DWPE melter through a riser and pour spout (Elgure 2.100.2). The canister, on the pour turntable, is connected to the melter by a beliows assembly, which seals the carister-pour spout connection. Pouring is accomplished by drawing a vacuum on the pour spout relative to the melter. Canister filling is monitored by both gamma and neutron 


\section{PART TITLE: DWPE PROCESS DESCRIPTION}

ITEM TITLE: OVERVIEW OE DWPE PROCESS

level detection systems, and by a weight system. When the desired level of fill in the canister is achieved, pouring is stopped by equalization of the pressure between the melter and the pour spout. After pouring is stopped, venting of the canister to the off-gas system is continued for about 30 minutes, to collect volatile radionuclides (such as Cs-137) which may be emitted from the surface of the glass. The canister is then rotated from beneath the pour spout. The canister is then temporarily sealed (ICC) with a tapered pluy that shrink-seals as cooling continues, crea"ing a leaktlght seal of better than $2 \times 10^{-4}$ atm-cc He/sec.

\section{Canister Decontamination}

Erit slurry blasting is used to remove contamination and metal oxides from the canister surface. Cleaning is performed by rotaing the canister in an enclosed chamber and using air injected wet glass frit blasting on all exposed surfaces. The used frit slurry is then sent to the SME for melter feed preparation.

\section{Elnal canister clesure}

The canister is sealed by upset resistance welding a $12.7 \mathrm{~cm}$ diameter. plug into the canister nozzle. After decontamination and drying, the temporary seal is pushed down in the canister neck, exposing clean metal for a permanent plug weld. The plug, which is slightly larger in diameter than the nozzle bore and has a tapered edge, is centered in the nozzle. The canister is supported by its flange on the welder bottom electrode, then the upper electrode is lowered onto the plug. As a force of 330,000 newtons is applied to the plug, a current of 240,000 amperes is passed through the plug and nozzle. The $40 \mathrm{~cm}$ line of contact is heated (but not melted), the plug is forced into the nozzle, and a $1-\mathrm{cm}$ thick, solid state weld is made in 1.5 seconds. The weld produced is sufficiently leaktight to meet specification 2.2 (based on experimental evidence the weld is leaktight to approximately $1 \times 10^{-9}$ atm-cC He/sec, and of compaxable strength to the base metal). Technlques have also been developed and demonstrated to seal canisters whose weld parameters are outside operating limits. 
WSRC-SW4-б

Part 2

Item 100

Page 5 of $?$

Date: $7: 31$

Revision $1 \mathrm{~A}$

EART TITLE: DWEE PROCESS DESCRIETION

ITEM TITLE: OVERVIEW OF DWPE PROCESS

Interim storage

The filled, decontaminated, and sealed canisters are moved by a shielded transport vehicle and stored in the Glass waste storage Building (GWSB). Air is forced across the canisters' surfaces to prevent overheating of the building, and to keep the canisters cool. Although there should be no contamination in the GWSB, the air forced across the canisters' surfaces is passed through HEPA filters so that no contamination is released.

Beferences

1. R. Maher, L. F. Shafranek, J. A. Kelley, and R. W. Zeyfang, "Solidification of the Savannah River Plant High-Level Waste", American Nuclear Society Trans., 39, p. 228, 1981.

2. M. D. Boersma, "process Technology for the Vitrification of Defense High-Level Waste at the Savannah River Plant", American Nuclear Society - Fuel Reprocessing and Waste Management proceedings, 1, p. $131-47,1984$.

3. R. G. Baxter, "Design and Construction of the Defense waste Processing Facility Project at the Savannah River Plant", Waste Management ' 86, 2, High-Level Waste, p. 449, 1986.

4. R. G. Baxter, Defense Waste Processing Facility Wasteform and Canister Description, USDOE Report DP-1606, Revision 2, E. I. DuPont de Nemours and Co., Inc., Savannah River Plant, Aiken, SC 19808 (1988).

5. A. E. Weisman, L. M. Papouchado, J. R. Knight, D. L. McIntosh, "High Level Waste Vitrification at the Savannah River Plant,"

Waste Management 88, 2, RoY G. Post (ed.), 203-10 (1988). 


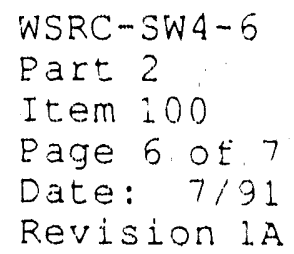

EIGURE 2.100.1 Immobilization of Savannah River Site waste

\section{TANK FARM}

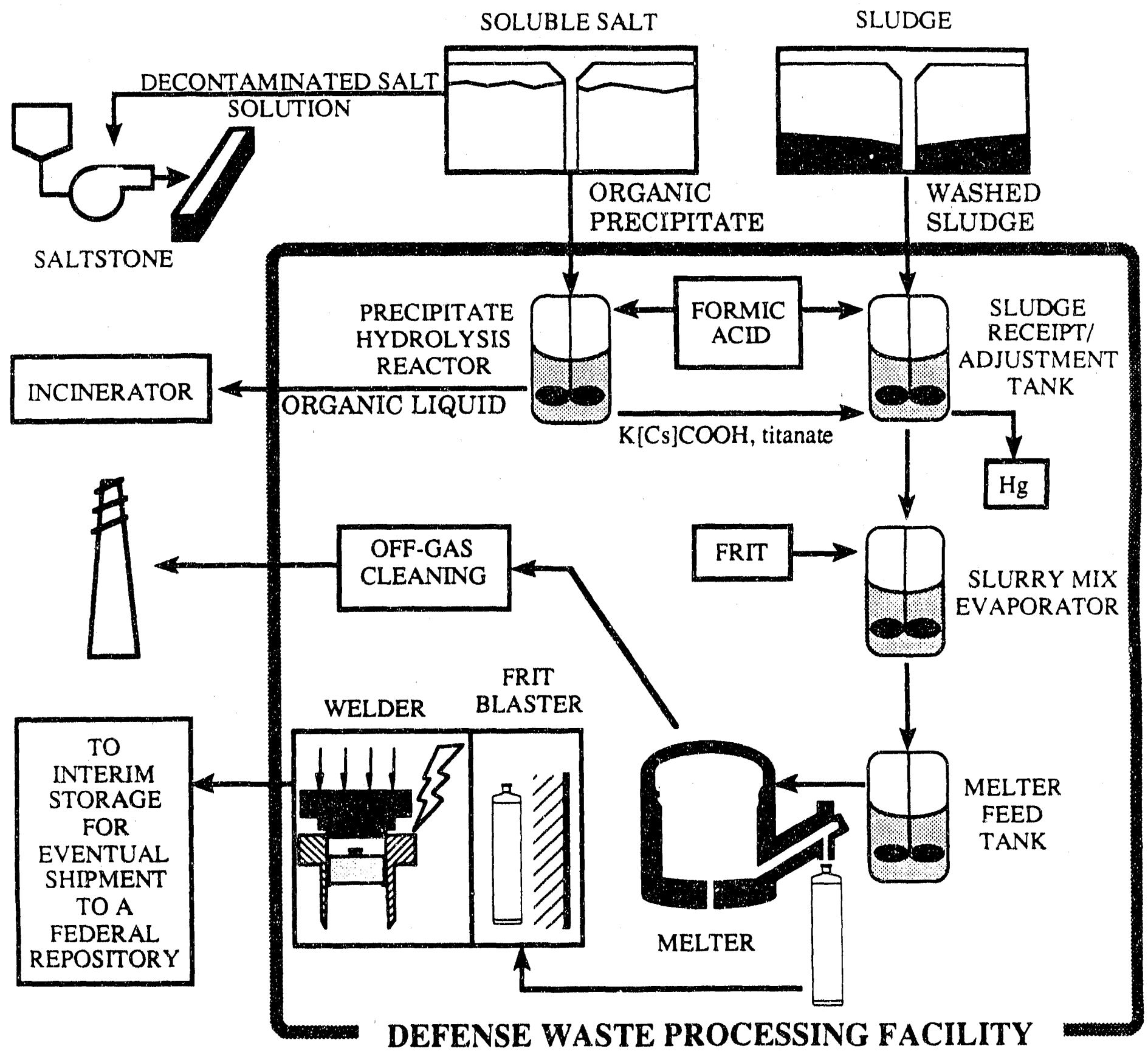


WSRC - SW 4-

Part 2

Item 100

Eage 7 of ?

Date:

Revision iA

EIGURE 2.100.2 DWPE Melter system

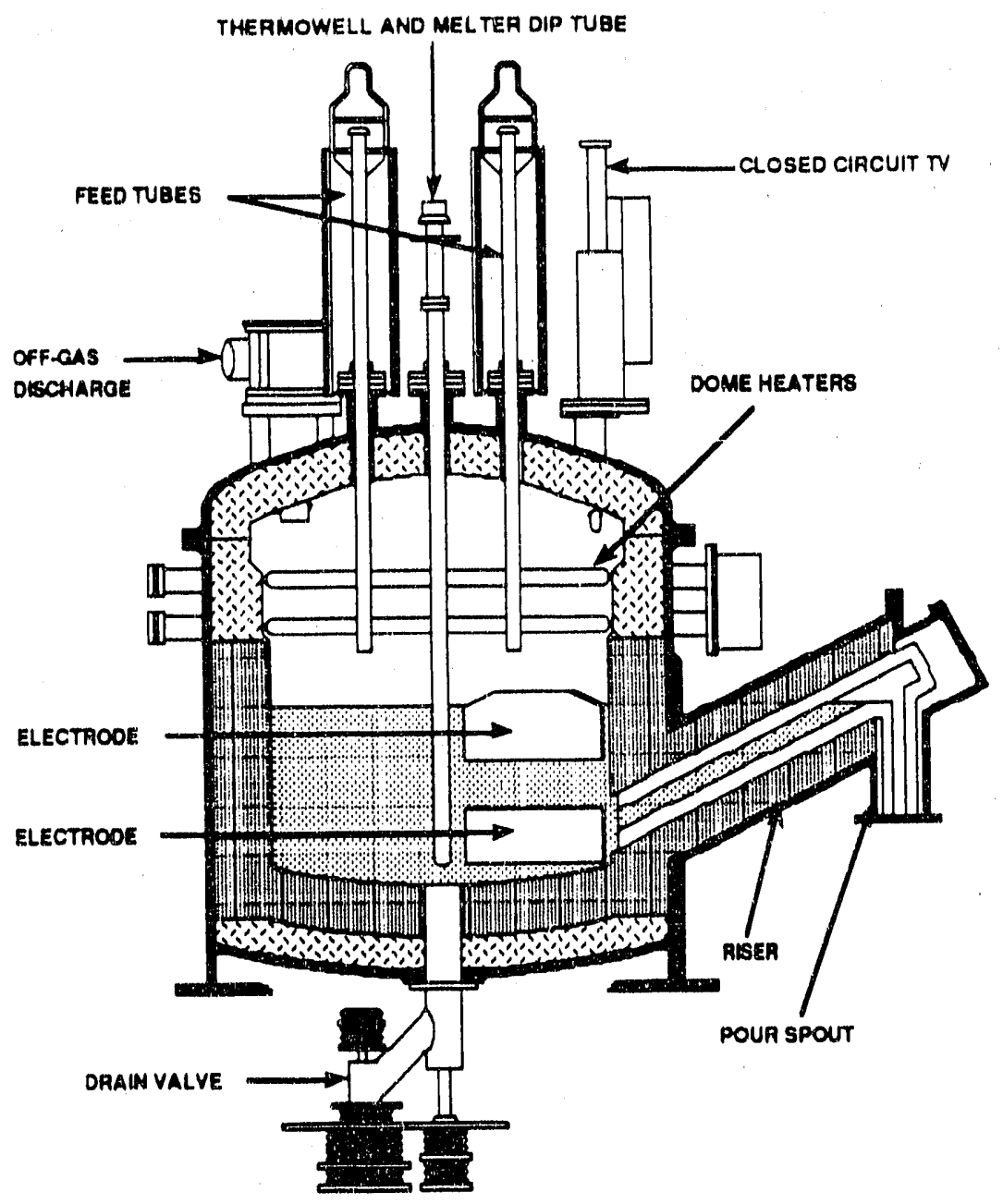

MELTER CHARACTERISTICS

Weight of assembly filled with glass

$73,000 \mathrm{~kg}$

Total melter volume

$5.5 \mathrm{~m}^{3}$

Average glass volume

$2.5 \mathrm{~m}^{3}$

Glass height along sidewall

$0.86 \mathrm{~m}$

Glass height along centerline

$0.95 \mathrm{~m}$

Melter diameter

$1.8 \mathrm{~m}$

Pour spout inside diameter

$5 \mathrm{~cm}$

Riser angle 


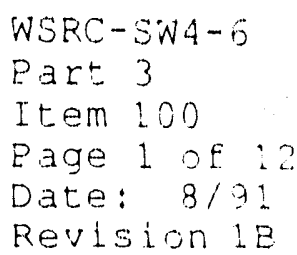

PART TITLE: WASTE EORM SPECIEICATIONS

ITEM TITLE: 1.1 .1 CHEMICAL COMPOSITION PROJECTIONS

1.1 CHEMICAL SPECIFICATION

The waste form is borosilicate waste glass.

\subsubsection{Chemical Composition Projections}

The producer shall include in the Waste Form Qualification Report (WQR), the chemical composition and crystalline phnse projections for each waste type. The method to be usad to demonstrate compliance shall be described by the producer in the Wast.e Form Compliance Plan (WCP). Waste form compositions not available for reporting in the initial WQR shall be included in an addendum to the WQR .

\section{Rationale}

The regulatory requirements out lined in $10 \mathrm{CFR} 60.135$ (c) state that: (1) "All such radioactive wastes shall bo in solid form and placed in sealed containers"; (2) Particulate waste foros "shall be consolidated (for example, by incorporation into an encapsulating matrix) to limit the availability and generation of particulate"; and (3) "All combustible radioactive waste shall be reduced to a noncombustible form ..." Borosilicate glass was selected because it meets these requirements and because of its durability, stability, and ease of manufacture.

The chemical specification addresses two repository information needs. Information on the planned production is required to allow testing of material that is representative of what is to be produced. Secondly, information on the canistered waste forms is required to confirm that the material actually produced is within the range of materials tested.

The measurement of canistered waste form compositions for each waste type is necessary to allow adequate evaluation of uncertainties in waste form composition for repository performance assessment. Analysis of elements present above the 0.5 of threshold will include those neaded to evaluate process conditions and uniformity. These elements represent at least 98 wt $f$ of the glass.

Oxygen is excluded from the requirements for analysis because it would not provide any data relevant to determination of tha va- 
WSRC $-3 W 4-6$

Part 3

Item 100

Page 2 of 12

Date: $8 / 91$

Revision iB

PART TITLE: WASTE EORM SPECIEICATIONS

ITEM TITLE: 1.1 .1 CHEMICAL COMPOSITION PROJECTIONS

lence state of radionuclides in the glass. A direct measurement of oxygen would have an uncertainty of \pm 1 percent of the measured value. The radionuclides for which release rate control is reguired are present in concentrations that are collectively less than 0.5 percent; of these, only a small number, such as technetium and plutonium, are redox sensitive. Since other, nonradioactive oxides are present in much greater concentrations, a measurement of the oxygen concentration witb an uncertainty of more than 1 percent would provide no information on the valence state of the radionuclides of interest.

However, knowledge of the oxides present in the glass, which define the redox state of the glass, is needed for repository performance assessment.

\section{cempliance strategy}

A set of projected glass compositions will be defined, which will span the range of properties of glasses expected to be produced in the DWPE. The projected compcsitions will be defined based on the compositions of wastes currently stored in the Tank Farms at SRS, anticipated blending schemes for the wastes in the Tank Farm, hypothetical waste compositions, and the expected composition(s) of the glass frit to be used. Among these compositions, a credible "worst case" will also be included. Each sludge batch from the Tank Earm will constitute a waste type for compliance with this specification.

The range of glass compositions will be of a broad nature because of the uncertainties in the assumptions. These estimates will take into account all of the information available at the time they are made, but will not necessarily reflect the composition of any particular waste forms subsequently produced. However, it is anticipated that the range of properties (processing properties, durability as measured by the product Consistency Test, crystallization behavior, and waste solubility) of compositions projected. as above will encompass those of all glasses produced in the DWEE. If future site processes significantly change so that the composition of the waste would produce a glass whose properties might fall outside the range spanned by the projected compositions, then the composition (and properties) of glass to be made from the new waste will be projected in the same manner as for current waste 


WSRC-SW4-6
Part 3
Item 100
Page 3 of :2
Date: $8 / 91$
Revision 1B

PART TITLE: WASTE EORM SPECIFICATIONS

ITEM TITLE: 1.1 .1 CHEMICAL COMPOSITION PROJECTIONS

compositions. The qualification of new compositions is discussed further in Part 3, Items 500 and 600 .

Glasses representing each of the projected compositions will be exposed to the range of thermal conditions expected during filling and cooling of the DWPE canister. Eor each projected composition, the crystalline phases formed will be identified, and their content determined.

\section{Imolementation}

The plan being followed to satisfy this specification is outlined in Figure 3.100.1. The plan includes the following elements:

- Identification of the compositions of the waste currently stored in the waste tanks, as distinct waste types.1-5

- Definition of the anticipated blending schemes for waste currently stored.

- Identification of hypothetical waste compositions.

- Specification of the glass frit composition.

- Development of an integrated flowsheet model, which will convert the waste and frit compositions into projected glass compositions.

- Determination of the temperature profile expected for DWPF Canisters during filling with glass, and subsequent cooling.

- Application of that thermal profile to the projected glass compositions, identification of the resultant crystalline phases, and determination of the amounts of each.

\section{Gurrent Waste Inventery}

Projections of the chemical composition of the existing waste inventory are principally based on chemical analyses of individual samples of the waste stored on site. Nuclear materials production processes, and the histories and methods of waste handling at SRS 
WSRC $-S W A-6$

Part 3

Item 100

Page 4 of 12

Date: $8 / 91$

Revision $1 B$

\section{PART TITLE: WASTE EORM SPECIEICATIONS}

ITEM TITLE: 1.1 .1 CHEMICAL COMPOSITION PROJECTIONS

combine to show that the Tank Earm contains several general types of waste:

- H:l ("Heavy Metal" process) high heat waste sludge.

- HM low heat waste sludge.

- Purex high heat waste sludge.

- Purex low heat waste sludge.

- Zeolite resin.

- Coal and sand.

- Silver salts.

- Supernatant salt solutions (primarily sodium salts), and salt cakes. The salt solutions, and the salt cakes after redissolving, will be decontaminated in the waste tanks with sodium tetraphenylborate and sodium titanate.

In general, the waste sludges in the Tank Farm are primarily blends of HM and Purex wastes. The zeolite, coal and sand, and silver salts in the waste are contained in the sludge in only a few of the tanks; thus, these are included in the specific sludge batches in which they are currently scheduled to be processed. All of the sludge components, except halides, will be included in the projections as oxides $\left(e, g ., \mathrm{Ee}_{2} \mathrm{O}_{3}\right)$, or as oxygen-containing salts (e.g., phosphates, sulfates). The material fed to the melter from decontamination of the supernatant salt solution will also be included in the projections as oxides or oxygen-bearing salts. For both waste streams, halides will be included as halide salts.

\section{Waste Blending}

Feed to the DWPE will be prepared in the SRS Tank Earms, by SRS Waste Management operations. The feed preparation steps include sludge washing and aluminum removal, and salt decontamination with sodium tetraphenylborate and sodium titanate. Waste Management 
WSRC-3W4-5

Part 3

Item 100

Page 5 of 12

Date: $8 / 91$

Revision $1 B$

EART TITLE: WASTE FORM SPECIEICATIONS

ITEM TITLE: 1.1 .1 CHEMICAL COMPOSITION PROJECTIONS

Operations has developed a waste blending strategy which is intended to:

- Minimize dose rate in the DWPE, and in the process for disposal of decon" minated salt.

- Empty the oldest tanks as soon as possible.

- Balance waste types in the DWPE feed, to dampen changes in composition.

The waste blending strategy is further constrained by the connections among the waste tanks.

Each sludge batch is assumed to be a "waste type" for purposes of compliance with this specification. Each sludge batch will provide feed to the DWPE for two to three years. The associated salt compositions which will be processed at the same time are used to define the projected glass compositions. In this way, the blending strategy has been used to develop the projected glass compositions.

dypothetical waste Compesitions

Accurate projection of the chemical composition of future waste is difficilt because of possible SRS nuclear materials production processing changes which could affect waste generation. The compositions of wastes to be generated in the future have been estimated based on historical usage of process chemicals, but modified to reflect current practices in the waste generating processes. The extremes of HM sludges and purex sludges have been used as hypothetical compositions which may represent future waste generation. Three waste compositions have been generated to serve as input for initial composition projections. They are:

- A blend of HM wastes. This waste reflects current reprocessing practices, and may reflect the composition of waste from reprocessing materials from a possible New Production Reactor.

- A blend of purex wastes. Th1s waste reflects current reprocessing practices. 
WSRC-SW $4-6$

Part 3

Item 100

Page 5 of 12

Date: $8 / 31$

Revision $1 B$

PART TITLE: WASTE EORM SPECIEICATIONS

ITEM TITLE: 1.1 .1 CHEMICAL COMPOSITION RROJECTIONS

- The DWPE Design-Basis waste (see Part 1, Item 300), designated "Blend."

Each of these is assumed to be a "waste type" for purposes of compliance with the specification.

\section{Erit}

On a weight basis, DWPF glass will consist of approximately 64 wto borosilicate glass frit, 8 wto oxides from the precipitate hydrolysis product, and 28 wt oxides from sludge (see part 2, Item 100). The glass frit and the precipitate hydrolysis product (PHA) together make up what is called the glass-former composition. The glass-former composition for the DWPE has been developed so that DWPE waste glass will have similar properties to simulated waste glasses previously developed for sludge-only processing. ${ }^{6}$ This has been achieved by modifying the glass frit composition to take into account changes in waste processing, such as the tetraphenylborate precipitation process. Properties which are controlled through modification of frit composition are chemical durability of the glass, solubility of waste in the glass-former, thermal stability of the glass, and reliability of processing behavior and product properties. 7,8

\section{Elowsheet Model}

An integrated flowsheet computer model was used to develop the material balance for design of the DWPE at SRS. ${ }^{9} 10$ This computer model has been modified to incorporate recent modifications of both the DWPE process, and of SRS processes which produce highlevel waste. This model has been used to estimate the nominal average compositions of waste glass that will be produced in the DWPF, based on projections of both current and future waste. The model takes into account

- Sludge and salt precipitate compositions which are fed to the DWPE.

- The Tank Earm waste blending strategy.

- Reactions in the DWPF which alter the chemistry of the feed 
WSRC-SWA-B

Part 3

I.tem 100

Page 7 of 12

Date: B:9:

Revision 1.8

EART TITLE: WASTE FORM SPECIEICATIONS

ITEM TITLE: 1.1 .1 CHEMICAL COMPOSITION PROJECTIONS

streams.

- Available lead time for adjustments to the feed.

- Erit composition.

The reaction chemistry used in the model is based on data obtained in tests using non-radioactive waste simulants. Data from both laboratory and engineering-scale equipment have been incorporated in the model. When possible, these test's have been augmented by laboratory experiments using radloactive waste from the existing inventory.

The model has been used to generate the projected chemical compositions of four waste glasses to be produced from existing highlevel waste inventory. These glasses represent the expected compositions to be produced in the DWPE through at least the first. ten years of operation. The compositions of these four glasses (Batches 1-4) are shown in Table 3.100.1. Also represented in this table are three hypothetical glass compositions produced Erom:

- A glass based on the Design-Basis waste (see Part 1, Item 300), designated "Blend."

- A glass based on HM wastes that represents the upper design limit of glass viscosity that will be produced at DWPE.

- A glass based on Purex wastes that represents the lower design limit of glass viscosity that wlll be processed at DWPE. This glass composition is based on the following assumptions: maximum precipitate feed rate to the DWPF, minimum sludge feed rate, minimal removal of soluble salts during sludge processing in the Tank Farm, and use of a frit higher in alkali than the frit which will be used initially in the DWPE. Thus, it represents a possible, though unlikely, worst-case composition.

\section{Crustaldine Rbases}

Prototypic DWPF canisters have been instrumented with thermocouples and filled under both expected conditions and likely process upset conditions. The thermal profile during flliing and cooling 
WSRC - SWA - 5

Part 3

Item 100

Page 8 of 12

Date: $8 / 91$

Revision 18

\section{PART TITLE: WASTE EORM SPECIEICATIONS}

ITEM TITLE: 1.1 .1 CHEMICAL COMPOSITION PROJECTIONS

was recorded. Several cantsters were fllled to determine the variability in the thermal profile.

Samples of simulated waste glass of each of the profected compositions will be subjected to the thermal conditions determined from the prototypic canisters, both at the surface of the canister (approximating quenched conditions) and along the centerline (probable worst-case conditions). Crystalline phases generated from these heat treatments will be identifled, and the amount of each quantified, using the methods described in Part 3, Item 600.

\section{Quadification ef Euture Waste Glass compesitions}

It is quite possible that, at some time in the future, the composition of waste fed to the DWPE will change significantly. In that case, the DWPE proposes to apply Part 6, Item 200, in the followling manner.

- A determination wlil be made of whether the new waste composition wlll produce a glass with different properties (crystallization behavior, or product Consistency Test results) than represented by the set of projected compositions. The repository program will be notified in writing of the results of the determination. If the properties of the new glass are bounded by the properties of the set of projected compositions, the DWPF will propose that the WQR be updated to include the new composition, and that no further action is needed. If the waste will produce a glass with properties outside the range of those already profected, then the DWPE will propose activities to be performed (similar to those described in this item; in part 3, Item 500; and in part 3. Item 600) to ensure that the waste produces a glass which complies with specifications.

- Once agreement is reached with the repository program on the appropriate actions, they will be carried out, and the WQR revised to reflect their results.

\section{Decumentation}

The Waste Form Qualification Report will detall the development of the projected glass compositions, and the compositions themselves. The expected temperature proflles of canisters during filling and 
WSRC $-S W 4-5$

Part 3

Item 100

Page 9 of 12

Date: $8 / 91$

Revision 1.B

PART TITLE: WASTE FORM SPECIEICATIONS

ITEM TITLE: 1.1.1 CHEMICAL COMPOSITION PROJECTIONS

cooling wlll be provided. The results of exposing samples representative of each profected glass to the expected thermal profile will be reported, including the identity and amount of any crystalline phases formed.

References

1. J. A. Stone, J. A. Kelley, and T. S. MCMllian, Sampling and Analysis of Savannah River Plant High-Level Waste Sludges, USERDA Report DP-1399, E. I. DuPont de Nemours and Co., Inc., Savannah River Plant, Alken, SC 29808 (1976).

2. J. A. Stone, Saparation of SRP Waste Sludges and Supernates, USERDA Report DP-1441, Revision 1, E. I, DuPont de Nemours and Co., Inc., Savannah River Elant, Aiken, SC 29808 (1976).

3. R. S. Ondrejcin, Chemical Composition of Supernates Stored in SRP High-Level Waste Tanks, USAEC Report DP-1347, Revision 1, E. I. Dupont de Nemours and Co., Inc., Savannah River Planc, Aiken, SC 29808 (1974).

4. L. W. Gray, M. Y. Donnan, B, Y. Okamoto, Chemical Characterization of SRP Waste rank Sludges and Supernates, USDOE Report DP1483, E. I. DuPont de Nemours and Co., Inc., Savannah River Plant, A.tken, SC 29808 (1979).

5. R. G. Baxter, Description of Defense Waste Processing Facility Reference Waste roxm and Carister, USDOE Report DP-1606, Revision 1, E. I. Dupont de Nemours and Co., Inc., Savannah River Plant, Aiken, SC 29808 (1983).

6. P. D. Soper, D. D. Walker, M. J. Plodinec, G. J. Roberts, and L. F. Ilghtner, "Optimization of Glass Composition for the VitriElcation of Nuclear Waste at the Savannah River Plant," Budl. Am. Cer. Soc., 62, 1013-8 (1983).

7. M. J. Plodinec, "V1trification Chemistry and Nuclear Waste," J. Non-Cryst. Solids, 84, 206-14 (1986).

8. C. M. Jantzen, "systems Approach to Nuclear Waste Glass Deve1opment, " J. Non-Cryst. Solids, 84, 215-25 (1986).

9. J. R. Eowler, et al., "Large-Scale Process Simulation - A Case 


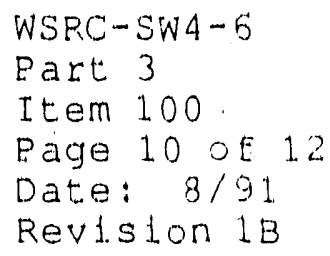

EART TITLE: WASTE EORM SPECIEICATIONS

ITEM TITLE: 1.1.1 CHEMICAL COMPOSITION PROJECTIONS

Study, Integrated Waste processing Elowsheet for the Savannah River Site," USDOE Report WSRC-RP-89-1018, Westinghouse Savannah River Co., Aiken, SC 29802 (1989).

10. Basic Data Report for the Defense Waste Processing Facility, Revision 92, USDOE Report DRSE 80-1033 (1988). 
WSRC-SWA-

Part 3

Item 100

Page 1. OE ?

Date: $8 / 9$.

Revision $1 \mathrm{~B}$

TABLE 3.100.1 Erofected DWPE Waste Glass Compositions.

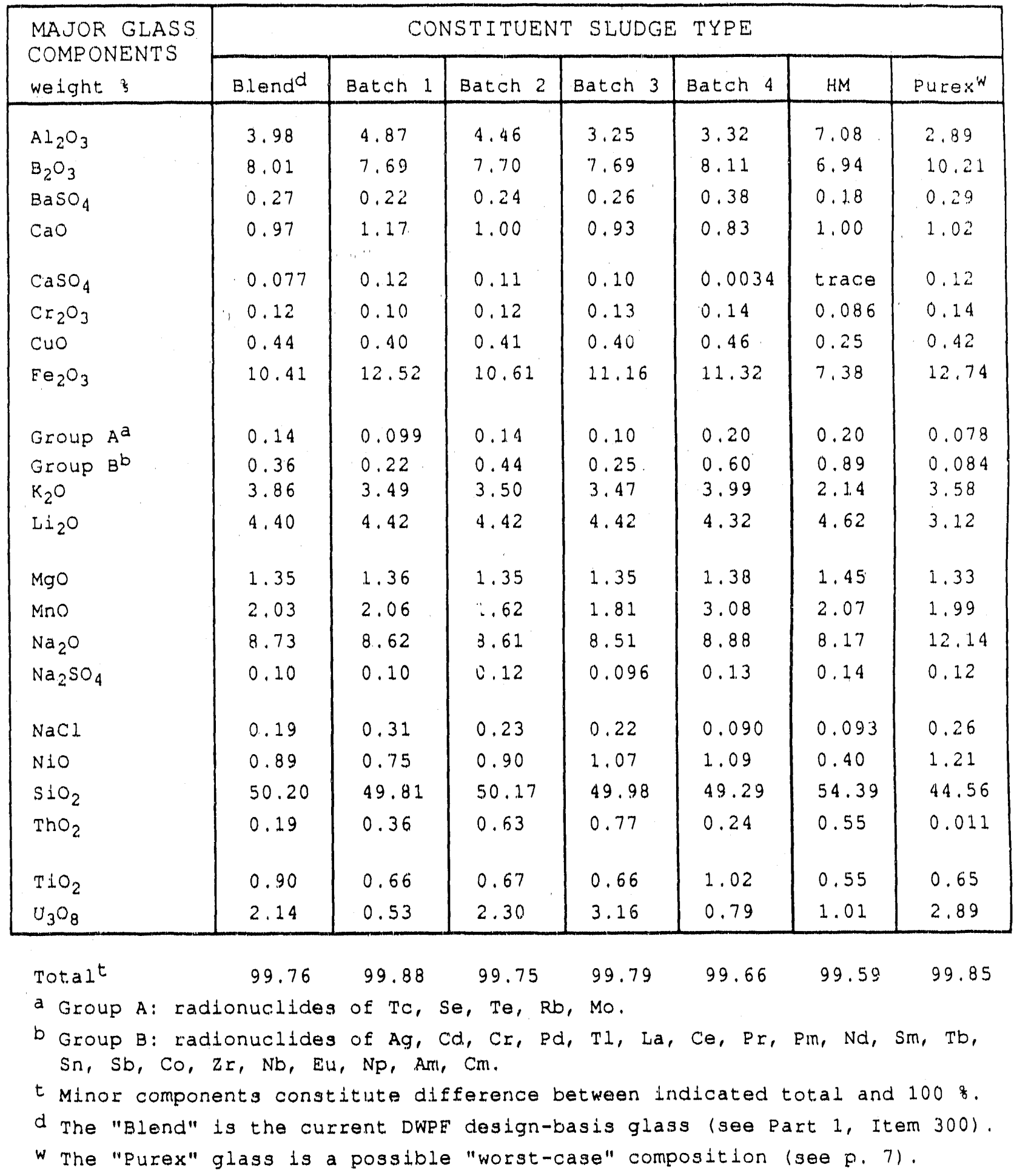




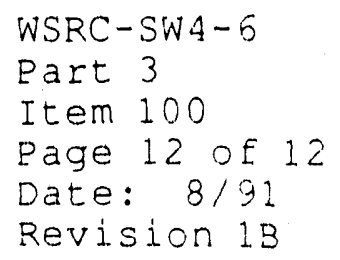

EIGURE 3.100.1 Tasks planned to satisfy specification 1.1.1, Chemical Composition Erojections.

Develop integrated flowsheet model.

[SRL]
Determine the composition of waste stored in Tank Farm [SRL]

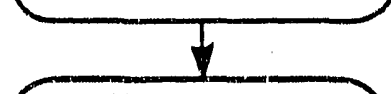

Identify blended waste batches proposed for DWPF processing.

[Waste Management]

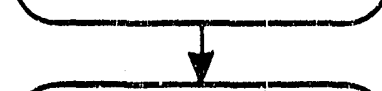

Develop glass frit composition(s). [SRL]

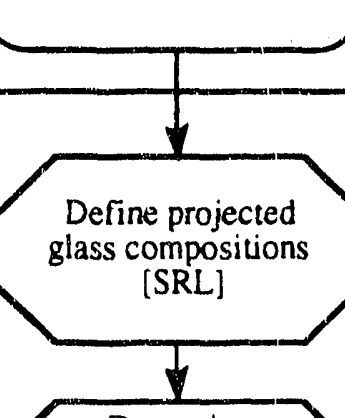

Determine

glass temperatu:es during filling and cooling.

[SRL]

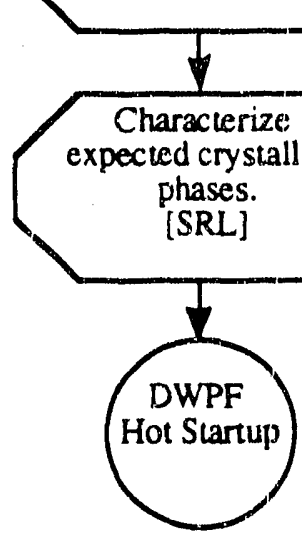

Identify hypothetical waste types to be generated. [SRL] 


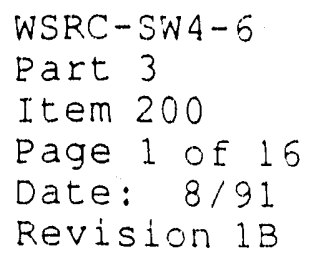

PART TITLE: WASTE FORM SPECIEICATIONS

ITEM TITLE: 1.1 .2 CHEMICAL COMPOSITION DURING PRODUCTION

\section{1 .2 Chemical composition During production}

The producer shall include in the Production Records the oxide composition of the glass waste form for the oxides of elements present in concentrations greater than 0.5 percent by weight for each waste type. The producer shall describe the method to be used for compliance in the WCP. An estimate of the exror of the composition and the basis for the estimate shall be reported in the WQR.

\section{Bationale}

The regulatory requirements outlined in $10 \mathrm{CFR} 60.135$ (c) state that: (1) "All such radioactive wastes shall be in solid form and placed in sealed containers"; (2) Particulate waste forms shall be consolidated (for example, by incorporation into an encapsulating mat $x i x)$ to limit the availability and generation of particulate"; and (3) All combustible radioactive wastes shall be reduced to a noncombustible form...". Borosilicate glass was selected because it meets these requirements and because of its durability, stability, and ease of manufacture.

The chemical specification addresses two repository information needs. Information on the planned production is required to allow testing of material that is representative of what is to be produced. Secondly, information on the canistered waste forms is required to confirm that the material actually produced is within the range of materials tested.

The measurement of canistered waste form compositions for each waste type is necessary to allow adequate evaluation of uncertainties in waste form composition for repository performance assessment. Analysis of elements present above the 0.5 percent threshold will include those needed to evaluate process conditions and uniformity. These elements represent at least 98 weight percent of the glass.

Oxygen is excluded from the requirements for analysis because it would not provide any data relevant to determination of the valence state of radionuclides'in the glass. A direct measurement of oxygen would have an uncertainty of \pm 1 percent of the measured value. The radionuclides for which release rate control is re- 
WSRC $-S W 4-6$

Part 3

Item 200

Eage 2 of $: 6$

Date: $8 ; 91$

Revision 13

PART TITLE: WASTE EORM SPECIEICATIONS

ITEM TITLE: 1.1 .2 CHEMICAL COMPOSITION DURING RRODUCTION

quired are present in concentrations that are collectively less than 0.5 percent; of these, only a small number, such as technetium and plutonium, are redox sensitive. Since other, non-radioactive oxides are present in much greater concentrations, a measurement of the oxygen concentration with an uncertainty of more than 1 percent would provide no information on the valence state of the radionuclides of interest.

However, knowledge of the oxides present in the glass, which define the redox state of the glass, is needed for repository performance assessment.

Sempliance strategy

The DWPE's strategy for determining the chemical composition of DWPE glass during production (shown in Eigure 3.200.1) is based on the relatively constant nature of the sludge feed to the DWPE over the life of each Tank Farm sludge batch (2-3 years), and of the precipitate feed to the DWPF over the life of each Tank Earm precipitate batch (3-4 months). Thus, for purposes of compliance with the specification, a macro-batch (see part 1, Item 300) constitutes a waste type.

Samples from each Tank Earm sludge and precipitate batch (which together constitute the macro-batch) will be analyzed by SRL to identify the elements which must be reported for compliance purposes (those present in the glass at $\geq 0.5$ wt $\%$ ). This will be done by identifying all elements present in the waste at greater than 1 wto (equivalent to about 0.28 wto in the glass for sludge solids, and 0.08 wto for precipitate solids) which would survive vitrification. While the representativeness of individual Tank Farm samples cannot be demonstrated, SRS's experience with analyses of samples from the Tank Farm indicates that the range of analytical results for samples from a single tank is less than $2 x$ for major elements. Thus, by choosing a conservative value based on Tank Earm sample analyses, the DWPE is assured of reporting all major species.

During processing of each macro-batch in the DWPE, the DWPF laboratory will analyze samples from each process batch (see Part 1 , Item 300 ) to determine the actual content of the reportable elements identified from the Tank Farm samples. There will be $\sim 30$ 


\author{
WSRC-SW $4-5$ \\ Part 3 \\ Item 200 \\ Page 3 of 15 \\ Date: $8 / 31$ \\ Revision 13
}

\title{
PART TITLE: WASTE EORM SPECIEICATIONS \\ ITEM TITLE: 1.1 .2 CHEMICAL COMPOSITION DURING PRODUCTION
}

process batches for each macro-batch. The number of samples to be taken for each process batch and the number of analyses for each sample will be based on the statistical criterion in specification 1.3.2, as is described in part 3, Item 500. These results will then be used by the DWPE to calculate the chemical composition of the glass, which will be reported in the production Records. The composition of the entire group of canistered waste forms produced by a macro-batch ( 120 canisters) will be reported as average values for each component for the entire macro-batch. Standard deviations will also be reported for each component for each macrobatch, based on the entire set of analyses performed on process batches.

The errors associated with this strategy will be characterized during the DWPE startup Test Program, when feed and glass samples will be routinely taken and analyzed in the DWPE. The precision and accuracy of the determination of the glass composition will be calculated based on the results of the DWPE Startup Test Program, and will be reported in the waste Eorm Qualification Report. Preliminary estimates based on SRI experience with similar equipment are provided in this Item.

\section{Implementation}

The tasks planned to satisfy this specification are outlined in Eigure 3.200.2. They are:

- Development of equipment and methods to sample the slurry feed material in the DWPE process vessels.1

- Development of methods for analyses of the major components in each process batch. 2-5 This includes demonstration of these methods in the laboratory with non-radioactive simulants, and in remote facilities with actual radioactive waste.

- Conversion of the analytical methods into procedures for use in the DWPE itself.

- Development of a relationship between feed composition and glass composition. 
WSRC-SW4-5

Part 3

Item 200

Page 4 of 15

Date: $8: 31$

Revision LB

PART TITLE: WASTE FORM SPECIEICATIONS

ITEM TITLE: 1.1 .2 CHEMICAL COMPOSITION DURING PRODUCTION

- Estimation of the error in the reported composition. This activity will be performed as part of the startup Test program, and will be based on analyses of the components of the error, and on comparisons of the reported composition (based on analyses of feed material) to the actual composition of the glass.

- Development of analytical methods for samples of production glass.

\section{Sampling of Eeed Materials fromprocess Vesseds}

In the DWPF, feed material will be pumped out of each process vessel, through a recirculating sample loop, and back into the process vessel. This recirculating 100 p carries feed material from the process vessel in the canyon cell to the DWPE laboratory. The recirculating loop limits the amount of radioactive material in the laboratory, while still providing a sample which is representative of the contents of the process vessel. This is shown in Eigure 3.200 .3 for the Melter Feed Tank.

To take a sample, a portion of the feed from the recirculating loop is diverted into a sample vial in the laboratory. This diversion is accomplished through use of a manually actuated ram which is part of the DWPE remote sample valve (shown in Eigure 3.200.4). After a sample is captured, the ram is retracted, closing the valve. The sample vial is then removed, and the contents prepared for analysis.

\section{Analysis of Feed Material}

SRL has developed analytical methods for composition determination in the DWPE laboratory.2-5 According to these methods, samples of melter feed slurry will be converted to glass in the laboratory before analysis. This allows use of stable glass standards for laboratory QC purposes, and will simplify the correlation between feed and glass composition (see below).

After vitrification of the melter feed slurry, the vitrified sample is then dissolved for analyses. The primary techniques to be used are Inductively Coupled Plasma spectroscopy (ICP), and Atomic Absorption spectroscopy (AA). Table 3.200.1 identifies the analytical technique which will be used to determine the concentra- 
WSRC - SW $4-6$

Part 3

Item 200

Page 5 of 1.5

Date: $8 / 91$

Revision $1 B$

\section{PART TITLE: WASTE FORM SPECIEICATIONS}

\section{ITEM TITLE: 1.1 .2 CHEMICAL COMPOSITION DURING PRODUCTION}

tion of each of the reportable elements in the vitrified sample:2-5 The list of reportable elements is based on the glasses identified in Part 3, Item 100 (Table 3.100.1).

The Waste Eorm Qualification Report will contain detailed descriptions of each of the analytical methods, as well as examples of their application in the laboratory on non-radioactive simulants, and in remote facilities on actual radioactive waste slurries and glasses. The latter studies will establish the minimum error which can be expected from application of these methods to DWPE feed materials, in practice.

\section{Eacility-Specific Analytical Precedures and OA/OC Brogram}

The DWPE is currently evaluating (and modifying, as necessary) each of the methods proposed for use in the DWPE laboratory. As each method is adapted to the specific equipment and layout of the DWPE laboratory, detailed procedures for its use and control are also developed.

Because of the importance of glass composition to the radionuclide release properties of the glass, the DWPE laboratory is instituting a rigorous quality assurance and control program for slurry sampling and analyses. This will be described in more detail in the glass product control program description (see Part 3, Item 5001 , but is summarized here. The objectives of the program are to ensure the accuracy of the analytical values reported, and to control the precision so that it is at least within expected values.

Glass standards which closely resemble the DWPE final product will be routinely analyzed. The results fron these standards will be used to identify and correct biases, if any. Whenever possible, calibration standards for analytical methods will be materials which are traceable to the National Institute of Science and Technology (NIST) or to other nationally recognized sources. Standard samples will also be analyzed routinely to monitor short- and long-term variances. SRS statisticians will provide support for examination of these data to determine evolutionary trends. Internal and external interlaboratory checks, as well as participation in Materials Characterization Center (MCC) Round Robins, will be used to monitor the accuracy and precision of essential analy- 
WSRC $-S W 4-6$

Part 3

Item 200

Page 6 of 15

Date: $8 / 91$

Revision iB

PART TITLE: WASTE EORM SPECIEICATIONS

ITEM TITLE: 1.1 .2 CHEMICAL COMPOSITION DURING PRODUCTION

ses, and to improve performance.

Quality audits, both internal and external, will be conducted to assure compliance with quality assurance requirements, and to provide a mechanism for continual improvement. Analytical results will be evaluated routinely with methods or procedures supported by SRS statisticians to provide a statistically sound system capable of identifying analytical variances. The following will facilitate the quality improvement process:

- Storage of process and lab standards data. Files will be maintained in a manner which wlll allow historlcal data to be monitored, retrieved and surveyed for overall credibility and suitability to the customers served.

- Records of analytical variances. Elles will be in place to record variances on essential results obtained on process samples and laboratory standards.

- Generation of QC reports. Data from the files will be accessible to generate numerous reports for quality audits and monitoring for improvement. Routlne reports, issued at least quarterly, will be extracted for laboratory standards.

- Linkage to other SRS computers. The system will have the capability to transmit data files to SRS mainframe computers equipped with statistical analysis programs. These programs will be used to calculate the accuracy and precision of the data being produced, as well as other statistical parameters of interest.

\section{Eeed to Glass correlation}

The DWPE will report the chemical composition of the glass based on analyses of melter feed samples. Because the feed samples are vitrified prior to analysis, analyses of feed samples are actually analyses of equivalent glass samples. During production, the composition of canistered waste forms produced during processing of a macro-batch will be reported as the average of the analyses of all the feed hatches produced from that macro-batch. This introduces an error by neglecting the heels from previous batches left in process vessels. The magnitude of this error will be determined during the Startup Test Program. 
WSRC-SW $4-5$

Part 3

Item 200

Page 7 of 15

Date: $8 / 91$

Revision 13

PART TITLE: WASTE EORM SPECIEICATIONS

ITEM TITLE: 1.1 .2 CHEMICAL COMPOSITION DURING PRODUCTION

During the Startup Test Program, the DWPE will attempt, at the same time, to establish the behavior of the melter during larger changes in composition (e.g., going from Purex to HM glass). If it is possible to reliably predict the composition of the glass in individual canisters from feed analyses, this may be substituted for the macro-batch approach. In that case, the uncertainty associated with the prediction would have to be included as a source of error for t re reported composition, and reported in the waste Form Qualification Report.

Estimates ef Error of Reported Compesition

The reported composition will be subject to the following sources of error. Each of these will be characterized during the startup Test Program.

- Feed and sampling variability. Feed non-uniformity and sampling system variability together are estimated to contribute less than 5 relative orror to the reported values. These estimates are based on short-term experimental data using the prototypical DWPF sampler, in a full-scale vessel similar to the Melter Feed Tank. More definitive estimates of the contribution of feed and sampling system variability on the precision and accuracy of the reported composition will be made during the startup Test Program in the DWPE. These results will be reported in the waste Form Qualification Report.

- Variability due to the analytical system. This includes variation in the performance of the analytical methods, and longer-term variations, for example those due to changes in personnel or aging of equipment. Estimates of the precision of the analytical methods themselves are shown in Table 3.200.2. These are based on experimental investigations to confirm the reliability of the methods developed for the DWPE. Standard glasses similar in composition to DWPE glass were analyzed. The reported results reflect only short-term variability. The experiments were performed remotely in SRL's Shielded Cells Facility. The standard glasses were distributed by the MCC. For these, the accepted values listed in the Table were determined by Corning, Inc. for SRI. The errors assoclated with the analytical system are expected to be less than $10 \%$ for most of the elements although elements near the $0.5 \%$ threshold may be known less precisely. More definitive estimates 
WSRC - SW $4-5$

$\operatorname{Par}^{+} 3$

Item 200

Page 8 of 15

Date: $8 / 91$

Revision $1 \mathrm{~B}$

PART ITIE: WASTE FORM SPECIEICATIONS

ITEM TITLE: 1.1 .2 CHEMICAL COMPOSITION DURING PRODUCTION

will be made during the startup Test program, based on character:zation of the capabilities of the DWPE laboratory.

- Error in calculation of macro-batch composition. A preliminar' estimate of the error introduced in determination of the composition of the macro-batch indicates that for expected changes in composition (e.g., going from Batch 1 to Batch 2 - Part 3, Item $100)$, the exror introduced is less than $10 \%$.

- Process variability. Process varlability cannot be determined until experience is gained in actual operation of the facility, during the Startup Test Program. Based on operation of a largescale facility with simulated waste, the predominant source of error may be the variability of the feed in the macro-batch. Samples are currently being characterized to quantify this error. These results will be reported in the Waste Eorm Qualiflcation Report. The variability for any one component attributable to process variations is currently estimated to be less than $10 \%$.

Glass Sampling and Analyses

Glass samples will be taken perlodically during processing of a macro-batch and characterized by SRL. The results will provide confirmatory evidence of control of the product. Characterization of these samples wlll include chemical and radiochemical analyses, and confirmation of durability using the DWPE product Consistency Test (see Part 3, Item 500). The analytical methods used will be the same as those identified for DWPE analysis of vitrified slurry samples. If discrepancies between the glass sample analyses and the reported chemical composition are larger than those which can be attributed to expected errors, the glass will be sampled more frequently to improve the correlation between melter feed and glass.

\section{Startup Test program}

During the Startup Test Program (see Append1x 1.200.3), statist1cally designed tests will be performed to estimate the error in the reported composition. A major goal of the tests will be to determine quantitatively how well the macro-batch average for each element (determined from feed samples) represents the contents of actual canisters of glass. The reported glass composition, based 
WSRC- $\sin 4-6$

eart 3

Item 200

Page 9 of is

Date: $8 / 31$

Revision 13

BART TITLE: WASTE EORM SPECIEICATIONS

ITEM TITLE: 1.1.2 CHEMICAL COMPOSITION DURTNG PRODUCTION

on analyses of feed material, will also be compared to analyses of samples of glass taken from cantsters. Tests will necessarily be short-term (lasting about six weeks each), but attempts will be made to characterize long-term varlabllity as well as short-term, in a statistically defensible manner.

\section{Decumentation}

The Waste Form Qualification Report will descrlbe the sampling system and the analytical methods for determining the glass composition during production. Reports of the results of experimental tests of the methods will also be included. Estimates of the errors due to sampling and analyses from pilot plant testing, testing with simulated feeds in the laboratory and remote testing using radioactive materials will be provided, Determinations of the precision and accuracy of the DWPF laboratory procedures will also be reported.

The Production Record for each canistered waste form will include the elemental composition of the glass. The values reported will. be based on the numerical averages of the individual elemental analyses for all of the process batches corresponding to the macro-batch, expressed as oxides in the glass. The number of samples averaged, and the standard deviations of the analytical values for each element, will also be reported. The reported chemical composition will be the same for all canistered waste forms produced from a given macro-batch of feed. The results from analyses of glass sample(s) taken during processing of the macro-batch will also be reported.

\section{References}

1. D. E. Snyder and D. L. Gunnels, "Remote Operation of Defense Waste Processing Facility Sampling Stations," Rroceedings, 33 rd Conference on Remote Systems Technology, American Nuclear Soctety, 90-93(1985).

2. C. J. Coleman, R. A. Dewberry, A. J. Lethco, C. D. Dennard, "Analytical Methods and Laboratory Facility for the Defense Waste. Erocessing Facility," Proceedings - 28th Oak Ridge National Laboratoxy Conference on Analytical Chemistry, W. R. Laing (ed.), Lewis Publishers, Chelsea, MI, 337-43 (1986). 


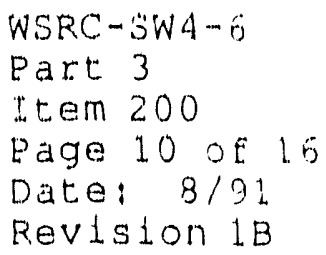

PART TITLE: WASTE EORM SPEUIEICATIONS

ITEM TITLE: 1.1 .2 CHEMICAL COMEOSITION DURING PRODUCTION

3. C. J. Coleman, "Analyses of Nuclear Fuel and High-Level Waste by Inductively Coupled PLasma-emission Spectroscopy, "Analytical spectroscopy, W. S. Lyon (ed.), Elsevier, New York, 195-99 (1985).

4. C. J. Coleman, E. W. Bauman, N. E. Blbler, R. A. Dewberry and E. E. Sturcken, Analysis of Radioactive Wasto and Glass for a Defense Waste Solidification Plant, USDOE Report DP-MS-87-23, E. I. Dupont de Nemours \& Co, Savannah River Laboratory, Alken, SC $29808(1987)$.

5. C. J. Coleman, N. E. Bibler, R. A. Dewberry, "Analysis of High Level Radioactive Glasses and Sludges for the Savannah River Site," Waste Management 90, 2, Roy G. Post (ed.), 651-7 (1.990). 


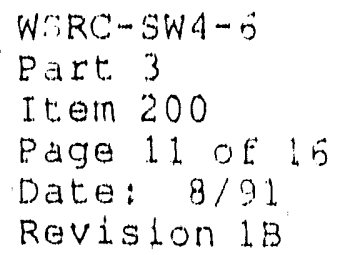

TABLE 3.200.1 Major Elements ( 20.5 wt of of the glass) and Analytical Techniques for Design-Basls DWPE Glass

coropenent

A.

B

Ca

$\mathrm{Fe}$

K

LL

$\mathrm{Mg}$

$\mathrm{Mn}$

$\mathrm{Na}$

$N 1$

S1

Ti.

U
Seurce

Sludge

Erit, salt

Sludge

sludge

Salt

Erit

Erit, sludge

SIludge

Erit, salt, sludge

Sludge

E'rit, sludge

salt

Sludge
Tectondone*

ICP

ICP

ICP

ICP

AA or ICP

ICP

ICP

ICP

ICP

ICP

ICP

ICP

ICP

* ICP = inductively coupled plasma spectroscopy

$A A=$ atomic absorption spectroscopy 


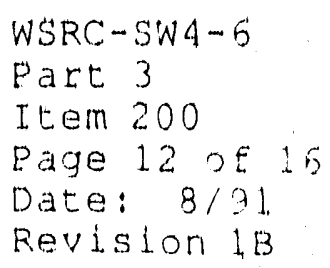

TABLE 3.200.2 Representative Values for Precision and Accuracy of DWPE Analytical Techniques, Based on Analyses of: Glass Standards

\begin{tabular}{|c|c|c|c|}
\hline Component " & $\begin{array}{c}\text { Referenceb } \\
\underline{n}+\mathrm{s}\end{array}$ & $\begin{array}{c}\text { DWPE Methodo } \\
\text { Wt } 8\end{array}$ & $\frac{8}{2 R S Q^{d}}$ \\
\hline $\mathrm{SlO}_{2}$ & 47.9 & 47.5 & 1.8 \\
\hline $\mathrm{Ee}_{2} \mathrm{O}_{3}$ & 14.0 & 14.0 & 0.6 \\
\hline $\mathrm{Na}_{2} \mathrm{O}$ & 11.5 & 11.5 & 1.1 \\
\hline $\mathrm{B}_{2} \mathrm{O}_{3}$ & 8.67 & 8.57 & 3.4 \\
\hline $\mathrm{Li}_{2} \mathrm{O}$ & 3.21 & 3.24 & 3.2 \\
\hline $\mathrm{Al}_{2} \mathrm{O}_{3}$ & 4.73 & 4.62 & 0.59 \\
\hline $\mathrm{K}_{2} \mathrm{O}$ & 2.71 & 2.71 & 1.2 \\
\hline $\mathrm{MnO}_{2}$ & 2.31 & 2.37 & 0.71 \\
\hline $\mathrm{CaO}$ & $1 . .43$ & 1.43 & 0.70 \\
\hline MgO & 0.86 & 0.88 & 0.54 \\
\hline $\mathrm{TLO}_{2}$ & 1.15 & 1.23 & 0.38 \\
\hline $\mathrm{N} 10$ & 1.05 & 1.11 & 0.43 \\
\hline
\end{tabular}

a Components inciluded are specles which are required to be reported for any of the projected compositions in Table 3.100.1. Reference Glass did not contain uranium.

b Average of $36 \mathrm{high}$-prectsion analyses performed by Corndng Engineering Laboratory Services.

c Average of six determinations by SRL, using DWPE methods.

d percent Relative Standard Deviation, based on use of the DWPE method. 


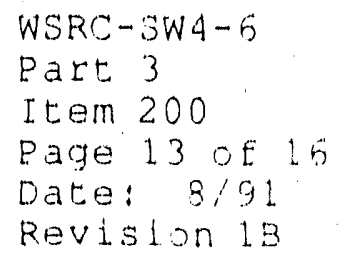

EIGURE 3.200.1 Strategy to Determine Chemical Composition of DNEA G.iass during production.

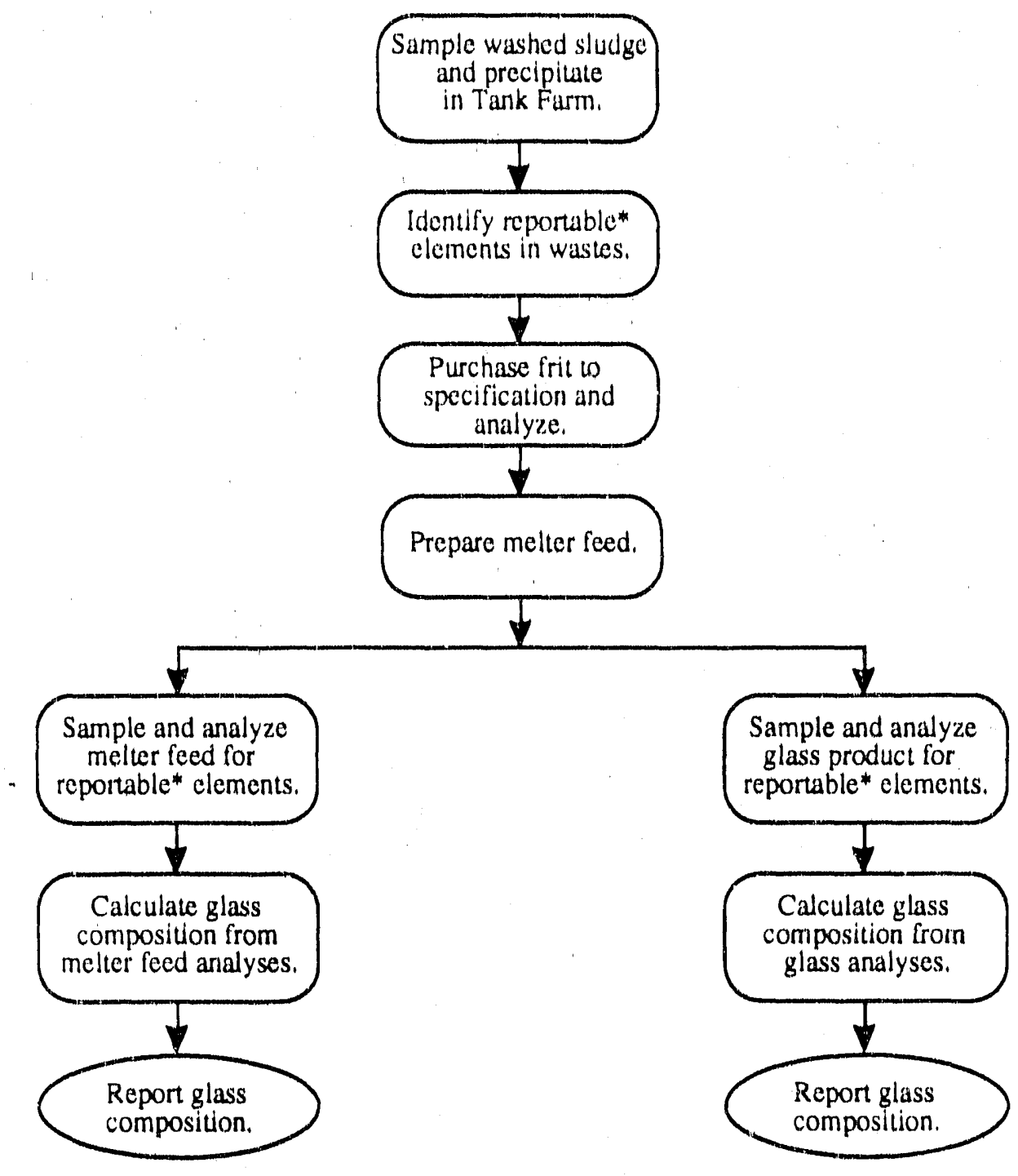

* Elements $\geq 0.5$ weight \% 


$$
\begin{aligned}
& \text { WSRC-SW4-5 } \\
& \text { Part } 3 \\
& \text { Item } 200 \\
& \text { Page } 14 \text { of } 15 \\
& \text { Date: } 8 / 91 \\
& \text { Revision } 1 \mathrm{~B}
\end{aligned}
$$

ElGURE 3.200.2 Tasks planned to satisfy Specification 1.1.2, Chemical composition during Production.

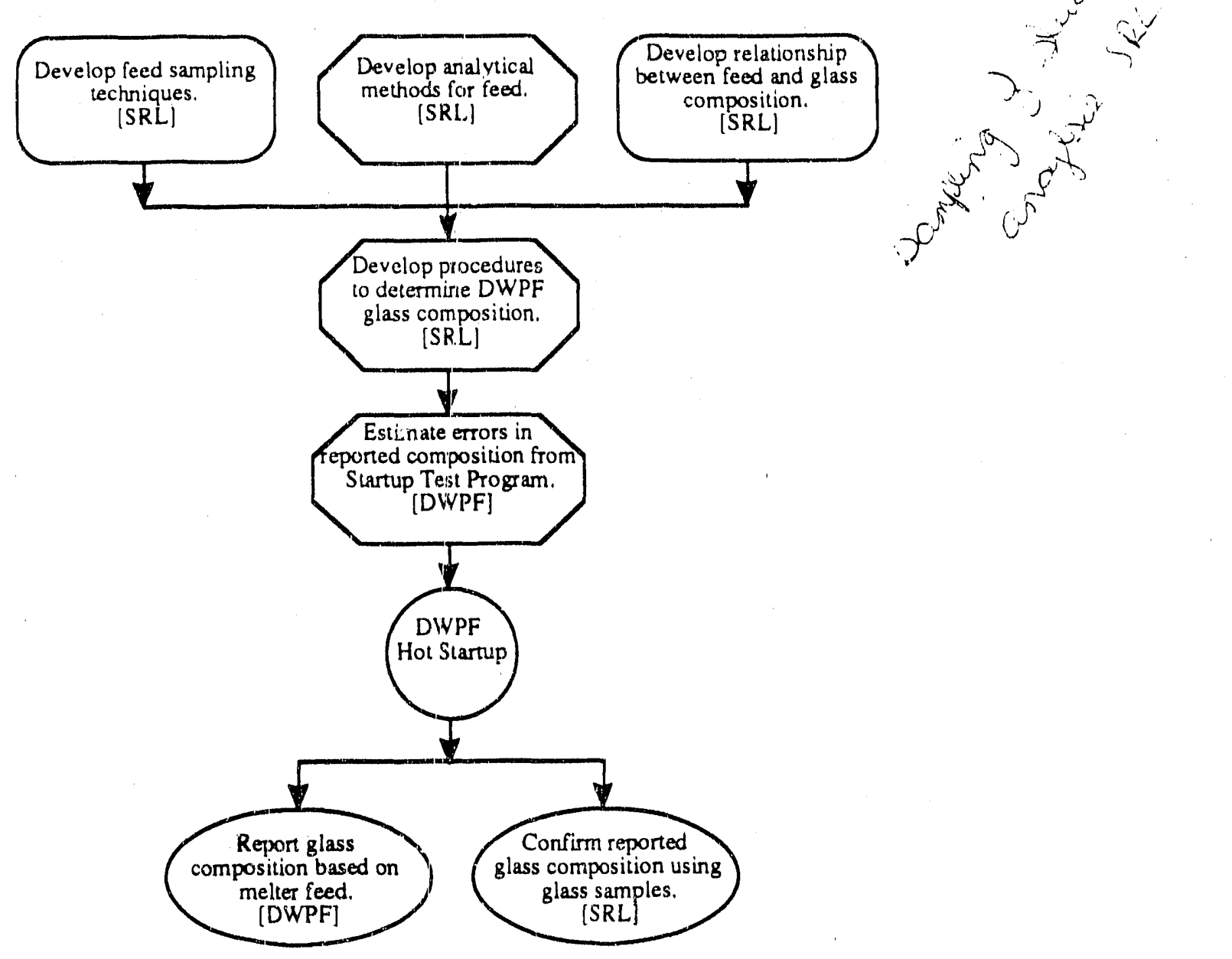


WSRC - SW 4- 6

Part 3

Item 200

Page 15 of 16

Date: $8 / 191$

Revision $1 B$

EIGURE 3.200 .3 DWPE recirculating sample loop.

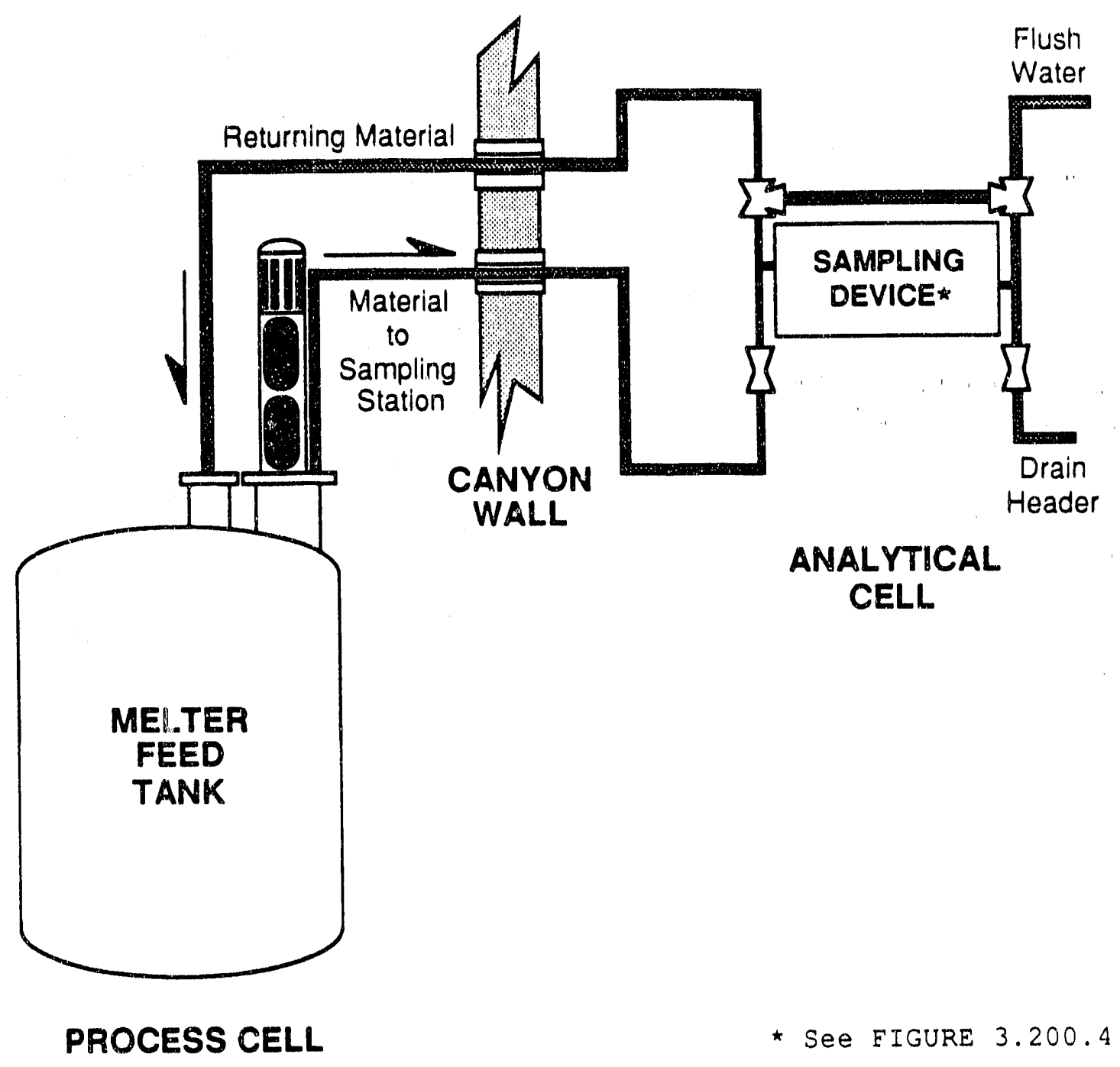




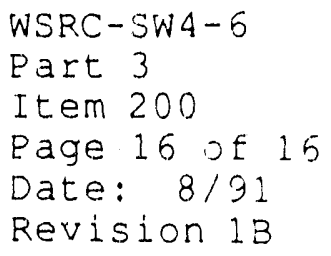

EIGURE 3.200.4 DWPE Remote Sample Valve.

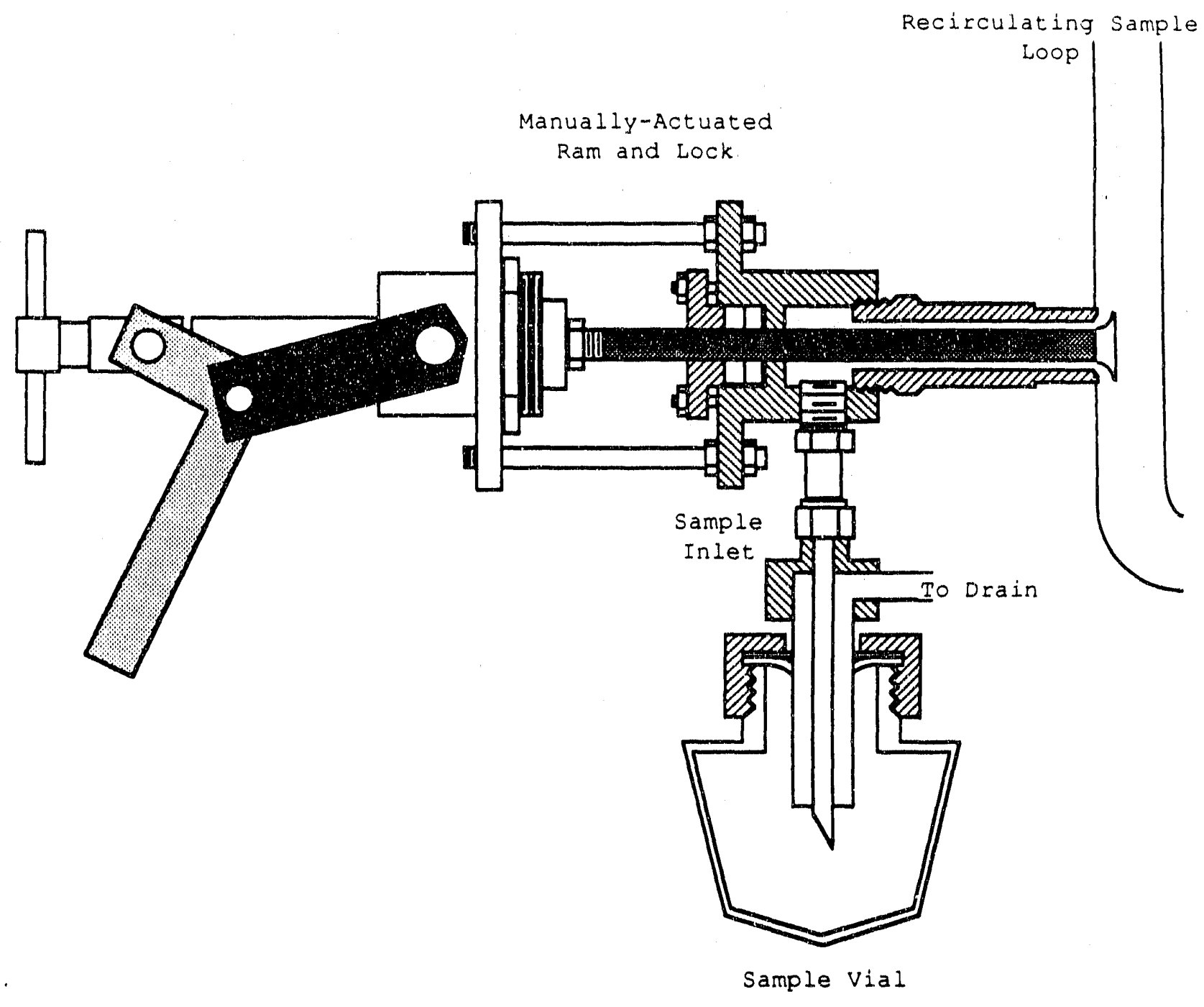




WSRC-SW4-6
Part 3
Item 300
Page 1 of 10
Date: $8 / 91$
Revision 13

PART TITLE: WASTE FORM SPECIEICATIONS

ITEM TITLE: 1.2 .1 RADIONUCLIDE INVENTORY PROJECTIONS

\subsection{RADIONUCLIDE INVENTORY SPECIFICATION}

The producer shall report the estimated inventory of radionuclides (in Curies) that have half-lives longer than 10 years and that are or will be present in concentrations greater than 0.05 percent of the total radioactive inventory for each waste type at any time up to 1100 years after production. The producer shall also report the upper limit of all radionuclides for any canistered waste form. These estimates shall be indexed to the year 2025. The inventory at year 3125 shall also be provided.

\subsubsection{Badienuclide Inyentery Projections}

The producer shall provide in the WOR estimates of the total quantities of individual radionuclides to be shipped to the repository and the estimated error in the values. The producer shall also provide in the WQR estimates of the inventories for each waste type and the estimated error. The method to be used for demonstrating compliance shall be described by the producer in the WCP.

\section{Bationale}

The total radionuclide inventory is required for a determination of the producers' contribution to the repository source term for calculations to show compliance with 10 CFR Part 60 release rate and 40 CFR Part 191 total release standards. A reference year was needed for indexing radionuclide inventory values. The year 2025 was chosen to serve this purpose. Inventory estimates for each canistered waste form are required to confirm that each canistered waste form falls within bounds considered in licensing, safety, and isolation assessments, and for estimates of releases under unanticipated processes and events, and accident scenario conditions.

Estimates of expected variations in radionuclide inventories are necessary to help quantify uncertainties in radionuclide release estimates for repository performance assessments. The minimum concentration of 0.05 percent is needed to ensure that: (a) a reasonably accurate Total Release Rate limit can be calculated; and (b) all radionuclides, whose release rate from the engineered barrier system must be controlled to less than $1 \times 10-5 / y x$, are specifically identified, in accordance with $10 \mathrm{CFR} 60.113$. It also 


$$
\begin{aligned}
& \text { WSRC-SW4-6 } \\
& \text { Part } 3 \\
& \text { Item } 300 \\
& \text { Page } 2 \text { of } 10 \\
& \text { Date: } 8 / 91 \\
& \text { Revision } 1 \text { B }
\end{aligned}
$$

PART TIRE: WASTE EORM SPECIEICATIONS

ITEM TITLE: 1.2 .1 RADIONUCLIDE INVENTORY RROJECTIONS

\begin{abstract}
provides a reasonable lower bound for assessment of releases during accidents.
\end{abstract}
The half-life criterion needs to be as low as 10 years so that "pre-closure" exposure and accident concerns can be addressed. The upper limit values for all radionuclides are needed to address transportation requirements.

The 1100 years is based on a 1000 year containment period plus 100 years after production for storage, transportarion, and operation prior to repository closure, and will be used as the basis for calculating the inventory for the 10 CER 60.113 release rate criterion.

\title{
Compliance strategy
}

The DWPE Design-Basis waste glass will be used to identify the set of radionuclides to be reported. Estimates of the quantities of individual radionuclides in each of the waste types which will actually be vitrified in the DWPE (Batches 1 - 4, see Part 3, Item 100) will also be developed. Estimates of the total quantities of individual radionuclides in DWPE glass will be based on the sum of the inventories of individual radionuclides currently stored in the waste tanks, and on anticipated future waste generation at SRS. For the latter, the radionuclide inventory of the DesignBasis glass will be assumed. Estimates of the errors in the estimated values will be reported, including comparisons between the projections and samples of actual waste and glass. It is anticipated that the reported values will be upper bounds for the inventory of radionuclides in actual production glass. Each reported value wi.l be indexed to both 2025 and 3125 .

\section{Implementation}

The tasks planned to satisfy this specification are outlined in Eigure 3.300.1. These tasks are:

- Development of the radionuclide inventory for the Design-Basis glass. The Design-Basis glass represents a bounding case in terms of the dose rate, and heat generation rate, expected from DWPE canistered waste forms. 
WSRC - SW $4-5$

Part 3

Item 300

Page 3 of 10

Date: $8 / 91$

Revision $1 \mathrm{~B}$

PART TITLE: WASTE EORM SPECIEICATIONS

ITEM TITLE: 1.2 .1 RADIONUCLIDE INVENTORY PROJECTIONS

- Use of the radionuclide inventory of the Design-Basis glass to identify the set of radionuclides whose inventory must be reported.

- Identification of the amounts of individual radionuclides in waste currently stored in the Tank Earm. As of December 31, 1990, it was estimated that the high-level waste (HLW) tanks at SRS contained 34,784,000 gallons of waste. 1 The curie content of the current waste inventory, as estimated by Ir.terim Waste Management (IWM, the organization responsible for management of HLW in the Tank Earms at SRS), is listed in Table 3.300.1.

- Identification of the waste types for waste currently stored at jRS. As discussed in Part 3, Item 100, these waste types correspond to the sludge batches in the Tank Farm, and their associated batches of precipitate.

- Estimation of the number of canisters produced in the future by SRS. This estimate will include future waste generation at SRS, as well as recycle from the DWPE.

- Estimation of the amount of radionuclides for each waste type. For future waste, the Design-Basis composition will be used, as a conservative upper bound.

- Estimation of the errors in the projections.

Design-Basis Radionuclide Inventory

Using the radionuclide inventory of the Design-Basis waste (Part 1, Item 300), and the integrated flowsheet model for the DWPE (Part 3, Item 100), the radionuclide inventory of the Design-Basis glass has been developed. This inventory has been used as the basis for biological shielding, process cooling, and environmental release requirements for the DWPE. Several assumptions were made in developing the design basis radionuclide inventory.

- A standard blend of waste streams containing various radionuclides was developed, and assumed to be the constant input to the DWPE. 
WSRC-SW4-6

Part 3

Item 300

Page 4 of 10

Date: $8 / 91$

Revision $1 \mathrm{~B}$

PART TITLE: WASTE EORM SPECIEICATIONS

ITEM TITLE: 1.2 .1 RADIONUCLIDE INVENTORY, PROJECTIONS

- Insoluble waste (sludge) is aged five years to decay shortlived isotopes.

- Soluble waste (feed for precipitation process) is aged 15 years, primarily to assure low concentrations of Ru-106.

\section{Badionuclides to be Reported}

The radionuclide inventory of the Design-Basis glass includes projections of the amounts of individual radionuclides as a function of time after production of the glass. Table 3.300.2 l1sts all of the radionuclides, with a half life greater than ten years, which comprise at least 0.018 of the racionuclide inventory (in curies) of the Design-Basis glass at any time up to 1100 years after production. This is the set of radionuclides which will be reported under this specification. The selection of the 0.01 o limlt is discussed in more deta11. in Part 3, Item 400 . Use of this more inclusive limit ensures that all required radionuclides are reported for compliance with this specification.

\section{Badienuclide Inventory of current Waste}

The waste types designated Batches 1 - 4 in Part 3, Item 100, will be assumed to be the waste types comprising current waste, for purposes of compliance with this specification. For each waste type, the total radionuclide inventory for that waste type will. depend on the amounts of individual radionuclides per unit mass of each waste type, and the total amount of each waste type in the SRS Tank Earm.

The information sources which will be used to identify the amounts of individual radionuclides for each waste type will include the results generated by computer codes based on radionuclide production, analytical data from waste samples, and results from the DWPE flowsheet calculations (see Part 3, Item 100). Avallable data from all of the radionuclide inventory sources will be compared to assure that the most reasonable values are used for each individual radionuclide. If a good technical basis for choosing one value over another cannot be established, the most conservative value will be chosen. As discussed in Part 3, Item 100, waste blending schemes developed by IWM will be used to develop radionuclide inventory estimates for current waste. 


WSRC $-S W 4-5$
Part 3
Item 300
Page 5 of 10
Date: $8 / 91$
Revision 1.B

PART TITLE: WASTE EORM SPECIEICATIONS

ITEM TITLE: 1.2 .1 RADIONUCLIDE INVENTORY PROJECTIONS

The total amount of each waste type w1.1 be estimated based on the volume of the sludge, and a factor to convert from waste volume to mass. The mass of each waste type will then be used to determine the total number of canisters to be produced from each waste type.

Euture Waste

The radionuclide inventory of the Design-Basis glass will also be used to project the radionuclide content of waste to be generated in the future. SRS production forecasts w111 be used to project the amount of waste to be generated in the future (and, thus, the number of canistered waste forms to be produced in the DWPE). Since the composition of waste to be generated in the future is not known, the Design-Basis radionuclide inventory will be assumed for future waste.

Predicting isotopic content of waste that has not yet been generated with any degree of certainty is not possible. However, if the assumptions made about future waste generation are correct, current experience indicates that measured radionuclide inventories will be within $25 \%$ of those predicted from standard radionuclide generation computer codes.

\section{Total Amount of Individual Radionuclides to DWRE Glass}

The total amount of individual radionuclides in projected DWPE glasses will be calculated by adding the amount of each radionuclide in all of the canisters of each waste type for current waste to the amount of that radionuclide assumed to be produced in the future.

\section{Estimation of Errors in the projections}

The specification requires that the DWPE estimate the error in the projected radionuclide inventory for each waste type, and for the total radionuclide inventory.

The profected radionuclide inventory for each waste type will be subject to the following sources of error: uncertainty in the amount of each radionuclide in a given waste type, error in the volume of that waste type, and error in the assumed mass of waste 
WSRC $-3 W 4-6$

Part 3

Item 300

Page 6 of 10

Date: $8 / 91$

Revision $1 B$

PART TITLE: WASTE EORM SPECIEICATIONS

ITEM TITLE: 1.2 .1 RADIONUCLIDE INVENTORY PROJECTIONS

per unit volume. The WQR will provide estimates of each component of error. Based on current information, the largest source of error is the uncertainty in the amount of each radionuclide in a given waste type.

Since the total amount of each radionuclide will be calculated as the sum of the amount in each waste type for current waste and the amount in future waste, it will be subject to each of the errors listed above. In addition, the assumption listed above for future waste generation will also introduce error in the total. The magnitude of each of these errors will also be estimated in the WQR.

When samples are taken of waste and glass from the 1 nitial feed to the DWPE (Batch 1), the content of the radionuclides listed in Table 3.300 .2 for the waste and glass samples will be compared to the projections. These will provide confirmation of the projected radionuclide inventories.

eualification of Euture Waste Glass Compositions

Because the radionuclide inventory of the Design-Basis glass was the basis for design of blological shielding for the DWPE, and for design of the cooling system for the Glass waste storage Building, it represents an upper bound expected for all DWPF canistered waste forms. If future wastes would produce glasses which exceed these properties, the DWPF proposes to apply Eart 6, Item 200, in the following manner.

- A determination will be made of whether the new waste composition will produce a glass with different properties (dose rate, or heat generation rate) than represented by the set of projected compositions. The repository program will be notified in writing of the results of that determination. If the properties of the new glass are bounded by the set of projected compositions (from above), the DWPE will propose to update the WQR to include the new composition, but will propose that no further action be taken. If the waste will produce a glass with properties outside the range of tho: 2 already projected, then the DWPE will propose activities to ensure that the waste produces a glass which complies with specifications.

- Once agreement is reached with the repository program on appro- 
WSRC $-3+N 4-5$

Part 3

Item 300

Page 7 of 10

Date: $8 / 91$

Revision $1 B$

PART TITLE: WASTE EORM SPECIEICATIONS

ITEM TITLE: 1.2 .1 RADIONUCLIDE INVENTORY PROJECIIONS

priate actions, they will be carried out, and the WQR revised to reflect their results.

\section{Recumentation}

The Waste Eorm Qualification Report (WQR) will provide estimates of the total quantities of radionuclides expected to be made into borosilicate waste glass at DWPE, as well as estimates of the quantities of individual radionuclides expected to be present in the canistered waste forms to be produced from each waste type. Estimates of the errors of these profections will be provided in the WQR. These projections w111 be indexed to both 2025 , and 3125. Verification of these projections, through comparison to analyses of actual waste and glass, will also be included in the WQR.

\section{Beference}

1. Oak Ridge National Laboratory, Integrated Data Base for 1990: Spent ruel and Radioactive Waste Inventories, projections, and Charactaristics, USDOE Report RW-0006, Revision 6, U. \$. Department of Energy, Washington, DC (1990). 


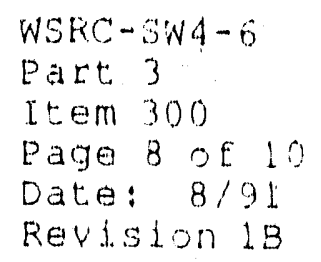

TABLE 3.300.1 SRS HIgh-Level. Waste Elssion Product Inventori' as of December $31,1990 . *$

Tutal volume of waste, $\mathrm{m}^{3}$ (gals):

Total Activits, $10^{6} \mathrm{Cl}$ :

Total fission product activity 1 n Tank Earm

(Major species are $S r-90 / Y-90$, and

Cs $-137 / \mathrm{Ba}-137 \mathrm{~m}$, each $46 \%$ of curle content)

Total actinide activity in Tank Farm

(Major species are pu-238, 53 of curles; and Pu-241, 46\% of curles)

Total heat output, $\mathrm{kW}$ :

Total heat from fission products

Total heat from actinides

* Values based on estimates from IWM. 
WSRC-SWA-

part 3

Item 300

E'age of 10

Date: $8 / 91$

Reviston LB

TABLE 3.300.2 Radionuclides to be Included in profected radionuclide inventories . *

BADLONUCLIDE

$N 1-59$

$N 1-63$

Se -79

$\mathrm{Sr}-90$

$2 r \cdots 93 / \mathrm{Nb}-93 \mathrm{~m}$

TC- 99

$P d-107$

Sn-126

Cs -135

Cs -1.37

$\mathrm{Sm}-151$

$T h-230$

$U-234$

U- -238

$\mathrm{Np}-2.37$

Pu-238

Pu-239

Pu-240

Pu-241

Pu-242

Am-2 1

Am-243

$\mathrm{Cm}-2.44$

\section{REASON EOR_RERORTING}

$>0.01 \%$, for all t>400 years

$>0.01 \%$, for a 11 t $>200$ years

$>0.01$ \& for all $t>200$ years

$>0.01 \%$, for all $t<500$ years

$>0.01 \%$ for all t> 200 years

$>0.01 \%$, for all $t>80$ years

$>0.01 \%$, for a.l $t>500$ years

$>0.01 \%$, for all t. $>2.00$ years

$>0.01 \%$, for all $t>300$ years

$>0.01$ \%, for a $11 t<700$ years

$>0.01 \%$, for all $t$

$>0.01 \%$, for all $t>1000$ years

$>0.0 .1 \%$, for ald $t>200$ years

$>0.01 \%$, for all t $>500$ years

$>0.01 \%$, for al1 $t>500$ years

$>0.01$ \%, for allt

$>0.01 \%$, for al1 $t>45$ years

$>0.01 \%$, for all $t>45$ years

$>0.01$ \% for a $1 . \mathrm{t} t>200$ years

$>0.01 \%$, for ald t $>500$ years

$>0.01 \%$, for all $t>45$ years

$>0.01 \%$, for all $t>800$ years

$>0.01$, for a $11 \mathrm{t}<100$ years

* $\tau_{1 / 2}>10$ years, concentration $>0.01$ \& of the total curle inventory of the design-basig glass at any time up to 1100 years. 
WSRC-SW4-5

Pate 3

It.em 300

Page 10 of 10

Date: $8: 9$ !

Revision 18

EIGURE 3.300.1 Tasks planned to satisfy speolfication 1.2.1, Radionuclide Inventory Projections.

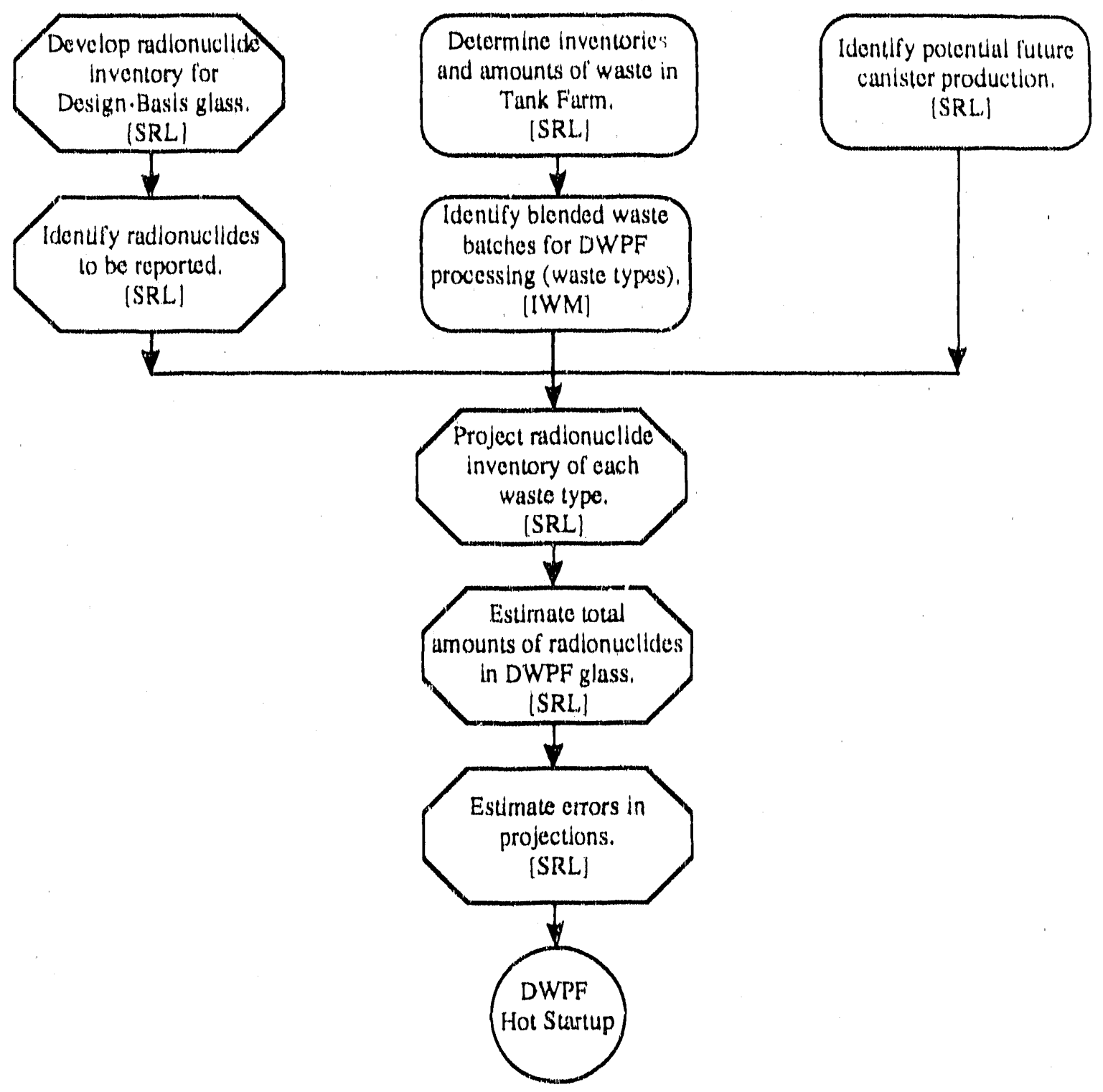


PAFT TITLE: WASTE FORM SPECIEICATIONS

ITEM TITLE: 1.2 .2 RADIONUCLIDE INVENTORY DURING PRODUCTION

\subsubsection{Badionuchide Inventery Durina Production}

The producer shali provide in the production Records estimates of inventories of individual radionuclides in each waste type. The producer shall also report the estimated error of these estimates in the WOR.

\section{Bationale}

The total radionuclide inventory is required for a determination of the producers' contribution to the repository source term for calculations to show compliance with 10 CFR Part 60 release rate and 40 CF'R Part 191 total release standards. A reference year was needed for indexing radionuclide inventory values. The year 2025 was chosen to serve this purpose. Inventory estimates for each canistered waste form are required to confirm that each canistered waste form falls within bounds considered in licensing, safety, and isolation assessments, and for estimates of releases under unantioipated processes and events, and accident scenario conditions.

Estimates of expected variations in radionuclide inventories are recessary to help quantify uncertainties in radionuclide release estimates for repository performance assessments. The minimum concentration of 0.05 percent is needed to ensure that: (a) a reasonably accurate Total Release Rate limit can be calculated; and (b) all radionuclides, whose release rate from the engineered barrier system must be controlled to less than $1 \times 10^{-5} / \mathrm{yr}$, are specifically ldentified, in accordance with $10 \mathrm{CrR} 60.113$. It also provides a reasonable lower bound for assessment of releases during accidents.

The half-life oxiterion needs to be as low as 10 years so that "pre-closure" exposure and accident concerns can be addressed. The upper limit values for all radionuclides are needed to address transportation roquirements.

The 1100 years is based on a 1000 year containment period plus 100 years aftar production for storage, transportation, and operation prior to repository closure, and will be used as the basis for calculating the inventory for the $10 \mathrm{CFR} 60.113$ release rate cri- 
WSRC-SW $4-6$

Part 3

Item 400

Page 2 of 14

Date: $8 / 91$

Revision $1 B$

PART TITLE: WASTE EORM SPECIEICATIONS

ITEM TITLE: 1.2.2 RADIONUCLIDE I'VENTORY DURING PRODUCTION

tarion.

compliance Strategy.

The strategy for determining the rauionuclide inventory of DWPE glass (shown in Eigure 3.400.1) is similar to that for the chemical composition during production (Part 3, Item 200). It is based on the relatively constant nature of the sludge feed to the DWPE over the life of each Tank Farm sludge batch, and of the precipitate feed over the life of each Tank Farm precipitate batch ( 4 months). Thus, for purposes of compliance, a macro-batch constitutes a waste type.

The DWPE will report the contents of all radionuclides listed in Table 3.300 .2 as the radionuclide inventory of the glass. Each of. these radionuclides has a half-life > 10 years. Each makes up at least $0.01 \%$ (on a curie basis) of the radionuclide inventory of the Design-Basis glass at some time between the time of production of the glass and 1100 years after production. The DWPE has chosen to report this fixed set of species because of the difficulty of determining which radionuclides will constitute 0.05 o at some time up to 1100 years after production, for a specific macrobatch. By choosing a more stringent limit (0.018), the DWPE ensures that all radionuclides which might be included are actually reported.

For those radion.clides which can be measured directly in the DWPE laboratory, the concentration of each in the feed to the melter will be measured in samples from each process batch. The average concentration of each measured radionuclide over the macro-batch will be reported in the production Records.

For those radionuclides which cannot be determined directly in the DWPE, an indirect approach will be used. Samples of the waste in the Tank Earm will be taken from each sludge and precipitate batch which constitute the macro-batch. The concentrations of the specified radionuclides in the individual waste streams will then be determined. These analyses will be used to develop correlations between these radionuclides, and species which are chemically similar, and can be measured directly in the DWPE laboratory. The methods to be used for each radionuclide are listed in Table 3.400.1. Analyses of samples of waste from the Tank Earms will 
WSRC $-S W 4-5$

Part 3

Item 400

Page 3 of 14

Date: $8 / 91$

Revision $1 B$

PART TITLE: WASTE EORM SPECIEICATIONS

ITEM TITLE: 1.2 .2 RADIONUCLIDE INVENTORY DURING PRODUCTION

also be used to establish estimates of the errors of the DWPE methods, which will be reported in the Waste Form Qualification Report.

During production, estimates of the inventories of individual radionuclides in each canistered waste form will be based on the radionuclide inventory in the melter feed. Eor each canistered. waste form produced from a macro-batch, the reported inventory will correspond to the average of the analyses from all process batches in the macro-batch.*

The analytical methods will be demonstrated in SRL's Shielded Celis Facility before radioactive operations begin in the DWPE. Initial estimates of the errors of the methods, and their detection limits, will be made based on these demonstrations, and reported in the Waste Eorm Qualification Report. The accuracy of the reported radionuclide inventory will be periodically confirmed by analyses of glass samples taken from the molten glass stream as it pours into the canister.

\section{Implementation}

The tasks planned to satisfy this specification are outlined in Eigure 3.400.2. These are:

- Development of analytical methods for each of the radionuclides listed in Table $3.300 .1 .1-4$

- Conversion of the analytical methods into DWPE laboratory procedures, for those radionuclides which can be measured directly in the DWPE.

- Development of methods to calculate the concentration of those radionuclices which cannot be measured directly in the DWPE.

* If a radionuclide cannot be detected in either the feed to the melter, or in samples from the Tank Farm, then its content will be reported as "Below Detection Limits." 
WSRC-SW4- 5

Part 3

Item 400

Page 4 of 14

Date: $8 / 91$

Revision $1 \mathrm{~B}$

\section{PART TITLE: WASTE EORM SPECIEICATIONS}

\section{ITEM TITLE: 1.2 .2 RADIONUCLIDE INVENTORY DURING PRODUCTION}

- Estimation of the errors in the reported radionuclide inventory. This includes determination of the errors of those radionuclides which can be measured directly in the DWPE, and of those which will be reported on an indirect basis.

\section{Analysis of Feed Material in the DWPE}

SRL is developing analytical methods for the specified radionuclides. 1 The basis for reporting each radionuclide (Table 3.400.1) depends on its absolute activity level, and its activity relative to other species which might interfere with its detection. Thus, the basis for reporting was chosen so that the reliability of the value reported would be as high as possible.

Some radionuclides can be most reliably reported based on direct measurement in the DWPE. In these cases, the Prodiction Records will contain the averages of the measured values for the macrobatch, and the standard deviations of those values. An example of this is Cs-137, which will be reported based on measurements made on samples of melter feed material by the DWEF laboratory.

In the Waste Form Qualification Report, each of the analytical methods will be described. Demonstrations of their application to synthetic radioactive samples and actual radioactive waste samples will also be reported. The latter studies will establish the minimum error which can be expected from application of these methods to DWPE feed materials, in practice.

\section{Development of Facility-Specific Analytical Procedures}

The DWPE is currently evaluating (and modifying, as necessary) each of the analytical methods proposed for use in the DWPE laboratory. This includes those methods developed for determination of the concentration of radionuclides in each process batch. As each method is adapted to the specific equipment and layout of the DWPE laboratory, detailed procedures for its use and control are also developed. Estimates of the error in the actual application of the procedures will be determined as part of the startup Test program (but after the start of radioactive operations), and reported in the Waste Form Qualification Report. 
WSRC-SW $4-6$

Part 3

Item 400

Page 5 of 14

Date: $8 / 91$

Revision $1 \mathrm{~B}$

PART TITLE: WASTE EORM SPECIFICATIONS

ITEM TITLE: 1.2 .2 RADIONUCLIDE INVENTORY DURING PRODUCTION

Development of Methods for Species Not Measured Direct ix in DNPE

Some radionuclides which are present in low concentrations can be measured with greater reliability in samples of waste from the Tank Farms, compared to analysis of samples of melter feed. SRL is currently developing methods for analysis of these radionuclides. In these cases, the content of these radionuclides will be reported based on a ratio between the radionuclide in question and a species which can be reliably measured in the DWPE (see Table 3.400.1). As an example, $\mathrm{Ni}-6.3$ will be measured on samples of waste from the Tank Earms, and a : tio established between it and total nickel, or iron. The reported $\mathrm{Ni-63}$ value will then be the species in the melter feed actually measured (Ni or Fe) multiplied by the ratio from the Tank Farm samples.

In the Waste Eorm Qualification Report, each of the analytical methods and calculational techniques will be described. Demonstrations of their application to synthetic radioactive samples and actual radioactive waste samples will also be reported. The latter studies will establish the minimum error which can be expected from application of these methods in practice.

\section{Feed to Glass correlation}

During production, the composition of canistered waste forms produced during processing of a macro-batch will be reported as the average of the analyses of all the feed batches produced from that macro-batch. This introduces an error by neglecting the heels from previous batches left in process vessels. The magnitude of this error will be determined during the startup Test Program.

During the Startup Test Program, the DWPE will attempt, at the same time, to establish the behavior of the melter during larger changes in composition (e.g., going from Purex to HM glass). If it is possible to reliably predict the composition of the glass in individual canisters from feed analyses, this may be substituted for the macro-batch approach. In that case, the uncertainty associated with the prediction would have to be included as a source of error for the reported composition, determined during the Startup Test Program, and reported in the Waste Form Qualification Report. 
WSRC-SW $4-5$

Part 3

Item 400

Page 5 oE 14

Date: $8 / 91$

Revision $1 B$

PART TITLE: WASTE EORM SPECIFICATIONS

ITEM TITLE: 1.2.2 RADIONUCLIDE INVENTORY DURING PRODUCTION

Estimates of Error of Beported Radionuclide Inventery

The reported radionuclide inventory will be subject to each of the sources of error identified in Part 3, Item 200, for determination of the chemical composition of the glass. Each of these will be characterized during the Startup Test Program, or during initial DWPE operations.

- Eeed and sampling variability. This is discussed in part 3, Item 200 .

- Variability due to the analytical system. This includes variation in the performance of the analytical methods, and longer-term variability due to, e.g., changes in personnel or aging of equipment. Estimates of the precision and bias of several of the methods are shown in Table 3.400.2, based on round robin testing conducted by the Materials Characterization Center. The data include only short-term variations. The errors associated with the analytical system are expected to be less than 10\%, for all of the measured species. However, for species which may partially vola-tilize during sample preparation, the error may be greater, 1020\%. For other species, in particular those which cannot be measured directly within the DWPE, the errors are likely to be much greater. Definitive estimates will be made after initial radioactive operations, based on characterization of the actual analytical system.

- Errers in calculation of macre-batch radionuclide inventery. A preliminary estimate of the errors thus introduced in determination of the radionuclide inventory of the macro-batch indicates that for expected changes in composition (e.g., going from Batch 1 to Batch 2 - see Part 3, Item 100), the error may be on the order of $25 \%$.

- Errersincerrelation functions. At the present time, the precision and accuracy of the correlations between measured species and unmeasured radionuclides are not known. An estimate will be developed based on work which will be performed on the initial feed to the DWPE in SRL's Shielded Cells Facility. This will be reported in the Waste Form Qualification Report.

- Rrecessvariability. In addition to the process variability 
WSRC-SWA-6

Part 3

Item 400

Page 7 of 14

Date: $8 / 91$

Revision 18

PART TITLE: WASTE EORM SPECIEICATIONS

ITEM TITLE: 1.2 .2 RADIONUCLIDE INVENTORY DURING PRODUCTION

discussed in Part 3, Item 200, variablitty in the amount of glass in the canister is an source of error in the reported radionuclide inventory. Based on the design criteria for the weight systems for the DWPE, this should contribute less than 28 to the total uncertainty. Errors due to process varlability cannot be determined until experience is gained in actual operation of the factlity, during the startup Test Program. These results will be reported in the Waste Form Qualification Report.

\section{Giass Sampling and Analyses}

Glass samples will be characterized periodically during processing of a macro-batch to provide confirmatory evidence of control of the product. When glass samples are taken in the DWPE, they will be sent to SRL for chemical and radiochemical analyses, and confirmation of durability using the DWPE Product Consistency Test (See part 3, Item 500). These results will be used to confirm, and if necessary refine the correlations used for reporting radionuclide inventory. If discrepancies between SRL glass sample analyses and the reported radionuclide inventory calculated from DWPE process batch sample analyses are larger than those which can be attributed to expected errors, the glass will be sampled more frequently to improve the correlation between melter feed and glass. During initial radioactive operations in the DWPE, more frequent sampling of DWPE glass is likely in order to ensure that any phenomena dependent on the actual melter design and operation (e.g. volatilization) have been properly accounted for in the calculation of the radionuclide inventory.

\section{Decumentation}

The Waste Form Qualification Report will include a report on the methods to be used to determine the radionuclide inventory during production. The precision and accuracy of the methods used, based upon demonstrations in SRL's shielded Cell Facility, and analyses of samples from the Tank Earm, will also be reported. The Waste Eorm Qualification Report will also contain estimates of the errors of calculational algorithms used.

The production Record for each canistered waste form will include estimates of the content of each radionuclide listed in Table 3.400.1. For all radionuclides, the reported inventory for each 


WSRC $-5 W 4-5$
Part 3
Item 400
Page 8 of 14
Date: $8 / 91$
Revision 13

PART TITLE: WASTE EORM SPECIEICATIONS

ITEM TITLE: 1.2 .2 RADIONUCLIDE INVENTORY DURING PRODUCTION

will be expressed as curies per unit mass of glass, and will be reported as a single value for the entire macro-batch.

\section{Beferences}

1. C. J. Coleman, R. A. Dewberry, A. J. Lethco, C. D. Denard, "Analytical Methods and Laboratory Eaclitity for the Defense Waste Processing Eacility," Proceedings - 28th Oak Ridge National Laboratory Conference on Analytical Chemistry, W. R. Laing (ed.), Lewis Publishers, Chelsea, MI, 337-43 (1986).

2. N. E. Bibler, "Leaching Fully Radioactive SRP Nuclear Waste Glass Tuff Ground-Water in Stainless Steel Vessels, "Advances in Ceramics - Nuclear Waste Management, 8, W. A. Ross and G. G. Wicks (wds.), 619-626 (1.986).

3. C. J. Coleman, E. W. Bauman, N. E. Blbler, R. A. Dewberry and E. F. Sturcken, Analysis of Radioactive Waste and Glass for a Defense Waste Solidification plant, USDOE Report DP-MS-87-23, E. I. DuPont de Nemours \& Co., Savannah River Laboratory, Aiken, SC 29808 (1987).

4. C. J. Coleman, N. E. Bibler, R. A. Dewberry, "Analysis of High Level Radioactive Glasses and Sludges for the Savannah River

Site," Waste Management 90, 2, Roy G. Post (ed.), 651-7 (1990). 


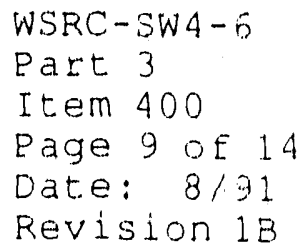

TABLE 3.400.1 Basis for Reporting Concentration of Specific Radionuclides in DWPE Glass (Analytical techniques subject to change based on advances in technologyl.

RADIONUCLIDE

BASIS EQR BEPORTING

$N 1-59$

Measure Ni-59 in Tank Earm samples, using separation/ICP-MS; calculate ratio to measurablea spectes; multiply by content of measurable species

$\mathrm{Ni}-63$

Measure $\mathrm{Ni}-63$ in Tank Earm samples, using separation/ $\beta$-counting; calculate ratio to measurablea species; multiply by content of measurable species

$\mathrm{Se}-79$

Measure Se-79 in Tank Farm samples, using separation/ $\beta$-counting; calculate ratio to measurablea species; multiply by content of measurable species

$\operatorname{Sr}-90$ Separation/ $\beta$-counting in DWPE

$\mathrm{Zr}-93 / \mathrm{Nb}-93 \mathrm{~m}$

Measure $\mathrm{Zr}-93$ and $\mathrm{Nb}-93 \mathrm{~m}$ in Tank Earm samples, using separation/ICP-MS; Calculate ratio to measurable species; multiply by content of measurable species

TC-99

Measure 'Tc-99 in Tank Farm samples, using separation/ $\beta$-counting; calculate ratio to measurable species; multiply by content of measurable species

$P d-107$

Measure Pd-107 in Tank Earm samples, using separation/ $\beta$-counting or ICP-MS; calculate ratio to measurablea species; multiply by content of measurable species 


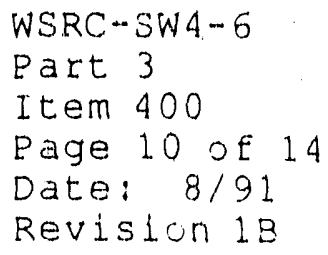

TABLE 3.400.1 Basis for Reporting Content of Specific Radionuclides in DWPE Glass, (Continued)

$S n-126$

Cs -1.35

Cs -137

$S m-151$

Th -230

$\mathrm{U}-234$

$u-238$

$\mathrm{Np}-237$
Measure Sb-126 in Tank Earm samples, using separation/ $\gamma-$-PHA; calculate ratiob to measurablea species; multiply by content of measurable specles

Measure Cs-135 in Tank. Earm samples, using separation/ICP-MS; calculate ratio to measurablea species; multiply by content of measurable spectes

$\gamma$-PHA in DWPE

Measure Sm-151 in Tank Earm samples, using separation/ICP-MS or $\beta$-counting; calculate rat io to measurablea species; multiply by content of measurable species

Measure Th-230 in Tank Earm samples, using separation/ICP-MS; calculate ratio to measurablea species; multiply by content of measurable spectes

Measure U-234 in Tank Earm samples, using separation/ICP-MS; calculate ratio to measurablea species; multiply by content of measurable spectes

\section{Chemical analysis by I.CE in DWPE}

Measure Np-237 in Tank Earm samples, using separation/ICP-MS; calculate ratio to measurablea species; multiply by content of measurable species 


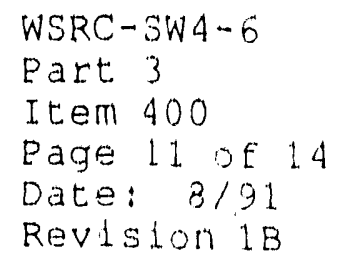

TABLE 3.400.1 Basis for Reporting Content of Specific Radionuclides in DWPE Glass. (Continued)

Pu-239, 240, 241, 242

Measure Pu 1sotopes in Tank Earm samples, using separation/ICP-MS; calculate ratio to measurable species; multiply by content of measurable species

$A m-241$

Measure Am-241 in Tank Farm samples, using separation/ $\gamma$-PHA; calculate ratio to measurablea species; multiply by content of measurable species

$A m-243$

Measure Am-243 in Tank Earm samples, using separation/ $\gamma-\mathrm{PHA}$; calculate ratio to measurable specles; multiply by content of measurable species

$\mathrm{Cm}-244$

Measure Cm-244 in Tank Earm samples, using separation/ICP-MS or $\alpha$-PHA; calculate ratio to measurabled species; multiply by content of measurable species

a Directly measurable in DWPE.

b sn-126 in secular equilibrium with Sb-126; activity assumed to be the same. 


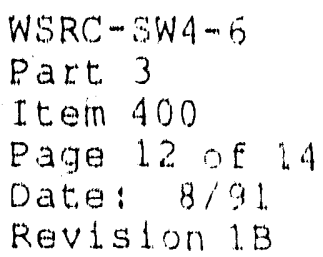

TABLE 3.400.2 Application of Analyt1cal Methods Developed for: DWPE to Determination of Radionuclide Concentrations in Standard Solutions.

\begin{tabular}{|c|c|c|c|}
\hline emponent & $\begin{array}{c}\text { Reference } \\
4 \mathrm{Ci} / \mathrm{mL}\end{array}$ & $\begin{array}{c}\text { DWPE Methodb } \\
4 C 1 / \text { LI }\end{array}$ & 8 Bdas \\
\hline $5 r-90$ & 0.0993 & $0.0998(1)$ & +0.5 \\
\hline $\mathrm{TC}-99$ & 1.039 & $1.306(45)$ & +25.7 \\
\hline $\mathrm{Cs}-137$ & 0.1916 & $0.164(3)$ & -14.4 \\
\hline$N p-231$ & 0.0100 & $0.0097(1)$ & -3.0 \\
\hline Total Pu & 0.143 & $0.148(39)$ & +3.5 \\
\hline$A m-243$ & 0.1489 & $0.13(2)$ & -12.7 \\
\hline
\end{tabular}

a The reference value is that determined by the sample's preparer, the MCC.

b Average of three determinations. Value in parentheses represents one standard deviation, for the final digits (1.e., 0.148 (39) represents an average value of $0.1 .48 \mu \mathrm{Cl} / \mathrm{mL}$, with a standard deviation of $\left.0.039 \mu \mathrm{C}_{1} / \mathrm{mL}_{1}\right)$. 
$W S R C-S W A-6$

Part 3

L.tem 400

Page 1.3 of 1.4

Date: 8191

Revision 1 B

EIGURE 3.400.1 Strategy to Determine Radlonuclide tnventory of DWPE Glass during Production.

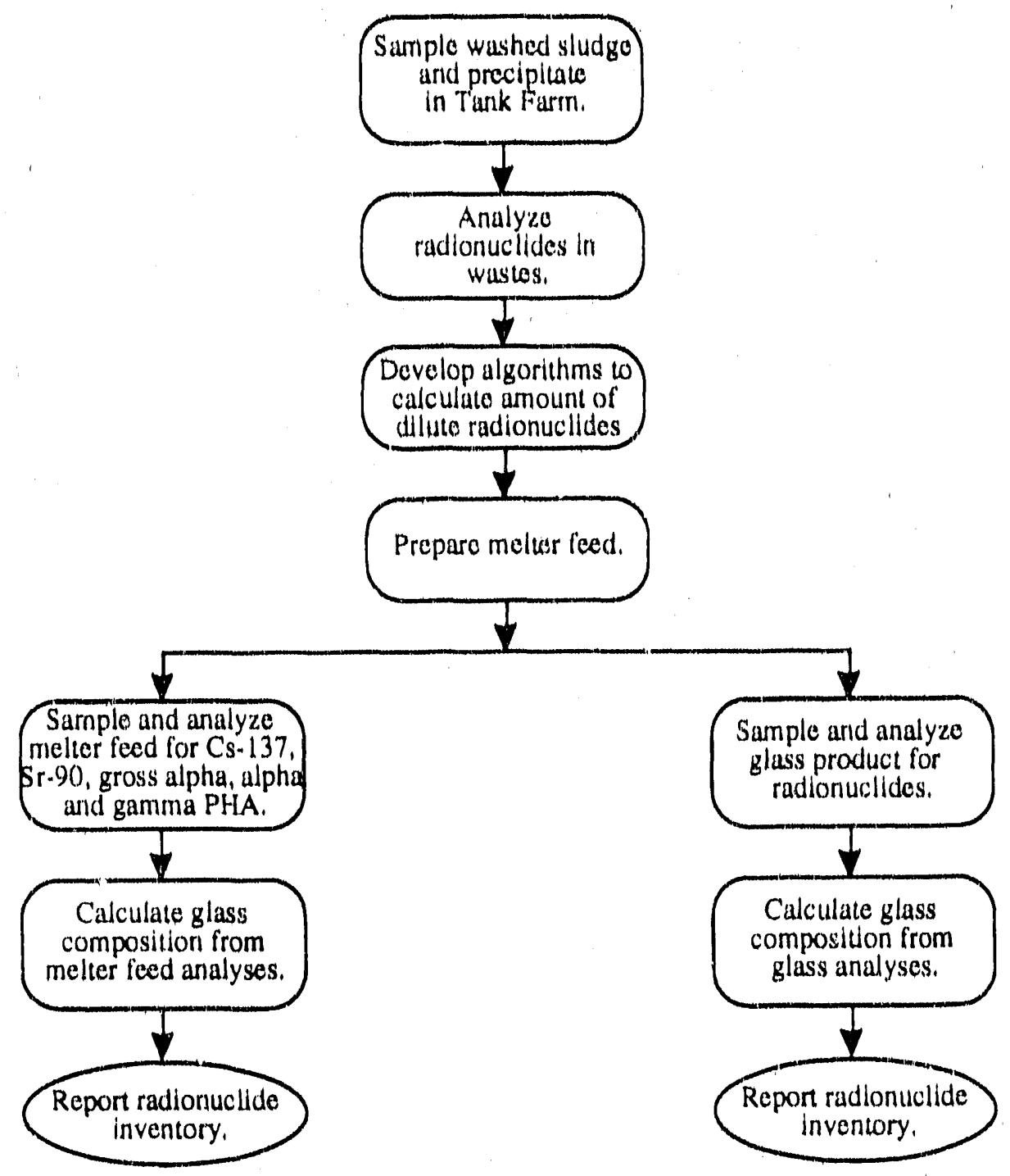




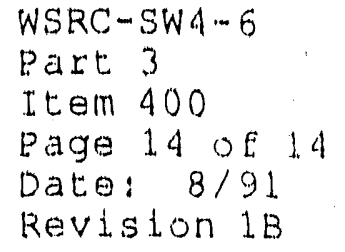

E'TGURE 3.400.2 Tasks planned to satigfy Speciflcation 1.2.2, Radionuclide Inventory during production.

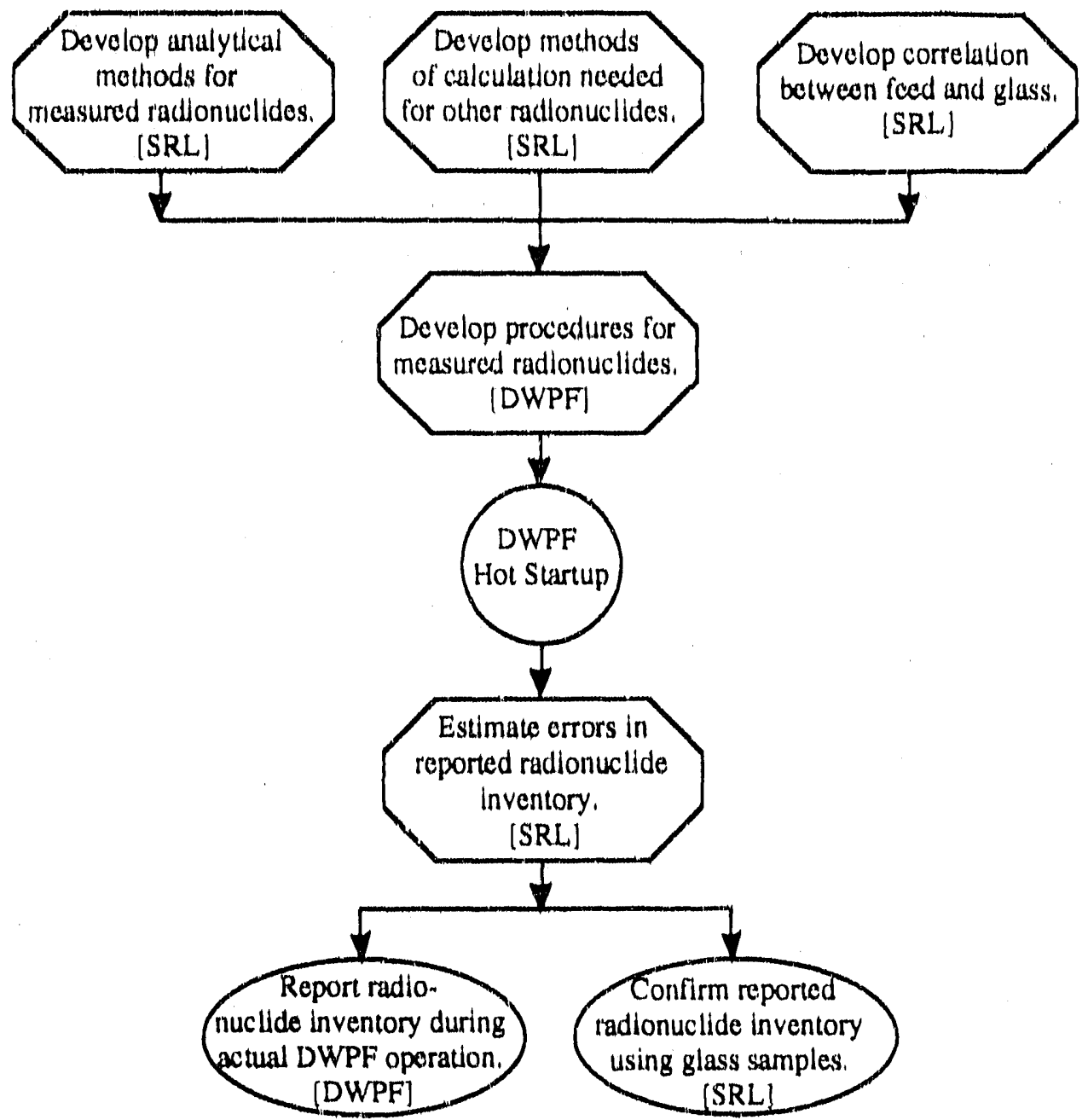




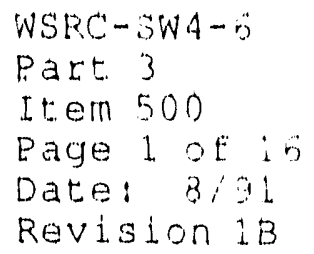

EART TITLE: NASTE E'ORM SPECIETCATIONS

ITEM TITLE: 1.3 SEECIEICATION EOR PRODUCT CONSISTENCY

\subsection{SPECIFICATION FOR RRODUCT CONSISTENCY}

The producer shall demonstrate control of waste form production by comparing production samples to the Environmental Assegsment (EA) benohmark glass to satisfy the oriterion of specification 1.3.1. The producer shall describe the method for demonstrating compliance in the WCP and shall provide verification in the production Records. The producer shall demonstrate the ability to comply with the spacification in the WQR.

\subsubsection{Acoentance Criterion}

The consistency of the waste form shall be demonstrated using the Product Consistency Test (PCT). For acoeptance, the concentra-tions of lithium, sodium and boron in the leachate, after normalizing for the concentrations in the glass, shall be less than those of the benchmark glass whose composition and release properties are described in the Environmental Assessment for selection of the DWP waste form. The reported mean PCT results for ilthiunn, sodium, and boron for the glass produced from each waste type shall be at least two standard deviations below the mean PCT re-. sults of the EA giass.

\subsubsection{Mathod of Complianaa}

The capability of the waste form to meet this specification shall be demonstrated by a combination of testing of production glass samplos and process control information. Glass samples shall be taken from the glass pour stream during canister filling or from a convenient location near the mouth of the waste form canister before the canister is sealed.

Production Records shall include results from testing actual samples, as well as any process control information to be used for verification. When using process control information to project PCT results, the producer shall demonstrate in the WQR that the method used will provide information equivalent to the testing of samples of actual production glass.

\section{Bationale}

The primary justification for this specification is the noed to 
WSRC-SN4-6

Part 3

Item 500

Page 2 of 15

Date: $8 / 9$ 1

Revision $1 \mathrm{~B}$

EART TITLE: WASTE FORM SPECIEICATIONS

ITEM TITLE: 1.3 SPECIFICATION FOR PRODUCT CONSISTENCY

ensure a consistent glass product by the control of the vitrification process.

This specification formally establishes the Environmental Assessment for the selection of the DWPF waste form [4] as a binding com mitment on the waste form producers. The specification requires that the PCT response for the glass waste forms shall be consi,s-" tently better than the glass described in the Environmental Assessment, which itself is an acceptable glass. The two-sigma limit provides a degree of conservatimn.

Specification 1.3 .1 uses the Produat Consistency Test (PCT) as the basis for this specification. The PET is considered to be a generally acceptable method of establishing product consistency and can be performed remotely in a hot-cell environment. The three elements to be analyzed (lithium, sodium and boron) for the PCT are sufficient, because they release faster than all other elements for all conceivable types of borosilicate HLW glass.

\section{compliancestrategy}

The only variable which can be controlled by the DWPF and which affects the results of the product consistency Test (PCT) is the chemical composition of the glass (For purposes of this discussion, the $\mathrm{Ee}$ (II)/Fe(Total) ratio is considered part of the chemical composition). For each waste type (macro-batch), the DWPF will satisfy the specification by ensuring that each process batch from that waste type will produce acceptable glass product. This will require demonstrating that an acceptable glass can be producec from that waste type, identifying a target composition for that waste type, controlling the composition of the melter feed, and then confirming control through periodic sampling.

The chemical composition of the glass will be controlled by ensuring that each batch of feed in the last feed preparation vessel, the Slurry Mix Evaporator (SME), will make acceptable glass, before the feed is sent to the Melter Feed Tank and the melter. The Product Composition Control system (PCCS) will be used to determine the acceptability of glass which will be produced from a given feed composition. An algoritinm will be developed which relates the composition of the giass to the results of the PCT. This composition algorithm will be included in the PCCS. The PCCS will 
WSRC-SNC-5

Part 3

It $y=500$

Page 3 of 15

Dare: $8 / 91$

Revision iB

PART TITLE: WASTE EORM SEECIEICATIONS

ITEM TITLE: 1.3 SPECIEICATION EOR PRODUCT CONSISTENCY

also take into account the uniformity of material in process vessels, errors in the sampling and measurement systems, and errors in the correlation between feed composition and leach test results. Only feed which will produce acceptable glass will be delivered to the melter. The melter has been designed so that feed material must reach temperatures sufficient to ensure an acceptable product in order to be poured into the canister.

The DWPE will then develop a glass product control program (GPCP) for control of the chemical composition of the glass during production. The WQR will contain the technical bases for the GPCP, the GPCP itself, as well as documentation demonstrating how well the chemical composition can be controlled, based on data from pilot plant testing, tests with actual waste, and, most importantiy, the Startup Test Program.

\section{Implementation}

The tasks planned to satisfy this specification are outlined in Eigure 3.500.1. They are

- Identification of the variables to be controlled. As will be discussed below, the chemical composition of the glass is the only variable which the DWPE can control which will affect the results of the PCT.

- Development of an algorithm relating the chemical composition of the feed to the results of the PCT. This task includes determination of the error associated with the algorithm.

- Demonstration that each of the projected compositions in Part

3, Item 100, is acceptabie.

- Demonstrations that the algorithm relating chemical composition and BCT results is an effective method of ensuring an acceptable product is produced.

- Characterization of the uniformity of material in process vessels (primarily the Slurry Mix Evaporator), and the errors associated with the DWPE's sampling and analytical measurement systems. This task 10 discussed in Part 3. Ttem 200. 
WSRC-SWA-5

Part 3

Item 500

Page 4 of 15

Date: $8 / 91$

Revision 13

PART TITLE: WASTE, EORM SPECIEICATIONS

ITEM TITLE: 1.3 SPECIEICATION EOR PRODUCT CONSISTENCY

- Development of the Product Composition Control system for use in the DWEE.

- Development of a glass sampler suitable for routine use in the DWPE.

- Development of a Glass Product Control Program, for control of the chemical composition of the glass during production.

- Testing of the PCCS, the glass sampler, and demonstration of the use of the GPCP during the qualification Runs portion of the Startup Test Program.

Identifivation of Impertant Variables

The properties affecting the performance of DWPE waste glasses on various leach tests have been extensively investigated over the last 15 years.1-7 As part of this scrutiny, two in-depth studies of the mechanisms of reactions between waste glasses and aqueous solutions have been performed.1,2

Under the leadership of the Materials Characterization Center (MCC), the Leaching Mechanisms Program investigated the mechanisms by which repository groundwater and DWPF glass interact. This study, which involved university, industrial and DOE laboratories, concluded that the reaction mechanisms depend on the composition of the glass, the repository's environmental conditions (groundwater composition, $\mathrm{pH}$ and Eh, temperature, flow rate of water and amount of water), and the time of contact between glass and leachant. 1

As part of its program to gain acceptance of DWPE glass, Savannah River Laboratory has also carried out extensive investigations ${ }^{2-7}$ of the mechanisms of reactions between glass and aqueous solutions. The first of these, which summarized the technical basis for the selection of borosilicate glass as the waste form for the DWPE, concluded that the performance of glass was governed by exactly the same factors identified in the MCC study.2 subsequent studies, $3-7$ have shown that the reactivity of glasses typical of those which will be produced in the DWPE are affected very little 


\author{
WSRC-SW4- 5 \\ Part 3 \\ Item 500 \\ Page 5 of 15 \\ Date: 8,191 \\ Revision $1 B$
}

\title{
PART TITLE: WASTE EORM SPECIEICATIONS
}

\section{ITEM TITLE: 1.3 SEECIEICATION EOR PRODUCT CONSISTENCY}

by variations in parameters such as residence time, 3 the size of the melter, ${ }^{4}$ or crystalline content of the glass. ${ }^{25-7}$ It has also been shown that DWPE-type glasses do not adversely affect either the Eh or the $\mathrm{pH}$ of groundwaters representative of candidate repository environments.8-12 Thus, the reactivity of the DWPE product toward aqueous solutions can best be controlled by controlling the chemical composition of the glass (as long as glass is made).

This position can also be fustified on a theoretical basis. The hydration thermodynamic approach, 13-5 originally developed to explain differences in durability of ancient glasses, leads to the prediction that the performance of glass should depend most

strongly on the chemical composition of the glass, and very little on other process parameters. In Eigure 3.500.2, the free energy of hydration calculated from the glass composition is plotted against the extent of reaction between glass and water, represented by the silicon release in a 28-day MCC-1 leach test (Development of similar plots for release of Li, Na, and $B$ in the PCT is currently in progress). As can be seen from the flgure, the reactivity of the glass toward water is strongly dependent on the glass compositjon. These glasses represent a wide range of synthetic and natural silicate glass systems, produced under both controlled and uncontrolled conditions. Similar plots have been generated from the results of in-situ testing. ${ }^{4}$

The DWPE has chosen to control glass composition through control of the composition of the feed in the last feed preparation vessel, the Slurry Mix Evaporator (SME). 16 Direct control of the glass composition is not possible because of the continuous nature of the DWPE process, and the virtual impossibility of collecting and recycling unacceptable glass. Consequently, the glass zomposition must be controlled through control of the feed composition. The SME has been selected as the control point because it is the last process vessel. through which direct chemical additions are routinely made. Thus, it can be used to adjust feed batches which might otherwise make unacceptable product. Because no further chemical additions are routinely made cownstream, the controls applied to material in the SME are highly unlikely to be overridden by actions downstream. 
WSRC - SW $4-6$

Eart 3

Itern 500

Page 6 of 16

Date: $8 / 31$

Revision 18

PART TITLE: WASTE EORM SPECIEICATIONS

ITEM TITLE: 1.3 SPECIEICATION EOR PRODUCT CONSISTENCY

\section{Algorithm Relating chemical compesition and PCT Besults}

Figure 3.500 .2 shows a strong correlation betwen the composition of the glass (as reflected in the free energy of hydration), and the results of the MCC-1 leach test. A similar relationship shall be developed between the glass composition and the results of the $\mathrm{PCT}$, in the following manner.

1) A set of glasses will be prepared which more than span the range of expected DWPE compositions, and which represent a variety of waste types. This set of compositions will be selected to defensibly develop an algorithm relating the chemical composition of the glass and the PCT results.

2) DWPE analytical methods will be used to characterize each glass.

3) The PCT protocol will be strictly followed, and each of the species specified in the WAPS monitored.

4) The error in the algorithm relating the chemical composition and the PCT results will be determined.

It is anticipated that the free energy of hydration approach will be used to relate the composition to the PCT results, since this approach has been successfully used on a wide varlety of test conditions and glass compositions. 17 However, other possible approaches will be tested, including purely empirical ones.

\section{Demenstrations of the control of semposition}

SRL will demonstrate the effectiveness of the composition/PCT algorithm in both engineering-scale tests with simulated waste, and small-scale tests with actual waste. For both sets of tests, the algorithm will be used to formulate glasses which should be acceptable, even including errors based on melter feed non-uniformity, sampling, and analyses. Processing of the feed, including feed preparation, feed adjustment, and vitrification, will then be performed in a manner representative of the DrNPE process. The glass product will then be characterized using the PCT. The projected performance will then be compared to the actual performance 
$W S R C-3 W 4-6$

part 3

Item 500

Page 7 of 16

Date: $8: 91$

PART TITLE: WAG ERM SPECIEICATIONS

Revision $1 B$

ITEM TITLE: 1.3 SEECTEICATION FOR PRODUCT CONSISTENC'

of the glass to determine the effectiveness of the selcoted algorithm in producing an acceptable product.

\section{Qualification of Glass compesitions}

Each of the projected glass compositions (see part 3, Item 100) has been formulated to produce an acceptable glass product. They will be subjected to the PCT, to establish their acceptability. In addition, for each waste type, a variability study will be performed, which establishes the applicability of the relationship between the PCT results and the chemical composition for that waste type. If the relationship does not apply over the entire range of compositions, then the DWPE will either constrain the process to operate only within the region over which the relationship does apply, or will develop a new relationship for that waste type.

Before a macro-batch of waste is processed in the DWPE, the composition of the glass expected to be produced (target blend - see below) will be specified so that it will satisfy the specification. The algorithm relating composition and the PCT results will be used to do this, as described below. Eor future waste compositions, samples will be prepared and tested with the PCT to ensure that the behavior expected based on the PCCS prediction is realized in practice. Thus, each of the projected compositions will be subjected to the PCT and shown to produce glass capable of meeting the specifications before production begins.

\section{Preduct compesition centrol sustem (PCCSL}

The composition/PCT algorithm will be embedded in a software system, the PCCS, which will also take into account the uncertainties associated with feed uniformity, the sampling system, the analytical system, and the composition/PCT algorith itself. This system will ensure that the feed will be processable in the melter, and that it will produce glass which satisfies the specification.

The heart of the PCCS will be the statistical process control (SPC) algorithm, which will use each of the pieces of information listed above to:

- Derive target blends of frit, sludge and PHA (see Part 1, Item 
WSRC-SW4-6

Part 3

Item 500

Page 3 of 15

Date: $8 / 91$

Revision 13

PART TITLE: WASTE EORM SPECIEICATIONS

ITEM TITLE: 1.3 SPECIEICATION EOR PRODUCT CONSISTENCY

300 for definitions of these terms) for each macro-batch.

- Monitor each process batch in the SME (through use of chemical analyses), to determine its acceptability (ability to produce glass whose mean PCT results are at least two standard deviations better than the mean PCT results of the benchmark glass).

- Derive a remediation strategy for any process batches which are not yet within operating limits.

The SPC algorithm will necessarily be multi-variate in nature, and will use Hotelling's $\mathrm{T}^{2}$ as the control statistic for the process batch.18 The SPC algorithm will also use mass-balance information from operation of the process to improve its estimates of the actual composition of the process batch in the SME. A Kalman filter state model will be utilized to do this. 19

The PCCS will be tested during the Qualification Runs portion of the startup Tesit Program. The predicted performance of the glass on the PCT will be compared to the PCT results from glass samples taken during pouring, and from samples of the glass taken from each canister. The Qualification Runs are discussed more fully in Appendix 1.200.3.

\section{Glass Sampling}

Confirmatory glass samples will be taken from the pouring glass stream periodically during actual DWPE production. When glass samples are taken in the DWPE, they will be sent to SRL for chemical and radiochemical analyses. At least one glass sample will be taken from each macro-batch ( 1 every 3 to 4 months) to confirm that the glass produced satisfies the specification. Initially, however, more will be taken.

A g?.ass sampler suitable for routine DWPE use has been developed and tested. Approximately $50 \mathrm{~g}$ of glass will be taken from the flowing stream of molten glass as it is poured from the melter into the canister. A prototype unit is shown in Eigure 3.500.3. During the Qualification Runs (see Appendix 1.200.3), glass samples taken with the reference sampler from the pouring glass streams will be compared to samples taken from the canisters di- 
WSRC - SWA -6

Part 3

Item 500

Page 9 of 15

Date: $8 / 91$

Revision lB

\section{PART TITLE: WASTE EORM SPECIEICATIONS}

\section{ITEM TITLE: 1.3 SPECIEICATION EOR RRODUCT CONSISTENCY}

rectly. Both the chemical composition and the performance of the glass on the PCT will be compared. This test is intended to establish that the glass sample is representative of the contents of the canister.

During production, the chemical composition uf each production glass sample will be determined, and the projected PCT results calculated. A portion of each production glass sample will be tested with the PCT. This will provide additional assurance that the process has been controlled so that the PCT results of actual. DWPE glasses are consistent with those reported in the waste Form Qualification Report.

\section{Glass Product control Program}

The elements of the glass product control program for glass chemical composition include specification of a target composition and SME sampling regimen (number of samples, number of analyses per sample), Slurry Mix Evaporator (SME) sampling and sample analyses, determination of feed acceptability, adjustment if necessary, and confirmation through glass sampling.

Establishment of target compositien. For each macro-batch of material, the DWPE will establish a target feed composition which will produce an acceptable glass, using the PCCS. At the same time, a sampling regimen will be specified for each batch so that the DWPE production staff can be assured that the statistical confidence limit in the WAPS will be met for each process batch before it is allowed to pass forward to the Melter Feed Tank (MFT'). Thus, this specification of the sampling regimen will include consideration of the errors of sampling and analyses, as well as the composition/PCT algorithm. As noted in Part 3, Item 200, the errors of sampling and analyses will be quantified during the startup Test Program. It is likely that the sampling regimen specified for the initial macro-batch will also be adequate for subsequent ones.

SME sampling and analyses. Samples of each batch of feed from the SME will be taken using the sampling system shown in Eigures 3.200 .3 and 3.200 .4 . The number of samples will be determined during the Qualification Runs, based on the number of measurements necessary to satisfy the specification. The analytical techniques 
WSRC-SW4-6

Part 3

Item 500

Page 10 of 1.6

Date: $8 / 91$

Revision $1 B$

PART TITLE: WASTE EORM SPECIFICATIONS

ITEM TITLE: 1.3 SPECIEICATION EOR PRODUCT CONSISTENCY

w111 be the same as those discussed in Part 3, Item 200. The precision and accuracy of sampling and measurement will be determined as part of the startup test program.

Determination of acceutablilty. For each batch of feed, the chemical composition measured on a vitrified sample of feed will be used as input to the PCCS. If the PCCS predicts that the process batch would produce an unacceptable product, the feed matertal will be held in the SME, and its composition adjusted and reanalyzed. If the PCCS predicts that the materlal will produce glass which complies with the specification, the process batch will be transferred to the Melter Eeed Tank, and then to the melter.

Eeed adjustment. If the PCCS predicts that the process batch would produce an unacceptable product, additional sampling and analyses is likely to be the first course of action. The additional analyses will be used in conjunction with the original analyses to determine the acceptability of the feed. However, if the results still indicate that the process batch is unacceptable, then, in general, addition of frit will be all that is necessary for adfustment. The amount of frit will be specified by the PCCS. The SME is also eyilpped with cold feed lines which will allow additional flexibility if chemical additions (e.g., borlc acid) are necessary. The SME material will be re-sampled and analyzed again after adjustment to confirm that it has been successfully remediated. Transfer of material to the Melter Feed Tank will only be allowed when it has been determined that the SME material will produce glass which satisfies the specification.

During the Qualification Runs, the GPCP will be used in production. The results of these runs will be reported in the waste Form Qualification Report (WQR). The Glass Product Control Program itself will also be described in the WQR. This part of the WQR Will

(1) Provide a description of the product, process, and processing equipment;

(2) Identify the requirements for the product (primarily based on this specification);

(3) Identify the process variables which affect the ability of 
WSRC $-5 W 4-6$

Part 3

Item 500

Page 11 of 1.6

Date: $8 / 91$

Reviston $1 B$

PART TITLE: WASTE EORM SPECIEICATIONS

ITEM TITLE: 1.3 SPECIEICATION EOR PRODUCT CONSISTENCY

the product to meet the requidrements (chemical composition of the Eeed);

(4) Identify those actions which will be taken to control the chemical composition, and to verlfy that tt has been controlled;

(5) Describe the method of reporting those actions.

Documentation

The Waste Form Qualification Report will detail the development of the algorithm relating the chemical composition of the glass to the PCT results. The Product Composition Control system will be described in detall, as well as the testing of the PCCS which will be performed during the Qualification Runs. The results of the effort to demonstrate the acceptablitity of each of the projected glass compositions will also be included in the WQR.

The Glass Product Control Program will also be documented in the WQR. The accuracy and precision of the methods of control will also be reported. The WQR will also report on the use of the glass sampler, and the comparison of the samples taken from the pouring stream with samples taken from the canister 1tself.

The Production Record for each canistered waste form will contain the chemical composition of the glass (see Part 3, Item 200), and the predicted results on the PCT. The results of analysis and testing of glass samples from each macro-batch will also be included in the production Records.

\section{Beferences}

1. J. E. Mendel (ed.), rinal Report of the Defense High-Lavel Waste Leaching Mechanisms Program, USDOE Report PNL-5157, Battelle-Pacific Northwest Laboratory, Richland, WA (1984).

2. M. J. Plodinec, G. G. Wicks, and N. E. Blbler, An Assassment of Savannah River Borosilicate Glass in the Repository Environment, USDOE Report DP-1629, Savannah River Laboratory, Aiken, SC (1982).

3. D. E. Blckford, P. Hrma, B. W. Bowan, III, "Control of Radio- 
PART TILE: WASTE FORM SPECIEICATIONS

ITEM TITLE: 1.3 SPECIEICATION EOR PRODUCT CONSISTENCY

active Waste Glass Melters: II, Residence Time and Melt Rate LimLtations," J. Am. Car. Soc., 73, 2903-15 (1990).

4. M. J. Plodinec, "Characterlzation of Savannah River Plant. Waste Glass," Waste Management 85, 1, R. G. Post (ed.), 441-5 (1985).

5. C. M. Jantzen, D. E. Blckford, D. G. Karraker and G. G. Wicks, "Time-temperature-transformation kinetics in SRL glass," Advances in Ceramics - Nucleax Waste Management, 8, W. A. Ross and G. G. Wicks (eds.), 30-38 (1984).

6. D. E. Bickford and C. M. Jantzen, "Devitriflcation Behavior of SRL Defense Waste Glass," Scientific Basis for Nuclear Waste Management, VII, G. L. MCVay (ed.), Elsevier, NY, 557-66, (1984).

7. C. M. Jantzen and D. E. Blckford, "Leaching of Devitrified Glass Containing Simulated SRP Nuclear Waste," Scientific Basis for Nuclen Waste Management, VIII, C. M. Jantzen, et al. (ed), Materials Research Society, Pittsburgh, PA, 135-46 (1985).

8. N. E. Bibler and C. M. Jantzen, "Materials Interactions Relating to Long-T'erm Geologic Disposal of Nuclear Waste Glass," Scientific Basis for Nuclear waste Management, $X, J . K$. Bates (ed), 47$66(1987)$.

9. C. M. Jantzen and N. E. Bibler, "The Role of Groundwater Oxidation potential and Radiolysis on waste Glass performance in Crystalline Repository Environments, "Scientific Basis for Nuclear Waste Management, IX, L.O. Werme (ed.), Materials Research Society, Pittsburgh, PA 219-229 (1986).

10. N. E. Blbler, "Leaching Fully Radioactive SRP Nuclear Waste Glass in Tuff Ground-Water in Stainless Steel Vessels, "Advances in Ceramics - Nuclear Waste Management, 20, D. E. Clark, et al. (ed), 619-626 (1986).

11. N. E. Bibler, G. G. Wicks and V. O. Oversby, "Leaching of SRP Nuclear Waste Glass in a Saturated Tuff Environment," Sciontific

Basis for Nucleax Waste Management, VIII, C. M. Jantzen, J. A. Stone and R. C. Ewling (eds.), 247-56 (1985). 
WSRC- $3 W 4-5$

Part 3

Item 500

Page 13 D 130

Date: $8 / 91$

Revision 18

EART TITLE: WASTE EORM SPECIEICATIONS

ITEM TITLE: 1.3 SPECIEICATION FOF RODUCT CONSISTENCY

12. G. G. Wlcks, "Nuclear Waste vitriflcation - The Geology Connection," J. Non-Cryst. Solids, 84, 241-50 (1986).

13. M. J. Plodinec, C. M. Jantzen, G. G. Wlcks, "Thermodynamic approach to prediction of the stablilty of proposed radwaste glasses," Mdvances in Ceranios - Nuclear Waste Management, 8, W. A. Ross and G. G. Wicks (eds.), 491-95 (1984).

1.4. C. M. Jantzen and M. J. Plodinec, "Thermodynamic Model of Natural, Medieval and Nuclear Waste Glass Durability," J. Non-Cryst. Solids, 67, 207-23 (1984).

15. M. J. Plodinec, C. M. Jantzen and G. G. Wlcks, "stability of Radioactive Waste Glasses Assessed from Hydration Thermodynamics," Scientific Basis for Nuclear Waste Management, VII, G. L. MCVay (ed.), 755-62 (1985).

16. J. T. Carter, K. G. Brown, and D. E. Blckford, "DWPE Glass Composttion Control Based on Glass Propertles, "Proceedings -

First International Conference on Advances in the Fusion of Glass, D. E. Blckford, et al. (ed.), Amerlcan Ceramic Soclety, Westerville, OH, chapter 20 (1988).

17. C. M. Jantzen, "Prediction of Glass Durability as a Eunction of Glass Composition and Test Conditions: Thermodynamics and Kinetics," Proceedings - First International Conference on Advances in the Fusion of Glass, D. E. Blckford, et al. (ed.), American Ceramic Society, Westervilie, OH, chapter 24 (1988).

18. H. Hoteling, "The Generalization of Student's Rat1o," Annals of Mathematical Statistics, 2, 360-78 (1931).

19. R. E. Kalman, "A new approach to linear flltering and prediction problems," Trans. ASME J. Basic Ing,, 82D, 34-45 (1960). 


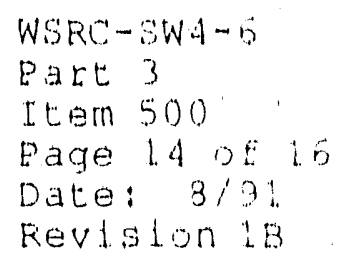

EIGURE 3.500.1 Tasks planned to satisfy specification 1.3, Specification for Product conststency.

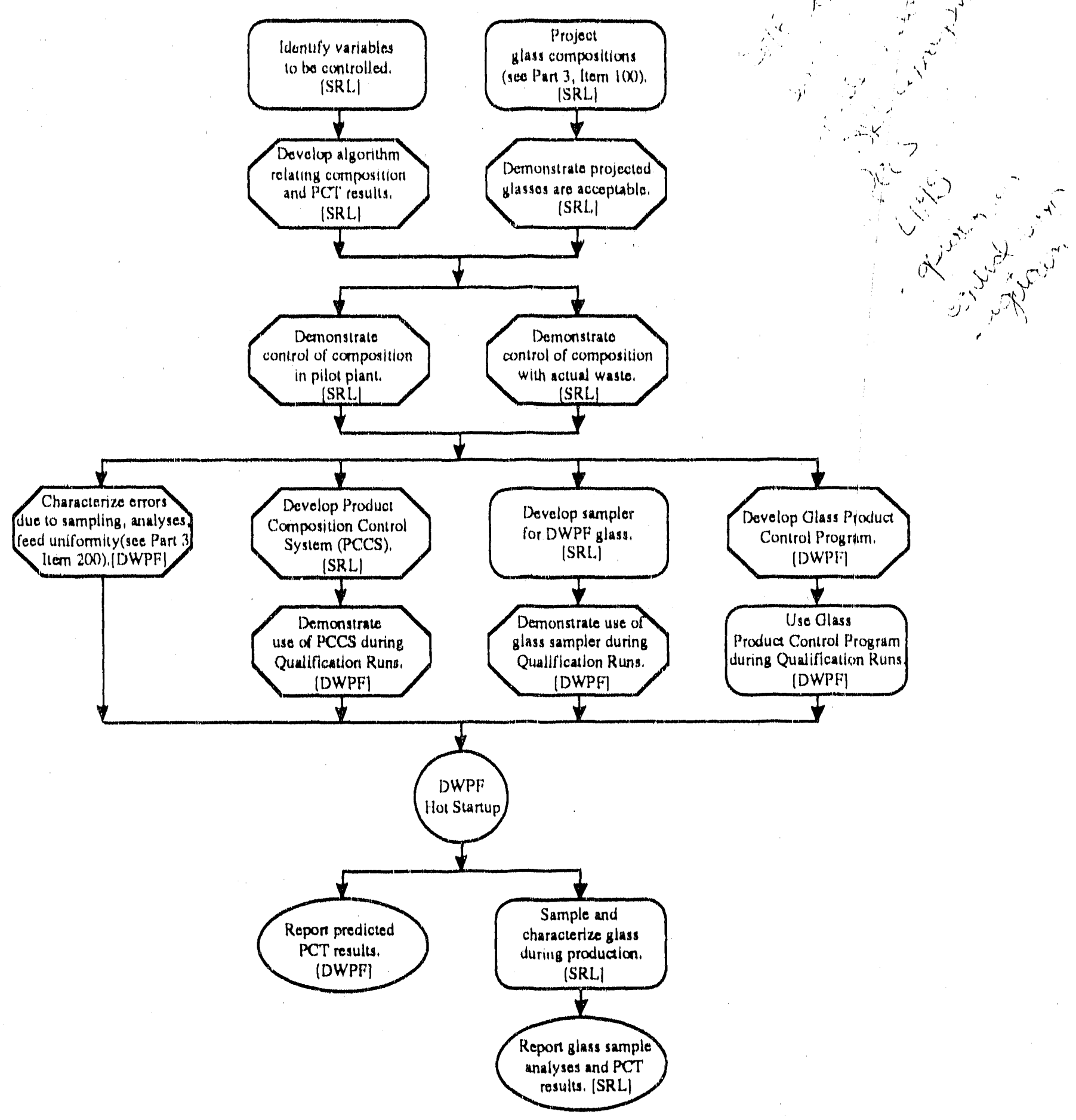


$W S R C-S W 4-6$

Part 3

It them 500

Page 15 of :5

D c te: $8: 9:$

Reviston 13

EIGURE 3.500.2 Effect of glass composttion on reactivity of glass with water.

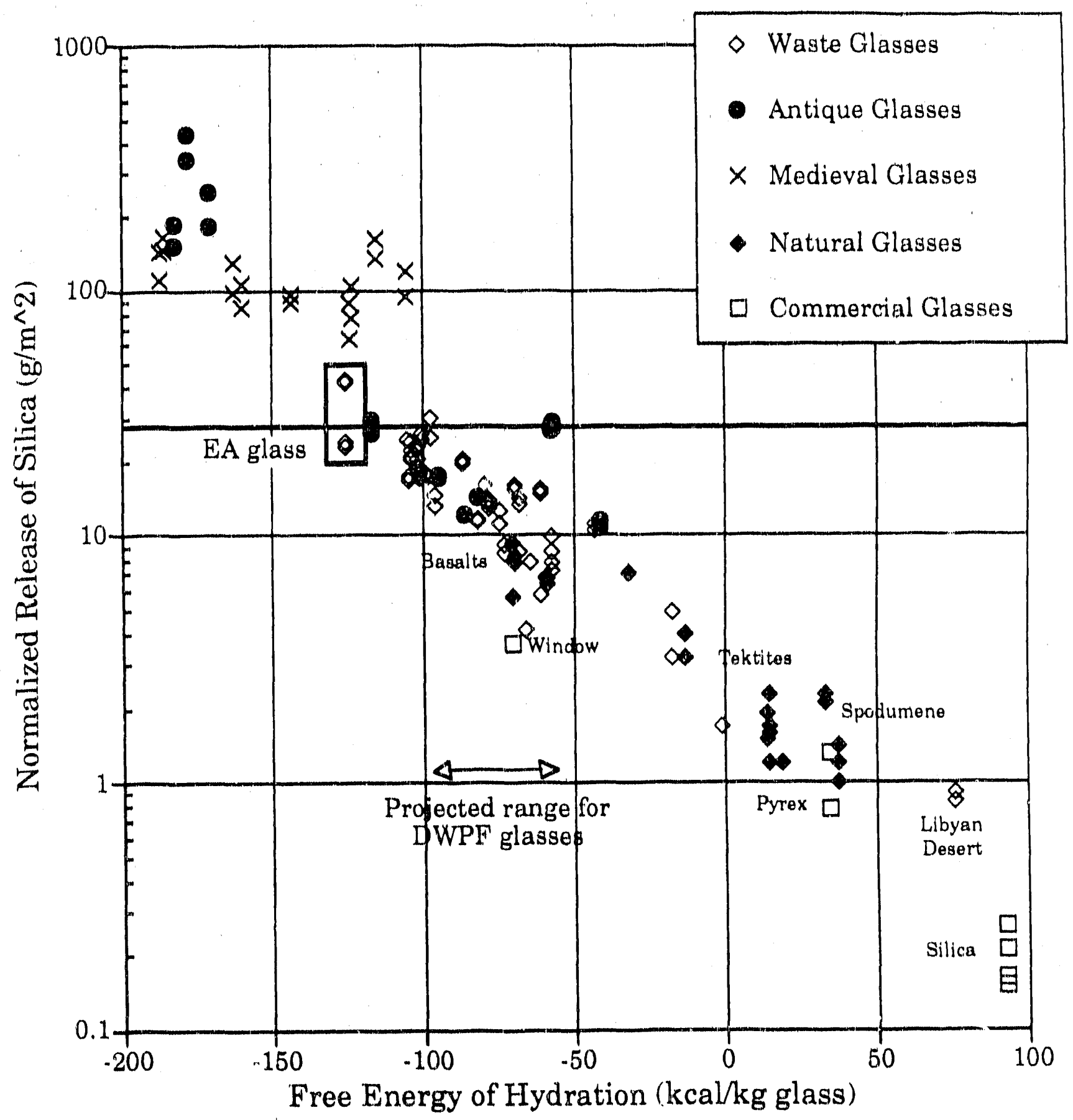

MCC-1 test results - glass exposed to delonized water for 28 days, at $90^{\circ} \mathrm{C}$. 
WSRC-SW4-6

Part 3

Item 500

Page 16 of 16

Date: $8 / 91$

Revision $1 \mathrm{~B}$

EIGURE 3.500 .3 DWPE glass sampler.

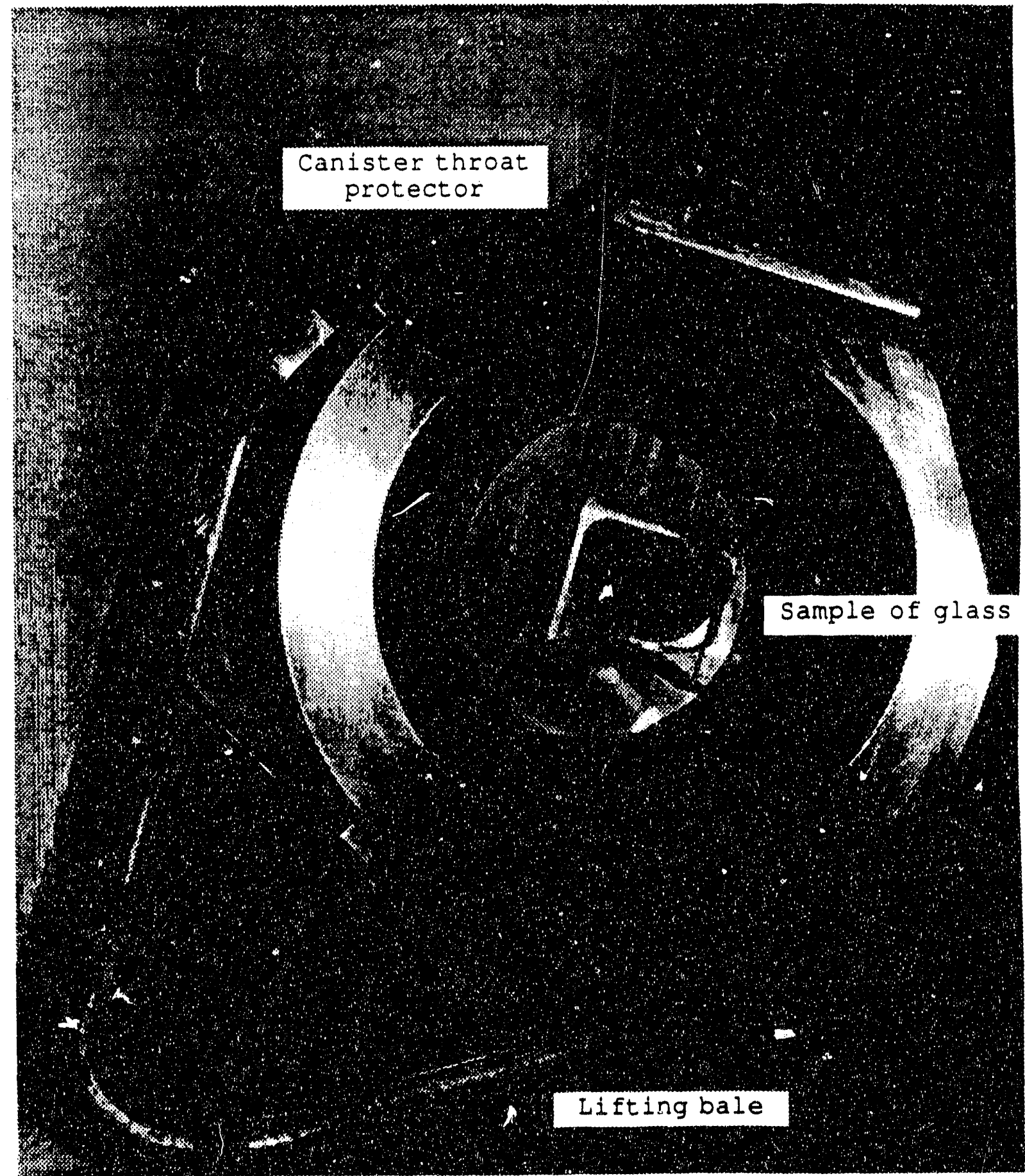


PART TITLE: WASTE FORM SPECIEICATIONS

ITEM TITLE: 1.4 SPECIEICATION EOR PHASE STABILITY

\subsection{SPECIFICATION FOR PHASE STABILITY}

\subsubsection{Phase Stability Information}

The producer shall provide the following data for each waste type:

(a) The glass transition temperature; and

(b) Time-temperature-transformation (TTS) diagrams that identify the duration of exposure at any temperature that causes significant changes in either the phase structure, the phase compositions, or the PCT response of the borosilicate glass waste type.

The method to be used to demonstrate compliance shall be described in the WCP. The data shall be provided in the WQR.

\subsubsection{Control of Temperature for Phase Stability}

At the time of shipment, the producer shall certify that after the initial cool-down, the maximum waste form temperature has always been at least $100^{\circ} \mathrm{C}$ below the glass transition temperature. The producer shall describe the method of compliance in the WCP.

\section{Rationale}

The specification will provide data useful to the repository project for establishment of ropository and waste package design temperature limits. The certifications required will provide assurance that the producer has not handled or stored the waste forms in such a way as to cause changes in the phase structure that could significantly affect glass properties.

The available evidence indicates that the borosilicate glass waste form will retain properties similar to those obtained under specification 1.3 so long as the phase structure and composition of the glass are unchanged from those provided under Specification 1.1. The evidence also indicates that neither energy input nor radioactive decay significantly affect releage from waste glass, as long as the temperature of tho glass does not exceed the glass transition temperature (approximately $500^{\circ} \mathrm{C}$ ). Above this temperature, significant changes in phase composition can occur. 
WSRC-SW $4-6$

Part 3

Item 600

Page 2 of 9

Date: $8 / 91$

Revision 18

PART TITLE: WASTE EORM SPECIEICATIONS

ITEM TITLE: 1.4 SPECIEICATION FOR PHASE STABILITY

\section{Compliance strategy}

The transition temperatures and time-temperature transformation (TTT) diagrams will be determined for the set of projected glass compositions developed as described in Eart 3, Item 100. Standard dilatometric methods (ASTM C336) will be used to determine transition temperatures. Time-temperature transformation (TTT) diagrams will be developed using methods previously employed by researchers at SRL.1-3 SRL will then perform the DWPE Product Consistency Test on the heat-treated glasses.

The heat generation rate of free-standing canistered waste forms is so low that no special actions are needed to meet the specification. During interim storage in the DWPE's Glass waste storage Building, the heat generation rate of DWPF canistered waste forms will not be great enough to exceed the specified temperature.

However, forced air cooling will be used which will further ensure that the canisters do not exceed the specified temperature.

\section{Implementation}

The tasks planned to satisfy this specification are outlined in Eigure 3.600.1. They are

- Projection of glass compositions. This task is described in Part 3, Item 100.

- Determination of glass transition temperatures for each of the projectedglasses.

- Documentation that the design of the DWPE's storage facility will maintain the maximum glass temperature at least $100^{\circ} \mathrm{C}$ below the glass transition temperature.

- Development of time-temperature transformation diagrams for the projected gla:ses, and performance of the PCT on the heat-treated glasses.

\section{Glass Transition Temperatures}

As the projected glass compositions in Part 3, Item 100, are de- 
WSRC $-S W 4-5$

Part 3

Item 500

Page 3 of 9

Date: $8 / 31$

Revision $1 \mathrm{~B}$

PART TITLE: WASTE EORM SPECIEICATIONS

ITEM TITLE: 1.4 SPECIEICATION EOR PHASE STABILITY

fined, the glass transition temperature, $\mathrm{Tg}$, of each of the projected glasses will be determined, using the ASTM C336 standard test method. An example of a dilatometric curve for Design-Basis DWPE glass is shown in Eigure 3.600.2. As can be seen in Table 3.600 .1 , the glass transition temperatures do not depend very strongly on composition. If, as is currently believed, the glasses listed in Table 3.600 .1 are representative of the range of,compositions of the DWPE canistered waste forms, then the transition temperatures of DWPF glasses will be in the range $440-460^{\circ} \mathrm{C}$.

\section{Resign ef Glass Waste Storage Building}

After filling, the temperatures of the canistered waste forms will not be routinely monitored in the DWPE. However, the canister surface temperature will be checked before it is inserted in the Canister Decontamination Chamber (CDC). The canister temperature must be below $100^{\circ} \mathrm{C}$, prior to canister decontamination, to prevent steam generation. This provides a convenient operational definition of the end of initial cooldown.

Calculations have been performed4,5 (using the HEATING5 finite element heat transfer code) which show that free-standing DWPF canistered waste forms will not exceed the specified temperature even at heat loadings $2-3$ times higher than expected for DWPE glass (see Table 3.600.2; the Design-Basis heat loading is $~ 690$ watts). Thus, it is not possible to exceed the specified temperature $\left(100^{\circ} \mathrm{C}\right.$ below $\left.\mathrm{Tg}\right)$ in the vitrification building after cooldown is completed because the canisters are essentially free-standing in ambient air.

The canisters will be transported from the vitrification building to an interim storage facility, called the Glass waste Storage Building (GWSB). Here, they can no longer be considered as freestanding objects in ambient air. However, the GWSB has been designed so that the maximum temperature of the canistered waste forms cannot exceed the specified temperature. Calculations to establish this will be provided in the WQR.

An analysis of the design of the initial GWSB will be performed to establish that the glass cannot reach or exceed the specified temperature. The lowest expected glass transition temperature is approximately $440^{\circ} \mathrm{C}$. Initial estimates of the temperature during 
WSRC - SW $4-6$

Part 3

Item 600

Page 4 of 9

Date: $8 / 91$

Revision 18

PART TITLE: WASTE EORM SPECIEICATIONS

ITEM TITLE: 1.4 SEECIEICATION FOR PHASE STABILITY

storage indicate that canister heat loads of greater than 3 kilowatts ( $>4 \times$ the maximum projected heat generation rate of DWPE canistered waste forms) would be necessiary to exceed $340^{\circ} \mathrm{C}$ during storage.

Time-Temperature Iransformation Diagrams and PCT Testing

Time-temperature transformation diagrams for each of the projected glasses will be developed. The effects of changes of phase composition on the results of the product Consistency Test (PCT) will be determined by testing all heat-treated samples.

TTT diagrams of glasses with specific frit and waste compositions have already been developed. In general, it has been found ${ }^{6,7}$ that the durability of DWPE glass depends more strongly on the glassformer (frit and PHA) composition, than on the sludge composition. Over the range of expected glass compositions and canister cooling conditions, these studies also indicate little effect of crystalline content on glass durability.

\section{Qualification of Euture Glass compositions}

When future waste compositions are identified, glasses will be formulated for them which will satisfy the criterion in part 3 , Item 500. These glasses will be subjected to the same testing (glass transition temperature, TTT determinations, PCT results) as is currently being done for projected compositions developed as described in part 3, Item 100. The res"lts of these studies will be submitted to the repository program is an addendum to the WQR.

The heat generation rate of future waste compositions will also be calculated from the projected radionuclide inventory. If the heat generation rate could cause the maximum glass cemperature to exceed the specified storage temperature, the WQR addendum will also detail those actions which will be taken to prevent this from happening.

\section{Decumentation}

The Waste Form Qualification Report will include the glass transitiun temperatures of the projected glasses. The WQR will also include time-temperature transformation diagrams for each of the 
WSRC-SWA- 5

Part 3

Item 600

Page 5 of 9

Date: $8 / 91$

Revision $1 \mathrm{~B}$

PART TITLE: WASTE EORM SPECIEICATIONS

ITEM TITLE: 1.4 SPECIEICATION EOR PHASE STABILITY

projected glasses, and PCT results for all heat-treated samples.

The Shipping and Storage Record for each canistered waste form will certify that the maximum waste glass temperature experienced during storage of each canistered waste form has been at least $100^{\circ} \mathrm{C}$ below the transition temperature. The shipping and storage Record for each canistered waste form will also certify that after initial cooldown, no unusual events occurred which would cause the maximum temperature of the canistered waste form to exceed the same temperature, during handling and storage at the DWPF.

\section{Beferences}

1. C. M. Jantzen, D. F. Bickford, D. G. Karraker and G. G. Wicks, "Time-temperature-transformation kinetics in SRL waste glass," Advances in Ceramics - Nuclear Waste Management, $8, W$. A. Ross and G. G. Wicks (eds.), 30-38 (1984).

2. D. F. Bickford and C. M. Jantzen, "Devitrification Behavior of SRL Defense Waste Glass," Scientific Basis for Nuclear Waste Management, VII, G. L. MCVay (ed.), Elsevier, NY, 557-66, (1984).

3. D. F. Bickford and C. M. Jantzen, "Devitrification of Defense Nuclear Waste Glasses: Role of Melt Insolubles," J. Non-Cryst. Solids, 84, 299-307 (1986).

4. R. G. Baxter, Description of Defense Waste Processing Facility Reference Waste Form and Canister, USDOE Report DP-1606, Revision 1, E. I. Dupont de Nemours and Co., Inc., Savannah River Plant, Aiken, SC 19808 (1983).

5. M. H. Tennant, "Temperatures Generated by Underground Storage of Defense Waste Canisters," Scientific Basis for Nuclear Waste Management, II, C. J. M. Northrup (ed.), 825-32 (1980).

6. C. M. Jantzen and D. E. Bickford, "Leaching of Devitrified Glass Containing Simulated SRP Nuclear Waste," Scientific Basis for Nuclear Waste Management, VIII, C. M. Jantzen, et al. (ed), Materials Research Society, Pittsburgh, PA, 135-46 (1985).

7. N. E. Bibler, "Characterization of borosilicate glass containing Savannah River Plant radioactive waste," Glastekn. Ber., 56K, $736-41$ (1983). 
WSRC-SW $4-6$

Part 3

Item 600

Page 6 of 9

Date: $8 / 91$

Revision 13

TABLE 3.600.1 Glass Transition Temperatures for SRL Simulated Waste Glasses.

Cempesition*

Glass Transition Temperature

Design-Basisglass

$459^{\circ} \mathrm{C}$

165 / Purex waste

$448^{\circ} \mathrm{C}$

$165 /$ HM waste

$451^{\circ} \mathrm{C}$

$131 /$ Design-Basis waste

$460^{\circ} \mathrm{C}$

* 131 and 165 refer to glass-former compositions used by SRL. Frit 165 is similar to current DWPE glassformer (frit combined with PHA) compositions. Frit 131 represents an extreme composition, high in alkali and boron. Purex and HM refer to two hypothetical waste compositions (see Part 3, Item 100). 
WSRC $-5 W 4-6$

Part 3

Item 600

Page 7 of 9

Date: $8 / 91$

Revision 13

TABLE 3.600.2 Temperatures of Eree-Standing Canisters.

\begin{tabular}{|c|c|c|c|}
\hline Watts & $\begin{array}{l}\text { Surface } \\
\text { Teme. }\left({ }^{\circ} \mathrm{C}\right)\end{array}$ & $\begin{array}{l}\text { Centerline } \\
\text { Temp. (o) }\end{array}$ & $\begin{array}{l}\text { Surrounding } \\
\text { Air Temp. }{ }^{\circ} \mathrm{Cl}\end{array}$ \\
\hline $425^{*}$ & 34 & 50 & 20 \\
\hline $510^{*}$ & 54 & 71 & 38 \\
\hline $690 * \star$ & 58 & 89 & 38 \\
\hline 1000 & 66 & 120 & 38 \\
\hline
\end{tabular}

* Earlier values used for design purposes.

* Design-basis DWPF canistered waste form. 


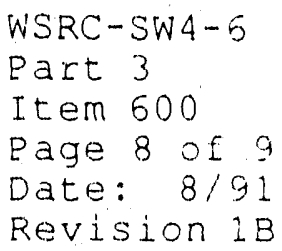

FIGURE 3.600.1 Tasks sufficient to satisfy specification 1.4, specification for phase stability.

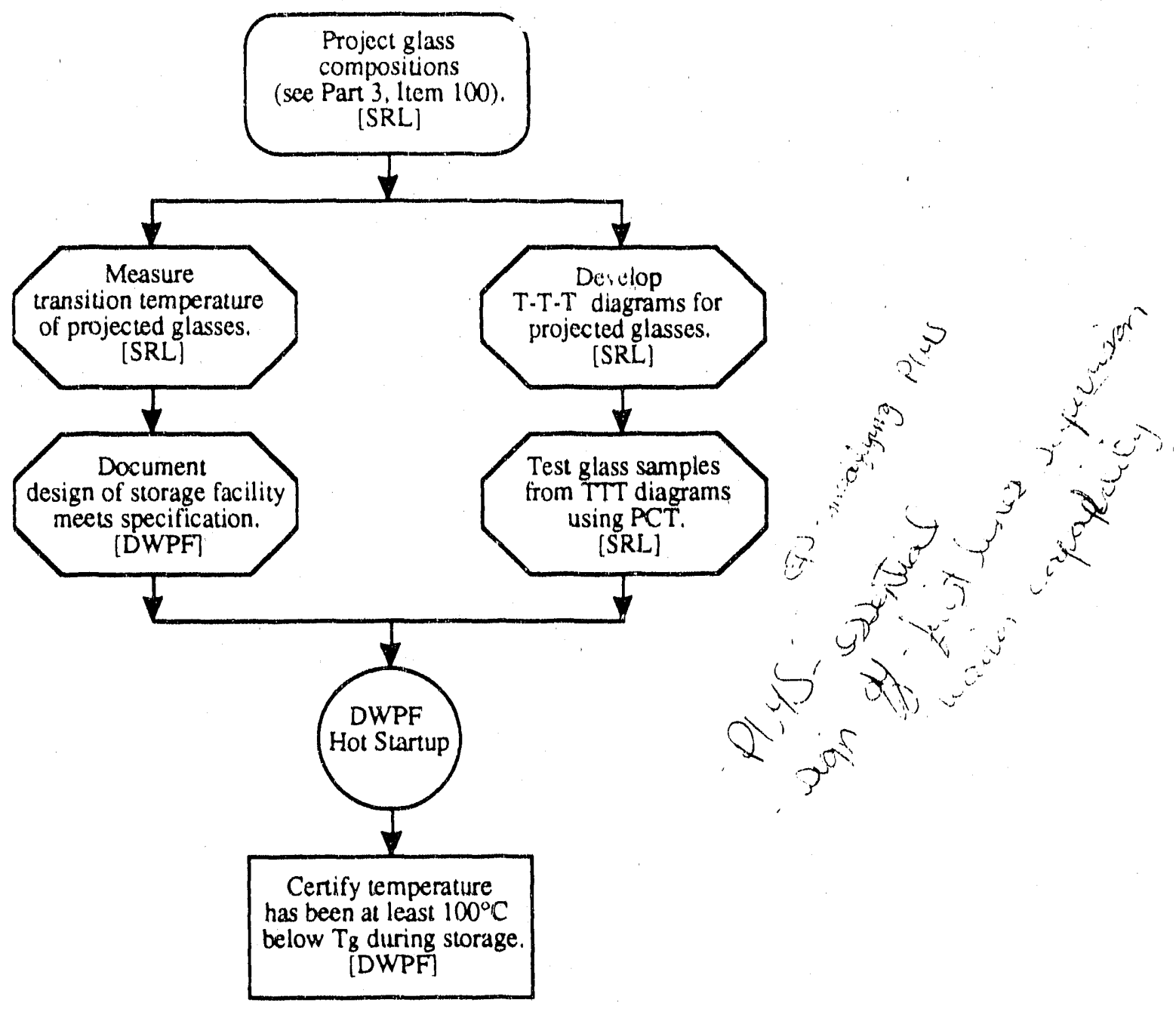


WSRC-SW 4- 6

Part 3

Item 600

Page 9 of 9

Date: $8 / 91$

Revision $1 \mathrm{~B}$

EIGURE 3.500.2 Dilatometric Determination of $\mathrm{T}_{\mathrm{g}}$ for Design-Basis DWPE glass.

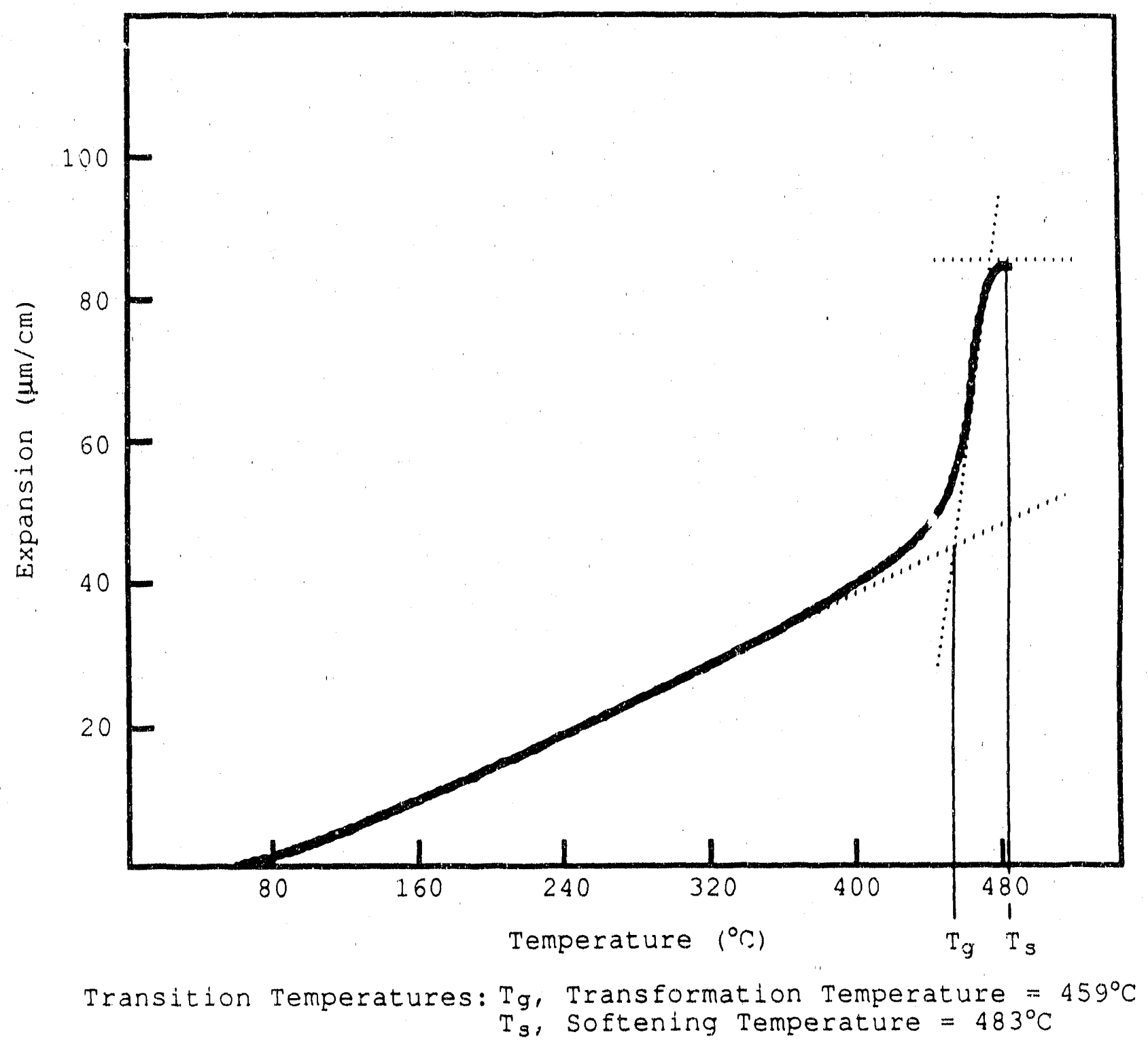


PART TITLE: CANISTER SPECIEICATIONS

ITEM TITLE: 2.1 MATERIAL, SPECIEICATION

\subsection{MATERIAL SPECIEICATION}

The waste form canister and any secondary canister applied by the producers shall be fabricated from austenitic stainless steel. The ASTM alloy specification and the composition of the canister material, the secondary canister material, and any filler material used in welding shall be included in the WCP. Documentation of compliance shall be included in the production Records.

\section{Rationale}

The repository must have a complete materials inventory to evaluate longterm performance under repository conditions. Austenitic stainless steel has been selected as the canister material. This specification acknowlodges that fact and establishes the repository's interest in this interface. The current rolo of the canister as part of the engineered barrier system does not require the canister to act as a post-closure engineered barrier; therefore, the primary requirement of the canister material specification is to ensure that the canister material does not have an adverse impact on waste package performance. By specifying austenitic stainless steel manufactured to ASMM specifications, this requiranont is met. Additionally, identification of the materials is necessary to assure that the canister material, and the material of any otber component (i.e., secondary canisters and welding fillers), are compatible with other materials in the repository.

Compdiance Strategy

The DWPE will ensure that the materials in the procured canister assembly meet the specification through a combination of component specifications, and inspections to ensure that these component specifications are met. Procurement documents for the DWPE canisters require that all material used in fabrication of the canisters shall meet the compositional requirements of the appropriate ASTM or ASME designations. All of these materials are austenitic stainless steel in nature. The procurement documents also require trat material certifications be provided tr DWPE for the metal heat used for fabrication of each component. The canisters are to be inspected by a Supplier surveillance Representative (SSR) prior to shipment to DWPE. This inspection includes verification of documentation on the compositions of canister materials. 
WSRC-SW4-6

Part 4

Item 100

Page 2 of 8

Date: $8 / 91$

Revision $1 B$

\section{PART TITLE: CANISTER SPECIEICATIONS}

\section{ITEM TITLE: 2.1 MATERIAL SPECIEICATION}

At the present time, the DWPE has reserved space in the welding cell for equipment to package a faulty glass-filled canister in a secondary canister. Equipment and process development have been suspended because of the very unlikely nature of the need for such equipment. If, at a later date, it is determined that a secondary canister is needed, equipment and process development will be reinitiated. Information on the secondary canister would then be supplied in a revision to the WQR. Any secondary canister would require use of the same materials specified above.

\section{Implementation}

The tasks planned to satisfy this specification are outlined in Eigure 4.100.1. These are:

- Specification of only austenttic stainless steel materials in the canister procurement documents.

- Delivery to the DWPE of documented certification that these material specifications have been met, by the vendor.

- Verification that only austenitic materials have been used.

Specification of Canister Materials

The current procurement specifications for the canisters require that the various parts of the canister assembly be fabricated from the following materials.

Cylinder

Nozzle

Taper Plug

Neck Sleeve

Heads

Weld Plug
ASTM A240 Type 304L stainless steel.

ASTM A336 Type F304L stainless steel

ASTM A240 Type 304L stainless steel

ASTM A479 Type S21800 stainless steel (Nitronic 60)

ASTM A240 Type $304 \mathrm{~L}$ stainless steel ASTM A240 Type $304 \mathrm{~L}$ stainless steel 


$$
\begin{aligned}
& \text { WSRC-SW4-6 } \\
& \text { Part } 4 \\
& \text { Item } 100 \\
& \text { Page } 3 \text { of } 8 \\
& \text { Date: } 8 / 91 \\
& \text { Revision } 18
\end{aligned}
$$

PART TITLE: CANISTER SPECIEICATIONS

ITEM TITEE: 2.1 MATERIAL SPECIEICATION

\author{
Repair Piug \\ Repair Cap \\ Weld Eiller Metal
}

ASTM A479 Type $\$ 21800$ stainless steel (Nitronic 60)

ASTM A479 Type 521800 stainless steel (Nitronic 60)

ASME SEA5.9 ER308I stainless steel or ANSI/AWS A5.9 ER308L

The alloy compositions corresponding to these specifications are given in Tables 4.100.1 to 4.100.5. Canisters used in non-radioactive equipment development and testing at SRL have been procured to these specifications.

Documented Certification and Verification

The canister procurement specifications require that the vendor of the canister assembly supply material certifications to DWPE for each heat of metal used. An SRS representative at the vendor's 10cation will perform verification activities to ensure that only specified materials were used. These activities will be described in the waste Form Qualification Report.

\section{Decumentation}

The WAPS require that the DWPE certify that the canisters are fabricated from the materials identified in the Waste Form Compliance Plan. The Waste Form Qualification Report will contain the canister procurement specifications, and will describe the verification activities which will be performed. The production Records will reference the procurement documents for each canister. The detailed procurement documents will include the actual specifications, purchase orders, vendor and heat identification records, certificates of analyses, and inspection records. Canisters which do not satisfy the materials specification will not be accepted for DWPE use. 
WSRC-SW $4-6$

Part 4

Item 100

Page 4 of 8

Date: $8 / 91$

Revisinn $1 \mathrm{~B}$

TABLE 4.100.1 Required chemical composition of ASTM A240 Type 304L stainless steel.

Cempenent

Carbon

Manganese

Phosphorus

Sulfur

silicon

Chromium

Nickel

other elements

Reference:

\section{Ameunt $(w+z)$}

0.030 maximum

2.00 maximum

0.045 maximum

0.030 maximum

0.75 maximum

$18.00-20.00$

$8.00-12.00$

$\mathrm{N} 0.10$ maximum

Annual Book of ASTM Standards, 1.03, American Society for Testing and Materials, Easton, MD, 62 (1987). 


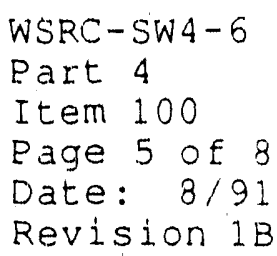

TABLE 4.100.3 Required chemical composition of ASTM A336 Type r304L stainless steel.

component.

Carbon

Manganese

Prosphorus

sulfur

Silicon

Chromium

Nickel

Other elements

Reference:
Ameunt (wt 8$)$

0.035 maximum

2.00 maximum

0.040 maximum

0.030 maximum

1.00 maximum

$18.00-20.00$

$8.00-13.00$

No specification

Annual Book of ASMM Standards, 1.05, Anerican Society for Testing and Materials, Easton, MD, 259 (1987). 


$$
\begin{aligned}
& \text { WSRC-SW4-6 } \\
& \text { Part } 4 \\
& \text { Item } 100 \\
& \text { Page } 6 \text { of } 8 \\
& \text { Date: } 8 / 91 \\
& \text { Revision } 13
\end{aligned}
$$

TABLE 4.100.4 Required chemical composition of ASTM A479 Type

S21800 stainless steel (Nitronic 60).

\section{cemponent}

Carbon

Manganese

Phosphorus

S'difur

Silicon

Chromium

Nickel

Other elements

Reference:
Amount $\left(w+\frac{q}{2}\right)$

0.10 maximum

$7.00-9.00$

0.060 maximum

0.030 maximum

$3.50-4.50$

$16.00-18.00$

$8.00-9.00$

$\mathrm{N} 0.08-0.18$

Annual Book of ASTM Standards, 1.J4, American Society for Testing and Materials, Easton, MD, $361(1987)$. 


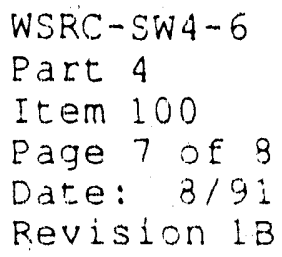

TABLE 4.100 .5

Required Chemical Composition of ASME SEA5.9

ER308L and ANSI/AWS A5.9 ER308L Stainless Steel.

Amount $\left(w+\frac{8}{8}\right)$

Cempenent
Carbon
Manganese
Prosphorus
Sulfur
Silicon
Chromium
Nickel
Molybdenum
Copper
Iron
Other elements
Reference:

ASME SEA $5.90^{1}$

0.03 maximum

$1.0-2.5$

0.03 maximum

0.03 maximum

$0.30-0.65$

$19.5-22.0$

$9.0-11.0$

0.75

0.75 maximum

$---$
ANSI/ANS_A $22^{2}$

0.03 maximum

$1.0-2.5$

0.03 maximum

0.03 maximum

0.03 maximum

$19.5-22.0$

$9.0-11.0$

0.5 maximum

0.5 maximum

remainder

No specification

1. Aswe Boiler and Pressure Vessel Code, Section II, Rart C, American Soclety of Mechanical Engineers, United Engineering Center, 345 East 47 th St., New York, NY 10017, (1986).

2. Amorican National Standards Institute/American Wolding standard, Section A.5.9. 


$$
\begin{aligned}
& \text { WSRC-SW4-6 } \\
& \text { Part } 4 \\
& \text { Item } 100 \\
& \text { Page } 8 \text { of } 3 \\
& \text { Date: } 8 / 91 \\
& \text { Revision } 1 \text { B }
\end{aligned}
$$

EIGURE 4.100 .1

Tasks planned to satisty specification 2.1, Material Specification.

Specify materials in canister procurement documents. [DWPF]

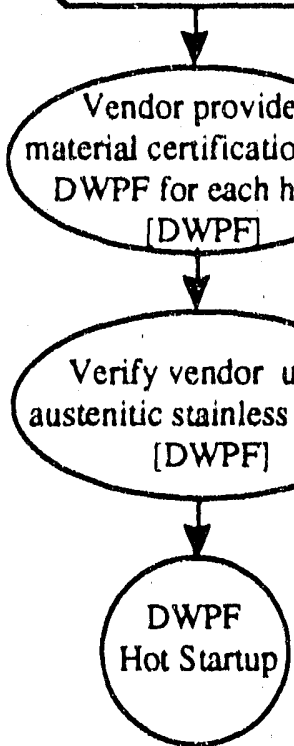

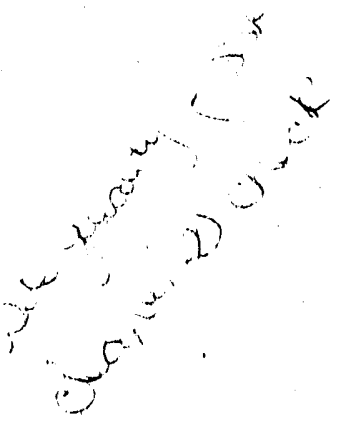


PART TITLE: CANISTER SPECIEICATIONS

ITEM TITLE: 2.2 EABRICATION AND CLOSURE SPECIEICATION

\subsection{FABRICATION AND CLOSURE SFECIFICATION}

The canister fabrication methods, as well as those for any secondaxy canister applied by the producer, shall be identified in the WCP and documented in the WOR. The outermost closure shall be leaktight to $1 \times 10^{-4} \mathrm{~atm}-\mathrm{cc} / \mathrm{sec}$ helium. The method for demonstrating compliance shall be described by the producer in the WCP and documented in the Production Records.

\section{Bationale}

The sealed canister is designed to provide crnfinement of the waste and protection of the waste form from contact with externally derived liquids and gases until the canister is sealed in a ro.pository container. The canister itself is not intended to meet a post-closure containment requirement. A leak rate of less than $2 \times 10^{-4}$ atm-cc/sec has been established as being sufficient to prevent water from entering the canister. A leak rate of $10^{-4}$ atm-cc/ sec (air) bas boen established as the container failure criterion for repository post-closure service. Thus, a final closure leakrate specification of $10^{-4} \mathrm{~atm}-\mathrm{cc} / \mathrm{sec}$ (helium) for canisters of HLW glass is considered to be both conservative and demonstrable.

\section{Cempliance Strategy}

The DWPE will comply with this specification by ensuring that both the canister itself, and the closure weld of the canister made after the canister is filled with glass, are of high integrity. The integrity of the canister itself will be ensured by specifications on the components and on the method of fabrication of the canister assembly, and verification to ensure that these specifications are met. The integrity of the final closure weld applied in the DWPE will be ensured by close control of the welding process, and inspection of the weld after closure.

Implementatiden

The tasks planned to satisfy this specification are outlined in Eigure 4.200.1. They are:

- Specification of the methods of fabrication in the canister 
WSRC-SW $4-6$

Part 4

Item 200

Eage 2 of 3

Date: $8 / 91$

Revision $1 \mathrm{~B}$

PART TITLE: CANISTER SPECIEICATIONS

ITEM TITLE: 2.2 EABRICATION AND CLOSURE SPECIEICATION

procurement speciflcations.

- Verification that the specifications have been met by the vendor.

- Development of the resistance welding process for closing the canister.

- Performance of a parametric study with the DWPE welder to determine the operating limits for the welding process. This study will be performed as part of the Startup Test Program.

- Performance of studies to verify the leaktightness of welds produced under production conditions within the operating limits. This study will also be performed as part of the startup Test Program.

Methods of Eabrication.

As shown in Eigure 4.200.2, the canister is fabricated from 304L stainless steel rolled plate, a dished bottom head, a domed top head, and a head nozzle containing a combined lifting and welding flange. These components are welded together to form a canister $300 \mathrm{~cm}(118 \mathrm{in}) \mathrm{high}$.

The specifications for procurement of the DWPE canister assembly detail the requirements for fabrication. The main cylinder is to be fabricated from rolled plate which has been hot-rolled, annealed, and pickled. Canister heads (top and bottom) are to be hot-rolled, annealed, and pickled, formed into shape, then solution annealed, and reformed in the same die. The nozzle, tapered plug, and the Nitronic 60 sleeve are all to be machined to tolerances. The canister nozzle, top head, cylinder, and bottom head will then be welded together.

\section{Verification}

As currently specified, all welding, welding procedure qualifications, repair, electrodes, and welder performance tests used in the fabrication of the canisters, are to be performed in accordance with ASME Section IX, Summer 1989 Addenda - Welding and Brazing Qualifications, unless otherwise specified in the canister 
WSRC-SWA- 万

Part 4

Item 200

Page 3 of 3

Date: $8 / 91$

Revision $1 \mathrm{~B}$

PART TITLE: CANISTER SPECIEICATIONS

ITEM TITLE: 2.2 FABRICATION AND CLOSURE SPECIFICATION

procurement document. The canister fabrication welds are to be made according to drawing and procedural specifications. A representative of the DWPE will approve all weld procedures prior to fabrication. A Supplier surveillance Representative will verify that the proceciures have been followed by inspections conducted at the vendor's shop.

After fabrication, all welds will be subjected to a liquid penetrant examination per ASME Section V. Evaluation will be in accordance with Appendix 8 of ASME Section VIII. Al.1 full penetration butt welds will be subjected to a radiographic examination per ASME section V. Evaluation will be in accordance with UW-51 of ASME Section VIII.

Each canister will be pressure tested by the vendor. The pressure test used will be a $1.30 \mathrm{MPa}$ (188 psi) pneumatic test with air or dry nitrogen. After the pressure test each canister will also be helium leak tested by the vendor. Only canlsters with leak rates less than $1 \times 10^{-7} \mathrm{~atm} \cdot \mathrm{cc} / \mathrm{sec}$ will be acceptable.

Canisters received by the DWFE will be inspected for gross damage, surface defects, and surface cleanliness. The canister procurement specifications and DWPE inspection procedures will be documented in the Waste Form Qualification Report.

\section{Development of the Resistance Welding process}

The resistance welding process has been selected as the final closure method for DWPF canistered waste forms. This technique was chosen after consideration of seven alternative processes including gas tungsten arc, gas metal arc, plasma arc, thermite, electron beam, laser beam and friction welding. Resistance welding was selected because of its reliable high weld quality, its tolerance to wide variations in process parameters, and its relatively simple equipment needs. ${ }^{1}$

In this process, a nominal $12.7 \mathrm{~cm}(5.00$ in) diameter, $1.27 \mathrm{~cm}$ $(0.5$ in) thick, $304 \mathrm{~L}$ stainless steel plug is placed in the canister neck. A ram forces the plug down into the neck while an electric current is passed through the narrow (high resistance) contact between the canister neck and the plug. The plug is 
WSRC-SiN4 -5

Part 4

Item 200

Page 4 of 3

Date: $8 / 91$

Reviston 18

PART TITLE: CANISTER SPECIEICATIONS

ITEM TITLE: 2.2 EABRICATICN AND CLOSURE SEECIEICATION

chamferred so that when the welding ram is lowered, the plug will be self-leveliing and self-centering. The current softens (but does not melt) the metal at the contact so that a solid state weld is formed between the plug and the canister nozzle. The approximate weld conditions are a force on the ram of 330,000 newtons $(75,000$ lb), and a direct current of 225,000 amps, for 1.5 seconds.

Weld tensile strength and leak measurements have been made on upset resistance welds under a wide variety of surface conditions. An upset resistance weld with a $12.7 \mathrm{~cm}$ diameter plug and a machined canister neck is leaktight to at least $10^{-8} \mathrm{~atm} \cdot \mathrm{cc} / \mathrm{sec}$ helium (detection limit) for a hydrostatic test pressure of $34 \mathrm{MPa}$ $(5,000 \mathrm{psi})$.

\section{Rarametric study of Weld Parameters}

Considerable testing of experimental welding equipment has already been completed. These tests have shown that the parameters which affect weld quality are: the cleanliness and condition of the surfaces to be welded, the levelness of the weld plug in the nozzle, the force used for welding, the current used for welding, and the duration of the weld. These tests indicate that the range of conditions which produce acceptable welds is much wider than the range of expected operating conditions in the DWPF. Burst tests of welded specimens, and destructive examination of experimental. welds, have both shown that the welds produced in the DWPE should be of comparable strength to the base metal. These tests will be repeated using the actual DWPE equipment. These parametric studies, which will be performed during the startup. Test Program (Appendix 1.200.2), will vary the key weld parameters (time, current, force) in order to define the operating limits for the actual process equipment. Simulated (dummy) and actual canister welds will be made, helium leak tested, pressurized to rupture (burst testing), and characterized microstructurally.

Verification of operating Iimits

During the startup Test program, the range of operating parameters selected for use in the DWPF will be verified, with the DWPE operating procedures, process specialists, and the process equipment. 
WSRC - SW $4-6$

Part 4

Item 200

Page 5 of 3

Date: $8 / 91$

Revision 18

\section{PART TITLE: CANISTER SPECIEICATIONS}

\section{ITEM TITLE: 2.2 FABRICATION AND CLOSURE SPECIEICATION}

Both simulated (dummy) and actual canister welds will again be made, tested, and characterized microstructurally. This testing will demonstrate that maintaining the weld parameters (force, current, time) within operating limits will produce welds that meet this specification. The results of this testing will be reported in the WQR.

During production, the quality of the final closure weld in the DWPE will be assured through the following: use of the sleeve in the canister nozzle and a throat protector to maintain surface cleanliness during canister filling, speciflcation and inspection of the weld plug and canister nozzle before welding to ensure a good surface for welding, control of the welding process parameters (force, current, and time), visual inspection of the final weld, and measurements of the displacement of the piug during welding.

At the present time, the DWPE has reserved space in the welding cell for equipment to package a faulty glass-filled canister in a secondary canister. Equipment and process developinent have been suspended because of the very unlikely nature of the need for such equipment. If, at a later date, it is determined that a secondary canister is needed, equipment and process development will be reinitiated. Information on fabrication and closure of the secondary canister would then be supplied in a revision to the WCP. It is likely that a different closure process would be needed.

Recumentation

The Waste Eorm Qualification Report (WQR) will include the canister procurement specifications. The WQR will also include a report on the parametric testing of weld conditions and associated leak rates, and validation of the parametric testing during the Startup Test Program.

The Production Record (Appendix 1.200.1) for each canistered waste form will certify that the canister components and the entire canister assembly were fabricated according to approved drawings and procedures, and meet the procurement specifications.

The Production Record will also certify the integrity of the final closure weld made in the DWPF. The production Records will report 
WSRC-SW4-6

Part 4

Item 200

Page 6 of 8

Date: $8 / 91$

Revision $1 B$

PART TITLE: CANISTER SPECIEICATIONS

ITEM TITLE: 2.2 FABRICATION AND CLOSURE SPECIEICATION

the force, current, and duration of application of the current as recorded by the computer collecting the data from the DWPF welder. If these values are outside the range of parameters which have been shown to produce a leaktight weld, the canister weld w1l.1 be identified as a nonconforming item. Its disposition will be in accordance with the procedure outlined in Part 6, Item 800 .

\section{References}

1. B. J. Eberhard, and J, W. Kelker, "High Current Resistance Welding of Nuclear Waste Canisters," Welding Journal, 61(6), 15-9 $(1932)$. 


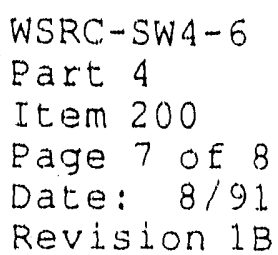

EIGURE 4.200.1 Tasks planned to satisfy speclfication 2.2 , Eabrication and Closure Spectelcation.
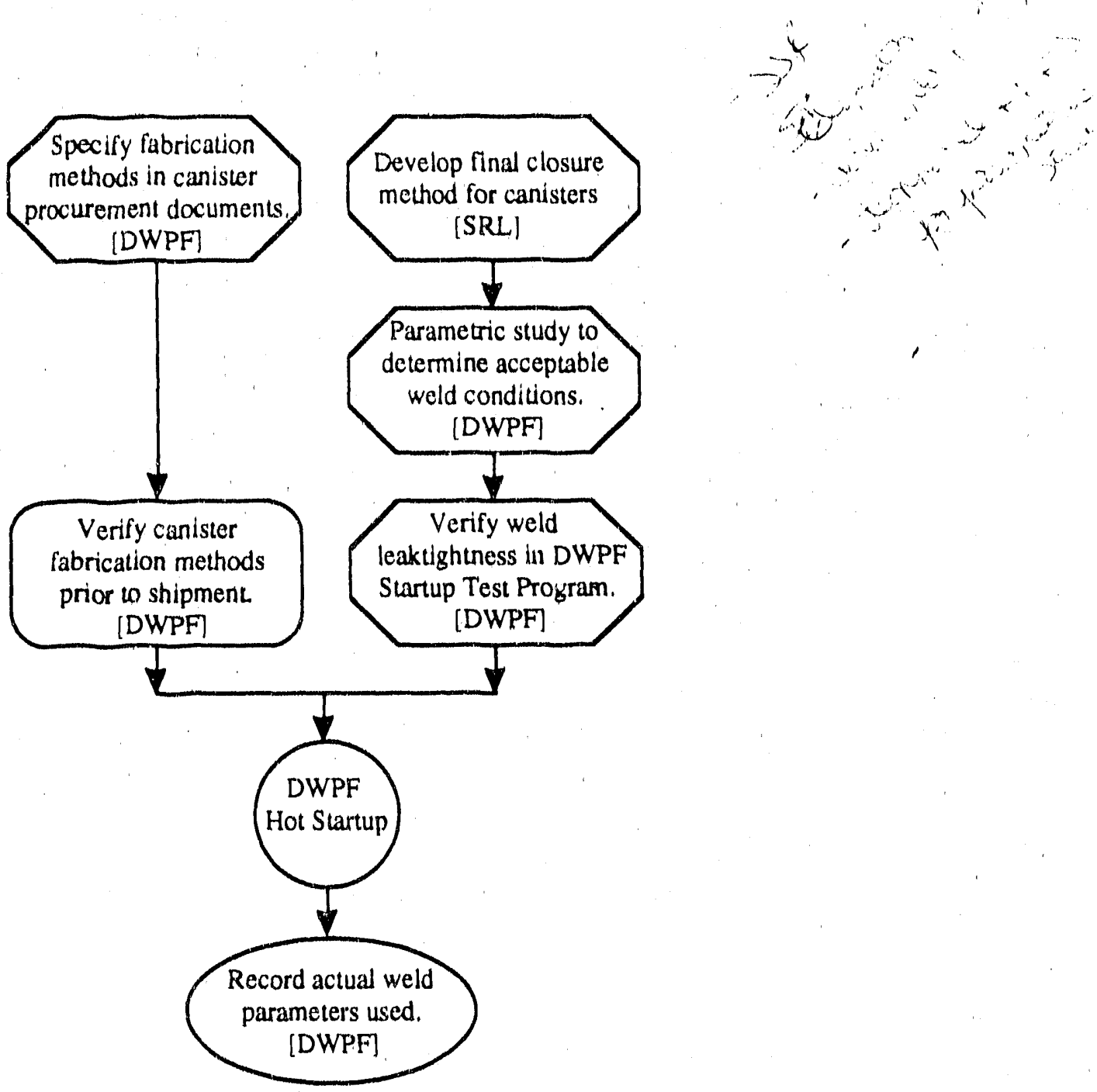
WSRC-SNA-

Part 4

Item 200

Page 8 of 8

Date: $8 / 91$

Revision $1 \mathrm{~B}$

EIGURE 4.200.2 Components and overall dimensions of the DWPE canister.

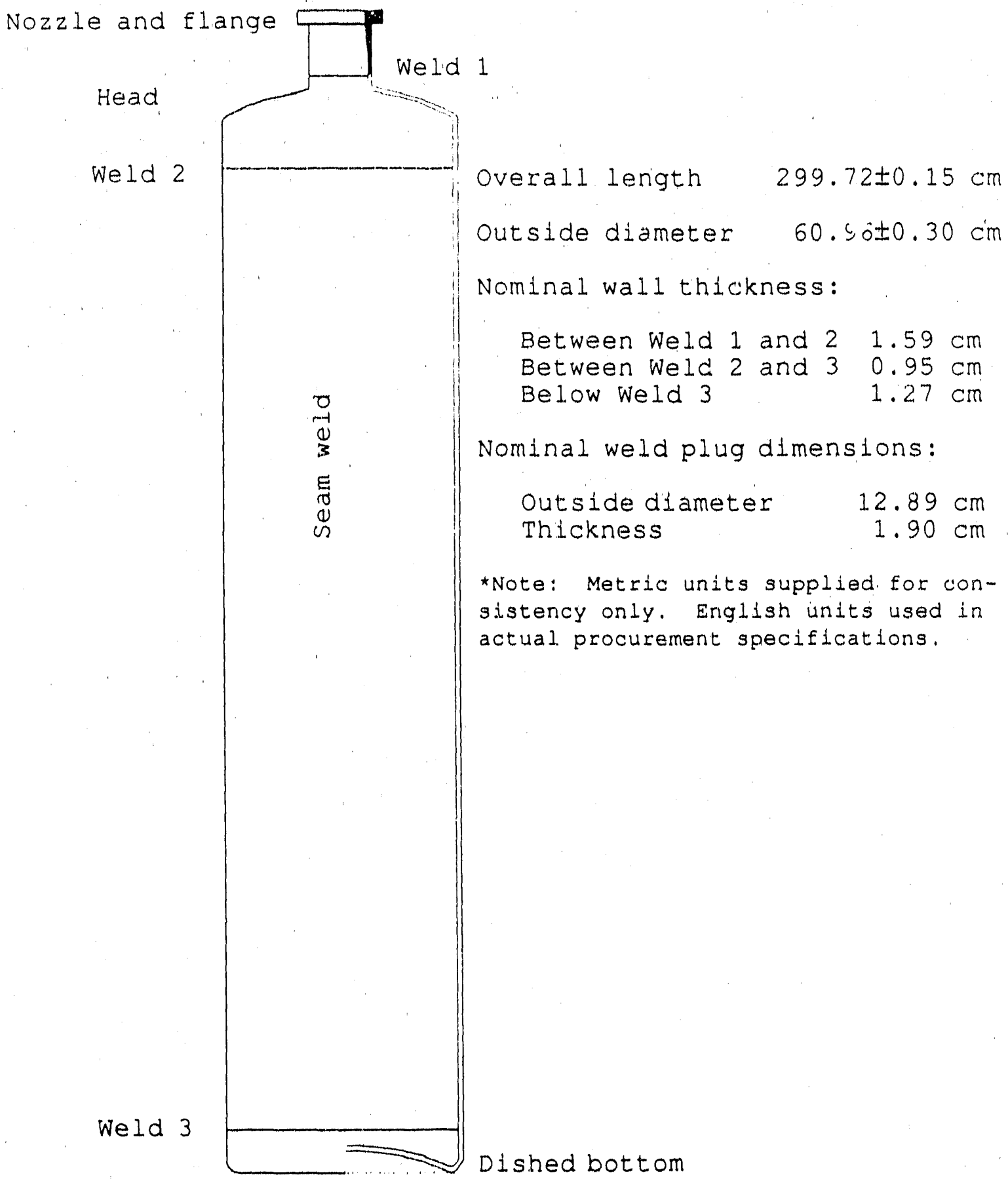


PART TITLE: CANISTER SPECIFICATIONS

ITEM TITLE: 2.3 IDENTIEICATION AND LABELING SPECIEICATIONS

\subsection{IDENTIFICATION AND LABELING SPECIFICATIONS}

\subsubsection{Identification}

The producer shall assign a unique alphanumeric identifier to each outermost canister that is produced. This alphanumeric identifier shall appear on the labels of the canistered waste form and on all documentation pertinent to that particular canistered waste form.

\subsubsection{Labeling}

Each canister shall be labeled with the identification code specified above in two locations: one visible from the top and one from the side of the canister. The identification code shall be printed in a type size of at least 92 points using a sans serif type face (or equivalent). A proposed layout shall be provided in the WCP. Labels meeting the requirements above shall be applied to the exterior of the outermost canistar and shall not cause the dimensional limits of Specification 3.11 to be exceeded. The 1abel materials and method of attachment shall be sellected to be compatible with the canister material. The label shall be designed to be logible atter filling and storage at the producer's facility, shipment to the repository, and possible lag storage at the repository in air for up to one year prior to final packaging. The method used for demonstrating compliance shall be described in the WCP. Label materials shall be described in the WQR.

\section{Rationale}

The regulatory requirements in $10 \mathrm{CFR} 60.135$ (b) (4) state "A label or other means of identification shall bo provided for each waste package. The identification shall not impair the integrity of the waste package and shall be applied in such way that the information shall be legible at least to the end of the period of retrievability. Each waste package identification shall be consistant with the waste package's permanent written records."

This specification provides a means of tying the waste package arui the canistered waste form together through closure of the repository. The 92 point sans serif type face (or equivalent) results in a letter beight and width of approximately $3 \mathrm{~cm}$ by $2 \mathrm{~cm}$ which iàs bǘñ confismed through obeervation to ba adequate dimensions 
WSRC-SW $4-6$

Part 4

Item 300

Page 2 of 8

Date: $8 / 91$

Revision $1 \mathrm{~B}$

PART TITLE: CANISTER SPECIEICATIONS

ITEM TITLE: 2.3 IDENTIFICATION AND LABELING SPECIEICATIONS

for visibility. The canister label is needed to identify the canistered waste form through storage at the producer's facility, shipment to the repository, and possible lag storage at the repository prior to final packaging. Once the canistered waste form is received at the repository, the burden of maintaining the identity of the contents shifts to the repository project.

\section{Comeliance strategy}

The identification code planned for the canistered waste forms is a six digit alphanumeric code consisting of the letter "S" followed by five numbers. The label lettering will conform to the specification.

The DWPF canister label is made of welding rod bead-welded directly to the canister surface. The welding rod is the same austenitic stainless steel composition used for canister assembly, to assure compatibility with the canister. This labeling technique has been shown suitable by fabricating sample labels, frit blasting them in a manner similar to that in the DWPF, and then establishing that they are still easily visible under process viewing conditions.

\section{Implementation}

The tasks being performed to satisfy this specification are outlined in Eigure 4.300.1. As noted in the Compliance Strategy, the alphanumeric code for DWPE canisters has been selected. The other actions performed to satisfy this specification are

- Development of a labeling method. This includes performing studies of various labels and labeling methods to choose a reference process, selecting a lettering shape and style, fabricating test labels, and confirming the visibility of the labeling scheme even after frit blasting.

- Inclusion of the labeling method in the canister procurement specifications.

- Estimation of the service life of the label. 


WSRC-SW4-6
Part 4
Item 300
Page 3 of 8
Date: $8 / 91$
Revision $1 \mathrm{~B}$

PART TITLE: CANISTER SPECIEICATIONS

ITEM TITLE: 2.3 IDENTIEICATION AND LABELING SPECIFICATIONS

\section{Development of Labeling Methed}

The reference labeling technique was chosen based on tests of the visibility of labels applied by various techniques, both before and after decontamination of the canister by frit blasting (see Part 5, Item 350). The label made by the reference technique was best able to maintain its legibility after decontamination. Tests through an aged shielding window showed that the label could be viewed remotely up to 10 feet away without magnification, and could be easily read at least 30 feet away with a $10 x$ magnification lens attached to a video camera. The label was most visible under indirect light which produced a profile shadow. Intense direct lighting tended to reduce the contrast between the label and the canister, making it more difficult to read. Given proper lighting, viewing angle was found to have little effect on label legibility.

Labeling Requirements to Candster Rrecurement specification

The canister labeling method selected by the DWPE is to bead-weld characters (using Type 308I welding rod) on the canister surface. The type face is sans serif style Megaron Medium. Letters are to be $5 \mathrm{~cm}$ high and $3.8 \mathrm{~cm}$ between centers. The canister vendor may use any method to provide uniform characters, subject to prior approval by DWPE. The alphanumeric code for identifying the DWPE canistered waste forms is a six digit alphanumeric string consisting of the letter "S" followed by five numbers. A label is placed on the top head and cylinder of each canister at the locations shown in Eigures 4.300 .2 and 4.300 .3 . After completion of labeling, characters are to have a profile height of about $0.16 \mathrm{~cm}$. The label will be inspected with the rest of the canister, and any imperfections which could trap contamination will be removed before acceptance of the canister. This is included in the canister procurement specifications for the DWPE canister, which will be included in the WQR.

\section{Estimation of Service life}

The welding rod used as the bead-welded label characters on the canister surface will be Type $308 \mathrm{~L}$ austenitic stainless steel. This is the same material used to assemble the canister (see part 
WSRC $-5 W 4-6$

Part 4

Item 300

Page 4 of 8

Date: $8 / 91$

Revision $1 \mathrm{~B}$

\section{PART TITLE: CANISTER SPECIEICATIONS}

\section{ITEM TITLE: 2.3 IDENTIEICATION AND LABELING SPECIEICATIONS}

4. Item 1.00)...The service life of the label should be comparable to that of the welds which hold the candster together, because the label will be made from the same material as the canister fabrication welds and should experience the same thermal treatment during filling. Thus, after filling the canister, the DWPF should not need to take any special precautions to protect the canister label. During the startup Test Program, the microstructures of the label and the canister welds will be characterized, and related to one another.

It is not possible for the DWPF to accurately estimate the service Iife of the label or canister without knowing the conditions of storage at the repository. The DWPE expects that the canister and its associated labels will maintain functionallty during storage in the DWPE's Glass Waste Storage Building (see Part 1, Item 300), and transport to the repository. This is based on the following:

- The canister will be at a higher temperature than the storage building. Thus, water will tend to vaporize away from the canister and condense on cooler surfaces, such as the metal =guides lining each storage location.

- The Glass Waste Storage Building will force air across the surface of each canister at all times, keeping the surface dry.

- The flow of forced air will keep the temperature relatively low, thus limiting the rate of any corrosion reaction.

- The radiation dose rate will be relatively low. In conjunction with the small amount of water vapor present near the canister surface, this implies generation of nitric acid vapor should be negligible.

If the repository establishes controls similar to those above for lag storage prior to final packaging, the canister and its label will maintain its integrity through final packaging.

Decumentation

The Waste Form Qualification Report will contain a description of the Glass Waste Storage Building, the controls to be applied to 
WSRC $-S W 4-6$

Part 4

Item 300

Page 5 of 8

Date: $8 / 91$

Revision $1 \mathrm{~B}$

PART TITLE: CANISTER SPECIEICATIONS

ITEM TITLE: 2.3 IDENTIEICATION AND LABELING SPECIEICATIONS

ensure label and canister integrity, and a report on the relationship between the label and the canister welds, which experience similar thermal histories.

Both the production Records, and the Shipping and storage Records, will identify particular canisters by the code on the label affixed to them. This code, unique to each canister, will be the key to tracing the records for each canister and canistered waste form. All of the records which support the information reported in the production Records, and the Shipping and Storage Records, will be keyed to that code. 
EIGURE 4.300.1 Tasks planned to satisfy Specification 2.3, Identification and Labeling Specification.

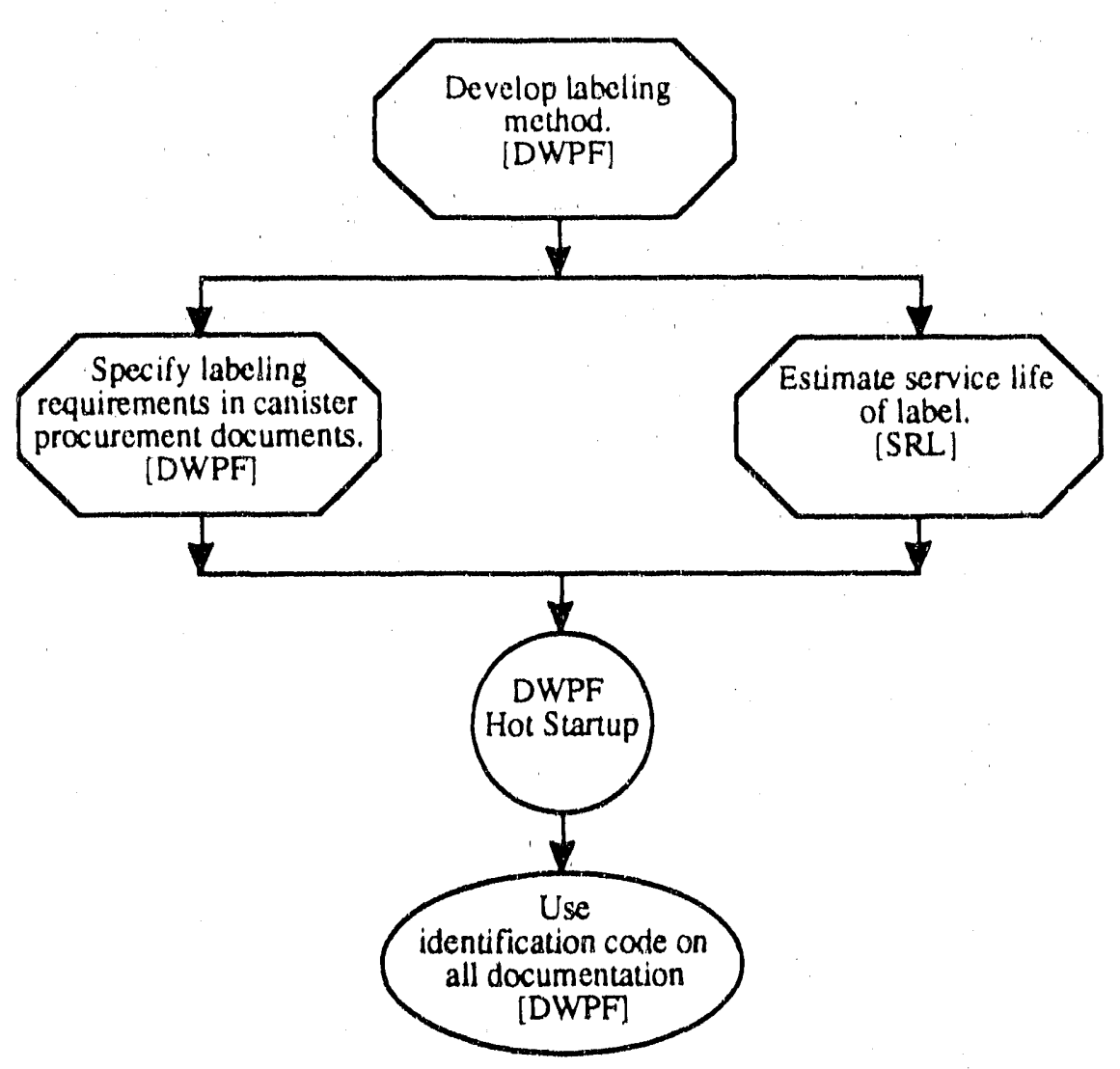


WSRC-SW4 - 6

Part 4

It.em 300

page 7 of 8

Date: $8 / 91$

Revision $1 B$

EIGURE 4.300.2 Placement of top label on DWPE canister.

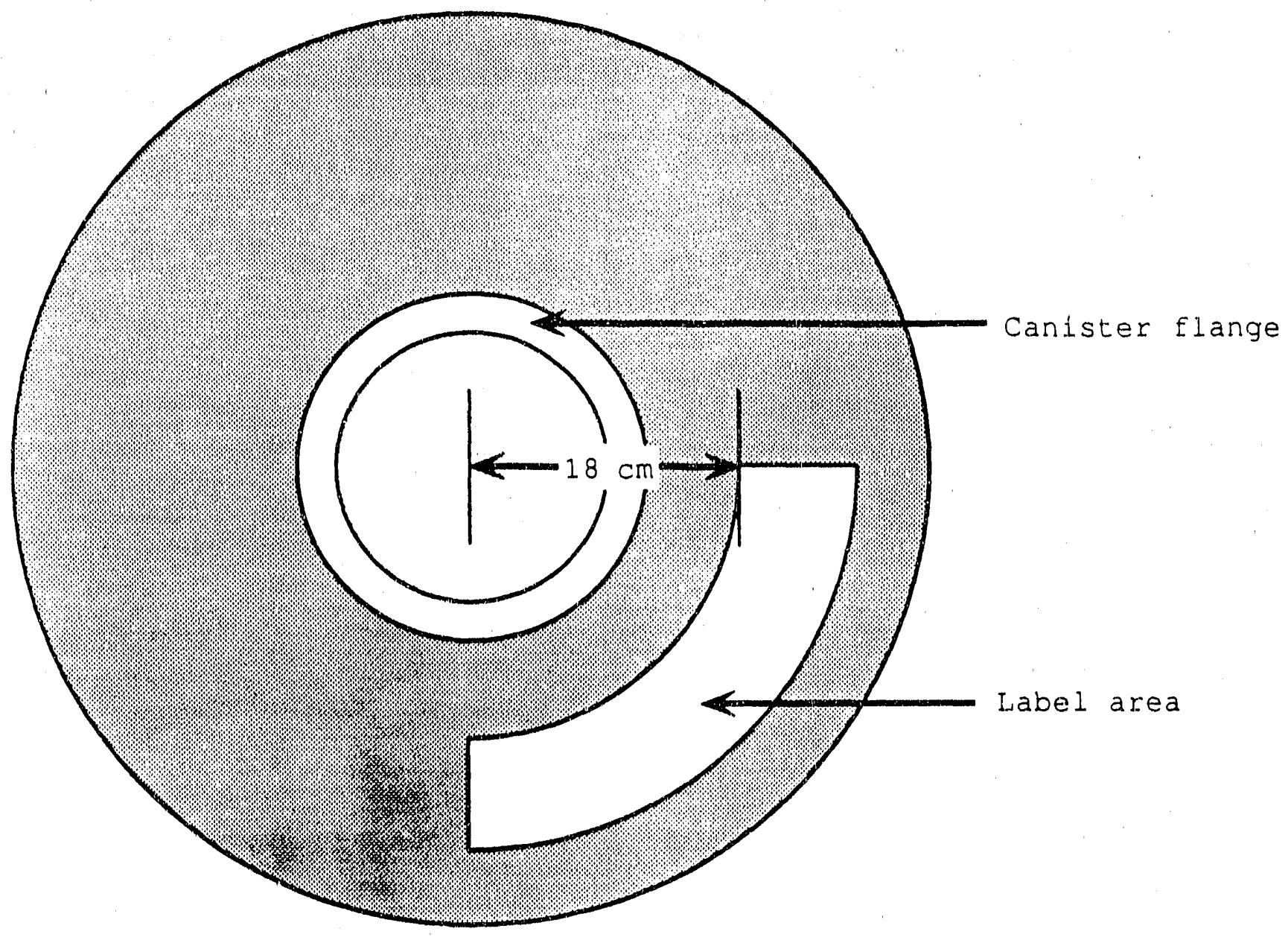

EILI CANISTER - TOP VIEW 
WSRC $-S W 4-6$

Part 4

It em 300

Page 8 of 8

Date: $8 / 91$

Revision $1 \mathrm{~B}$

FIGURE 4.300 .3 Placement of side label on DWPE canister.

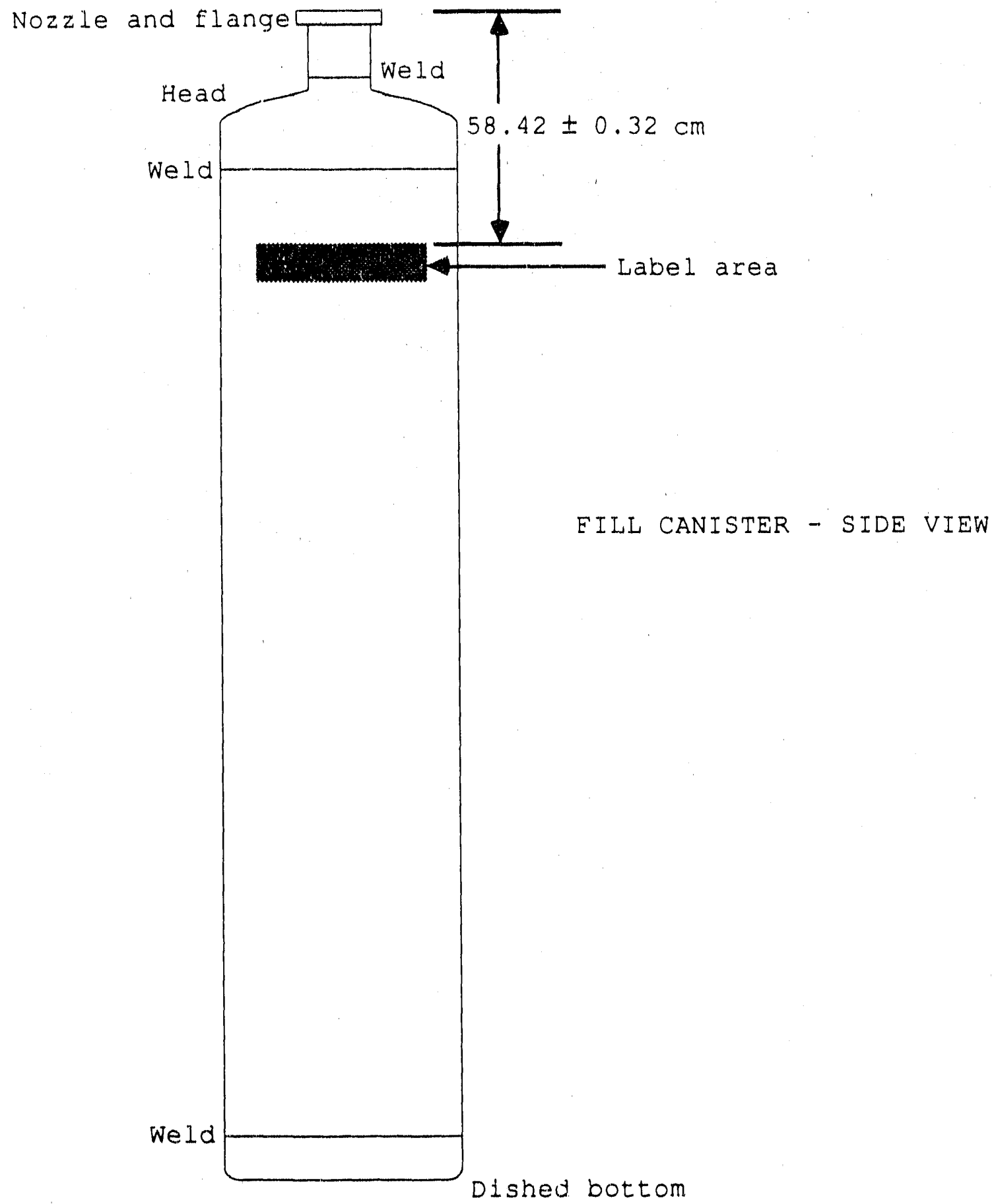


WSRC-SW4-б́

Part 5

Item 100

Page 1 of 8

Date: $8 / 91$

Revision $1 B$

PART TITLE: CANISTERED WASTE FORM SEECIEICATIONS

ITEM. TITLE: 3.1 EREE LIQUID SPECIFICATION

\subsection{FREE IIQUID SPECIEICATION}

After closure the canistered waste form shall not contain free liquids. The producer shall describe the method of compliance in the WCP and provide documentation of the ability to comply with this specification in the WQR.

\section{Bationale}

The regulatory requirements outlined in $10 \mathrm{CrR} 60.135$ (b) (2) state that, "The waste package shall not contain free liquids in an amount that could compromise the ability of the waste package to achieve the performance objectives relating to containment of HLW (because of chemical interactions or formation of pressurized vapor) or result in spillage and spread of contamination in the event of waste package perforation during the period through perranent closure."

\section{Compliance strategy}

The vitrification process, operating at. $1150^{\circ} \mathrm{C}$, with a nominal melter residence time of 65 hours, will. evaporate all free liquids from the waste feed stream as the waste is converted into molten glass. The glass pouring into the canister will be at a temperature of about $1000^{\circ} \mathrm{C}$, and the canister under a slight vacuum. Thus, free liquids will not enter the canister with the molten glass stream, and any liquids present in the canister prior to pourlng are unlikely to remain due to the heat of the molten glass and the reduced pressure.

The most likely source of free liquids in the canister is the water/frit slurry used to decontaminate the canister. A shrink-fit seal has been developed to ensure that this slurry does not enter the canister. ${ }^{1}$ This temporary seal called the Inner Canister Closure (ICC) will be inserted into the canister neck after filling, and before canister decontamination, to prevent inleakage of the decontamination slurry. Every ICC will be tested to ensure it is water tight. Administrative controls will be used to prevent the introduction of any free liquids into the candsters before or after glass filling. Tests will be performed in the facility to demonstrate the effectiveness of the controls. 
WSRC $-S W A-5$

Part 5

Item 100

Page 2 of $B$

Date: $8 / 31$

Revision $1 \mathrm{~B}$

PART TITLE: CANISTERED WASTE EORM SPECIEICATIONS

ITEM TITLE: 3.1 EREE LIQUID SPECIEICATION

\section{Implementation}

The tasks planned to satisfy this spectflcation are outlined in Eigure 5.100.1. They are

- Identiflcation of the sources of liquids in the canistered waste form.

- Demonstration that borosilicate glass does not contain free liquids, and that they cannot enter the canister with the molten glass stream.

- Development of controls to prevent the introduction of free liquids into the canister, either before or after filing.

- Development of a leaktight temporary seal to be used during canister decontamination.

- Demonstration of the effectiveness of the controls as part of the startup Test Program.

Identification of the seurces of ILiguids

SRL w111 conduct a review of the entire process to identify all of the possible sources of free liquids, and other foreign materials, in the canistered waste form. This review will begin at the canister vendor's shop, and proceed through application of the final closure weld at the DWPE.

It may be assumed that water vapor will be present inside the canistered waste form from the amblent cell air. Worst case dew point calculations, based on a $185^{\circ} \mathrm{C}$ sealing temperature and the most humid credible atmospheric conditions, indicate a maximum of 4.6 grams of water vapor will be trapped in the vapor space within DWPF canistered waste forms. The somewhat elevated steady-state temperatures expected during interim storage at the DWPE WIII prevent this water vapor from condensing. These results will be documented in the waste Form Qualification Report.

Absence of Eree Liquids In DWRE Glass

As noted in the Compliance Strategy, the high temperatures of the 
NSRC-SW4- 5

Part 5

Item 100

Eage 3 of 3

Date: $8 / 91$

Revision $1 \mathrm{~B}$

PART TITLE: CANISTERED WASTE EORM SPECIEICATIONS

ITEM TITLE: 3.1 EREE LIQUID SPECIEICATION

DWPE vitrification process make it very unlikely that process $11 q-$ uids will survive to enter the canister with the pouring glass stream. In addition, borosilicate waste glass itself contalns no free 1 iquids. The Waste Eorm Qualification Report will document that borosilicate waste glass will contain no free liquids, and that free liquids carinot enter the canister with the molten waste glass.

\section{Development ef contrels te prevent Ingress of Free Jugulds}

Based on the identification of the sources of free liquids, the DWPE will establish controls to prevent the introduction of free liquids into the canister, both before and after fliling. These will be primarily procedural (e.g., inspections), but will also include the temporary seal (described below), and the final closure weld (described in Part 4, Item 200). These controls will be described in the Waste Form Qualification Report.

\section{Development of Temperary Seal Prucess}

After filling with glass, the canister is decontaminated by blasting a slurry of glass frit at the canister surface. This is the most likely method of ingress of free liquids. The DWPE has developed a water tight temporary seal to prevent water (or other liquids) from entering the canister after flling, before the final closure weld is made. A shrink-fit seal technique was selected because it uses the heat from the glass filling operation to make the seal. It is a simple, reliable process, because it requires no additional equipment in the hot cell.

The temporary shrink-fit seal, called the Inner Canlster closure (ICC), is made at the top of the canister nozzle, after the canister has been filled with glass, and vented (to the off-gas system) for $\sim 30$ minutes to remove volatile species. Figure 5.100.2 outlines this process. The seal is made by placing the cold seal plug in the hot canister sleeve (emplaced in canister during fabrication - see part 4, Item 200). As the hot sleeve and the plug equilibrate, the hot sleeve shrinks around the plug to form a water tight seal (see Elgure 5.100.3).

Both the sleeve and the ICC plug are purchased to specifications in the canister procurement document. The sleeve is tested for 
WSRC $-S W 4-6$

Part 5

Item 100

Eage 4 of 8

Date: $8 / 91$

Revision $1 . B$

PART TITLE: CANISTERED WASTE FORM SPECIEICATIONS

ITEM TITLE: 3.1 EREE LIQUID SPECIEICATION

Leaktlghtness as a part of acceptance testing of the fabricated canister. This testing ensures that the leak test performed after insertion of the ICC Is actually a test of the seal, and not of the sleeve's tightness.

After the canister cools, the ICC (temporary seall) and sleeve to neck joint are tested for water tightness. This is done using a pressure-decay leakage detector, which has been experimentally demonstrated to be sen'stive to leaks $21 \times 10^{-6} \mathrm{~atm}-\mathrm{cc} / \mathrm{sec}$ helium. A leak rate of $<2 \times 10^{-4} \mathrm{~atm}-\mathrm{cc} / \mathrm{sec}$ helium has been experimentally established as the rate at which no water would enter the canister during decontamination. All ICCs will be tested before the canister is allowed to transfer to the Canister Decontamination Cell (see Part 3, Item 600).

If the ICC is not water tight, it will be re-worked before transfer of the canister is allowed. In the re-work process, the flange 15 heated rapldiy so that it expands away from the sleeve and plug. They then fall inside the canister. Oversized cylindrical repair plugs are then shrink-fit in the nozzle to replace the orighnal seal. After re-work, the ICCs are then retested. If an acceptable leak rate cannot be achieved for any canister, even after re-work, the glass-filied canlster will be treated as a nonconforming item, and dispositioned according to part 6 , Item 300 .

Demonstration ef Effectiveness ef controls

As part of the Startup Test Program (see Appendix 1.200.3), severa. filled cantsters will be tested for the presence of liquids, and other foreign materials. The purpose of the examination is to demonstrate the effectiveness of the controls established by the DWPE.

\section{Decumentation}

The Waste Form Qualification Report will document that free liquids will not enter the canister with the stream of molten glass, and that there are no free liquids in borosilicate waste glass. This will include the results of testing of glass heated to temperatures up to the glass transition temperature to show that no free liquids are generated, as well as other experimental evidence of the absence of Iiquids in borusilicate waste glass. 
WSRC - SW $4-6$

Part 5

Item 1,00

Page 5 of 8

Date: $8 / 91$

Revision $1 B$

PART TITLE: CANISTERED WASTE FORM SPECIEICATIONS

ITEM TITLE: 3.1 EREE LIQUID SPECIEICATION

The WQR will also include a report on the controls used to keep free liquids out of the canlstered waste form, including data from non-radioactive testing on the leak rate of the temporary canister closure. This testing will validate the previous results which showed that acceptable leak rates (< $\left.2 \times 10^{-4} \mathrm{~atm}-\mathrm{cc} / \mathrm{sec}\right)$ hellum would prevent the entrance of water into the canister. The results of testing canisters filled under simulated production conditions will also be reported.

The Production Record for each canistered waste form w111 include the results of the leak test of the temporary canister closure in the canistered waste form prior to decontamination.

\section{Beferences}

\section{J. W. Kelker, Development of the DWPr Canigter Temporary}

Shrink-it Seal, USDOE Report DP-1720, E. I. Du Pont de Nemours, Inc., Savannah River Laboratory, Alken, SC (1986). 

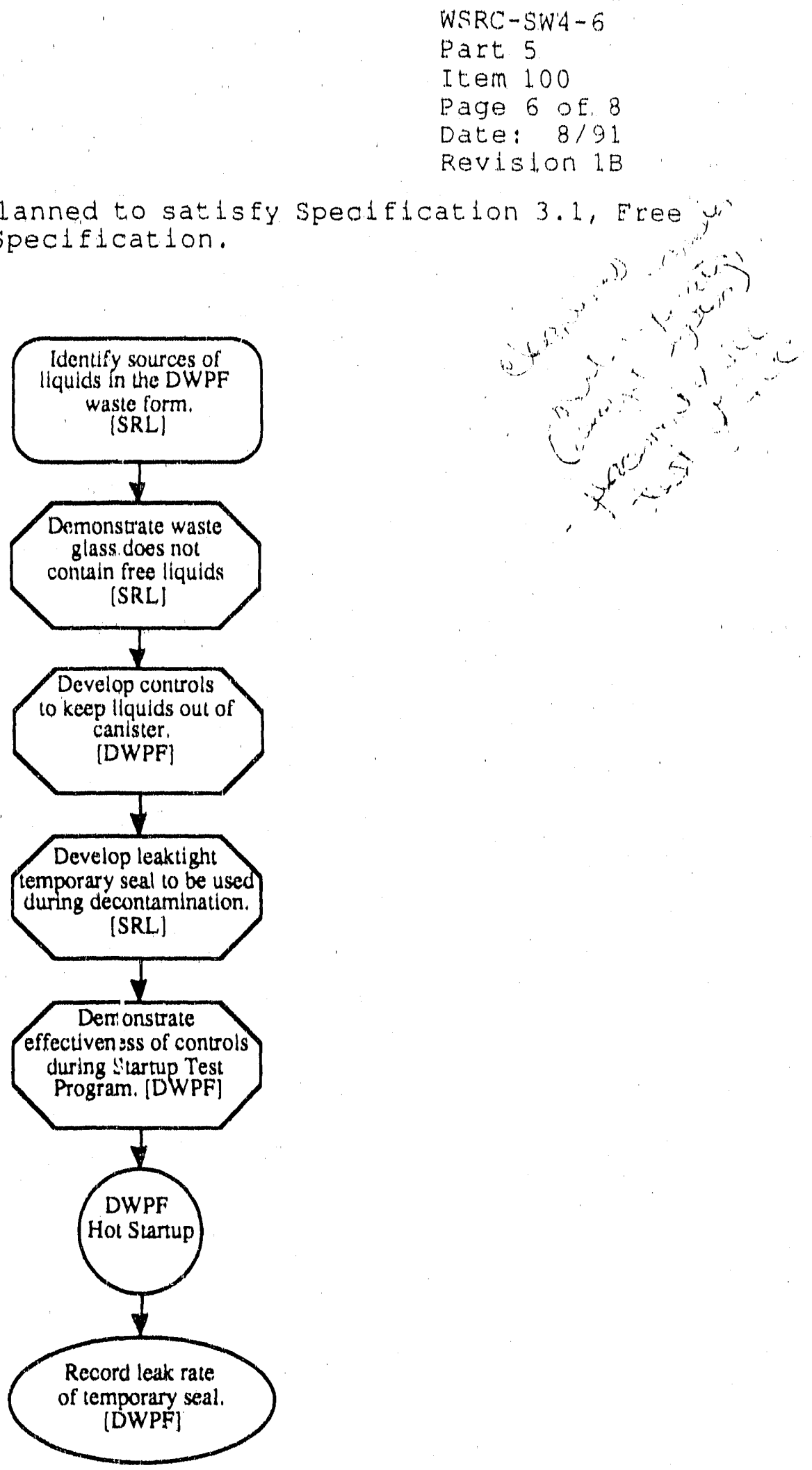


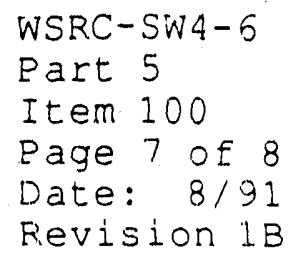

EIGURE 5.100.2 Inner Canister Closure (temporary seal) process.

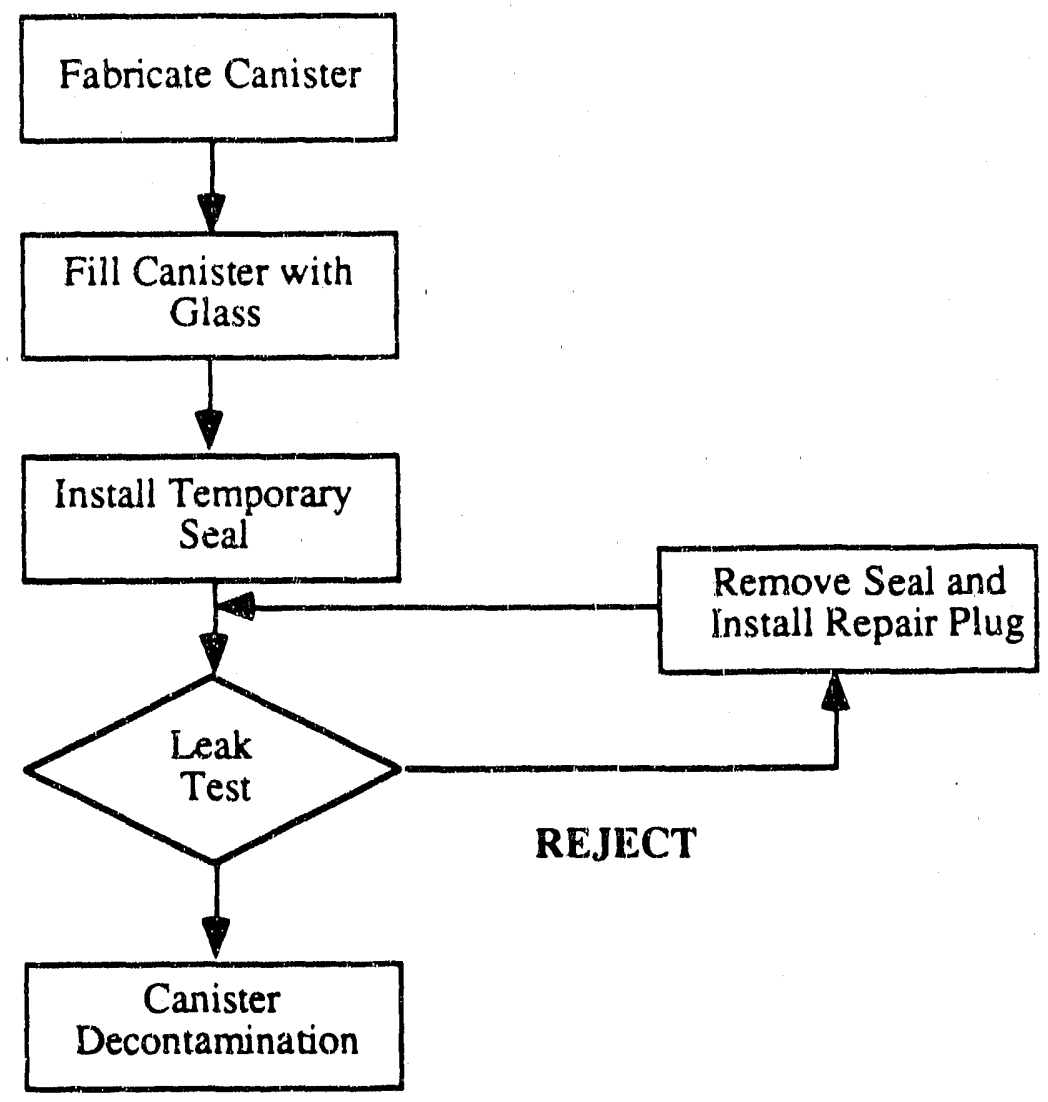


WSRC $-S W \cdot 4-6$

Part 5

Item 100

Page 8 of $B$

Date: $8 / 31$

Revision $1 \mathrm{~B}$

EIGURE 5.100.3 Completed temporary shrink-Eit seal.

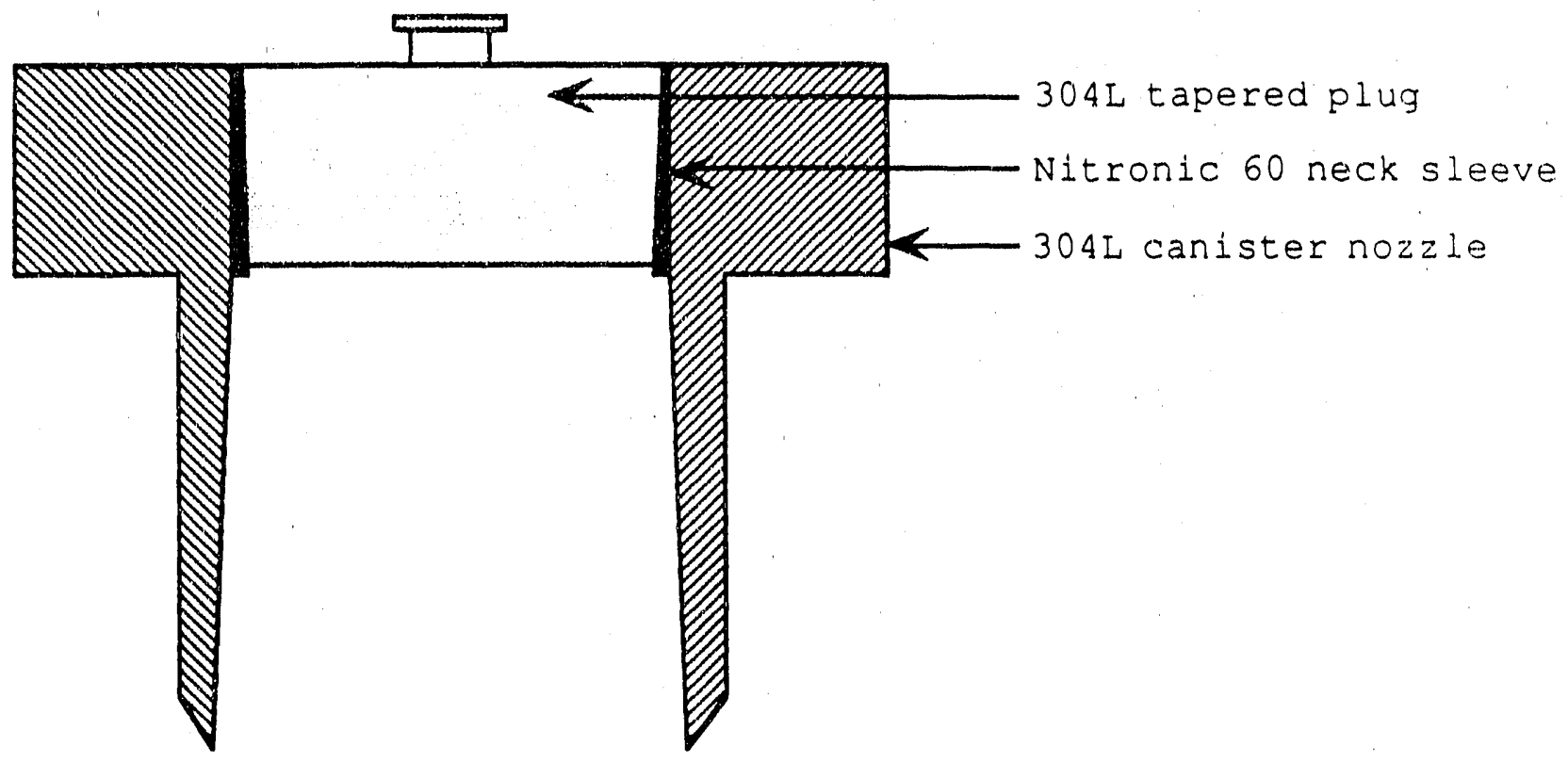


WSRC - SW $4-6$

Part 5

Item 150

Page 1 of 6

Date: $8 / 91$

Revision 18

PART TITLE: CANISTERED WASTE EORM SPECIEICATIONS

ITEM TITLE: 3.2 GAS SPECIEICATION

\subsection{GAS SPECIEICATION}

After closure, the canistered waste form shall not contain free gas other than air, cover and radiogenic gases. Cover gases shall be helium, argon, other inert gases, or air. The internal gas pressure immediately after closure shall not exceed $150 \mathrm{kPa}$ (22 psia) at $25^{\circ} \mathrm{C}$. The producer shall describe the method of compliance in the WCP and shall document compliance in the WOR as well as the quantities and compositions of any gases that migh. accumulate inside the canister after the canister has been subjected to temperatures up to the glass transition temperature.

The producer shall also document in the wQR the quantities and compositions of any gases that might accumulate inside the canisters as a result of radioactive decay prior to delivery to the repository and up to 1100 years thereafter.

\section{Rationala}

The regulatory requirements in $10 \mathrm{CFR} 60.135$ (2) require that "packages for alw shall be designed so that in-situ chemical, physical, and nuclear properties of the waste package...do not compromise the function of the waste packages..." and "The design shall include... consideration of . . . oxidation/reduction reactions, corrosion, hydriding, gas generation, thermal effects ....radiolysis, radiation damage..." In order to demonstrate compliance with the regulations, waste package designers require information on gas generation potential of the waste form.

The intent of this specification is to ensure that gas pressure will not build up inside the container and contribute to loss of containment and dispersion of radionuclides. This specification provides a limit to initial gas pressure and information from which to index the calculation of gas pressure build-up with time due to nuclear decay and temperature changes.

The value for the maximum initial gas pressure, $150 \mathrm{kPa}$ (22 psia), was chosen because it has the following attributes: it is low enough to procludo significant stresses in the canister wall arising from internal pressurization, both initially and after the anticipated bolium production from alpha docay ovar the containment period; also, it avoids introducing unnecessary restrictions that 
WSRC-SW4 - 6

Part 5

Item 150

Page 2 of 6

Date: $8 / 91$

Revision 18

PART TITLE: CANISTERED WASTE EORM SPECIEICATIONS

ITEM TITLE: $\quad 3.2$ GAS SPECIEICATION

will not materially contribute to the overall function of the canistered waste form in the repository.

In general, an internal pressure $P$ in a cylindrical vessel of diameter $D$ and wall thickness $t$ produces tensile hoop stress of

$$
\sigma_{R}=P D / 2 t
$$

and a tensile longitudinal stress of

$$
\sigma_{\mathrm{I}}=\mathrm{PD} / 4 \mathrm{t}
$$

in the wall of the vessel. For a vessel made from Type $304 \mathrm{~L}$ stainless steel, the yield strength at $500^{\circ} \mathrm{C}$ would be at least 96 MPa (14,000 psi). The more rapid cooling of the canister wall than the bulk of the glass after pouring as well as differences in the coefficients of thermal expansion of the two materials are expocted to lead to tensile thermal stresses approaching or exceeding the yield strength of the stainless steel. In order for the stresses due to internal pressurization to be insignificant in comparison, it would be sufficient to limit them to a small percentage of the yield strength. If the hoop stress is limited to 10 percent of the yield strength at $500^{\circ} \mathrm{C}$ or $9.6 \mathrm{MPa}$ (1400 psia), the maximum internal pressure, based on a $1 \mathrm{~cm}(3 / 8 \mathrm{in}$.) thick wall, would be $300 \mathrm{kPa}\left(44 \mathrm{psia)}\right.$ at $500^{\circ} \mathrm{C}$, which is equivalent to $116 \mathrm{kPa}(17 \mathrm{psia})$ at $25^{\circ} \mathrm{C}$.

The maximum pressure increase due to belium release from alpha decay after 1000 year has been calculated to bo less than $7 \mathrm{kPa}$ (1 psi); therefore, an initial pressure less than about $123 \mathrm{kPa}$ (18 psia) would therefore appear to be conservative. With these guidelines, a value of about 1.5 atmospheres, or $150 \mathrm{kPa}$ (22 psia), was cbosen as conservative and practicable. In actuality, the pressure (ovaluated at $25^{\circ} \mathrm{C}$ ) immediatoly after canister sealing is expected to be much less than $150 \mathrm{kPa}$ (22 psia), due to cooling after soaling.

\section{comoliance strategy}

The DWPF will exclude free gases (other than air, cover, and radiogenic gases) from the canistered waste form through a combination of physical and administrative control measures. Administrative controls will be used to prevent the introduction of any gases into the canisters after filling and sealing. Physical barriers 
WSRC $-5 W 4-6$

Part 5

Item 150

Page 3 of 6

Date: $8 / 91$

Revision $1 \mathrm{~B}$

PART TITLE: CANISTERED WASTE EORM SPECIEICATIONS

ITEM TITLE: 3.2 GAS SPECIEICATION

will be used to prevent the ingress of extraneous (non-radiogenic) gases. The amounts of gases generated due to radioactive decay will be calculated.

Implementation

The tasks planned to satisfy this specification are outlined in Eigure 5.150.1. These are

- Identification of the sources of free gas.

- Demonstration that borosilicate glass does not contain free gas, and that it cannot enter the canister with the molten glass stream.

- Demonstration that exposure of the glass to the glass transition temperature will not release free gas.

- Calculation of the amount of gas generated radiogenically.

- Development and demonstration of controls to ensure that free gases are not introduced into the canister.

Identification of sources of Eree Gas

The canister is filled with glass, and the temporary canister closure is emplaced, in the air atmosphere in the DWPE melt cell. No cover gas is used for welding. The only sources of gas are the waste glass itself, the ambient cell atmosphere, and the helium used in leak testing.

Absense of Eree Gas in DWRE Glass

Borosilicate waste glass itself contains no free gas, tue to the nature of the vitrification process. The Waste Form Qualification Report will document that borosilicate waste glass will contain no free gas, and that free gas cannot enter the canister with the molten waste glass.

Effects of Expesure te Glass Transition Temperature

The gases that might be generated at temperatures up to the tran- 
WSRC - SW $4-6$

Part 5

Item 150

Page 4 of 6

Date: $8 / 91$

Revision $1 \mathrm{~B}$

PART TITLE: CANISTERED WASTE EORM SPECIFICATIONS

ITEM TITLE: 3.2 GAS SPECIEICATION

sition temperature will be determined from both the technical literature, and new experimental evidence. All available evidence indicates that the canistered waste form does not contain free gas. DWPE glass may release small amounts of volatile materials upon exposure to $\mathrm{Tg}$, which will recondense when the canistered waste form cools. The composition and amounts of such materials will be reported in response to specification 3.9 (Part 5, Item 600).

\section{Badiegenic Gas Generation}

During long-term storage the canistered waste form will be continuously irradiated by beta-gamma emissions from fission products and by alpha emissions from transuranic nuclides. Calculations indicate that approximately $2 \times 10^{5}$ years of storage are required to produce enough helium to increase the gas pressure to 7 psig. Any helium that enters the canister during leak testing would not contribute substantially to this limit. These results will be documented in the Waste Form Qualification Report.

\section{Controls to Exclude Eree Gas}

Administrative controls will be used to prevent nonconforming gases from entering the canister prior to sealing. The leaktight temporary seal described in Part 5, Item 100, and the final closure weld described in part 4, Item 200, will prevent gases from entering the canister after closure. As indicated in Part 5, Item 100, during the Startup Test Program, several fllled canisters will be tested for the presence of free gas, and other foreign materials. The purpose of the examination is to demonstrate the effectiveness of the controls established by the DWPE.

\section{Decumentation}

The Waste Eorm Qualification Report will include a report on the absence of free gas in borosilicate waste glass, gas generation due to exposure to the glass transition temperature, and gas generation due to radioactive decay. The WQR will also include a report on the controls to be used to prevent introduction of other gases into the canistered waste form. 


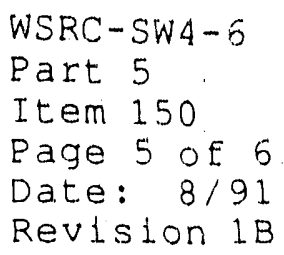

PART TITLE: CANISTERED WASTE EORM SPECIEICATIONS

ITEM TITLE: 3.2 GAS SPECIEICATION

\section{Reference}

1.R. G. Baxter, Description of Defense Waste Processing Facility Reference Waste Form and Canister, USDOE Report DE-1606, Revision 2, E. I. DuPont de Nemours and Co., Inc., Savannah River Plant, Alken, SC (1988). 


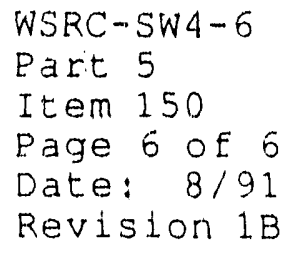

EIGURE 5.150.1 Tasks planned to satisfy Specification 3.2, Free Gas Specification.

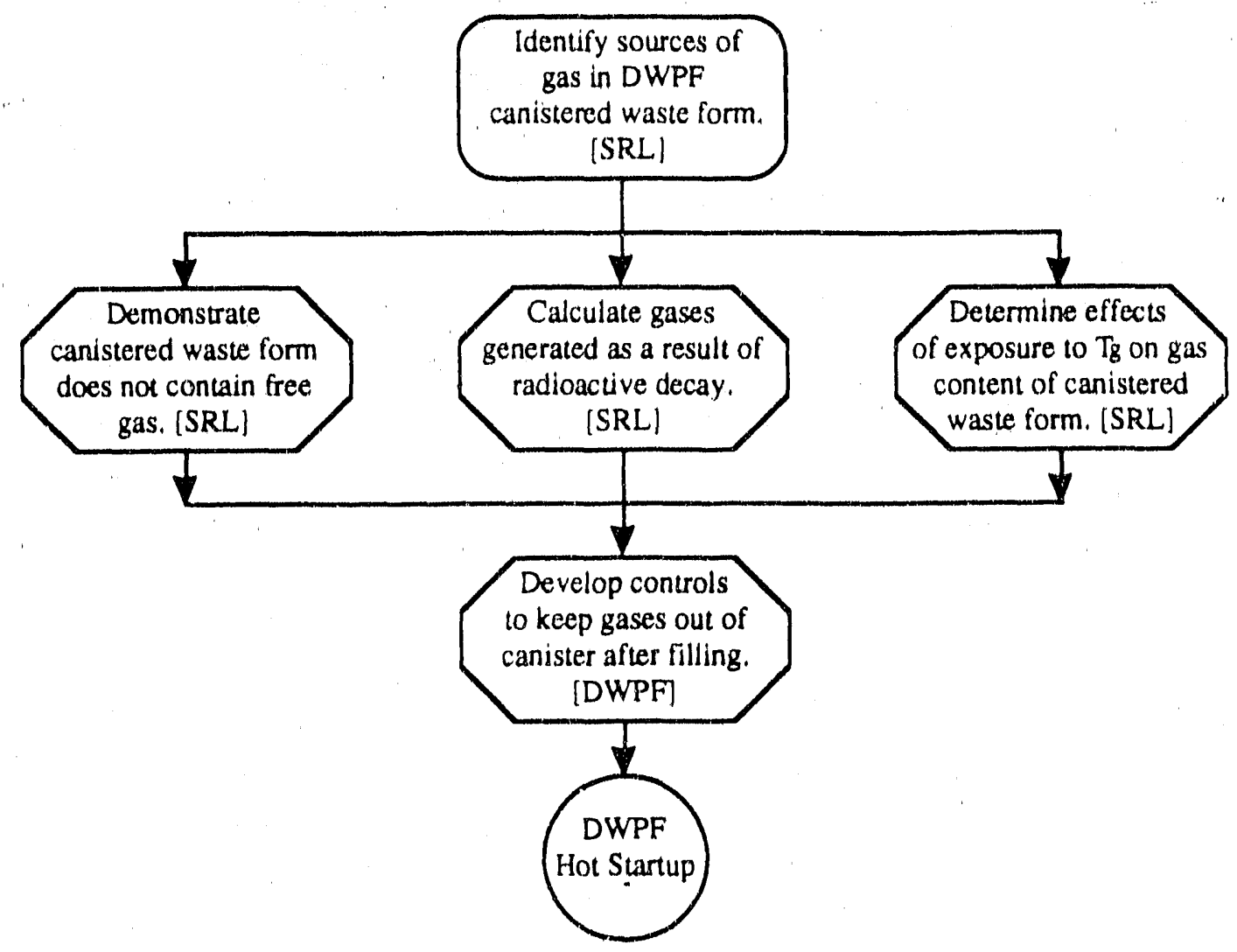


EART T:PLE: CANISTERED WASTE EORM SPECIEICATIONS

ITEM TITLE: 3.3 SPECIEICATION EOR EXPLOSIVENESS, PYROPHORICITY, AND COMBUSTIBILITY

3.3 SPECIFICATION FOR EXPIOSIVENESS, PYRORHORICITY, AND COMBUSTIBIIITY

After closure the canistered waste form shall not contain explosive, pyrophoric, or combustible materials. The producer shall describe the method of compliance in the WCP. The producer shalil present in the WQR an evaluation of the canistered waste form to demonstrate by administrative controls and other factors that, for the range of material compositions, it remains nonexplosive, nonpyrophoric, and noncombustible after having been subjected to temperatures up to the glass transition temperature.

\section{Rationale}

This specification is needed to ensure that after closure, the canistered waste form does not explode or burn during normal repository operations and accident conditions.

The regulatory requirements as outlined in $10 \mathrm{CFR} 60.135$ (b) (1) state that, "The waste package shall not contain explosive or pyrophoric materials .... in an amount that could compromise the ability of the underground facility to contribute to waste isolation or the ability of the geologic repository to satisfy the performance objectives."

The regulatory requirements on the waste package as outlined in 10 CrR 60.135 (a) (2) state that, "The design shall include but not be limited to consideration of...fire and explosion hazards." The waste form, as a component of the waste packagas must comply with this requirement.

cempliance strategy

The DWPF will prevent the presence of explosive, pyrophoric, or combustible materials in the cantstered waste form through a combination of physical and administrative control measures. These include procedures to control procurement, the nature of the vitrification process, and physical barriers to prevent the ingress of prohibited materials into the DWPE canister. The DWPE will demonstrate that waste glass remains free of explosive, pyronhor1c, or combustible materials, even if exposed to temperatur..: up to the glass transition temperature. 
WSRC- $3 W 4-6$

Part 5

Item 200

Page 2 of 5

Date: $8 / 91$

Revision $1 B$

PART TITLE: CANISTERED WASTE EORM SPECIEICATIONS

ITEM TITLE: 3.3 SPECIEICATION EOR EXPLOSIVENESS, PYROPHORICITY, AND COMBUSTIBILITY

\section{Implementation}

The tasks planned to satisfy this specification are outilned in Elgure 5.200.1. They are

- Identification of the sources of explosive, pyrophoric, or combustible materials.

- Demonstration of the absence of explosive, pyrophoric, or combustible materials in borosilicate waste glass.

- Demonstration that exposure of the waste glass to temperatures up to the glass transition temperature does not lead to the formation of explosive, pyrophoric, or combustible materials.

- Development of controls to prevent the introduction of explosive, pyrophoric, or combustible materials.

Sources of Explostve Pyropherice or Combustible Materiads

SRL will conduct a review of the entire process to identify any possible sources of explosive, pyrophoric, or combustible materials, and other forelgn materials, in the canistered waste form. This review will begin at the canister vendor's shop, and proceed through application of the final closure weld at the DWPE.

absence ef Explesives, Puropheries, or Combustibles ln Glass

Borosilicate waste glass does not contaln explosive, pyrophoric, or combustible materials because all. components of the glass have already been oxidized at high temperatures. The presence of glass in the canister is sufficient evidence of the exposure of the glass to high temperatures, because glass can only be poured into a canister while molten. In tests with simulated waste glass, it was not possible to pour waste glass at temperatures below $900^{\circ} \mathrm{C}$ from a melter similar to the DWPE melter.

\section{Effects of Expesure ef Glass to Glass Iransition Temperature}

Because the waste glass in a fllled canister has already been subfected to temperatures much greater than the glass tranistion temperature, $\mathrm{Tg}$, any further exposure of the glass to that temperature 
WSRC $-S W 4-\tilde{b}$

Part 5

Item 200

Page 3 of 5

Date: $8 / 91$

Reviston $1 B$

\section{PART TITLE: CANISTERED WASTE EORM SPECIEICATIONS \\ ITEM TITLE: 3.3 SPECIEICATION EOR EXPLOSIVENESS, PYROPHORICITY, AND COMBUSTIBILITY}

does not cause observable changes. In tests performed at SRL, and at the University of Elorlda, exposure of simulated waste gilases similar in composition to the DWPE glass to temperatures somewhat greater than the transformation temperature for several days caused no anges in the phase makeup of the glass, indicating that no new (possibly explosive, pyrophorta, or combustible) phases had formed.1-4

\section{Controls te Bar Explosives, Pyropheric, and Combustible Materials}

The DWPF is also developing controls to keep explosives, pyrophorics, and combustibles out of the candster before and after filling. The specifications for canister procurement require that the canister manufacturer clean and degrease the cantster, and cover the nozzle opening with a metal cap for shipment. This will prevent the introduction of such materials in the empty canister. Each candster w111 be inspected by DWPE personnel before it is introduced into the Vitrification Building to ensure that there are no visible prohibited materials in the canister. After filling with glass, the temporary canister closure will prevent unwanted materials from entering the canister between the time the canister is filled and the time the flnal canister closure weld is made (see Part 5, Item 100). The final canister closure weld will then prevent prohibited materials from entering the canister (see part 4, Item 200).

\section{Decumentation}

The Waste Form Qualification Report will include a report on the absence of explosives, pyrophorics, and combustibles in borosilicate waste glass. The WQR will also include a report on the controls used to keep explosives, pyrophorics, and combustibles out of the cantstered waste form, and on the effects of exposure of the glass to temperatures up to the glass transition temperature.

\section{References}

1. C. M. Jantzen, D. E. Bickford, D. G. Karraker and G. G. Wicks, "Time-temperature-transformation kinetics in SRL waste glass," Advances in Coramios - Nuclear Waste Management, B, W. A. Ross and G. G. Wlcks (eds.), 30-38 (1984). 
PART TITLE: CANISTERED WASTE EORM SPECIEICATIONS

ITEM TITLE: 3.3 SPECIEICATION EOR EXPLOSIVENESS, PYROPHORICITY, AND COMBUSTIBILITY

2. D. F. Blckford and C. M. Jantzen, "Devitrlfication Behavior of SRL Defense Waste Glass," Solentiflo Basis for Nuolear Wasto Management, VII, G. L. MCVay (ed.), Elsevier, NY, 557-66, (1984).

3. D. E. Bick ford and C. M. Jantzen, "Devitrification of Defense Nuclear Waste Glasses: Role of Melt Insolubles," J. Non-Cryst. Sol1ds, 84, 299-307 (1986).

4. D. B. Spliman, L. L, Hench and D. E. Clark, "Dovitrification and Subsequent Effects on the Leach Behavior of a Simulated Borosllicate Nuclear Waste Glass, "Nuolear and Chemical Wasto Management, 6, 107-19 (1986). 


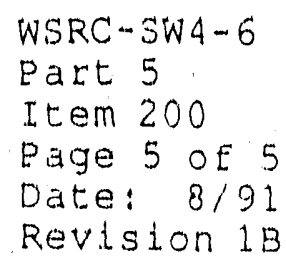

EIGURE 5.200.1 Tasks planned to satisfy speciflcation 3.3, Specification for Explosiveness, Pyrophorlcity, and Combustibility.

Idenulfy sources of explosives, pyrophorics, combustibles in DWPF waste form. [SRL)

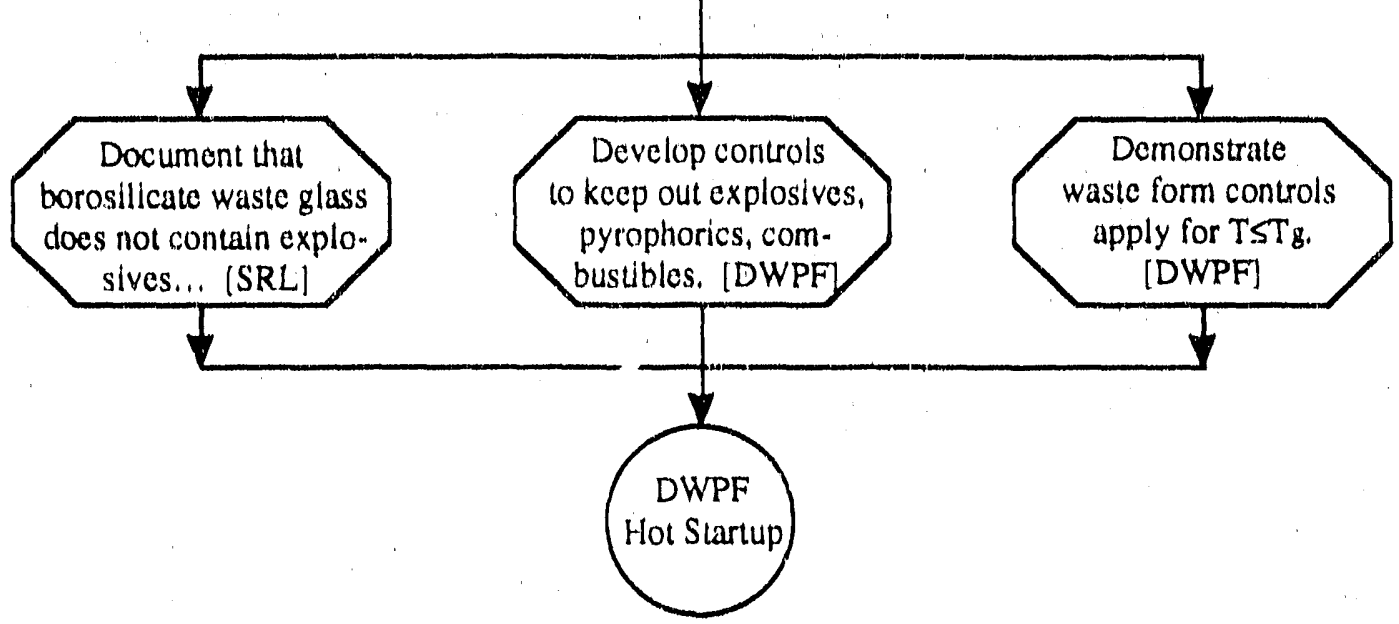


BART TITLE: CANISTERED WASTE EORM SPECIEICATIONS

ITEM TITLE: 3.4 CRGANIC MATERIALS SPEC: :ICATION

\subsection{ORGANIC MATERIALS SPECIEICATION}

After closure the canistered waste form shall not contain more than detectable amounts (approx. $10 \mathrm{ppm}$ ) of organic materials. The producer shall describe the method for complying with this specification in the WCP and document the basis for compliance in the WQR.

\section{Bationale}

This specification is needed to ensure that organio materials that tend to mobilize radionuclides by formation of complexes or generate gases due to radiolysis are not present in the canistered waste form in significant amounts.

The regulatory requirements on the waste package as outinged in 10 CFR 60.135 (a) (2) state that, "The design shall include but not be limited to consideration of the following factors: ...gas generation, radiolysis, radionuclide retardation, leaching..." The waste form, as a component of the waste package must be assessed for conpliance.

\section{compliance strategy}

It is important to prevent organic materials from entering the canister, because they could potentialiy mobilize the radionuclides by the formation of complexes or by generation of radiolytic gases. Borosilicate waste glass is an inorganic material and, thus, introduces no organic materials into the canister. The canisters themselves will be degreased by the manufacturer, using materlals specified in the canister purchase specification, prior to recelpt at SRS. The vitrification process, operating at about $1150^{\circ} \mathrm{C}$, will volatilize the organics that are present in the waste feed stream, such as the phenyl groups from the tetraphenylborate salt and formic acid (see part 2, Item 100). Administrative controls : il be used to prevent the introduction of organics into the canisters both before and after filling the canister with glass.

\section{Implementation}

The tasks planned to jatisfy this specification are outlined in Elgure 5.250.1. They are 
WSRC-SW $4-5$

Part 5

Item 250

Page 2 of 4

Date: $8 / 91$

Revision IB

PART TITLE: CANISTERED WASTE EORM SPECIEICATIONS

ITEM TITLE: 3.4 ORGANIC MATERIALS SPECIEICATION

- Identification of possible sources of organic materials.

- Development of controls to prevent the introduction of organic materials.

- Demonstration of the effectiveness of the controls during the Startup Test Program.

\section{Sources ef organic Materials}

SRL will conduct a review of the entire process to identify all possible sources of free liquids, and other foreign materials, in the canistered waste form. This review will begin at the canister vendor's shop, and proceed through application of the final closure weld at the DWPE.

Temperatures of $575^{\circ} \mathrm{C}$ and $775^{\circ} \mathrm{C}$ are used to decompose organic molecules in the standard tests ASTM D482-80 and ASTM E830-81 (tests used to assess the amount of ash from organic materials). The DWPE waste glass will be vitrified at $1150^{\circ} \mathrm{C}$. Organics present in the waste feed streams will be volatilized and become part of the melter off-gas system; they will not be incorporated into the waste glass. Organics present in the canister prior to filling will volatize when the molten glass is poured into the canister. Organics which could enter the canister after glass filling are therefore of primary concern in establishing compliance with this specification.

\section{centrols to Prevent Intreduction of erganic Materials}

There are two main types of organic materials which could be present in the canistered waste form: greases from canister fabrication and hydraulic fluid from the welding press. Controls are being developed to prevent the introduction of these, and any other, organic materials into the canistered waste form.

- Canister degreasing agents.

Each componenet of the canisters ace degreased by the manufacturer prior to final assembly. This is currently specified in the canister procurement specification, which will be included in the waste Eorm Qualification Report. 
WSRC-SWA- 6

Part 5

Item 250

Page 3 of 4

Date:' $8 / 91$

Revision $1 \mathrm{~B}$

PART TITLE: CANISTERED WASTE EORM SPECIFICATIONS

ITEM TITLE: 3.4 ORGANIC MATERIALS SEECIEICATION

- Hydraulic fluid from the canister welding process.

During press down of the temporary seal, it is possible that hydraulic fluid from the press could drip into the canister. However, the press is equipped with a drip pan designed to ensure that any dripped fluid will not enter the canister; also, the hydraulic fluid is a bright red color that is easily detected on the canister surface. The performance of the drip pan design will be reviewed, and the design re-assessed to ensure its effectiveness.

Demenstration of Effectiveness of Controls

As part of the Startup Test Program (see Appendix 1.200.3), several filled canisters will be tested for the presence of organic materials. The purpose of the examination is to demonstrate the effectiveness of the controls established by the DWPE.

Decumentation

The Waste Form Qualification Report will identify the possible sources of organics in the canistered waste form, and the controls used to exclude each from the canistered waste form. The amount of organic material found in simulated canistered waste forms produced as part of the startup Test Program will also be reported. 

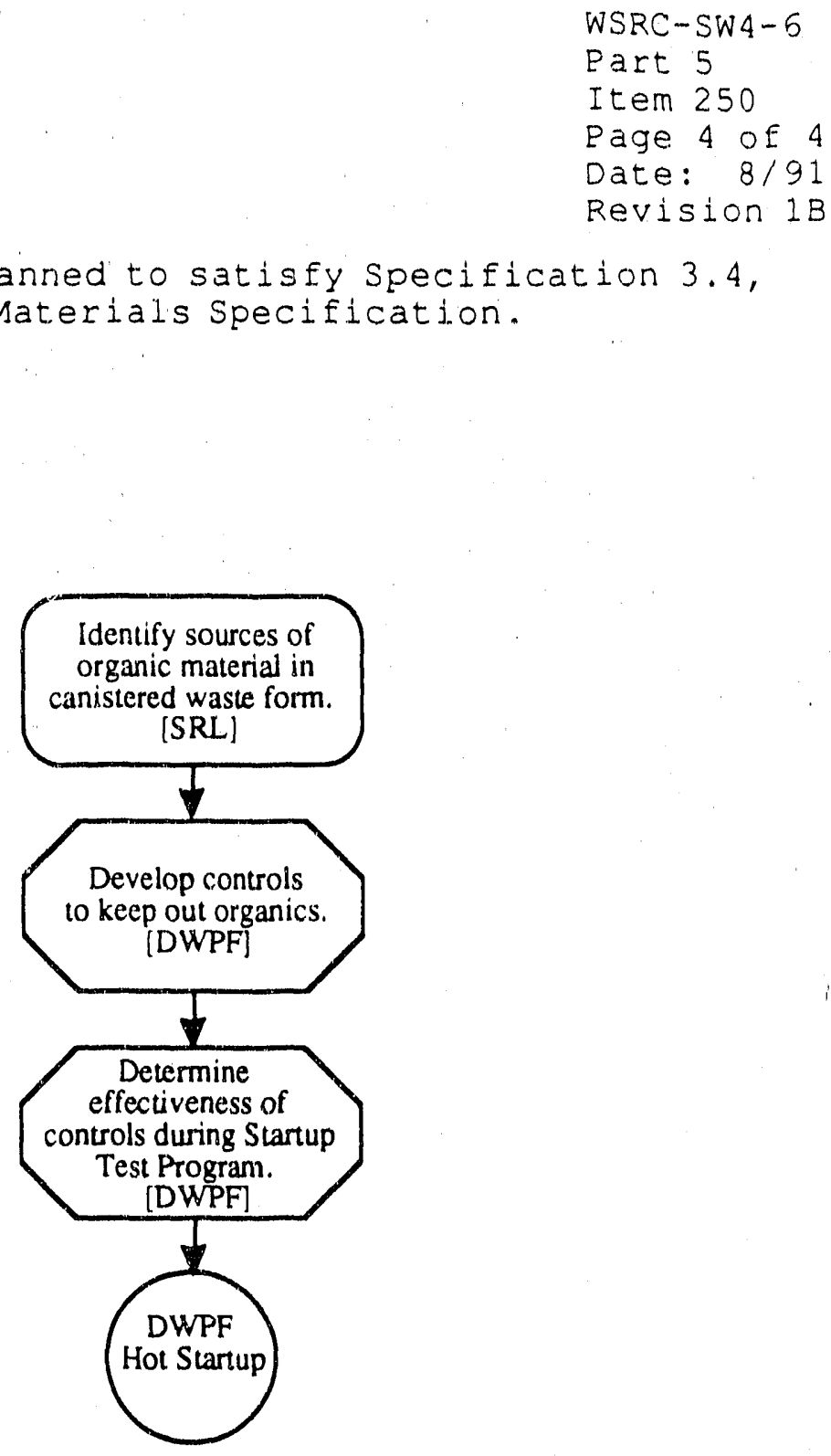
WSRC - SW $4-6$

Part 5

Item 300

Page 1 of 4

Date: $8 / 91$

Revision $1 \mathrm{~B}$

PART TITLE: CANISTERED WASTE FORM SPECIEICATIONS

ITEM TITLE: 3.5 EILL HEIGHT SPECIFICATION

\subsection{FILI HEIGHT SPECIRICATION}

The producer shall fill the canister to a height equivalent to at least 808 of the volume of the empty canister. The producer shall report this height in the production Records and describe the method of compliance in the WCP. Documentation supporting the selected method of compliance shall be provided in the WQR.

\section{Bationale}

In general, the free volume, as measured by the fill height, is to be minimized to minimize the needed repository space.

\section{compliance strategy}

The DWPF canister has a total internal volume of $735 \mathrm{~L}\left(26.0 \mathrm{ft}^{3}\right)$. The DWPE will comply with the specification by filling canisters with approximately $626 \mathrm{~L}$ of glass $\left(22.1 \mathrm{ft}^{3}\right.$, or $165 \mathrm{gall}$ ) to a fill height of $231 \mathrm{~cm}(91 \mathrm{in}$. This corresponds to about $85 \%$ of the available canister volume. The glass level will be monitored by garnma emission and neutron transmission to assure control of the fill level. Glass weight in the canister will also be monitored as an indication of incomplete filling of the canister (e.g., voids).

\section{Implementation}

The tasks planned to satisfy this specification are outlined in Eigure 5.300.1. They are

- Development of methods to control glass level in the canister, primarily by intrinsic gamma emission and neutron transmission.

- Demonstration of the neutron level detection system during the non-radioactive portion of the startup Test Program.

- Demonstration of the gamma level detection system during the transition to radioactive operations. 
WSRC-SW $4-6$

Part 5

Item 300

Page 2 of 4

Date: $8 / 91$

Revision 18

PART TITLE: CANISTERED WASTE FORM SPECIEICATIONS

ITEM TITLE: 3.5 EILL HEIGHT SEECIEICATION

\section{Glass Level centrel Metheds}

Three independent methods will be used to monitor glass level during the canister filling operation in the DWPE melt cell. These are neutron transmission, intrinsic gamma emissions, and the measurement of canister welght. Both neutron transmission and gamma emmision will be used as methods of level control for canisters filled on the pour turntable. Gamma emission will be the primary method of level control. for canisters filled on the drain turnta. b.le. The weight change of canisters on either turntable will be monitored as an indication of incomplete filling.

The neutron transmission method senses the glass level directly, can detect intermediate thicknesses of glass indicative of uneven canister filling, and is independent of waste loading or level of radioactivity. The system is designed to detect the arrival of the glass level at the 40,60 , and 91 (corresponding to $\sim 858$ fill). $\mathrm{BE}_{3}$ counting systems designed to signal the approach and arrival of the glass level are located at each elevation.

The gamma level detection system measures gamma radiation emanating from radioactive isotopes incorporated in the canistered glass. Gamma radiation detectors are inserted in the Melt Cell shield wall. There are seven gamma radiation detectors per turntable to measure the canister glass fill level. The detectors on the pour turntable are located at the following elevations measured from the canister base: 1, 70,90,91, 94, 114, and 124 inches. The detectors on the drain turntable are located at the following elevations measured from the canister base: $1,71,81$, $91,93,114$, and 124. Should canister monitoring requirements change, forty-two collimated sight tubes for gamma level detection are available in the Melt Cell shield wall.

\section{Demonstration of the Neutron and Gamma Level Systems}

During the non-radioactive portion of the Startup Test Program, the neutron level system on the melter pour turntable will be the primary method used to control filling of the canisters. Results of this demonstration will be reported in the Waste Eorm Qualification Report. Since the intrinsic gamma systems rely on the radioactivity in the glass, demonstration of these systems will not 
PART TITLE: CANISTERED WASTE EORM SPECIEICATIONS

ITEM TITLE: 3.5 EILL HEIGHT SPECIEICATION

be performed until initial radioactive operations begin. At that time, the operation of the system on the pour turntable will be compared to that of the neutron system.

\section{Documentation}

The Waste Form Qualification Report will include reports on development of both the gamma and neutron methods of controlling the glass level in a canister during filling. The Waste Form Qualification Report will also contain the results of testing performed during the startup Test Program to determine how well the glass pouring system can be controlled, and to demonstrate both the neutron and gamma level systems.

The Production Record for each canistered waste form will include the fill height in that canistered waste form.

If a particular canistered waste form is not filled to the specified level, the production Record for that canister will clearly indicate this. However, the DWPE proposes to take no further action if this is the only specification violated. The DWEF proposes this disposition based on the following:

- Eree volume is not a safety or waste isolation issue for the repository. Hence, reliability of processing in the DWPE, and compliance with specifications in the WAPS which are related to safety or waste isolation, should take precedence.

- Although it might be possible to fill some underfilled canisters, there will be some cases (especially when the canister is only slightly under-filled) when this cannot be done without risking overfill of the canister, and consequent harm to processing equipment.

- Even in those cases where filling is possible, it could compromise the DWPE's ability to comply with other specifications which are of concern for safety and wast isolation, such as preventing foreign materials from entering the canister, and decontamination. 


$$
\begin{aligned}
& \text { WSRC-5W4- } 6 \\
& \text { Part } 5 \\
& \text { Item } 300 \\
& \text { Page } 4 \text { of } 4 \\
& \text { Date: } 8 / 91 \\
& \text { Revision } 1 \text { B }
\end{aligned}
$$

FIGURE 5.300.1. Tasks planned to satisfy Specification 3.5, Eill Height Specification.

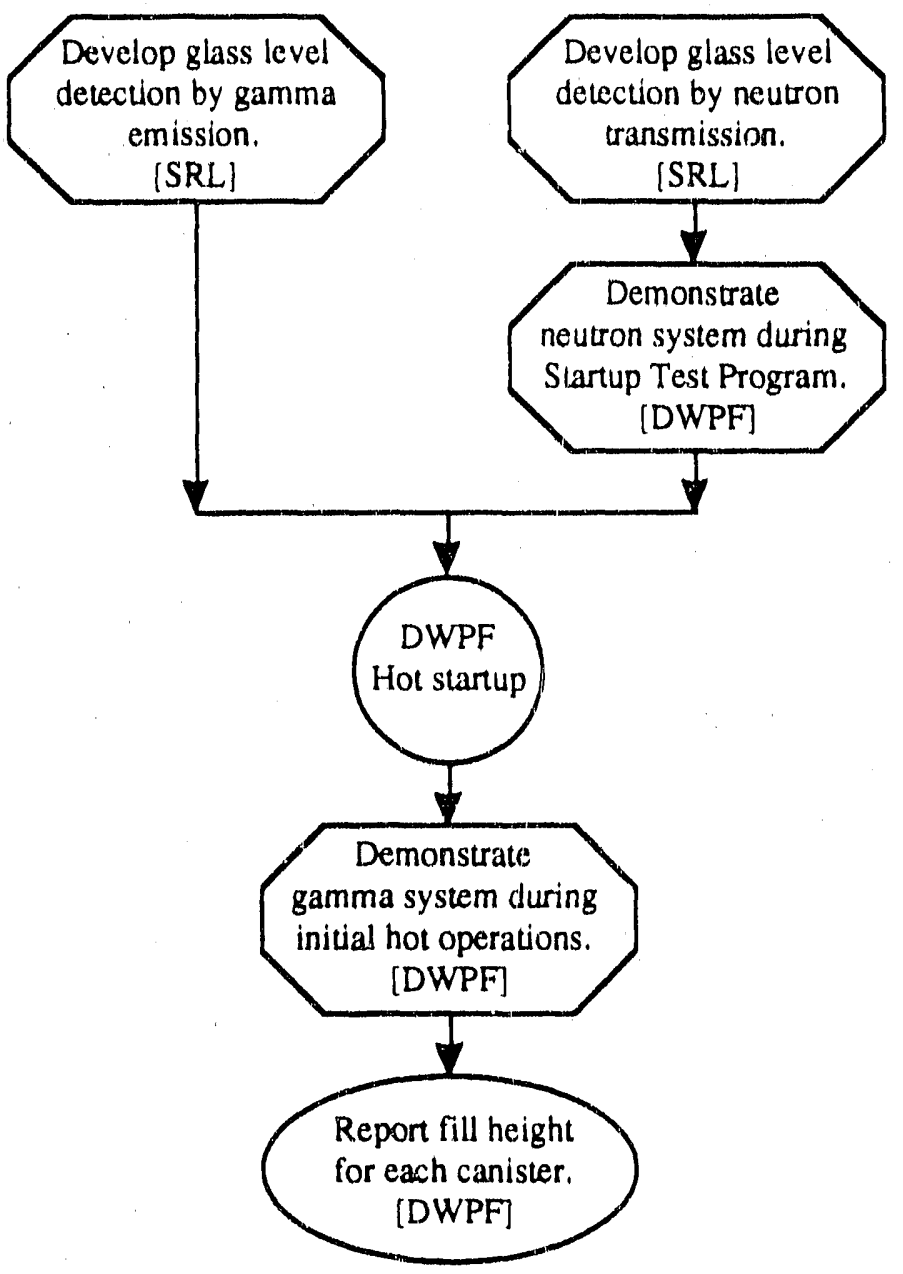


PART TITLE: CANISTERED WASTE FORM SPECIEICATIONS

ITEM TITLE: 3.6 SPECIEICATION EOR REMOVABLE RADIOACTIVE

CONTAMINATION ON EXTERINAL SUREACES

3.6 SPECIFICATION FOR REMOVABLE RADIOACTIVE CONTAMINATION ON EXTERNAL SURFACES

The level of removable radioactive contamination on all external surfaces of each canistered waste form shall not exceed the following limits:

\section{Alpha radiation: $220 \mathrm{dpm} / 100 \mathrm{~cm}^{2}$}

Bota and Gamma radiation: $2200 \mathrm{dpm} / 100 \mathrm{~cm}^{2}$

In addition, the producer shall visually inspect the canistered waste forms and remove visible waste glass on the exterior of the canistered waste form before shipment. The producer shall also provide in the WQR an estimate of the amount of canister material, particularly wall thickness, that is removed during the decontamination and the basis for that estimate. The producer shall describe the method of compliance in the WCP and provide contamination level results in the storage and Shipping Records.

\section{Bationale}

This specification is necessary to protect personnel, prevent uncontrolled spread of contamination during transportation and in repository facilities, minimize noed for remote maintenance of facility equipment, and minimize need for cleanup of contamination during normal operations.

The specification limits chosen are used extensivaly in the nuclear industry practice (e.g., for compliance with 10 CFR 71.87) to indicate surfaces are free of removable contamination.

Compliance strategy

After filling, canistered waste forms will be visually inspected for waste glass on the external surfaces of the canister. Any visible waste glass observed on the exterior of the canistered waste form will be removed by means of a needle gun. The canistered waste form will be decontaminated by frit slurry blasting.1-3 The DWPE will comply with the specification by smear testing the canister in the shipping facility prior to shipment (It must be 
WSRC-SW4-6

Part 5

Item 350

Page 2 of 7

Date: $8 / 91$

Revision $1 B$

PART TITLE: CANISTERED WASTE EORM SPECIEICATIONS

ITEM TITLE: 3.6 SPECIEICATION EOR REMOVABLE RADIOACTIVE CONTAMINATION ON EXTERNAL SUREACES

noted that this faclilty does not yet exist). Additional assurance that the canistered waste forms do not exceed the specified contamination levels will be provided by smear tests of the canister's external surfaces in the DWPE during production.

Implementation

The tasks planned to satisfy this specification are outilned in Eigure 5.350.1. They are

- Development and testing of a method to remove any vistble waste glass from the cantster exterior, before it leaves the vitrification building.

- Development of a method to decontaminate the canistered waste form.

- Determination of the amount of material removed from the canister wall.

- Development of the technical bases for smear procedures in the DWPE, and design of a smearing system in a shipping facility.

- Design and qualification tosting of the shipping facility.

Removal of Vistble Glass

The canistered waste forms, while in the Melt Cell after filling, will be visually inspected for adhering glass. If any adhering glass is detected, it will be removed before the canister is transferred from the Melt Cell to the Canister Decontamination Cell. Use of a needle gun (e.g., Von-ARX needle gun distributed by Marindus Co.) to remove adhering glass from the canister surface has been demonstrated. A remote method of supporting the needle gun and of removing from the canister surface the glass particles generated during operation will be developed, and tested.

Canister Decontamination

Air-injected frit slurry blasting has been shown to be the most 
WSRC $-S W 4-6$

Part 5

Item 350

Page 3 of 7

Date: $8 / 91$

Revision 18

PART TITLE: CANISTERED WASTE FORM SPECIEICATIONS

ITEM TITLE: 3.6 SPECIEICATION FOR REMOVABLE RADIOACTIVE CONTAMINATION ON EXTERNAL SUREACES

efficlent method of canister decontamination investigated.2 It ef fectively cleans the canister external surfaces, and the waste generated is recycled to the vitrification process. In this process, the canister is placed in the DWPF Canister Decontamination Chamber (see Elgure 5.350.2). In this device, a slurry of glass filt suspended in water is pumped to blast nozzles which acceler ate the motion of the frit slurry toward the canister surface by high pressure air. After frit blasting, the canister surface is rinsed with a water Jet, and then air dried. The canister is lifted and rotated during these procedures by a Canister Manipulating Mechanism (CMM). Preliminary process parameters to be used in the DWPE' have been identifled and demonstrated by blasting 26 simulated waste glass canisters using the actual DWPE Canister Decontamination Chamber. This process w111 be tested further during the Startup Test Program (see Appendix 1.200.3).

\section{Metal Removal Durtng Decentamination}

Based on process development work at SRL, a single slurry frlt blasting cycle will remove $70 \mathrm{~g}$ of canister materlal (metal and contaminated oxides), or approximately $2 \mathrm{mg} / \mathrm{cm}^{2}$ of canister surface area (This corresponds to a penetration of $\sim 0.2 \mu \mathrm{m}$.). It has been shown that a conservative estimate of the minimum metal removal required to achieve the specifled level of decontamination is 1 $\mathrm{mg} / \mathrm{cm}^{2}$,

\section{Techntcal Bases for Smearing}

After frit blasting, the canister will be checked for residual contanination. Paper disks $3.18 \mathrm{~cm}(1.25 \mathrm{in})$ in diameter will used to smear the surface of each rotating cantster. Each smear paper contacts an area of $300-600 \mathrm{~cm}^{2}\left(100 \mathrm{in}^{2}\right)$.

The cantster will be transferred to the Weld Test cell for final. closure only after all smear test results are within the specified limits. If any smear exceeds speclfied limits, the canister will be decontaminated again by slurry-blasting until the contamination level is within the specified limits. A confirmatory smear test will also be made in the Weld Test cell prior to transfer to interlm storage in the DWPE's Glass Waste storage Building. 
PART TITLE: CANISTERED WASTE EORM SPECIEICATIONS

ITEM TITLE: 3.6 SPECIEICATION FOR REMOVABLE RADIOACTIVE CONTAMINATION ON EXTERNAL SUREACES

SRL is carrying out a program to provide the technical bases for development of smear test procedures. In this program variables such as the type of pad used for smearing, the amourt of force applied to the pad, the method of application of the force, the area actualiy contacted by the smear pad, the distance the smear pad travels along the canister surface, and the curvature of the can1ster surface are being examined. Based on the results, DWPE Will develop smear testing procedures for both the vitrification buliding and the shipping faclilty.

\section{Candster Shipotng Facility}

Sometime in the future, a canister shipplng faclilty will be designed and bullt. The technical bases for smearing described above, as well as the experlence with the smear testing systems in the DWEE, w1l1 be used as design input for the faclitty. once built, it is anticlpated that a qualification program will be carried out, to ensure that the shipping Facility's procedures and equipment will satisfy the specification.

\section{Decumentation}

The Waste Form Qualification Report (WQR) will include a report on the decontamination method, the amount of material removed during decontamination, and the technique for removing visible waste glass from the canister exterior. The WQR will also include the results of the program to devolop the technical bases for the smear test procedures.

The DWPE' will report, in the Shipping and storage Records, all smear test results for each canister.

\section{Beferences}

1. W. N. Rankin, "Decontamination Processes for Waste Glass Canisters," Nuclear Technology, 59, 314-20 (1982).

2. C. R. Ward, Selection and Dovelopment of Air-Injectad rrit Slurxy Blasting for Decontamination of DWP Canisters, USDOE Report DP-1692, E. I. Du Pont de Nemours, Inc., Savannah River Laboratory, Alken, SC 29808 (1984). 
WSRC - SWA - is

Part 5

Item 350

Page 5 of 7

Date: $8 / 91$

Revision $1 \mathrm{~B}$

PART TITLE: CANISTERED WASTE EORM SPECIEICATIONS

ITEM TITLEI 3.6 SPECIEICATION EOR REMOVABLE RADIOACTIVE CONTAMINATION ON EXTERNAL SUREACES

3. A. H. Harris and C. R. Ward, Dovelopment and Demonstration of the DWR Canister Decontamination Process Using Jrit Slurry Blasting, USDOE Report DP-MS-86-128, E. I. Du Pont de Nemours, Inc., Savannah River Laboratory, Aiken, SC 29808 (1.986). 


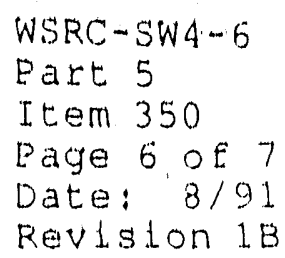

EIGURE 5.350.1 Tasks planned to satisfy Specifleation 3.6, Specliflcation for Removable Radioactive Contamination on External Surfaces.

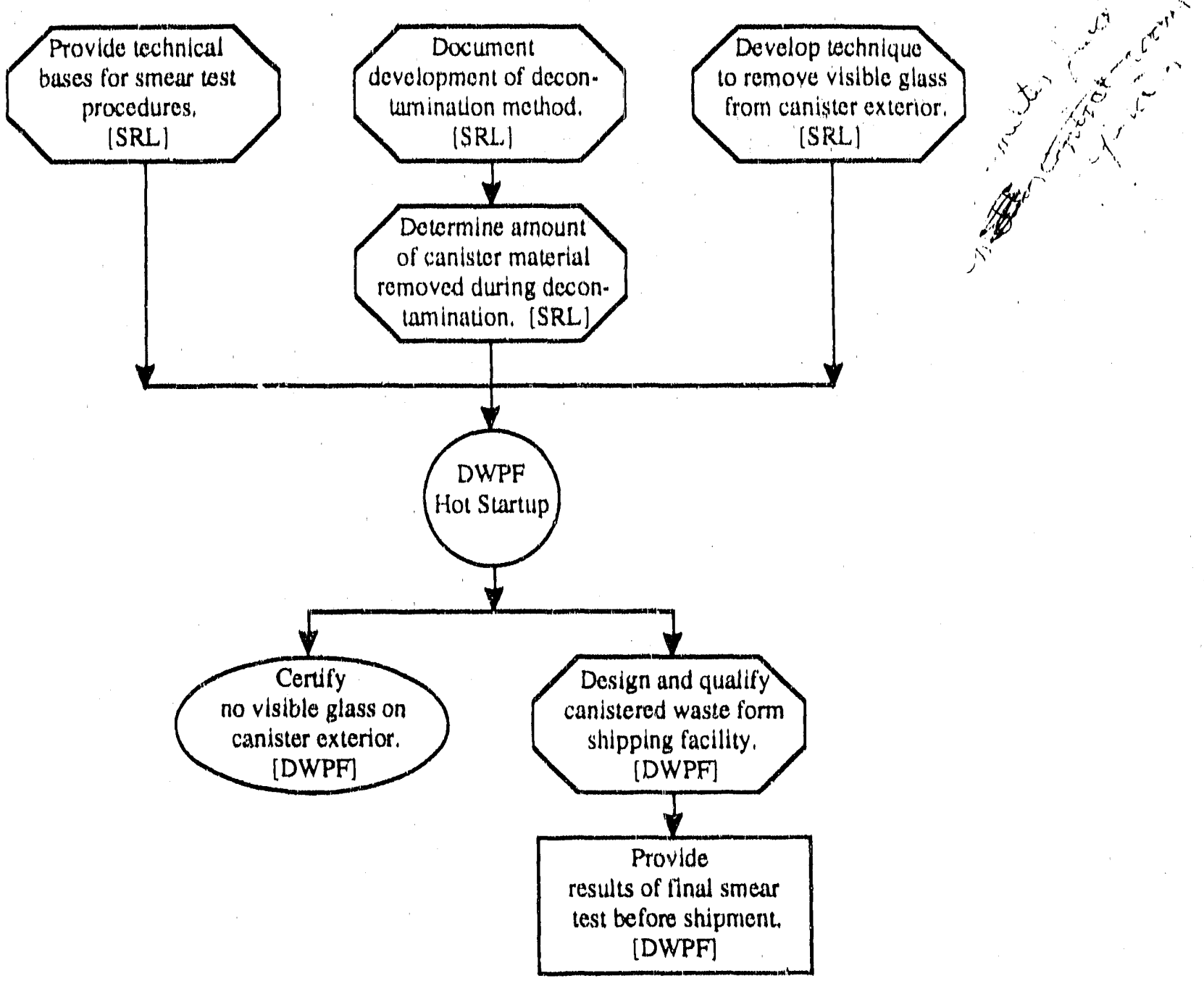


WSRC-SW4-6

Part 5

ltem 350

Eage $\%$ of 7

Date: $8 / 91$

Revision $1 \mathrm{~B}$

EIGURE 5.350.2 DWPE Canister Decontamination Chamber.

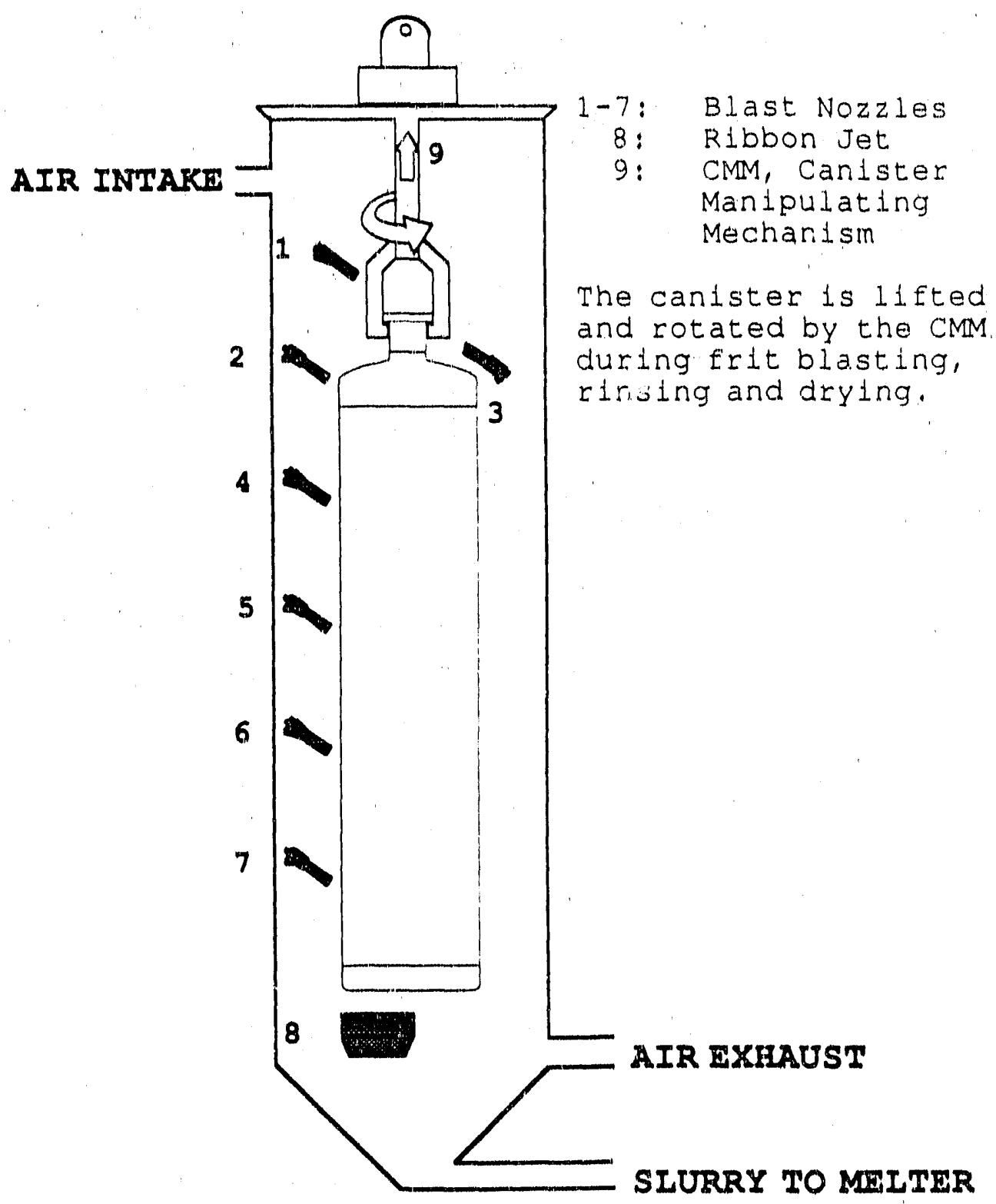


PART TITLE: CANISTERED WASTE EORM SPECIEICATIONS

ITEM TITLE: 3.7 .1 HEAT GENERATION PROJECTIONS

\subsection{HEAT GENERATION SPECIEICATION}

The canistered waste form total heat qeneration rate shall not exceed 1500 watts per canister indexed to the year 2025.

\subsubsection{Heat Genecation Rrejections}

The producer shall document in the WQR the expected thermal output of canistered waste forms and the range of expected variation in thermal output for each waste type during the life of the production facility. The method to ba used for demonstrating compliance shall be described by the producer in the WCP. Projections for compositions not available for reporting in the initial weR shall be included in an addendum to thi WQR.

\section{Bationale}

A heat generation rate limit ensures that the temporatures reached in other disposal package components or the host rock do not significantly reduce theix performance capabilities.

Repository designers need heat generation rate values to ensure that repository thermal load limits are not violated. The value of 1500 watts was chosen as an expected upper bound for production for any HLW glass production facility.

Information on the range of expected variation in heat generation rates is necessary to allow assessuent of variation in repository performance and to optimize repository emplacement design.

\section{Cempliance strategy}

The expected thermal output and the range of expected variations for the canistered waste forms will be calculated based on the radionuclide inventory projections described in Part 3, Item 300.

\section{Implementation}

As shown in Eigure 5.400 .1 , this specification will be satisfied $b_{y}$

- Providing the radionuc? ide inventory projections as described 
WSRC-SW $4-6$

Part 5

Item 400

Page 2 of 4

Date: $8 / 91$

Revision $1 \mathrm{~B}$

PART TITLE: CANISTERED WASTE EORM SPECIEICATIONS

ITEM TITLE: 3.7 .1 HEAT GENERATION PROJECTIONS

in Part 3, Item 300 .

- Converting the radionuclide inventory projections into projections of heat generation rates for each waste type. This will be done by multiplying the amount of each radionuclide by its specific thermal output, as calculated from standard values.

- Estimating the range of values for each waste type by bounding calculations.

\section{Calculation of Heat Generation Rates}

Eor each of the waste types identified in Part 3, Item 300, the heat generation rate will be calculated from the radionuclide inventory of the glass, using standard values of the thermal output per unit activity for each radionuclide. The radionuclides which will be included in performing this calculation will be all of those radionuclides to be reported to the repository as part of the radionuclide inventory* (see Part 3, Item 400), and any other short-lived radionuclides in the Design-Basis waste which significantly contribute to the heat generation rate. Preliminary calculations indicate that the latter will be of importance only for waste which is 10 years old or less.

\section{Estimation of Ranges of Heat Generation Bates}

The range of the heat generation rates for each waste type will be provided through simple bounding calculations. The lower bound for each waste type is assumed to be glass which contains no radionuclides, either due to melter startup (when actual waste glass is displacing simulated waste glass), or due to flushing operations (e.g., when a melter is about to be taken out of service). The upper bound will be estimated by assuming a 90 fill of a glass which contains the maximum amount of waste which will produce an acceptable glass (based on the algorithms described in Part 3, Item 500).

* Those with half-lives greater than 10 years, and which constitute at least 0.01 of the radionuclide inventory at any time up to 1100 years after production. 
WSRC - SW $4-6$

Part. 5

Item 400

Page 3 of 4

Date: $8 / 31$

।

Revision $1 \mathrm{~B}$

PART TITLE: CANISTERED WASTE FORM SPECIEICATIONS

ITEM TITLE: 3.7.1 HEAT GENERATION PROJECTIONS

Recumentation

The Waste Form Qualification Report will include a report on the expected thermal output and the range of expected variations for the canistered waste forms. 


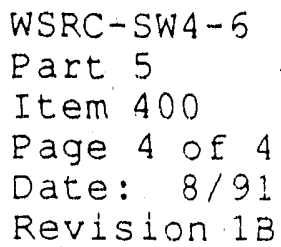

EIGURE 5.400.1 Task planned to satisfy Specification 3.7.1, Heat Generation Projections.

\section{Estimate} radionuclide inventory (see Part 3, item 300) [SRL]

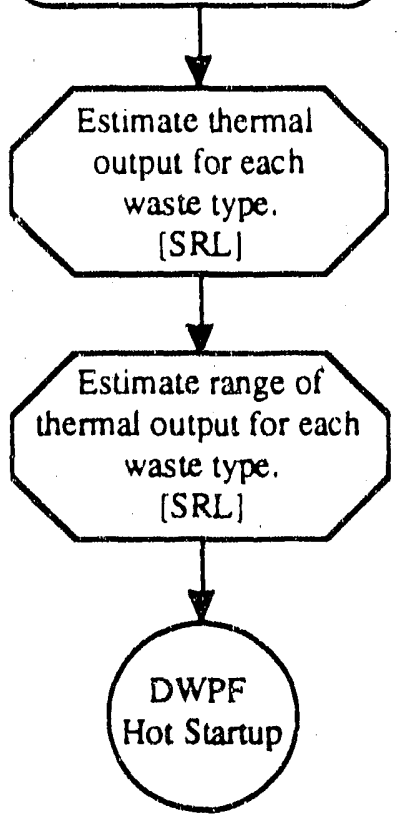


WSRC - SW $4-6$

Part 5

Item 450

Page 1 of 4

Date: $7 / 91$

Revision $1 \mathrm{~A}$

PART TITLE: CANISTERED WASTE FORM SPECIEICATIONS

ITEM TITLE: 3.7 .2 HEAT GENERATION DURING PRODUCTION

\subsection{GEAT GENERATION SPECIFICATION}

\section{7 .2 Heat Generation During Production}

The producer shall report in the Production Records the heat generation rate for each canistered waste form at time of production. The estimated error of the heat generation rates shall be provided in the WQR. The producer shall describe the plan for compliance in the WCP.

\section{Bationale}

A heat generation rate limit ensures that the temperatures reached in other disposal package components or the host rock do not significantly reduce their performance capabilities.

Repository designers need heat generation rate values to ensure that repository thermal load limits are not violated. The value of 1500 watts was chosen as an expected upper bound for production for any HLW glass production facility.

Information on the range of expected variation in heat generation rates is necessary to allow assessment of variation in repository performance and to optimizo repository emplacement design.

\section{compliance strategy}

The heat generation rate of each canistered waste form will be calculated based on the radionuclide inventory described in part 3. Item 400, augmented by analytical results for short-lived radionuclides (measured for process safety reasons). Thus, in the Production Records, the DWPE will report the average heat generation rate, and the standard deviation, for all the canisters produced from a given macro-batch. If, at time of proposed shipment, a canistered waste form has a heat generation rate greater than 1500 watts, the canistered waste form will be identified as a nonconforming item, and dispositioned as outlined in Part 6, Item 800 .

\section{Implementation}

The tasks planned to satisfy this specification are outlined in 


\section{PART TITLE: CANISTERED WASTE FORM SPECIEICATIONS \\ ITEM TITLE: 3.7 .2 HEAT GENERATION DURING PRODUCTION}

Eigure 5.450.1. They are to calculate the heat generation rate from the radionuclide inventory, and to estimate the error in the method of calculation.

\section{Calculation of Heat Generation Bate}

The heat generation rate will be calculated from the radionuclide inventory of the glass, using standard values of the thermal output per unit activity for each radionuclide. The radionuclides which will be included in performing this calculation will be all of those radionuclides to be reported to the repository as part of the radionuclide inventory* (see Part 3, Item 400), and any other radionuclides analyzed for process safety purposes in the DWPE (e.g. Pr-144, Eu-154, or Eu-155). Preliminary calculations indicate that the latter will be of importance only for waste which is 10 years old or less.

Because the radionuclide inventory is reported on a macro-batch basis, the heat generation rate will also be reported in that manner. Each radionuclide inventory value estimated from process batches for a given macro-batch will be used to generate a heat generation rate. These heat generation rates will then be averaged, and a standard deviation calculated. This average heat generation rate, and its standard deviation will then be reported for each canister of the macro-batch.

If the heat generation rate exceeds 1500 watts (taking into account the uncertainty in the calculated value) at time of shipment of the canister from the DWPE, the canister will be identified as a nonconforming item, and then dispositioned according to the procedure outlined in Part 6. Item 800 .

Estimates of Error

Preliminary calculations have already been performed for the Design-Basis glass. At time of production, the heat generation rate of the glass is calculated to be 731 watts/canistered waste form. The dominant source of error in the calculation is the radionu*Those with half-lives greater than 10 years, and which constitute at least 0.018 of the radionuclide inventory at any time up to 1100 years after production. 
PART TITLE: CANISTERED WASTE EORM SPECIFICATIONS

ITEM TITLE: 3.7 .2 HEAT GENERATION DURING PRODUCTION

clide inventory. Using the present estimates of uncertainties in the radionuclide inventory in Part 3, Item 400 , indicates that the calculated heat generation rate will be within $10 \%$ of the actual value (There will be a slight bias in the reported values; less than about 15 watts for the worst casel. Calorimetric experiments will also be performed to better estimate the error in the calculation.

\section{Documentation}

The Waste Eorm Qualification Report will include a description of the heat generation rate calculation, the results of tests to determine the error in the reported values, and an estimation of the error.

The production Record for each canistered waste form will include the heat generation rate as calculated from the radionuclide inventory of the glass. 
WSRC $-5 W 4-6$

Part 5

It.em 450

Page 4 of 4

Date: $7 / 91$

Revision $1 \mathrm{~A}$

EIGURE 5.450.1 Tasks planned to satisfy Specification 3.7.2, Heat Generation During Production.

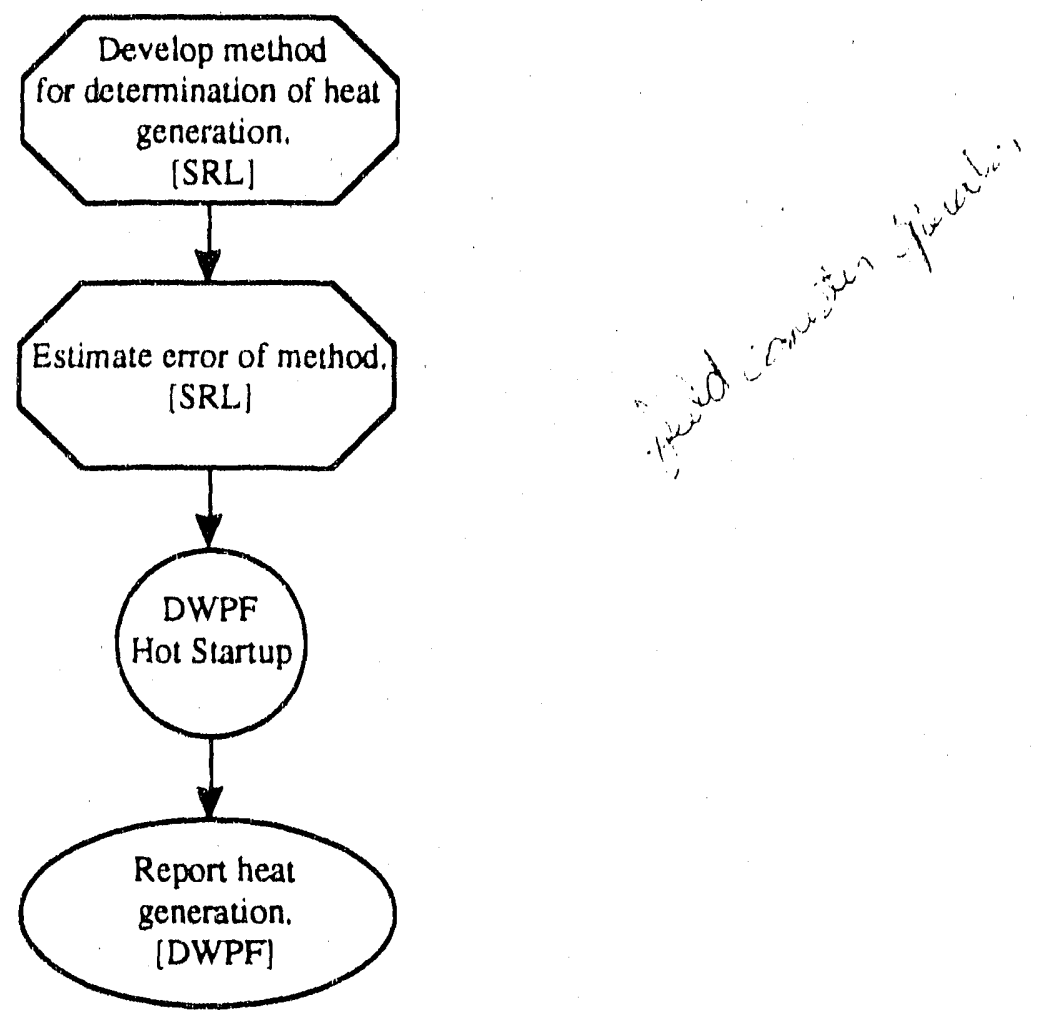


PART TITLE: CANISTERED WASTE EORM SPECIEICATIONS

ITEM TITLE: 3.8 .1 PROJECTIONS OE MAXIMUM DOSE RATES

\subsection{SRECIFICATION FOR MAXIMUM DOSE RATES}

The canistered waste form shall not exceed a maximum surface gamma dose rate of $10^{+5}$ rem/hr and a maximum neutron dose rate of 10 $\mathrm{rem} / \mathrm{hr}$, indexed to the year 2025 .

\subsubsection{Projections of Maximum Dose Rates}

The producer shall specify in the WQR the expected values and the range of expected variation for both gamma and neutxon dose rates. The producer shall describe the method for demonstrating compliance in the WCP.

\section{Bationalo}

The repository project needs the maximum gamma and neutron dose rates in order to design shielding for the receipt and handling facilities. This information is also needed by tha shipper to provide adequate transportation casks. The values of $10^{+5} \mathrm{rem} / \mathrm{hr}$ for maximum gamma dose rate and $10 \mathrm{rem} / \mathrm{hr}$ for maximum neutron dose rate provide a reasonable basis for repository design and operation and are judged to be sufficiently above the expected dose rates for HLW glass waste forms to provide reasonable flexibility for noxmal operations.

Compliance Strategy

The expected dose rates and the range of expected variation will be calculated based on the radionuclide inventory projections described in Part 3, Itern 300.

Implementation

As shown in Eigure 5.500 .1 , this specification will be satisfied by

- Providing the radionuclide inventory projections as described in Part 3, Item 300 .

- Converting the radionuclide inventory projections into projections of dose rates for each waste type. 
WSRC $-5 W 4-6$

Part 5

I.tem 500

Page 2 of 1

Date: $8 / 91$

Revision $1 \mathrm{~B}$

PART TITLE: CANISTERED WASTE EORM SPECIEICATIONS

ITEM TITLE: 3.8 .1 PROJECTIONS OE MAXIMUM DOSE RATES

- Estimating the range of values for each waste type by bounding calculations.

\section{Calculation of Dese Rates}

The values requtred by this spectfication will be determined by converting the radionuclide inventory projections described in Part 3, Item 300, into corresponding projectlons of neutron and gamma dose rates. This will be done by multiplying the amount of each radionuclide by its dose rate per curle. Self-shielding and shielding by the canister will also be taken into account.

Preliminary estimates of the maximum dose rates of DWPF canistered waste forms have already been made. These have been calculated from the composition and radionuclide inventory of the DesignBasis waste glass). These calculations are summarized in Table 5.500 .1 .

\section{Estimation of Ranges of Dese Rates}

The range of the dose rates for each waste type w111 be provided through simple bounding calculations. The lower bound will be estimated by assuming only 80 of fll of a glass which contains the minimum amount of waste which will produce an acceptable glass (based on the algorlthms described in Part 3, Item 500). The upper bound will be estimated by assuming a 90 fill of a glass which contains the maximum amount of waste which will produce an acceptable glass.

\section{Decumentation}

The Waste Eorm Qualification Report will include a report on the projections of gamma and neutron dose rates, and their expected varlations. Results of tests of the calculational methods will also be reported, including the experimental vertfication of the SRS neutron dose rate calculations. 


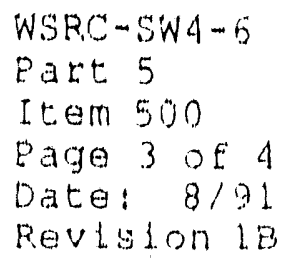

TABLE 5.500.1 Calculated maxtmum gamma and neutron dose rates $2:$ DWeE canistered waste forms (based on Design-Bastis Glass).

Distance (Et)

Surface

1

3

5

10

20

30

50

75

100
Gamma $(R / h x)$

5570

2190

900

470

160

44

20

7

3

2
Noutrons (mrem/hrL

420.

97.

42.

23.

7.5

2.5

1.0

0.5

$-, \cdots$

$-.-$
Tetad (B/hrL

5370

2190

900

470

160

44

20

7

3

2 


$$
\begin{aligned}
& \text { WSRC-SWA-6 } \\
& \text { Part } 5 \\
& \text { teem } 500 \\
& \text { Page } 4 \text { oE } 4 \\
& \text { Date B } 3: 91 \\
& \text { Reviston } 1 B
\end{aligned}
$$

EIGURE 5.500.1, Tasks planmed to satisfy spectitiation 3.8.1, Profections of Maxlmum Dose Rates.

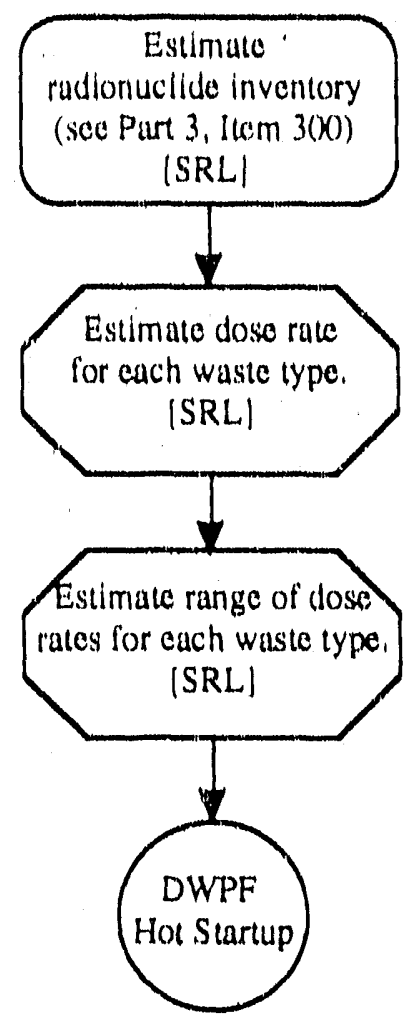


WSRC-SW4-6

Part 5

Item 550

Page 1 of 3

Date: $8 / 91$

Reviston $1 . B$

PAR'T TITLE: CANISTERED WASTE EORM SPECIEICATIONS

ITEM TITLE， 3.8.2. MAXIMUM DOSE RATES DURING PRODUCTION

\subsection{SPECIFICATION FOR MAXIMUM DOSE RATES}

\section{8 .2 Maximum pose Bater at Thme of Shipment}

The producer shall provide in the storage and Shipping Records the estlmated values for both gamma and seutron dose rates for the canistered waste forms. The producer shall describe the method of compliance in the WISP.

\section{Ratitopalia}

The repository project needs the maximum gamma and neutron dose rates in order to design shielding for the recalpt and handiing facilitias. This information is also noeded by the shipper to provide adequate transportation casks. The values of $10^{+5} \mathrm{rem} / \mathrm{hr}$ for maximum gamma dose rate and $10 \mathrm{rem} / \mathrm{hr}$ for maximum neutron dose rate provide a reasonable basis for repository design and operation and are judged to be suffiolentily above the expected dose rates for HIW glass waste forms to provide reasonable flexibility for normal operations.

complidance Strategy

The DWPE will comply with the specification by measuring the dose rates from canistered waste forms in the shipplng faclitty prior to shipment (It must be noted that this facility does not yet ex1st). Additional. assurance that the canistered waste forms do not exceed the specified dose rates wlil be provided by dose rate measurements in the DWPE'

Implementation

The tasks planned to satisfy this spectflcation are outilned in Elgure 5.350.1. They are

- Development of methods to measure the neutron and gamma dose rates of the canistered waste form, before 1 t. leaves the vitrification bullding.

- Design, construction, and qualification testing of the shipping factitity. 
PART TITLE: CANISTERED WASTE EORM SPECIEICATIONS

ITEM TITLE: 3.8 .2 MAXIMUM DOSE RATES DURING PRODUCTION

Measurement of Nieut ron and Gamma Dose Rates

During production, the gamma and neutron dose rates for the canisin tered waste forms w111 be measured Just before the canistered waste form is transferred from the vitrification bullding to the Glass Waste Storage Bullding. Standard technlques and instruments will be adapted to this task.

As part of the transition to radioactive operation, these instruments will be tested in the DWPE. The technology which will be employed within the DWEE w111 be described in the Waste Form Qualification Report, as well as the results of the qualification testing. this will establish the existence of technology necessary for the Shipping Facility.

Desigh, and Quadification. Testing of the Shidotng Eacility

Sometime in the future, a canlster shipping facility will be designed and bullt. The instruments used in the DWPF to measure neutron and gamma dose rates, as well as the operating experience with those instruments, w1.11 be used as design input for the facility. Once bullt, it is anticlpated that a qualification program will be carried out, to ensure that the procedures and equipment will satisfy the specification.

\section{Decumentation}

The Waste Form Qualification Report will include a description of the instruments used to measure the gamma and neutron dose rates in the DWPE, and the results of qualification testing during the transition to radioactive operations.

The Shipping and Storage Record for each cantstered waste form will include the gamma and neutron dose rates of the canistered waste form as determined in the DWPE shipping facility.

If the calculated dose rates exceed $10^{5} \mathrm{R} / \mathrm{hr}$ surface gamma dose rate, or $10 \mathrm{rem} / \mathrm{hr}$ neutron close rate, then the canlstered waste form will be ldentifled as a nonconforming ltem, and dispositioned according to the procedure outilned in Part 6, Item 300 . 


$$
\begin{aligned}
& \text { WSRC-SW4-6 } \\
& \text { Part } 5 \\
& \text { Item } 550 \\
& \text { Page } 3 \text { of } 3 \\
& \text { Date: } 8 / 91 \\
& \text { Revision } 1 \text { B }
\end{aligned}
$$

FIGURE 5.550.1 Tasks planned to satisiEy Specification 3.8.2, Maximum Dose Rates during Production.

Develop methods 10 determine dose ratis. [DWPF]

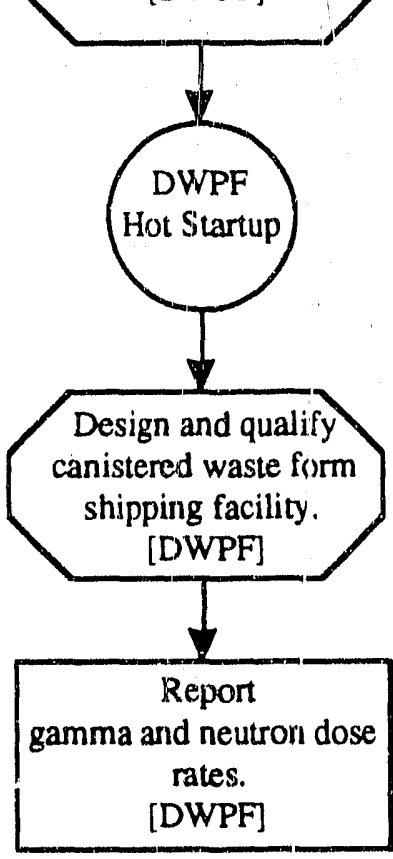


PART TITLE: CANISTERED WASTE FORM SPECIFICATIONS

ITEM TITLE: 3.9 CHEMICAL COMPATIBILITY SPECIFICATION

\subsection{CHEMICAI COMPATIBILITY SPECIEICATION}

The contents of the canistered waste form shall not lead to internal corrosion of the canister such that there will be an adverse effect on normal handling during storage, and on an abnormal occurrence such as a canistex drop accident. The producer shall describe the method of demonstrating compliance in the WCP. Corrosion, chemical interactions, and any reaction products generated within the canistered waste forms after exposure to temperatures up to the glass transition temperature shall be discussed in the WQR.

\section{Bationale}

The specification is required to assure that the canister can be safely handled during storage, transportation, and repository operations, and to provide needed data for assessment of long-term performance of the waste package components.

The regulatory requirements on the waste package as outlined in 10 CFR 60.135 (b) (1) state that "The waste package shall not contain... chemically reactive materials in an amount that could compromise the ability of the underground facility to contribute to waste isolation or the ability of the geologic repository to satisfy the performance objectives."

\section{compliance strategy}

The extent of chemical reactivity among the borosilicate waste glass, the canister, the gas in the void space, and the volatiles from the waste glass will be determined from either available technical literature or new experimental evidence, as necessary. Long-term testing indicates that the canistered waste form will not experience significant internal corrosion of the canister, as long as liquid water is excluded. Controls are being implemented to prevent ilquid water from entering the canistered waste form, as described in Part 5, Item 100.

\section{Implementation}

The tasks planned to satisfy this specification are outlined in Figure 5.600.1. These include: 
WSRC-SW 4- 6

Part 5

Item 600

Page 2 of 6

Date: $7 / 91$

Revision $1 \mathrm{~A}$

PART TITLE: CANISIERED WASTE FORM SEECIEICATIONS

\section{ITEM TITLE: 3.9 CHEMICAL COMPATIBILITY SPECIEICATION}

- Identification of all of the materials expected to be present within the canistered waste form.

- Review of the literature as to the extent of reactions between the contents of the canister and the canister itself. Preliminary indications are that the exclusion of liquid water from the canistered waste form will be necessary to avoid internal corrosion.

- Development of controls to exclude liquid water from the canistered waste forms, as described in Part 5, Item 100.

- If requilred by the literature review, an experimental evaluation of the extent of reactions between the contents of the canister and the canister itself.

- Determination of the effects of exposure of the canistered waste form to temperatures up to the glass transition temperature, $\mathrm{T}_{\mathrm{g}}$ on the compatibility of the canister and its contents.

Materials present in the Canistered Waste Eorm

Borosilicate waste glass will not be the only material inside canistered waste forms from the DWPE. In particular, salts (primarily borates, halides, and sulfates) will volatilize from the stream of molten glass as it pours into the canister, and condense on the cooler canister wall. Experiments will be performed to identify all materials, besides waste glass, which will be present in the canistered waste form. These experiments will include examination of prototypic canisters filled under simulated production conditions and during the startup Test Program, and sampling and analysis of any non-vitreous materials found.

Corrosion Reactions between the canister and its contents

The available literature is being reviewed to determine what is already known concerning the chemical reactivity of the borosilicate waste glass, any void space gases, and waste glass volatiles, with the stainless steel canister. This information will be supplemented with new experimental evidence to further investigate the chemical compatibility of the canister and its contents. 
WSRC - SW $4-6$

Part 5

Item 600

Page 3 of 6

Date: $7 / 91$

Revision $1 \mathrm{~A}$

\section{PAR'T TITE: CANISTERED WASTE FORM SPECIEICATIONS \\ ITEM TITLE: 3.9 CHEMICAL COMPATIBILITY SPECIEICATION}

Studies investigating the effects of the internal canister environment on canister corrosion have concluded that no significant corrosion of the DWPF canister will occur during interim storage provided liquid water is prevented from entering the canister. Dew point calculations supported by dew point measurements show that even in the most humid conditions expected during canister sealing, vapor phase water will not condense inside the canister as it. cools. The most humid credible conditions will produce a dew point of $31^{\circ} \mathrm{C}$; however a reference DWPE canister will maintain a surface temperature of $35^{\circ} \mathrm{C}$ due to waste heat loading, preventing condensation of the small amount of trapped water vapor.

Existing experimental information indicates that, as long as water has been excluded from the canistered waste form, DWPF processing will not significantly affect the ability of the $304 I_{1}$ stainless steel canister to act as a container for the waste glass during interim storage at SRS, during transport to the repository, or during the retrievability period. 1

Tests have been performed in which sensitized $304 \mathrm{I}$ coupons were exposed to molten glass for durations of up to 10,000 hours. Figure 5.600 .2 shows the test design. After testing, the metal specimens were mounted in resin, ground and polished, and examined microscopically. The depth of intergranular penetration was determined, as well as the amount of material loss. It was concluded that the glass did not significantly interact with the $304 \mathrm{~L}$. Material penetration and loss rates were less than 3 of the maximum permissible rates (the maximum permissible rates are based on canister integrity during interim storage at SRS and the retrievability period at a repository (assumed to be 100 years)).

Stress corrosion of the canister material during transportation and handling will not be a hazard, as long as a halide/liquid mixture does not contact the canister surface (a very unlikely scenario).

If the literature review is inconclusive, an experimental program will be undertaken to better establish the extent of reaction between the canister and its contents. The nature of this program, if needed, will be based on the results of the review. 
WSRC-SW4-6

Part 5

Item 600

Page 4 of 6

Date: $7 / 91$

Revision $1 \mathrm{~A}$

PART TITLE: CANISTERED WASTE EORM SPECIEICATIONS

ITEM TITLE: $\quad 3.9$ CHEMICAL COMPATIBILITY SPECIEICATION

Development of controls to Exclude Liguid Water

In order to prevent internal canister corrosion, it is necessary to exclude 1 iquid water from the canistered waste form. Administrative controls and canister closure techniques will be used to prevent the introduction of liquid water into the canistered waste form, as described in Part 5, Item 100.

\section{Effects of Exposure to $I_{g}$}

Simulated canistered waste forms (nonradioactive samples containing all materials expected to be present in actual DWPE products - including water vapor) will be exposed to temperatures up to the glass transition temperature, $T_{g}$. After the canistered waste form is exposed to $\mathrm{T}_{\mathrm{g}}$, any corrosion or reaction products $\mathrm{w} 11 \mathrm{l}$ be identified, and the extent of any reactions quantified.

Decumentation

The Waste Form Qualification Report will include a report on the extent of corrosiveness and chemical reactivity among the borosilicate waste glass, the canister, and any other materials which may be present within the sealed canister. The WQR will also include a report on the controls to be used to keep liquid water out of the canistered waste form.

\section{Beferences}

1. W. N. Rankin, Compatibility Testing of Vitrified Waste rorms, USDOE Report DP-MS-77-115, E. I. du Pont de Nemours \& Company, Inc., Savannah River Laboratory, Aiken, SC (1978). 
WSRC-SW $4-6$

Part 5

Item 600

Page 5 of 6

Date: 7/91

Revision $1 \mathrm{~A}$

FIGURE 5.600.1 $3 \mathrm{k} / \mathrm{s}$ planned to satisfy specification 3.9 , Cherical Compatibility Specification.

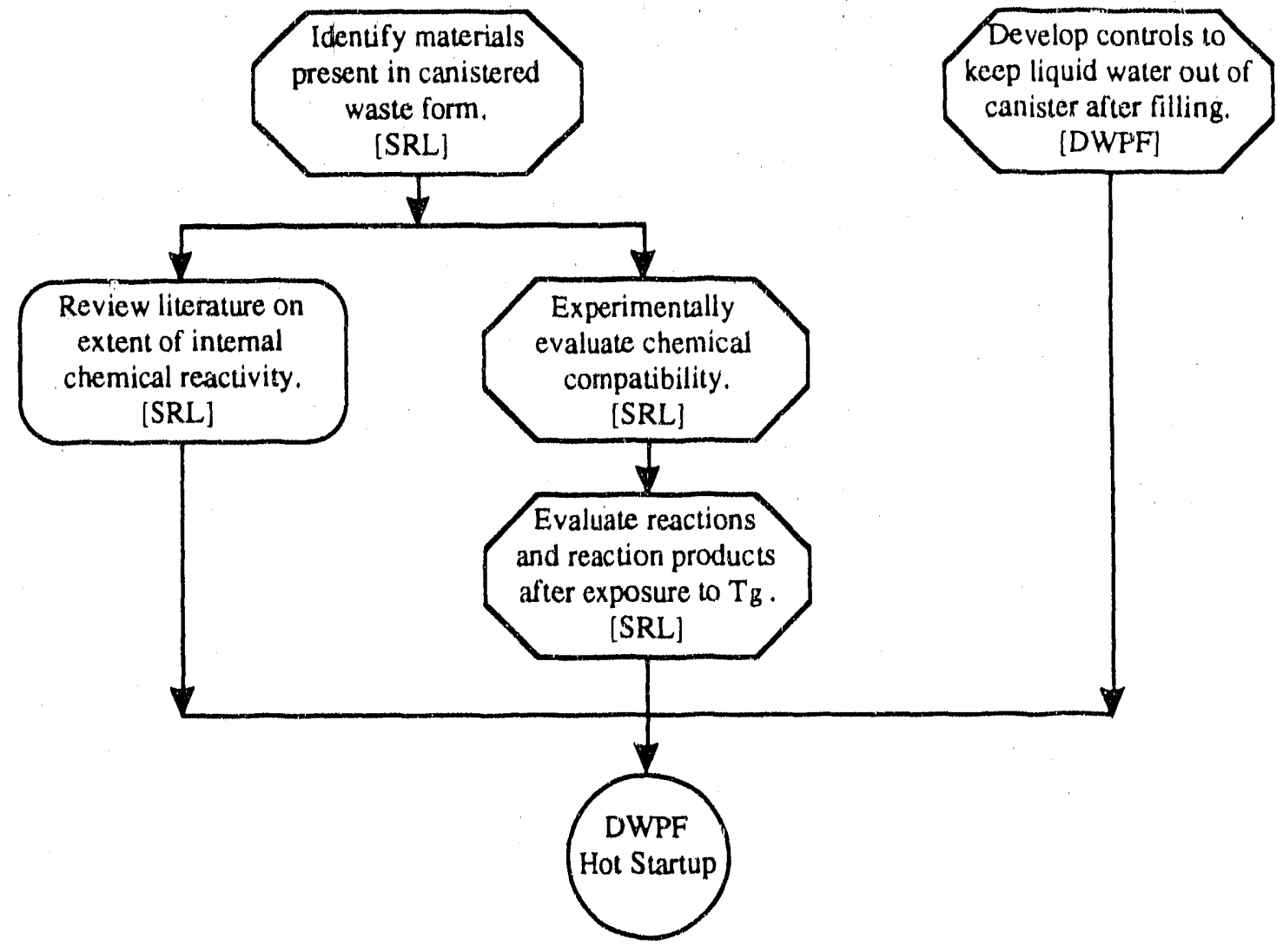


WSRC- - SW 4- 6

Part 5

Item 600

Page 6 of 6

Date: $7 / 91$

Revision $1 \mathrm{~A}$

EIGURE 5.600.2 Experimental design of long-term corrosion tests.

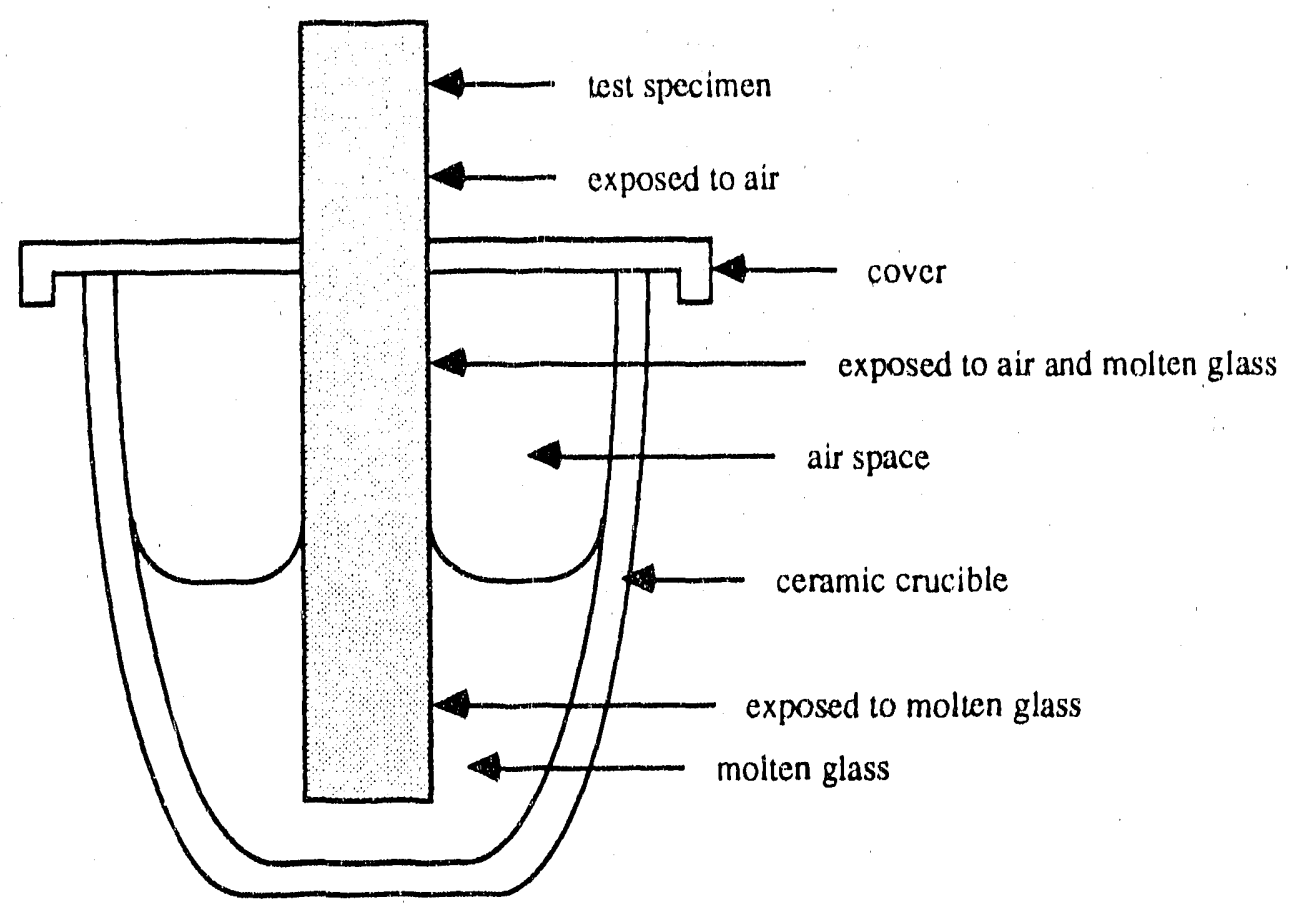


PART TITLE: CANISTERED WASTE EORM SPECIEICATIONS

ITEM TITLE: 3.10 SUBCRITICALITY SPECIEICATION

\subsection{SUBCRITICALITY SPECIEICATION}

The producer shall ensure that the canistered waste form will remain subcritical under all credible conditions likely to be encountered at the producer's site, including the proposed storage array. The calculated effective neutron multiplication factor,

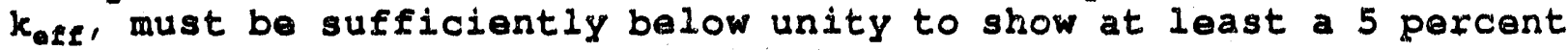
margin, after allowance for bias in the method of calculation and the uncertainty in the experiments used to validate the mathod of calculation. The producer shall describe the method of demonstrating compliance in the WCP and provide supporting documentation in the WQR. The WQR shall also include sufficient information on the nuclear characteristics, such as fissile density, of the canistered waste form to enable the repository project to confirm subcriticality under repository storage and disposal conditions.

\section{Rationale}

The regulatory requirements as outlined in 10 CFR 60.131 (b) (7) state that, "The calculated effective multiplication factor ( $\left.k_{e f f}\right)$ must be sufficiently below unity, to show at least a 5 percent margin, after allowance for the bias in the method of calculation and the uncertainty in the experiments used to evaluate the method of calculation."

\section{Compliance strategy}

The DWPE will comply with the specification by performing bounding calculations to show that the effective multipiication factor for a canistered waste form will be much less than 1 .

\section{Implementation}

The tasks sufficient to satisfy this specification are outlined in Eigure 5.650.1. They include

- Development of the radionuclide inventory projections, as described in Part 3, Item 300.

- A determination of the nuclear characteristics of DWPF canis- 
WSRC - SW 4-6

Part 5

Item 650

Page 2 of 4

Date: $7 / 91$

Revision $1 \mathrm{~A}$

PART TTTLE: CANISTERED WASTE EORM SPECIEICATIONS

ITEM TITLE: 3.10 SUBCRITICALITY SPECIEICATION

tered waste forms, based or the projected radionuclide inventories. This includes fdentification of bounding case(s).

- Calculation of $k_{e f f}$ for the bounding case(s).

Bounding Cases for DWRE Cantstered Waste Forms

A keff calculation was included in the DWPE facility's nuclear safety analysis prior to finalization of the DWPF design. The calculation was made on both Design-Basis glass, and on a glass contajning twice as much fissionable material as the Design-Basis glass. An infintte amount of material was assumed in the calculations.

In all cases the calculated neutron multiplication factor was quite low, keff $<0.15$. Doubling the plutonium and the $235 \mathrm{U}$ concentrations (with the other constituents reduced proportionately for normality), increased keff to 0.273 , but this value is low enough to provide an ample safety margin.

The calculations were repeated for three glass compositions which represent those expected to be produced in the DWPE during the first six to eight years of production (Batches 1,2 and 3 ).

Infinite neutron multiplication factor calculations for these three glass compositions were made with the computer code HRXN with Hansen-Roach neutron cross sections, 1 and other cross sections having the same energy group structure, generated at Oak Ridge National Laboratory, and furnished with the KENO-IV Monte Carlo criticality code. ${ }^{2}$ The mixtures were all assumed to be uniform in composition and infinite in amount.

For the Batch 1,2 and 3 glasses the calculated values of keff were $0.0019,0.0066$, and 0.0073 , respectively. Doubling the concentration of the fissile plutonium isotopes (239Pu and $241 \mathrm{Pu}$ ) while retaining the other plutonium isotopes at the same concentration, and doubling the concentration of the fissile uranium isotopes (233U and $235 \mathrm{U})$ while reducing the concentration of $238 \mathrm{U}$, increased the calculated values of keff for Batch 1, 2, and 3 to 0.0026 , 0.0081 , and 0.0092 , respectively. These values of $k_{e f f}$ provide am- 
WSRC $-S W 4-6$

Part 5

Item 650

Page 3 of 4

Date: $7 / 91$

Revision $1 \mathrm{~A}$

PART TITLE: CANISTERED WASTE FORM SPECIEICATIONS

ITEM TITLE: 3.10 SUBCRITICALITY SEECIEICATION

ple margin for uncertainties.

The calculated values of keff would be increased if apprectable amounts of water were interspersed in the infinite array of glass canisters considered in these calculations. However, the fissile isotope content of the glass is so low that it would not be possible to increase keff to exceed a critlcal value without introducing at least two orders of magnitude more fissile isotopes.

Decumentation

The Waste Form Qualification Report will include a report on the calculations showing that the effective multiplication factor of a canistered waste form will be much less than 1 , and that the safety margin exceeds $5 \%$. The report will include sufficlent information on the nuclear characteristics of the canistered waste form to enable the repository destgner to confirm subcriticality under repository storage conditions.

Beferences

1. G. E. Hansen and W. H. Roach, Six and Sixteen Group Cross Sections for Fast and Intermediate Critical Assemblies, USAEC Report LAMS -2543 (1961).

2. L. M. Petrie and N. F. Cross, KENO-IV - An Improved Monte Carlo Criticality Program, USAEC Report ORNL-4938, Oak Ridge National Laboratory, Oak Ridge, TN (1975).

3. H. C. Honeck, Tho JoshUA system, USERDA Report DP-1380, E. I. DuPont de Nemours and Co., Inc., Savannah River Plant, Aiken, SC (1975). 
WSRC $-S W A-6$

Part 5

Item 650

Page 4 of 4

Date: $7 / 91$

Revision $1 \mathrm{~A}$

EIGURE 5.650.1 Tasks planned to satisfy speutication 3.10, Subcriticality specification.

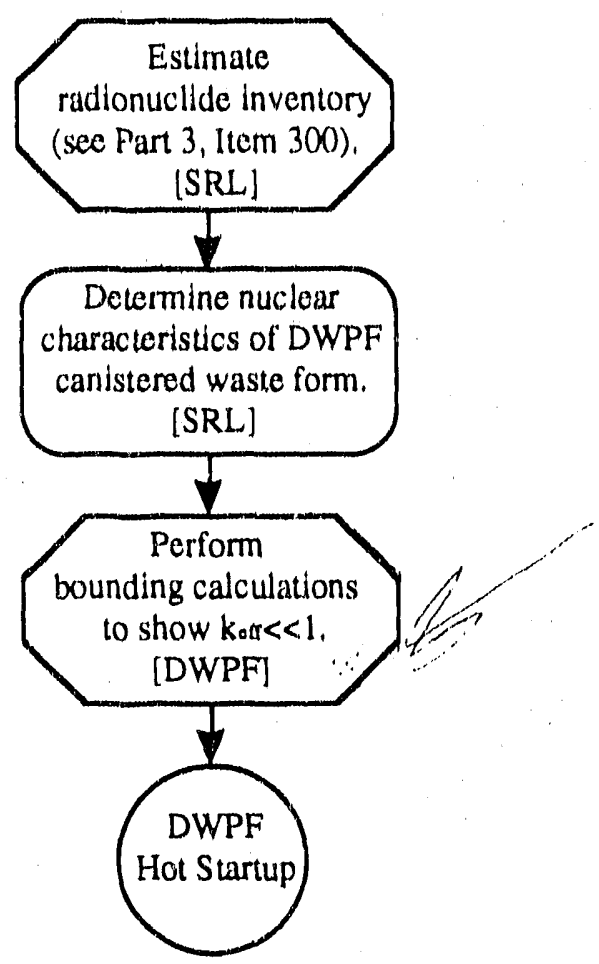




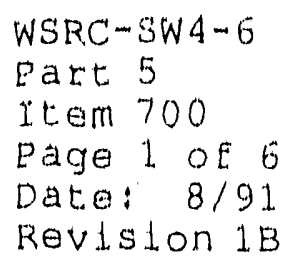

PART TITLE: CANISTERED WASTE EORM SPECIEICATIONS

ITEM TITLE: 3.11 SPECIEICATIONS EOR WEIGHT, LENGTH, DIAMETER, AND OVERALI DIMENSIONS

3.11 SPECIEICATIONS FOR WEIGHT, LENGTH， DIAMETER, AND OVERALI DIMENSIONS

The configuration, dimensions, and waight of tho canistered wasto form shalj. not exceed the maximum size and weight which oan be received, handled, and emplaced in the repository. These parameters shall be controlled as indicated below and shall be documented at the time of shipment. The producer shall describe the method of compliance in the WCP and the basis for compliance in the WQR.

\subsection{1 .1 Weight Specification}

The weight of the canistered waste form shall not exceed $3,500 \mathrm{~kg}$. The measured weight and estimated error shall be reported in the Storage and Shipping Records.

\subsection{1 .2 Length Specification}

The overall length of the final canistered waste form at the time of shipment shail be $3.000 \mathrm{~m}$ ( $+0.005 \mathrm{~m},-0.020 \mathrm{~m})$, including the neok and handing flange. The measured length and estimated orror shall be reported in the storage and Shipping Records.

\subsubsection{Diameter Specification}

The outer diameter of the canisterod waste form shall be $61.0 \mathrm{~cm}$ $(+1.5 \mathrm{~cm},-1.0 \mathrm{~cm})$. The measured diameter and estimated error shall be reported in the Storage and Shipping Records.

\subsubsection{Specification for overald Dimensions.}

The dimensions of the canistered waste form shall be controlled so that, at the time of shipment to a repository, the canistered waste form will stand upright without support on a flat horizontal surface and will fit without forcing when lowered vertically into a right-circular, cylindrical cavity, $64.0 \mathrm{~cm}$ in diametor and 3.01 m in length.

The producer shall state in the WQR the minimum canister wall thickness of the filled canister, and the thickness of any secondary canisters, along with their technical basis. The producer shall document the wall thickness in the production Rocords. 
$W S R C-S W A-6$

Part 5

It em 700

Page 2 of 6

Date: $8 / 91$

Revision $1 B$

PART TITLE! CANISTERED WASTE FORM SPECIEICATIONS

ITEM TITLE: 3.11 SEECIFICATIONS EOR WEIGHT, LENGTH, DIAMETER, AND OVERALI, DIMENSIONS

\section{Batisnale}

The specifioations on welght, length, and diameter of the canistored waste form are noeded for atorage, shipping, and repository design. The overall dimensions of the canistered waste form must be such that (1) no forcing is required to place it in the disposal package oontainer to prevent damage to the inside of the containex and (2) there is compatibility with container geometry.

\section{Complance Strategy}

Measurements of non-radloactive canlstered waste forms produced under conditions representing the range of those expected in the DWPE show that the vitrification process does not significantly affect the almensions of the canistered waste form. Thus, the DWPF will ensure that the dimensions of the canistered waste form are within the specifled limits by controlling the dimenstons of the purchased cantster. The weld plug will extend approximately $0.002 \mathrm{~m}$ above the nominal $3 \mathrm{~m}$ of canister length. The final weight of each DWPE canistered waste form will be measured in a shipping facility, prior to shipment from the DWPE to a repository. The minimum wali thickness is $0.86 \mathrm{~cm}$, based on the canister procurement specifications.

\section{Implementation}

The tasks planned to satisfy this specification are outlined in Elgure 5.700.1. These are

- Development of requirements for the canister length, diameter, and wall thickness, which have been fncluded in the canlster procurement specifications. This also includes identification of canister inspection requirements to ensure that the speciflcations are met at the vendor's shop.

- Determination of the change in canister dimensions during glass pouring at the pliot plant facilities.

- Determination of the additional length due to the weld plug $(0.2 \mathrm{~cm})$ or due to a repair weld cap.

- Design and qualification testing of a shipping facility. 
WSEC - SW $4-6$

Part. 5

Item 700

Page 3 of 6

Date: $8 / 91$

Revision LB

PART TITLE: CANISTERED WASTE FORM SPECIEICATIONS

ITEM TITLE: 3.11 SPECIEICATIONS EOR WEIGHT', LENGTH, DIAMETER, AND OVERALL DIMENS IONS

\section{Cantster erocurement spectetcattens}

The DWPF has developed detalled cantster procurement spectifications which specify the length, diameter, wall thickness, and overall dimenstons of canisters. In addition, inspection requirements are being defined, to ensure that the purchased canisters actudily meet speclfications before they leave the vendor's shop.

\section{Change in Dimenston During Pourtngi weld Rlug Hetght}

Seven prototyplcal DWPE canlsters were carefulily measured and then fliled with glass at the SRS pllot plant facility under both design basis (continuous filling) and the most likely upset (pouring rapldiy in short bursts) conditions. Seven canlsters were used so that estimates of uncertainties for each condition could be developed (however, the two data sets proved to be indistingutshable in terms of this speciflcation).

These canisters were then remeasured to determine the effects of canister fliling on canister dimensions. Flgure 5.700.2 contains a canister diagram indicating measurement locations, and the means and standard deviations of the measured dimensions. The diameter of the cantsters was measured at five different elevations: top end, top, middle, bottom, bottom end. The reported diameter value, $60.96 \pm 0.06 \mathrm{~cm}$, was calculated using measurements from all of the canisters at all elevations. The diameter 1 s well within the specification even after flliling (maximum deformation: $0.20 \pm 0.12$ $\mathrm{cm})$. Also included in the table is the calculated diameter of a cylinder large enough to contain the canister, taking into account ovality, and bow. As the table shows, the maximum cylinder is stil] within the specified limit of specification 3.11.4. Based on the small process-induced dimensional changes, it appears that compliance with the dimensional speciflcations can best be establishod through strict adherence to the canister procurement speciflcations. The WQR will provide the technical basis for this conclusion, and the detalis of the measurements and calculations.

The welghts of the protutyplcal canistered waste forms were also measured. The average weight of the glass was $\sim 1680 \mathrm{~kg}$. The average weight of the canister was $\sim 500 \mathrm{~kg}$. Thus, the total weight of each simulated cantstered waste form was $\sim 2.180 \mathrm{~kg}$, indicating 


WSRC-SW4-6
Part 5
Item 700
Page 4 of 6
Date: $8 / 91$
Revision 1B

PART TITLE: SANISTERED WASTE EORM SPECIEICATIONS

ITEM TITLE: 3.11 SPECIEICATIONS EOR WEIGHT, LENGTH, DIAMETER, AND OVERALI DIMENSIONS

that the DWPF should have little difficulty in meeting the weight specification.

Design, and oualification Testing of the Shipping Facility

The weight of the canistered waste form will be determined in a canister shipping facility prior to shipment to a repository. In addition, the overall dimensions of the canistered waste form will also be verified in the shipping facility prior to shipment. This will be done either through use of a template to ensure the right cylindricality and proper diameter and length of the canister, or through measurements. It is anticipated that a qualification program of the systems to measure canister weight and the overall dimensions of the canister will be carried out, to ensure that the procedures and equipment will satisfy the specification.

\section{Documentation}

The Waste Form Qualification Report will include the canister procurement specifications, and inspection procedures. The WQR will also include a report on the effect of the vitrification process on the canistered waste form dimensions.

The Production Record for each canistered waste form shall contain the as-purchased wall thickness of the canister.

The Shipping and Storage Record for each canistered waste form will include the length and diameter of the canistered waste form. The Shipping and Storage Record for each canistered waste form will also include the weight and a determination of the ability of the canister to fit without forcing into the specified cylinder. The weight will be obtained by weighing in the shipping facility. The diameter and length will be reported based on measurements of the canistered waste form prior to shipment from the DWPE. The ability of the glass-filled canisters to fit without forcing into the specified cylinder will be certified at time of shipment either based on the ability of the canister to fit, without forcing, into a template of the specified cylinder, or based on calculation of the minimum cylinder which can contain the canister. 
WSRC-SW4-6

Part 5

Item 700

Page 5 of 6

Date: $8 / 91$

Revision $1 B$

EIGURE 5.700.1 Tasks planned to satisfy specification 3.11 , Specifications for Weight, Length, Diameter and Overall Dimensions.

Specify length,

diameter, wall thickness
in canister procurement

documents. [DWPF]

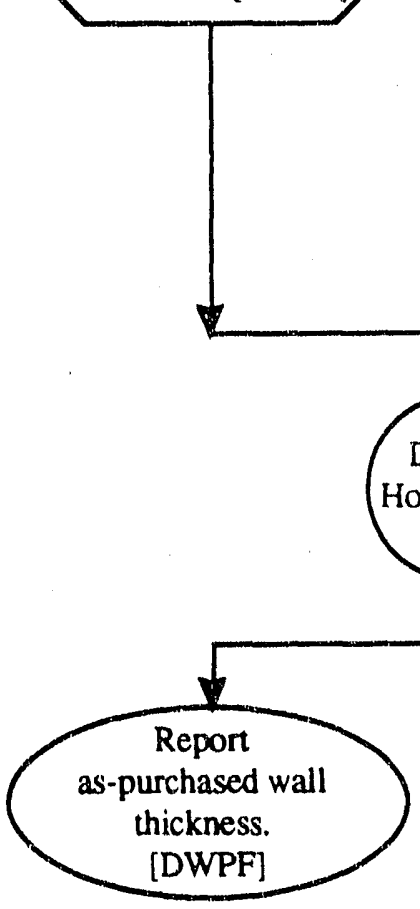

Determine additional

length due to weld plug

or repair cap weld.

[DWPF]

Determine

change in dimensions

during pouring.

[SRL]

DWPF

DWPF

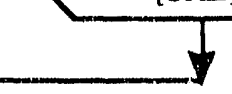

$\downarrow$

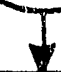


WSRC - SW $4-6$

Part 5

Item 700

Page 6 of 6

Date: $8 / 91$

Revision 1B

EIGURE 5.700 .2

Components and dimensions of DWPE canisters filled under design-basis and possible upset conditions in pilot plant tests (calculated for all canisters).

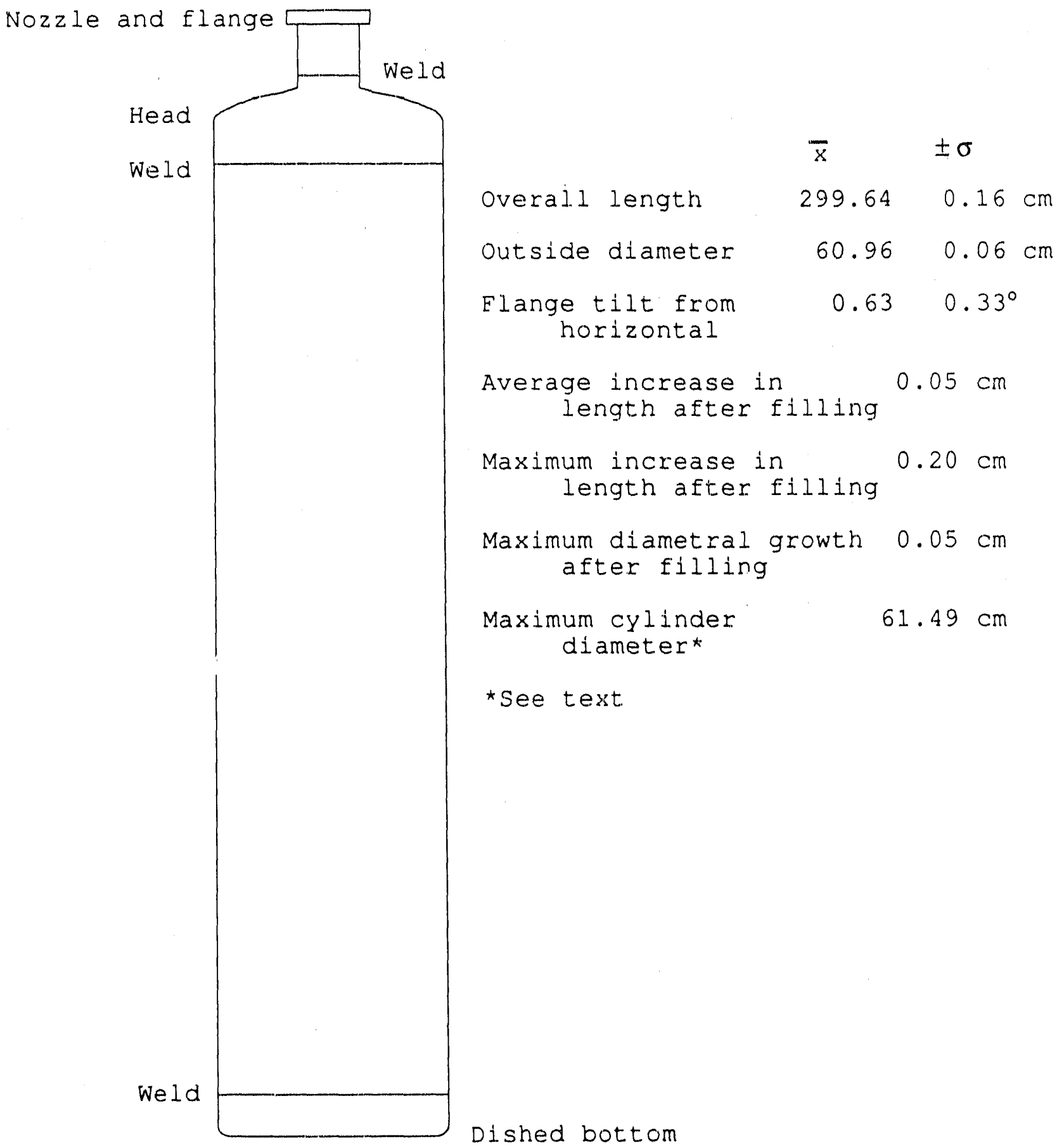


WSRC-SW $4-6$

Part 5

Item 750

Page 1 of 4

Date: $8 / 91$

Revision $1 \mathrm{~B}$

PART TITLE: CANISTERED WASTE FORM SEECIEICATIONS

ITEM TITLE: 3.12 DROP TEST SPECIFICATION

\subsection{DROP TEST SPECIEICATION}

The canistered waste form at time of shipment shall be capable of withstanding a drop onto a flat, essentially unyielding surface without breaching. The producer shall describe the method of compliance in the WCP and present the supporting documentation of analysis and test results in the WQR. The test results shall. include information on measured canister leak rates and canister deformation after the drop test.

The drop height to meet repository requirements shall be $7 \mathrm{~m}$.

The final Waste Acceptance Specifications will address the transportation requirements.

\section{Bationale}

This specification is intended to demonstrate that the canistered waste form can withstand severe physical impact without breaching. By requiring that the canistered waste form pass a performance (drop) test without breaching, this specification obviates the need for establishing detailed specifications on the material properties of the canister and the waste form necessary to describe the radionuclide source term associated with the possible breach of a canister as a result of a drop accident.

The drop height of 7 for the repository is based on the maximum lift design neight during repository operation.

Compliance strategy

The DWPE canister design has been qualified by testing canisters filled under both design-basis and the most likely process upset conditions (see part 5, Item 700). The results will be reported in the Waste Form Qualification Report. The DWPE will ensure a consistently robust canister (one able to withstand a $7 \mathrm{~m}$ drop) through control and verification of canister materials and fabrication (see Part 4, Items 100 and 200).

Implementation

The tasks planned to satisfy this specification are outlined in 
PART TITLE: CANISTERED WASTE FORM SPECIEICATIONS

ITEM TITLE: 3.12 DROP TEST SPECIEICATION

Eigure 5.750.1. They are

- Preparation of canisters for testing. Prototypical canisters procured according to the DWPE canister procurement specifications were filled under both reference process conditions, and under the most likely process upset conditions.

- Dropping the canisters $7 \mathrm{~m}$ onto an unyielding surface.

- Measurement of canister deformation and leak rate, to establish robustness of canister design.

- Control of the canister procurement process to ensure that the canisters used are consistently robust. This is achieved by ensuring that the canister satisfies the canister procurement specifications, as described in Part 4, Items 100 and 200, and Part 5, Item 700 .

\section{Rroduction of canisters for Testing}

The Savannah River Laboratory has previously dropped DWPE-like canisters from $9 \mathrm{~m}$, in a variety of orientations. ${ }^{1}$ No failures of DWPE-like canisters due to impact testing have ever been observed. This has been an important factor in finalizing the canister procurement specifications.

Canisters of the current DWPF design were procured for SRL by the DWPE, according to the current canister specifications (see Part 4, Items 100 and 200, and Part 5, Item 700). Seven canic ers were filled, four under reference process conditions, and three under conditions representing the most likely upset scenario (batch pouring), to the same levels expected for DWPE canisters (see Part 5, Item 300). These canisters were frit blasted, simulating th: decontamination process, and sealed in the same manner as in the DWPE (in some cases, with actual DWPE equipment).

\section{Testing of canisters and effects of Impacts ${ }^{2}$}

Strain circles were applied to the canister surface to indicate the magnitude of the strains exerted on the canisters during impact. These canisters were dropped from $7 \mathrm{~m}$, in two orientations: 
PART TITLE: CANISTERED WASTE EORM SPECIEICATIONS

ITEM TITLE: 3.12 DROP TEST SPECIEICATION

- The most likely - on the bottom.

- The most severe - on the head at an angle.

Each canister was tested by dye penetrant methods. Helium leak rate measurements were also made. All of the canisters survived the impacts without breaching.

\section{Documentation}

The Waste Form Qualification Report (WQR) will include a report on the bases of the drop tests, the results of the drop tests, and the effects of the impacts on the canister's leaktightness, dimensions, and integrity.

References

1. J. W. Kelker, SRI Canister Impact Tests, USDOE Report DP-1716, E. I. DuPont de Nemours, Inc., Savannah River Laboratory, Aiken SC (1986).

2. K. M. Olson, J. M. Alzheimer, Defense Waste Processing Facility Canister Impact Testing, Pacific Northwest Laboratory, Richland, WA (1989). 
WSRC-SW4-6

Part 5

Item 750

Page 4 of 4

Date: $8 / 91$

Revision $1 B$

Tasks planned to satisfy Specification 3.12, Drop Test Specification.

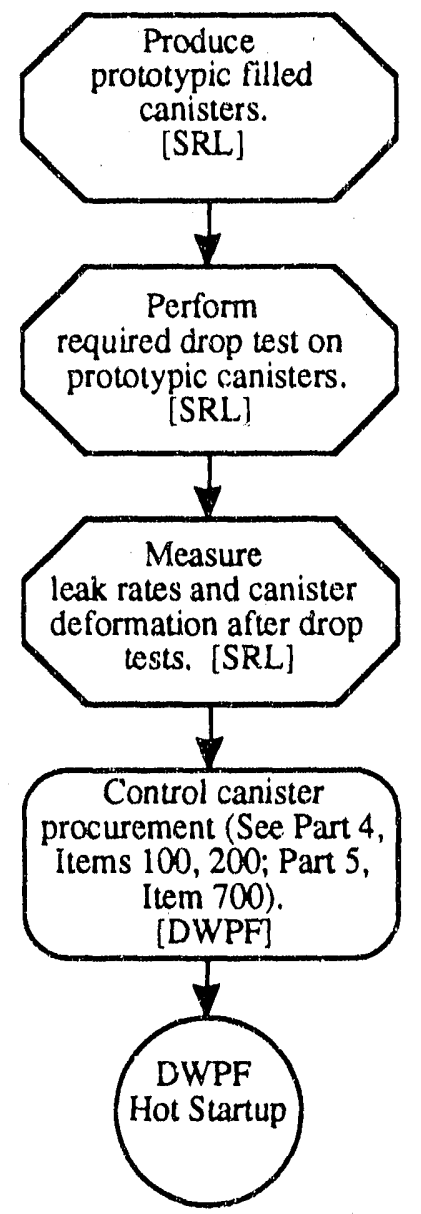


WSRC-SW4-6
Part 5
Item 800
Page 1 of 7
Date: $7 / 91$
Revision $1 \mathrm{~A}$

PART TITLE: CANISTERED WASTE FORM SPECIEICATIONS

ITEM TITLE: 3.13 HANDLING FEATURES SPECIEICATION

\subsection{HANDLING FEATURES SPECIFICATION}

The canistered waste form shall have a concentric neck and lifting flange. The lifting flange geometry and maximum loading capacity shall be described in the WCP.

The producer shall design the lifting flange and a suitable grapple, which could be used at the repository. The grapple and the flange shall be designed to satisfy the following requirements:

(a) The grapple shall be capable of being remotely engaged and disengaged from the flange.

(b) The grapple, when attached to a suitable hoist (to be supplied by the repository), and when engaged with the flange, shall be capable of raising and lowering a canistered waste form in a vertical direction.

(c) The grapple, in the disengaged position, shall be capable of being inserted into and withdrawn in a vertical direction from a right-circular cylindrical cavity with a dianetur equal to that of the canistered waste form.

The design of the flange and grapple shall be capable of fulfilling the requirements of Specification 3.13 (a) through 3.13 (c) without contacting or penetrating the walls of an imaginary rightcircular, cylindrical cavity with a diameter equal to that of the canistered waste form, coaxial with the canistered waste form. The design of the grapple shall include features that will prevent an inadvertent release of a suspended canistered waste form when the grapple is engaged with the flange. The producer shall describe the method used for demonstrating compliance in the WCP and provide the designs in the WQR.

\section{Bationalo}

This specification reflects the lifting and handling requirements necessary for compatibility with current wasta package concepts. The specification allows the waste producer maximum flexibility in design of the canistex handling arrangements, while ensuring that there are adequate handling features for repository design and operational purposes. This specification essentially limits the 
WSRC - SW $4-6$

Part 5

Item 800

Eage 2 of 7

Date: $7 / 91$

Revision $1 \mathrm{~A}$

PART TITLE: CANISTERED WASTE EORM SPECIFICATIONS

ITEM TITLE: 3.13 HANDLING FEATURES SPECIEICATION

\section{number of remotely operated lifting and handling grapples required at the repository.}

\section{Comoliance strategs}

The DWPF has designed a canister grapple which meets the design requirements above. Testing of the grapple has shown that it. meets the specification. In compliance with the specification, the DWPE will also supply designs of the canister flange and grapple to the repository. The canister procurement specifications require concentricity of the canister neck and flange.

\section{Implementation}

The tasks which have been planned to satisfy this specification are outlined in Eigure 5.800.1. They are:

- Design of the canister lifting flange, and determination of its maximum capacity.

- Design and testing of the canister grapple.

- Specification of requirements for the flange (including concentricity requirements) in the canister procurement specifications.

\section{Canister Lifting Elange}

The lifting flange geometry for the DWPF canister is shown in Figure 5.800.2; more detail is available from DWPF drawing \#W747391, revision 1.1, including method of attachment to the canister. A detailed design drawing of the lifting flange is incorporated in the canister procurement specifications. Calculations estimate its maximum loading capacity as 15,000 lbs. These calculations will be included in the waste Form Qualification Report.

\section{Design and Testing of Canjster Grapple}

The canister lifting grapple is specific for the DWPE canister and was developed by Remote Technology Corp. (REMOTEC) of Oak Ridge, TN. ${ }^{1}$ Grapple design features, and testing of the grapple, are summarized in Table 5.800.1. A photograph of an assembled unit used 
WSRC-SW $4-6$

Part 5

Item 800

Page 3 of 7

Date: $7 / 91$

Revision $1 \mathrm{~A}$

PART TITLE: CANISTERED WASTE FORM SPECIEICATIONS

ITEM TITLE: 3.13 HANDLING EEATURES SPECIFICATION

for testing is shown in Figure 5.800.3. A more detailed description of the grapple's design features, and of the testing of the grapple, will be provided in the Waste Form Qualification Report.

Decumentation

The Waste Form Qualification Report will include descriptions, and detalled drawings of the designs of the lifting flange and grapple. Test data from development and operability testing of the grapple will be included as well. A report detailing the calculation of the loading capacity of the canister neck and lifting flange will also be provider.

\section{References}

1. K. L. Walker, J. R. White, K. A. Earnstrom, R. E. Eversole, "Tanister Grapple for the Defense Waste Processing Eacility,"

Proceedings, $34 \mathrm{th}$ Conference on Remote Systems Technology, American Nuclear Society, 75-9 (1986). 


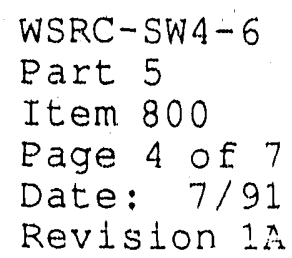

TABLE 5.800.1 Grapple design features, and testing.

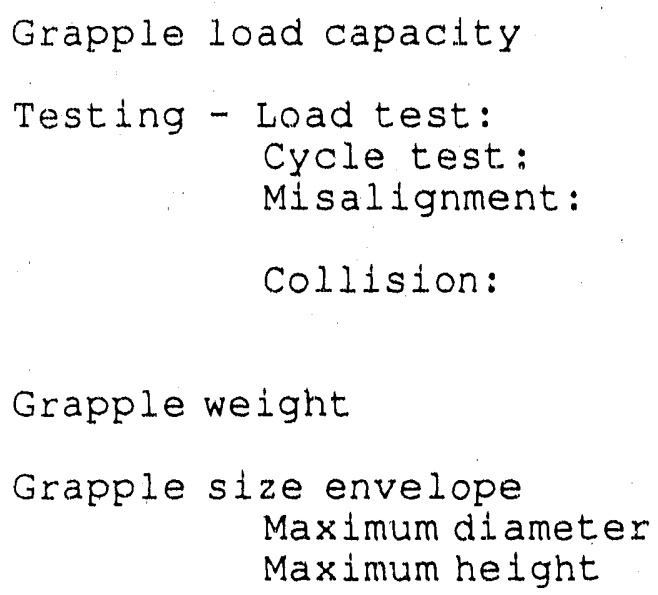

Design life

Maximum possible misalignment.

Release mechanism

Emergency release

Floor storage

Repair

Materials

Structural:

Sliding contact:

Bolting:
$6820 \mathrm{~kg}$

$125 \%$ of rated load

500 cycles at rated load

Engage canister neck with $25 \mathrm{~mm}$ off-set from grapple centerline. strike object with crane traveling at $9 \mathrm{~m} / \mathrm{min}$.

$238 \mathrm{~kg}$

$61 \mathrm{~cm}$

$107 \mathrm{~cm}$

Designed to be maintenance free for 60,000 cycles over a 5-year period.

The grapple is capable of plcking up a canister which is out of alignment up to $25 \mathrm{~mm}$ in any direction.

Two-step release of canister; canister must be set down twice before grapple will release canister.

Canister can be released under emergency conditions using a master/slave manipulator (force required: $4 \mathrm{~kg}$ ).

Self-supporting

Contact maintenance after high pressure wet decontamination.

304 L stainless steel. Nitronics 50 . 304 stainless steel bolts, 410 stainless steel nuts. 


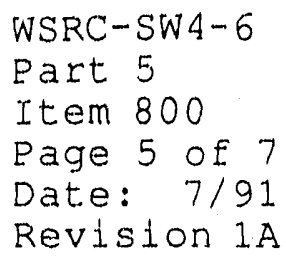

FIGURE 5.800.1 Tasks planned to satisfy specification 3.13, Handiling Features Specification.
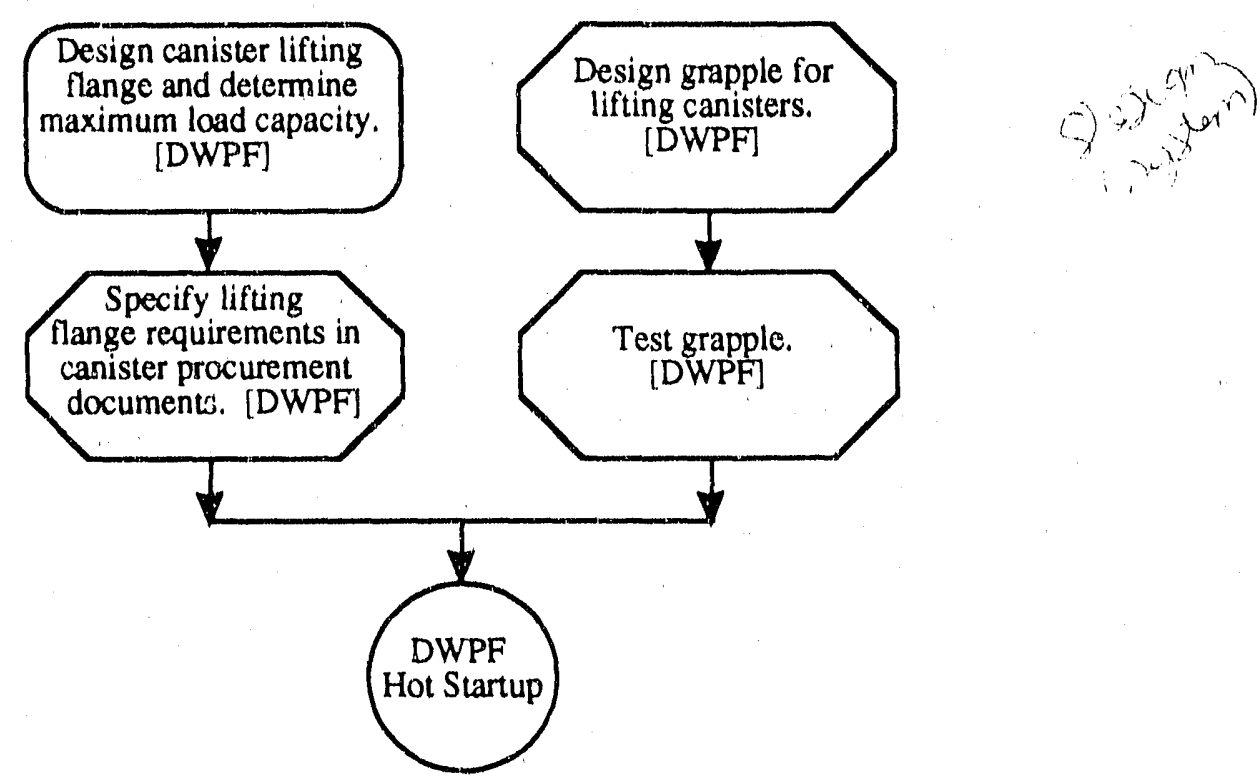
WSRC $-5 W 4-6$

Part 5

Item 800

Page 6 of 7

Date: $7 / 91$

Revision $1 \mathrm{~A}$

ETGURE 5.800.2 Lifting Flange Geometry for DWPE Canisters

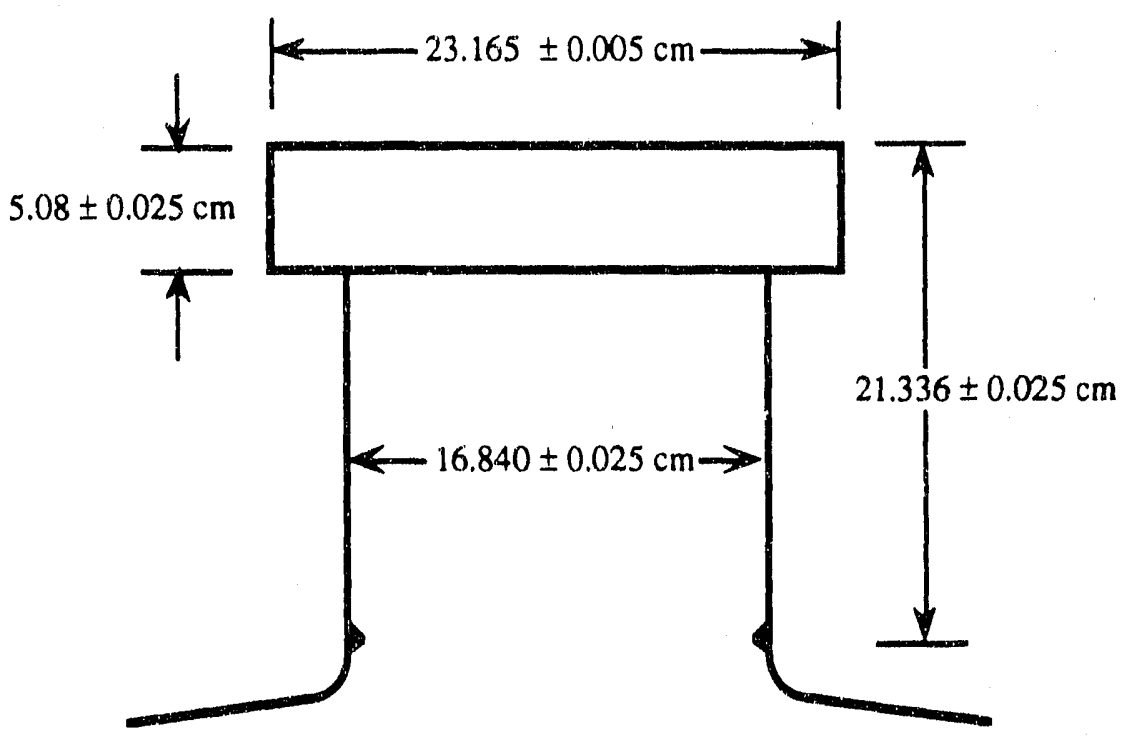


WSRC--SW 4-6

Part 5

Item 800

Page 7 of 7

Date: $7 / 91$

Revision $1 \mathrm{~A}$

\section{FIGURE 5.800.3 DWPE Canister Grapple}

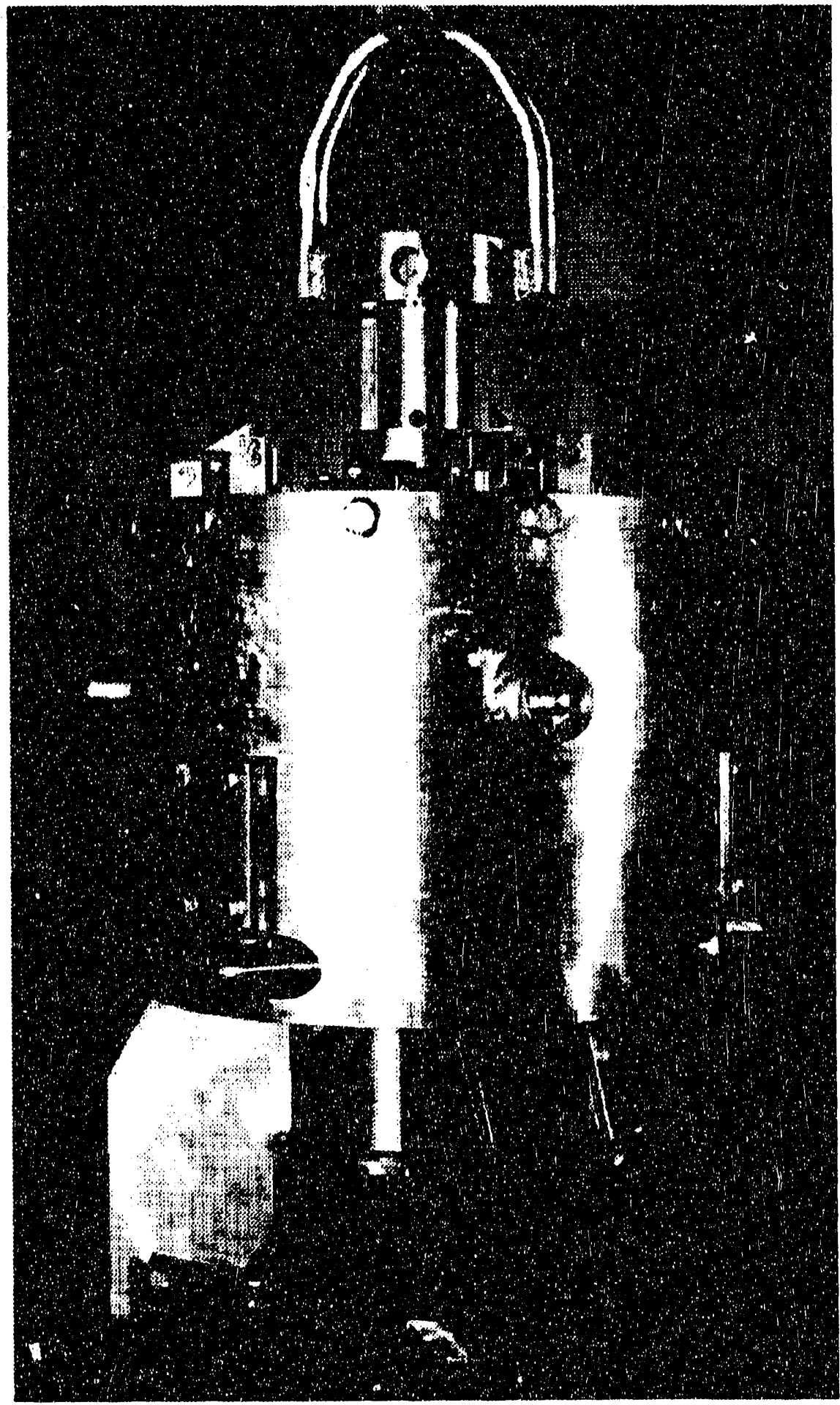


WSRC-SW4-6

Part 6

Item 100

Page 1 of 1 .

Date: $8 / 91$

Revision $1 B$

PART TITLE: QUALITY ASSURANCE

ITEM TITLE: SELECTIVE APPLICATION OF QUALITY ASSURANCE PROGRAM

The quality assurance requirements for waste form production require that the DWPF identify those items which are of importance to product acceptance. The purpose of identifying items is to signify their importance to product acceptance objectives, so that appropriate mechanisms can be established for their control. It is also required that the DWPE identify, in the Waste Eorm Compliance Plan, the methodology used to select items and activities to be controlled for waste acceptance purposes.

SRI has identified those items and activities to be controlled, based on the Waste Form Compliance Plan. For inclusion in the list of items to be controlled, an item had to meet the following criteria (for purposes of identification, procedures were considered to be items):

- The item must be an essential part of compliance with one or more of the specifications, based on the strategies defined in the Waste Form Compliance Plan. Thus, the neutron system for glass level detection in the canister is included, but the load cells on the melter turntable are not.

- The item either exists now, or is well-enough defined so that the form of implementation is very certain. The specifications for the DWPE product require reporting of several parameters at time of shipment. Included are weight, heat generation, smear test results, and dose rate. These were not identified as controlled items because they will be part of a shipping facility which is not yet even designed. Comparable measurements which will be made within the DWPF (e.g., smear results) for process control purposes were also not included, because they are not part of DWPE product acceptance.

The listing of controlled items and activities is maintained by the DWPE's Waste Compliance Group.

\section{Beference}

1. Quality Assurance Requirements Document, USDOE Document RW0214, Revision 4, Office of Civilian Radioactive Waste Management, Washington, DC, October, 1990. 


WSRC-SW4-6
Part 6
Item 200
Page 1 of 1
Date: $8 / 91$
Revision 1 B

PART TITIE: QUALITY ASSURANCE

ITEM TITLE: CHANGES RELATING TO WASTE ACCEPTANCE PROCESS ACTIVITIES

Under certain circumstances, changes in the activities described in the Waste Eorm Compliance Plan may be desirable. These circumstances include, but are not limited to, the following:

- Unexpected results of performing a Waste Acceptance Process activity could indicate a need to significantly change the course of the subsequent actions.

- Changes in the DWPF process could require different, or additional, Waste Acceptance Process activities.

- Improved technology, not foreseen when the WCP was formulated, could significantly enhance the quality of waste Acceptance Process activities.

To allow such beneficial changes, the following procedure will be followed. This procedure will take effect as soon as the office of Civilian Radioactive Waste Management concurs with the DWPF Waste Form Compliance Plan.

1. DWPF will identify a need for a change in the waste Acceptance Process activities identified in the Waste Form Compliance Plan, and notify DOE-SR's High Level Waste Division (HLWD) of this need, in writing.

2. DWPE will develop a justification for the proposed change. This justification will describe the proposed change, the reasons for making the change, and the expected impact of the change on other waste Acceptance Process activities.

3. DWPE will transmit the proposed change and j.ts justification to the HLWD, for review and comment. The HLWD will be responsible for transmittal of the proposed change and its justification to other affected organizations (e.g. the office of Civilian Radioactive Waste Management), and for transmitting comments back to DWPE.

4. DWPF will disposition any comments received, and transmit the disposition to the HLWD for approval.

5. After approval is recelved from the HLWD, DWPF will implement the change. 
Pages 1 thru 21 are unavallable.

WSRC - SWA -6

A.PEENDIX 1.100 .1

Page 22 of 28

can be performed remotely in a hot-cell environment. The three elements to be analyzed (lithium, sodium and boron) for the PCT are sufficient, because they release faster than all other elements for all conceivable types of borosilicate HLW glass.

\subsection{RATIONALE FOR THE SPECIFICATION FOR PHASE STABILITY}

The specification will provide data useful to the repository project for establishment of repository and waste package design temperature limits. The certifications required will provide assurance that the producer has not handled or stored the waste forms in such a way as to cause changes in the phase structure that could significantly affect glass properties.

The available evidence[5] indicates that the borosilicate glass waste form will retain properties similar to those obtained under Specification 1.3 so long as the phase structure and composition of the glass are unchanged from those provided under specteication 1.1. The evidence also indicates that neither energy input nor radioactive decay significantly affect release from waste glass, as long as the temperature of the glass does not exceed the glass transition temperature (approximately $500^{\circ} \mathrm{C}$ ). Above this temperature, significant changes in phase composition can occur.

\section{CANISTER SPECIEICATIONS}

\subsection{RATIONALE FOR T'HE MATERIAL SPECIEICATION}

The repository must have a complete materials inventory to evaluate longterm performance under repository conditions. Austenitic stainless steel has been selected as the canister maturial. This specification acknowledges that fact and establishes the repository's interest in this interface. The current role of the canister as part of the engineered barrier system does not require the canister to act as a post-closure engineered barrier; therefore, the primary requirement of the canister material specification is to ensure that the canister material does not have an adverse impact on waste package performance. By specifying austenitic stainless steel manufactured to ASTM specifications, this requirement is met. Additionally, identification of the materials is necessary to assure that the canister material, and the material of any other component (i.e." secondary canisters and welding fillers), are compatible with other materials in the re-pository.

\subsection{RATIONALE EOR THE EABRICATION AND CLOSURE SPECIEICATION}

The sealed canister is designed to provide confinement of the waste and protection of the waste form from contact with externally derived liquids and gases until the canister is sealed in a repository container. The canister itself is not intended to meet a post-closure containment requirement. A leak rate of less than $2 \times 10^{-4} \mathrm{~atm}-\mathrm{cc} / \mathrm{sec}$ has been established [6] as being sufficient to 
prevent water from entering the canister. A leak rate of $10^{-4}$ atm$\mathrm{cc} / \mathrm{sec}$ (air) has been established as the container failure criterion for repository post-closure service [7]. Thus, a final closure leak-rate specification of $10^{-4}$ atm-cc/sec (helium) for canisters of HLW glass is considered to be both conservative and demonstrable.

\subsection{RATIONALE FOR THE IDENTIEICATION AND LABELING SPECIFICATIONS}

The regulatory requirements in 10 CER 60.135 (b) (4) state "A iabel or other means of identification shall be provided for each waste package. The identification shall not impair the integrity of the waste package and shall be applied in such a way that the information shall be legible at least to the end of the pertod of retrlevability. Each waste package identification shall be consistent with the waste package's permanent written records."

This specification provides a means of tying the waste package and the canistered waste form together through closure of the repository. The 92 point sans serif type face (or equivalent) results in a letter height and width of approximately $3 \mathrm{~cm}$ by $2 \mathrm{~cm}$ which has been confirmed through observation to be adequate dimensions for visibility. The canister label. is needed to identify the canistered waste form through storage at the producer's facility, shipment co the repository, and possible lag storage at the repository prior to final prckaging. Once the canistered waste form is recelved at the repusitory, the burden of maintaining the identity of the contents shifts to the repository project.

3. CANISTERED WASTE FORM SPECIEICATIONS

\subsection{RATIONALE EOR THE EREE LIOUID SPECIFICATION}

The regulatory requirements outlined in $10 \mathrm{CFR} 60.135$ (b) (2) state that, "The waste package shall not contain free liquids in an amount that could compromise the ability of the waste package to achieve the performance objectives relating to containment of HLW (because of chemical interactions or formation of pressurized vapor) or result in spillage and spread of contamination in the event of waste package perforation during the period through permanent closure."

\subsection{RATIONALE FOR THE GAS SPECIEICATION}

The regulatory requirements in 10 CFR 60.135 (a) require that "packages for HLW shall be designed so that in-situ chemical, physical, and nuclear properties of the waste package...do not compromise the function of the waste packages..." and "The design shall include...consideration of...oxidation/reduction reactions, corrosion, hydriding, gas generation, thermal effects.... radiolysis, radiation damage..." In order to demonstrate compliance with the regulations, waste package designers require information on gas generation potential of the waste form. 
WSRC-SW4-6

APPENDIX 1.100 .1

Page 24 of 28

The intent of this specification is to ensure that gas pressure will not build up inside the container and contribute to loss of containment and dispersion of radionuclides. This specification provides'a limit to initial gas pressure and information from which to index the calculation of gas pressure build-up with time due to nuclear decay and temperature changes.

The value for the maximum initial gas pressure, $150 \mathrm{kPa} 22$ psia), was chosen because it has the following attributes: it is low enough to preclude significant stresses in the canister wall arising from internal pressurization, both initially and after the anticipated helium production from alpha decay over the containment period; also, it avoids introducing unnecessary restrictions that will not materially contribute to the overall function of the canistered waste form in the repository.

In general, an internal pressure $P$ in a cylindrical vessel of diameter $D$ and wall thickness $t$ produces tensile hoop stress of $\sigma_{H}=P D / 2 t$ and a tensile longitudinal stress of $\sigma_{L}=P D / 4 t$ in the wall of the vessel [8]. For a vessel made from Type 304L stainless steel, the yield strength at $500^{\circ} \mathrm{C}$ would be at least $96 \mathrm{MPa}$ (14,000 ps1) [9]. The more rapid cooling of the cantster wall than the bulk of the glass after pouring as well as differences in the coefficients of thermal expansion of the two materials are expected to lead to tensile thermal stresses approaching or exceeding the yield strength of the stainless steel [9]. In order for the stresses due to internal pressurization to be insignificant in comparison, it would be sufficient to limit them to a small percentage of the yield strength. If the hoop stress is limited to 10 percent of the yield strength at $500^{\circ} \mathrm{C}$ or $9.6 \mathrm{MPa}$ (1400 psia), the maximum internal pressure, based on a $1 \mathrm{~cm}(3 / 8$ in.) thick wall, would be $300 \mathrm{kPa}(44 \mathrm{psia})$ at $500^{\circ} \mathrm{C}$, which is equivalent to $116 \mathrm{kPa}$ (17 psia) at $25^{\circ} \mathrm{C}$.

The maximum pressure increase due to helium release from alpha decay after 1000 years has been calculated to be less than $7 \mathrm{kPa}$ ( 1 psi) [10]; therefore, an initial pressure less than about $123 \mathrm{kPa}$ (18 psia) would therefore appear to be conservative. With these guidelines, a value of about $1-1 / 2$ atmospheres, or $150 \mathrm{kPa}(22$ psia), was chosen as conservative and practicable. In actuality, the pressure (evaluated at $25^{\circ} \mathrm{C}$ ) immediately after canister sealing is expected to be much less than $150 \mathrm{kPa}(22 \mathrm{psia})$, due to cooling after sealing.

\subsection{RATIONALE FOR THE SPECIFICATION FOR EXPLOSIVENESS, PYRO-} PHORICITY, AND COMBUSTIBILITY

This spectfication is needed to ensure that after closure, the canistered waste form does not explode or burn during normal re-pository operations and accident conditions.

The regulatory requirements as outlined in $10 \mathrm{CFR} 60.135$ (b) (1) state that, "The waste package shall not contain explosive or py- 
rophoric materials .... in an amount that could compromise the ability of the underground facility to contribute to waste isolation or the ability of the geologic repository to satisfy the performance objectives."

The regulatory requirements on the waste package as outlined in 10 CER 60.135 (a) (2) state that, "The design shall include but not be limited to consideration of...fire and explosion hazards." The waste form, as a component of the waste packages must comply with this requirement.

\subsection{RATIONALE FOR THE ORGANIC MATERIALS SPECIFICATION}

This specification is needed to ensure thac organic materials that tend to mobilize radionuclides by formation of complexes or generate gases due to radiolysis are not present in the canistered waste form in significant amounts.

The regulatory requirements on the waste package as outined in 10 CER 60.135 (a) (2) state that, "The design shall include but not be limited to consideration of the following factors: ...gas generation, radiolysis, radionuclide retardation, leaching..." The waste form, as a component of the waste package must be assessed for compliance.

\subsection{RATIONALE FOR THE EILL HEIGHT SPECIFICATION}

In general, the free volume, as measured by the fill height is to be minimized to minimize the needed repository space.

\subsection{RATIONALE FOR THE SPECIFICATION FOR REMOVABLE RADIOACTIVE CONTAMINATION ON EXTERNAL SUREACES}

This specification is necessary to protect personnel, prevent uncontrolled spread of contamination during transportation and in repository facilities, minimize need for remote maintenance of facility equipment, and minimize need for cleanup of contamination during normal operations.

The specification limits chosen are used extensively in the nuclear industry practice (e.g.. for compliance with 10 CER 71.87) to indicate surfaces are free of removable contamination.

\subsection{RATIONALE FOR THE HEAT GENERATION SPECIEICATION}

A heat generation rate limit ensures that the temperatures reached in other disposal package components or the host rock do not significantly reduce their performance capabilities.

Repository designers need heat generation rate values to ensure that repository thermal load limits are not violated. The value of 1500 watts was chosen as an expected upper bound for production for any HLW glass production facility. 
WSRC-SW4-6

APPENDIX 1.100 .1

Page 26 of 28

Information on the range of expected variation in heat generation rates is necessary to allow assessment of variation in repository performance and to optimize repository emplacement design.

\subsection{RATIONALE FOR THE SPECIEICATION EOR MAXIMUM DOSE RATES}

The repository project needs the maximum gamma and neutron dose rates in order to design shielding for the receipt and handling facilities. This information is also needed by the shipper to provide adequate transportation casks. The values of $10^{+5} \mathrm{rem} / \mathrm{hr}$ for maximum gamme dose rate and $10 \mathrm{rem} / \mathrm{hr}$ for maximum neutron dose rate provide a reasonable basis for repository design and operation and are judged to be sufficiently above the expected dose rates for HLW glass waste forms to provide reasonable flexibility for normal operations.

\subsection{RATIONALE FOR THE CHEMICAL COMPATIBILITY SPECIEICATION}

The specification is required to assure that the canister can be safely handled during storage, transportation, and repository operations, and to provide needed data for assessment of long-term performance of the waste package components.

The regulatory requirements on the waste package as outlined in 10 CFR 60.135 (b) (1) state that "The waste package shall not contain....chemically reactive materials in an amount that could compromis:e the ability of the underground facility to contribute to waste isolation or the ability of the geologic repository to satisfy the performance objectives."

\subsection{RATIONALE FOR THE SUBCRITICALITY SPECIEICATION}

The regulatory requirements as outlined in 10 CFR 60.131 (b) (7) state that, "The calculated effective multiplication factor (keff) must be sufficiently below unity, to show at least a 5 percent margin, after allowance for the bias in the method of calculation and the uncertainty in the experiments used to evaluate the method of calculation."

3.11 RATIONALE FOR THE SPECIEICATIONS FORWEIGHT, LENGTH, DIAMETER, AND OVERALL DIMENSIONS

The specifications on weight, length, and diameter of the canistered waste form are needed for storage, shipping, and repository design. The overall dimensions of the canistered waste form must be such that (1) no forcing is required to place it in the disposal package container to prevent damage to the inside of the container and (2) there is compatibility with container geometry. 


\subsection{RATIONALE EOR THE DROP TEST}

This specification is intended to demonstrate that the canistered waste form can withstand severe physical impact without breaching. By requiring that the canistered waste form pass a Farformance (drop) test without breaching, this speclfication obviates the need for establishing detailed specifications on the material properties of the canister and the waste form necessary to describe the radionuclide source term assoctated with the possible breach of a canister as a result of a drop accident.

The drop helght of $7 \mathrm{~m}$ for the repository is based on the maximum lift design height during repository operation.

\subsection{RATIONALE FOR THE HANDLING EEATURES SPECIFICATION}

This specification reflects the lifting and handling requirements necessary for compatibility with current waste package concepts. The specification allows the waste producer maximum flexibility in design of the canister handling arrangements, while ensuring that there are adequate handling features for repository design and operational purposes. This specification essentially limits the number of remotely operated lifing and handling grapples required at the repository.

\section{RATIONALE FOR THE QUALITY ASSURANCE SPECIEICATION}

All activities relevant to licensing of a repository must be conducted in accordance with appropriate quality assurance zontrols. The Office of Civilian Radioactive Waste Management's quality assurance policies and requirements applicable to the high-level waste form production are described in the referenced document. High-level waste form production activities must be conducted in compliance with the quality assurance policies and requirements established by the office of Civilian Radioactive Waste Management. 
WSRC-SW4-6

APPENDIX 1.100 .1

Page 28 of 28

APPENDIX B

REEERENCES FOR WASTE ACCEPTANCE PRELIMINARY SPECIF ICATIONS EOR VITRIEIED HIGH-LEVEI WASTE EORMS

(1) U.S. Department of Energy, Office of Civilian Radioactive Waste Management, Waste Management System Requirements Document, Volume I: General systems Reguirements, Volume IV: Mined Geologic Disposal System, Latest Revision.

[2] U.S. Nuclear Regulatory Commission, 10 CFR Part 60, Disposal of High-Level Radioactive Wastes in Geologic RepositoriesTechnical Criteria.

[3] Jantzen, C.M., "Nuclear Waste Product Consistency Test Method Version 3.0," WSRC-TR-90-539, Savannah River Laboratory, November, 1990.

[4] U.S. Department of Energy, Environmental Assessment-Waste Form Selection for SRP High-Level Waste, USDOE Report DOE/EA 0179, Washington, DC (1982).

[5] Bickford, D.F. and Jantzen, C.M., "Devitrification Behavior of SRL Defense Waste Glass," Sclentlflc Basis for Nucleax Waste Management VII, G.L. MCVay (ed.), Elsevier, NY, 557-66 (1984).

[6] Light, G.M., "Investigation of Nondestructive Evaluation Techniques for Inspection of Nuclear Waste Canisters," Southwest Research Institute Report on Project 7588, February, 1984 .

[7] U.S. Department of Energy, "Site Characterization Plan, Yucca Mountain Site," DOE/RW-0199, December, 1988.

[8] Popov, E.P., Mechanics of Materials, Prentice-Hal1, Englewood Cliffs, NJ, pp. 225-8 (1959).

[9] ASM Metals Handbook, Ninth Edition, Vol. 3, ASM International, Materials Park, OH, p. 192 (1980).

[10] Baxter, R.G., "Description of Defense Waste Processing Facility Reference Waste Eorm and Canister," DP-1606, Rev. 2, E.I. du Pont de Nemours and Co., Savannah River Plant, Aiken, SC, p. 16 (1988). 
WSRC-SWA- 6

APPENDIX 1.200 .1

Page 1 of 8

Date: $8 / 91$

Revision $1 \mathrm{~B}$

DESCRIPTION

OE THE PRODUCTION RECORDS F'OR

DWPF CANISTERED WASTE FORMS 
WSRC-SW4-6

APPENDIX 1.200 .1

Page 2 of 8

Date: $8 / 91$

Reviston $1 B$

APRENDIX 1.200.1 Description of the DWPE Production Records

\section{INTRODUCTION}

The Department of Energy's Offlce of Civilian Radioactive Waste Management has established specifications the DWPE product must meet to be acceptable for disposal at a refository. These waste Acceptance Preliminary Specifications (WAPS) require that the DWPF provide evidence of compliance with the WAPS during production. This evidence is to be documented, and sent to the repository, in the form of production Records for DWPF canistered waste forms. In this Appendix, the content of the Production Records is detailed, based on the WAPS and the waste Acceptance Process activities described in the DWEF Waste Form Compliance Plan.

\section{CONTENT}

The Production Records summarlze the detalled records of DWPE canistered waste form production. The Production Record will provide references to these detalled records (primarliy through canister and batch identifications) so that more detailed information can be retrleved, if necessary. The DWPF will print paper coples of the Production Records as they are generated, and will provide them to the repository as soon as they are completed and reviewed for accuracy. The information to be reported is summarized in Table 1.200.1.1. Any actions to be taken based on the information are identified below.

\section{Macro-batches}

The "macro-batch" is a key concept for compliance with the chemical composition, the radionuclide inventory, and the product consistency specifications. The feed to the DWPE from processing of soluble salts is expected to change only three times a year, and then only very slowly because of "heels" in the waste tanks. The insoluble sludge batches will change even less frequently (every two to three years). Thus, the feed $=0$ the DWPF will remain fairly constant for periods of at least three to four inonths at a time. These periods of constant feed constitute macro-batches, which the DWEE will treat as the "waste types" referred to in the specifications.

\section{Ident ification and Labeluting}

The Production Records will identify particular canisters by the code on the label affixed to them. This code, unique to each canister, will be the key to tracing the records for each canistered 
WSRC-SW4- 6

APPENDTX.1.200.1

Page 3 of 8

Date: $8 / 91$

Revision iB

waste form. A.l of the records which support the information reported in the production Records will be keyed to that code.

\section{Iiming}

The DWPE will provide the Production Records to the repository program, as soon as possible after processing of a macro-batch is completed. This will allow the repository program tu review the content of the Production Records in a timely manner, to identify any potential problems, and to include pertinent information from them in the license application for the repository. The Production Records will be treated as lifetime quality records by the DWPE.

\section{Use of Glass Samples}

Samples of production glass will occasionally be taken from the Melt Cell (see Part 3, Items 200, 400, and 500), and sent to SRL to confirm compliance with specification 1.3 (Product Consistency), and for chemical and radiochemlcal analyses. SRL will report these results to the DWPF as toplcal reports, keyed to the number of the canister being fllied during sampling. Paper copies of these reports will be included in the production Records for the particular canister in question. SRL's Defense Waste Processing Technology section (SRL/DWPTS) will be responsible for providing these wricten records to the DWPF, in a manner suitable for longterm storage. These reports w1ll also be treated as lifetime quality records.

\section{Chemical compesition During Rerduction}

The WAPS require that the DWPE report the content of all elements, excluding oxygen, which are present in concentrations greater than 0.5 wt of the glass, expressed as oxides. This information will be calculated from analyses of samples from each process batch.

The values to be reported in the production Records will be the numerical average and standard deviation calculated from the individual elemental analyses for an entire macro-batch, expressed as oxides in the glass. Thus, the reported chemical composition will be the same for all canisters produced from a given macro-batch of feed.

The form for this record contains: 
WSRC-SW4 -6

ARPENDIX 1.200 .1

Page 4 of 8

Date: $8 / 91$

Revision $1 \mathrm{~B}$

- The canister number.

- The macro-batch number.

- The process batch number.

- Each major (present at greates than 0.5 wt $q$ ) element, expressed as its oxide, and the content of the oxide, the calculated standard deviation for the analysis, and the number of analyses performed.

\section{Badionuclide Inyentery During Production}

The WAPS require that the DWPE report estimates of the inventory of all radionuclides with half-lives greater than 10 years, and present in the glass at greater than 0.05 of the total radionuclide inventory at any point up to 1100 years after production. This information will be calculated from radiochemical and chemical analyses of samples from each process batch.

The values to be reported in the Production Records will depend on the particular radionuclide (see Eart 3, Item 400). For all radionuclides, the reported inventory is the same for an entire macrobatch, and is expressed as curies per canister.

The form for this record contains:

- The canister number.

- The macro-batch number.

- The process batch number.

- Each radionuclide, and its calculated content.

There are no limits on the radionuclide inventory itself. However, as discussed below, the values will be used to calculate the heat generation rate, which has a specified limit. Thus, the limit on heat generation rate constitutes a sort of limit on the allowed radionuclide inventory.

\section{Rroduct Censistency}

The DWPE will report the normalized lithium, sodium and boron concentrations on the PCT predicted from the average composition of 
WSRC-SW $4-6$

APPENDIX 1.200 .1

Page 5 of 8

Date: $8 / 91$

Revision $1 \mathrm{~B}$

each macro-batch. Thus, the predicted PCT results will be the same for every canistered waste form in the macro-batch. The DWPE will also certify that this value is at least two standard deviations below the mean of the PCT results for the benchmark glass of specification 1.3. In addition, the results of performing the PCT on production samples of glass will also be reported.

If the predicted PCT results do not satisfy the specification, the group of glass-filled canisters will be identified as nonconforming items, to be dispositioned as outlined in Part 6, Item 800 .

Thus, the production Record will contain

- The normalized concentrations of lithium, sodium and boron, predicted from the composition.

- The results of performing the PCT on actual production samples of glass (if any).

\section{Canister Material, Eabrication and closure. Wall Thickness}

The WAPS require that the DWPF identify the canister materials in the production Records, certify that the closed canister is leaktight, and report the wall thickness of each canister. The Production Records will reference the procurement documents for the canister. Procurement documents wil.1 include specifications, purchase orders, vendor and heat identification, certificates of analyses, wall thickness measurements, and inspection records.

The Production Records will summarize the welding parameters measured by the canister welder's data acquisition system. If these values are outside the range of parameters which have been shown to produce a leaktight weld (Part 4, Item 200), a flag is set which identifies the canister weld as a nonconforming item, which is dispositioned as described in Part 6, Item 800 of the WCP. If a repair weld is applied, the production Records will summarize the welding parameters associated with application of that weld.

The Production Records will contain:

- Canister number.

- Vendor name.

- Order number. 
WSRC-SW4-6

APPENDIX 1.200 .1

Page 6 of 8

Date: $8 / 91$

Revision $1 \mathrm{~B}$

- Material composition data sheets from the vendor.

- Results of any verification of canister materials at Savannah River before canister filling, and identification of the individual (s) performing the verification. Non-conforming canisters will not be accepted from the vendor for DWPE use.

- The maximum force and current applied during closure of the canister in the DWRE, the duration of application of the force and current, and distance the ram traversed during canister closure.

- Results of inspections of canister closure welds and their uniformity.

- Wall thickness measurements.

Canister content controls

The WAPS has no documentation requirements for exclusion of foreign materials (those excluded by specifications 3.1 to 3.4). However, because of the importance of the Inner Canister closure in meeting this specification, its leak rate will be reported.

The Production Records will include the following information on the Inner Canister Closure:

- Canister number.

- Results of canister flange inspection, and identiflcation of the inspector.

- Temporary plug number.

- Measured leak rate of the inner canister closure (ICC).

- Calculated leak rate of the ICC, and identification of an excessive leak, which requires use of a repair ICC.

- Identification of an ICC as a repair ICC, and the parameters associated with it (e.g., leak rates).

Canister Fidd Level

The WAPS require that the DWPF report, in the Production Records, 
WSRC - SW $4-6$

APPENDIX 1.200 .1

Page 7 of 8

Date: $8 / 91$

Revision $1 \mathrm{~B}$

the fill level within each canister. This information will be obtained from both the neutron and gamma level detectors. The production Records will report both values.

Although there is a nominal minimum fill height of 808 of the total internal volume, it is recognized in the WAPS that during production this may not always be met. The production Records for each canister which has less than $80 \%$ fill height will clearly indicate this, but the DWPE proposes to take no further action if the 80 fill helght is not achieved.

The form for this record contains:

- The canister number.

- The glass height, determined from the neutron detector.

- The glass height, determined from the gamma detector.

\section{Heat Generation Rate}

The WAPS require that the DWPE report, in the Prodliction Records, the heat generation rate for the canistered waste itorms at time of production. The heat generation rate will be calculated from the radionuclide content of the glass, using standard values of the thermal output per unit activity for each radionuclide. The radionuclides which will be included in performing this calculation will be all of those radionuclides to be reported to the repository as part of the radionuclide inventory, and all radionuclides analyzed for process control purposes in the DWPE' 


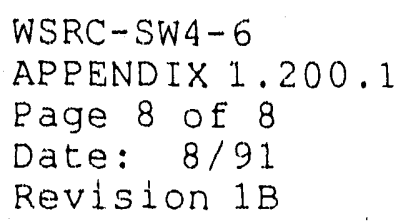

TABLE 1.200.1.1 Content of DWPE Production Records

\section{Specification Information in the Production Records}

1. 1.2

1.2 .2

1.3

2.1

2.2

2.3

$3.1,3.9$

3.5

3.7 .2

3.11
Elemental composition of glass (For all elements > 0.5 wto of glass)

Estimates of radionuclide inventory (For all radionuclides with $\tau_{1 / 2}>10 \mathrm{yr}$ and $>0.01$ of of $\mathrm{Cl}$ for times between 0 and 1100 years)

Predicted PCT results based on chemical analyses, and results of product Consistency Test from glass samples

Canister procurement documents

Closure weld parameters

Identification of canisters

Leak test result on Inner Canister Closure

Eill level from gamma and neutron measurements

Heat generation rate

Wall thickness of canister 
WSRC - SW $4-6$

APPENDIX 1.200 .2

Page 1 of 6

Date: $8 / 91$

Revision $B$

DESCRIPTION

OE THE SHIPPING AND STORAGE RECORDS EOR

DWPE CANISTERED WASTE EORMS 
WSRC - SW $4-6$

APPENDIX 1.200 .2

Page 2 of 6

Date: $8 / 91$

Revision $B$

APPENDIX 1.200 .2

Description of the DWPF Shipping and Storage Records

\section{INTRODUCTION}

The Department of Energy's Office of Civilian Radioactive Waste Management has established specifications the DWPF product must meet to be acceptable for disposal at a repository. These Waste Acceptance Preliminary Specifications (WAPS) require that the DWPF provide evidence of compliance with the WAPS at time of shipment. This evidence is to be documented, and sent to the repository, in the form of Shipping and Storage Records for DWPF canistered waste forms. In this Appendix, the content of the shipping and Storage Records is detailed, based on the WAPS and the waste Acceptance Process activities described in the DWPE Waste Form Compliance Plan.

\section{CONTENT}

The Shipping and Storage Records summarize the storage history of DWPF canistered waste form after production, and contain information necessary for shipment. The DWPE will provide the Shipping and Storage Records to the repository operator at time of shipment of the canistered waste forms. Because it is unlikely that this will occur before the year 2008, a shipplng facility to accomplish many of the actions described in this Appendix has not yet been designed. Such a facility will undoubtedly contain a smear test station, equipment to measure the weight and dimensions of canistered waste forms, instruments to measure the dose rate of the coming from the canistered waste form, and other equipment necessary to satisfy whatever specifications are in existence at that time.

The information to be reported is summarized in Table 1.200.2.1. Any actions to be taken based on the information are also identified.

\section{Identification and Labelding}

The Shipping and Storage Records will identify particular canisters by the code on the label afflxed to the canister. This code, unique to each canister, will be the key to tracing the records for each canistered waste form.

\section{Timing}

The Shipping and storage Records will be provided by the DWPF to the repository operator, prior to shipment of canisters. The 
WSRC-SW4-6

APPENDIX 1.200 .2

Page 3 of 6

Date: $8 / 91$

Revision $B$

Shipping and storage Records will be treated by the DWPE as 1 ifetime quality records.

Rhase Stability

The Shipping and Storage Record for each canistered waste form will certify that the maximum waste glass temperature experienced during storage of each canistered waste form is at least $100^{\circ} \mathrm{C}$ below the transition temperature. The Shipping and storage Record for each canistered waste form will also certify that after initial cooldown, no unusual events occurred which would cause the maximum temperature of the canistered waste form to exceed the specified temperature $\left(\sim 340^{\circ} \mathrm{C}\right)$, during handling and storage at the DWPE. After filling, the canister will be held in the Melt cell until it cools below $100^{\circ} \mathrm{C}$ (thus, unless some thermal excursion occurs, the canister temperature must be less than $100^{\circ} \mathrm{C}$ at time of shipment). After the canister is transferred to the Canister Decontamination Cel.1, it can exceed the specified temperature $\left(\sim 340^{\circ} \mathrm{C}\right)$ in only two ways:

- The heat generation rate of the glass is too high, so that heat buildup occurs during storage. The heat generation rate of the glass will be calculated from the radionuclide inventory (see below). Calculations using the design of the interim Glass Waste Storage Building (GWSB) and the projected heat generation rates will be used to show that the specified temperature $\left(\sim 340^{\circ} \mathrm{C}\right)$ will not be excended. Although detalled calculations have not yet been performed, they are expected to show that canisters of waste glass which comply with the heat generation rate specification also comply with this specification. These detailed calculations will be included in the Waste Form Qualification Report.

- An unexpected high temperature event, such as a fire in the interim GWSB, has exposed the glass to high temperatures. The temperature control on the forced air cooling system in the GWSB will provide the data upon which certification is to be based. This data will be taken for the entire period for which the canistered waste forms are stored.

If a high temperature is detected in the GWSB exhaust air, a written record will be generated which includes:

- Date(s) and duration of excursion.

- The maximum temperature reached. 
WSRC-SW4-6

APPENDIX 1.200 .2

Page 4 of 6

Date: $8 / 91$.

Revision $B$

- The canisters contained in the GWSB during the excursion.

- A statement that these canisters are potentially nonconforming items.

This record will be included in the Storage and Shipping Records.

If such a condition occurs, an investigation of the incident will be documented, and the canisters will be dispositioned as de-. scribed in Part 6, Item 800 of the WCP. The disposition will also be included in the shipping and Storage Records.

\section{Remeral of Canister contamination}

The WAPS require that the DWPF provide evidence of removal of contamination in the Shipping and storage Records. The DWPF will report the smear test results for each canister. If the level of contamination exceeds 220 alpha $\mathrm{dpm} / 100 \mathrm{~cm}^{2}$, or 2200 beta or gamma $\mathrm{dpm} / 100 \mathrm{~cm}^{2}$, the canister will be decontaminated again, before it is placed in the cask. In this case, the results of a confirmatory smear test will also be reported.

If the canister contamination level cannot be brought down to the specifled values, then the canister will be identified as a nonconforming item, and dispositioned according to the procedure outlined in Part 6, Item 800, of the Waste Eorm Compliance Plan.

The record will include the results of smear tests from the shipplng facility, and identification of tester(s).

\section{Gamma and Neutron Dose Rates}

The WAPS require that the DWPF report, in the shipping and Storage Records, the gamma and neutron dose rates for the canistered waste forms, at time of shipment. At time of shipment, these will be measured in the DWPE shipping facility.

If the calculated dose rates exceed $10^{5} \mathrm{rem} / \mathrm{hr}$ surface gamma dose rate, or $10 \mathrm{rem} / \mathrm{hr}$ neutron dose rate, then the canister will be identified as a nonconforming item, and dispositioned according to the procedure out lined in Part 6, Item 800, of the Waste Form Compliance plan. 
WSRC-SW4- 6

APRENDIX 1.200 .2

Page 5 of 6

Date: $8 / 91$

Revision $\mathrm{B}$

Welght, Length, Dlameter, and overali Rimensions

The WAPS require that the DWPE report the welght, length, and diameter of each glass-filied canister in the shipping and storage Records. The DWPE must also certify that the canister will fit without forcing into a shipping cask. The weight will be measured prior to shipment, and the welght and the estimated error of the measurement reported. The diameter and length w11.1 also be measured in the shipping facility, and reported. Methods to certify the canister will fit without forcing into a cask have not yet been developed, but will probably involve use of a ring gauge. 
WSRC-SW4-6

APPENDIX 1.200 .2

Page 6 of 6

Date: $8 / 91$

Revision $B$

TABLE 1.200.2.1 Content of DWPE Shipping and Storage Records Spectelcation Information to the Shtpping and storage Records

1.4 Certification that waste form kept below $340^{\circ} \mathrm{C}$

3.6

Results of smear tests performed in the shipping factlity

3.8 .2

$\gamma$, n dose rates

3.11

Weight of filled canister, and estimated error

3.11

Diameter, length of canlstered waste form

3.11

Certify that canister fits without forcing into cask 
WSRC-SW4-6

APPENDIX 1.200 .3

Page 1 of 4

Date: $8 / 91$

Revision 1B

SUMMARY

DWPE QUALIEICATION RUNS ACTIVITIES 
WSRC $-S W 4-6$

APPENDIX 1.200 .3

Page 2 of 4

Date: $8 / 91$

Revision $1 . B$

APPENDIX 1.200.2 Summary of DWPE Integrated Cold Run Activities Relevant to the Waste Acceptance Process

\section{QBJECTIVES}

The objectives of the DWEE Startup Test Program are to accomplish the following:

- To demonstrate the overall functionality of the DWPE process and 1 ts auxiliary faclittles using synthetic feeds so that operating conditions and procedural requirements can be adequately demonstrated prior to beginning radioactive operations.

- To perform tests required by the Waste Eorm Compliance Plan (WCP) wh1ch demonstrate that the DWPE process and product control are adequate to satisfy the requitrements of the waste Acceptance Preliminary Specifications (WAPS).

A major portion of the Startup Test Program deals with production of simulated cantstered waste forms in prototyplc manner, to demonstrate, in particular, control of the vitrification process. The campalgns in the facility during which this will be accomplished are called the Qualification Runs. The activities which will be performed as part of the Qualification Runs are described in this Appendix.

\section{QUALIEICATIQNRUNS}

The sections below describe specific tests which will be performed during the Startup Test Program for inclusion in the waste Form Qualification Report. In addition, most of the routine measurements and proceduces which will be performed during radioactive operations and included in the production Records will also be performed during this time. At the present time, there is no intent to report on these activities, so they w111 not be discussed further here.

\section{Whemical Composition During Production (Specification 1.1.2)}

The objective of this test is to confirm the mathematical relationship used to predict the glass product composition from the process batch composition. In order to achieve this objective, the DWPE w11l have to demonstrate that 1t can reliably sample and analyze melter feed materlals. As part of this demonstration, the precision and accuracy of the methods which will be used to determine glass composition will be established. This will be accomplished by determining the composition of samples of glass from each cantster fllied, and by analyzing each process batch on the 
WSRC-SW4-6

APPENDIX 1.200 .3

Page 3 of 4

Date: $8 / 91$

Revision $1 B$

same frequency (see Part 3, Item 200) as will be used $1 \mathrm{n}$ the DWPF. These results will also be lised to estimate the error associated with treating the transition period between macro-batches as a step change in composition.

The initial charge to the melter will be a glass frit specially formulated for melter startup. After building the melter level to the operating level and achieving stable meltef operation, the Qualification Runs will begin. These campaigns will be sludge/ precipitate runs with (in order of performance)

a) a ronradioactive doped composition to simulate variations around the composite feed $(20$ canisters produced, corresponding to 5 melter turnovers),

b) a high viscosity (high aluminum) composition to simulate an extreme change in feed composition (20 cantsters produced, corresponding to 5 melter turnovers),

c) a low viscosity (high iron) composition to simulate another extreme change ir feed composition (20 canlsters produced, corresponding to 5 melter turnovers), and

d) composite feed to simulate return to standard operation from low viscosity $(20$ canisters produced, corresponding to 5 melter turnovers).

At least one of these runs will require addition of supplemental chemicals to demonstrate that the feed composition can be adfusted, if required. Approximately 75,000 pounds of glass will be made during each of these tests to provide at least a 958 changeover of melter composition, assuming that the melter behaves 11 ke a well-stirred tank.

\section{Preduct conststency (Specification 1.3).}

Since chemical composition is the most important cieterminant of glass durability, analysis and testing (using the DWPE Product Consistency Test - PCT) of glass samples from each canister pro-duced will be used to demonstrate that the approach to meeting specification 1.3 (Part 3, Item 500) actually provides a product which satisfles the specification, with sufficient reliability to meet the statistical criterion of the specification. The canisters produced during the Qualification Runs will also be sectioned, and the sections sampled. Any crystalline phases present 
WSRC-SW $4-6$

APEENDIX 1.200 .3

Page 4 of 4

Date: $8 / 91$

Revision $1 B$

will be identified and their content determined, and the behavior of samples taken with the DWPE glass sampler compared to samples of glass taken from the sectioned canisters.

Chemical and phase stakil is (specification 1.4)

Cooldown profiles for the canisters obtained during pilot-scale testing will be verified under typical production conditions to satisfy this specification. In addition, the effect on the thermal profile of placing a canister in the Melt cell Insulated storage Rack will be evaluated. Special instrumented canisters will be designed and procured to perform these tests.

Eabrication and closure (specification 2.21.

Confirmation of the parametric weld study using the DWPF welder will be performed. Initial runs will be made on dummy heads, and will span the entire operating range. Then full-scale cianisters will be used to demonstrate actual operation. The repair cap weld procedure will also be demonstrated. The quality of the welds produced will be verified by metallurgical characterization, and physical testing.

Eree Liquids and erganics (Specification 3.2, 3.31)

Tests will be performed to confirm that the Inner Canister closure, when installed under typical operating conditions, prevents intrusion of water, particularly from the canister decontamination operation. This test will require canister modification to permit physical examination of the void volume of the canister for moisture and organics.

Eree Gases and Pressure (specification 3.21

Tests will be performed to demonstrate that canistered waste forms will not contain prohibited gases, and will be below 22 psia after cooling.

\section{Eil1 Ievel Specification 3.51}

Confirmation of an operable level detection system is required to demonstrate control of the fill level in the canister (desired minimum fill is $80 \%$ ). The DWPE will demonstrate the neutron transmission method for canister level determination during the Qualification Runs. 

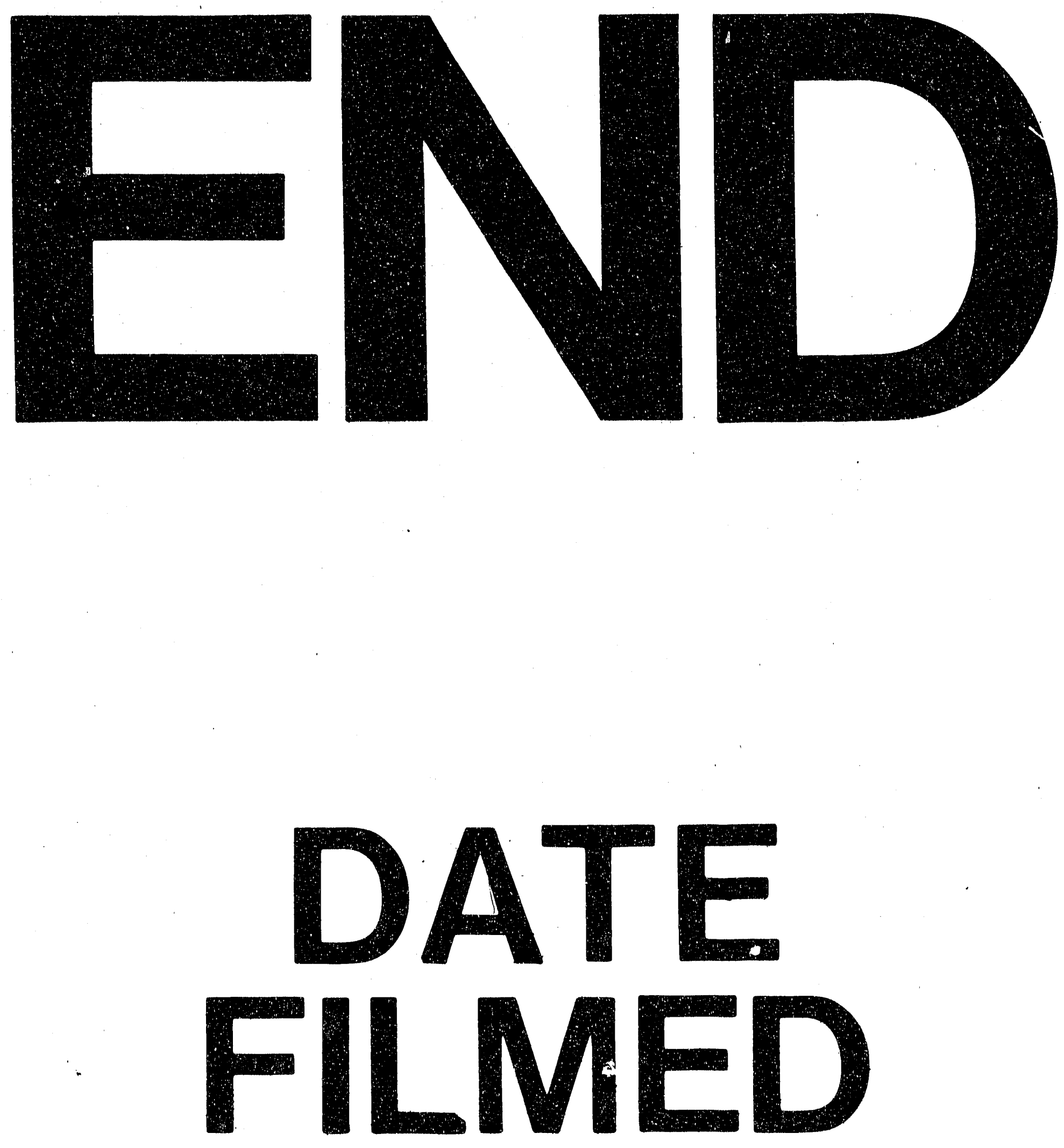

$f$

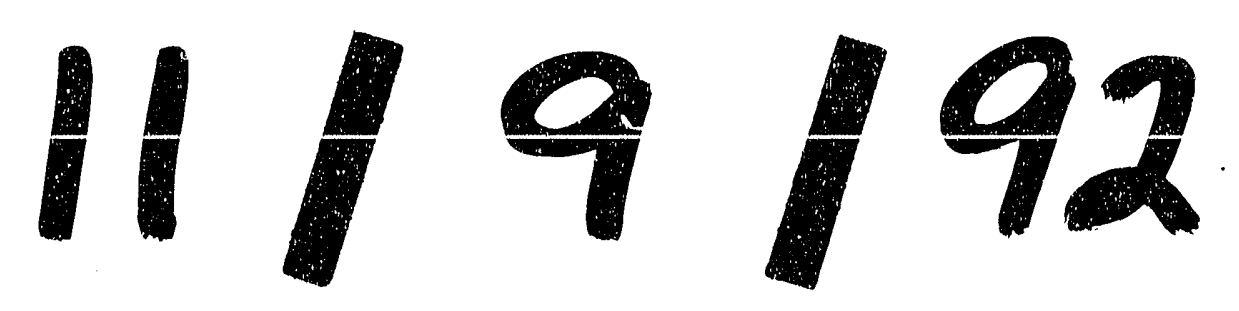


